\title{
Effect of Feedstock Moisture Content on Biomass Boiler Operation
}

\author{
by \\ Nazanin Abbas Nejad Orang
}

A thesis submitted in conformity with the requirements

for the degree of Masters of Applied Science

Chemical Engineering and Applied Chemistry

University of Toronto

(C) Copyright by Nazanin Abbas Nejad Orang 2014 


\title{
Effect of Feedstock Moisture Content on Biomass Boiler Operation
}

\author{
Nazanin Abbas Nejad Orang \\ Masters of Applied Science \\ Chemical Engineering and Applied Chemistry \\ University of Toronto \\ 2014
}

\section{Abstract}

Burning feedstock with high and constantly varying moisture contents is a challenge in the operation of the stoker-grate type biomass boiler in pulp and paper mills. A fundamental two part study was performed to systematically investigate the effect of moisture content on the combustion behaviour of woody biomass. The first part involved a thermogravimetric combustor controlled at different temperatures, and the second part involved collecting and analyzing operating data of 3 biomass boilers. The laboratory results show that combustion occurs through three stages: time-to-ignition, volatile burning, and char burning and samples containing $40 \%$ moisture ignite and burn readily at $800^{\circ} \mathrm{C}$, but they take longer to ignite at lower temperatures and do not ignite at $400^{\circ} \mathrm{C}$. For the field studies, the moisture content of the feedstock was back calculated by a material and energy balance. The relationship between moisture content and the other operating data was studied. The results suggest that changes in moisture content mainly affect the lower furnace temperature and excess $\mathrm{O}_{2}$. 


\section{Acknowledgements}

I would like to thank my supervisor, Prof. Honghi Tran for his outstanding guidance and mentorship which has given me an exceptional perspective in my professional and personal development. He has taught me to realize my own potentials and helped me in using them to the fullest extent.

This work was conducted as part of the research program on "Increasing Energy and Chemical Recovery Efficiency in the Kraft Process - III", jointly supported by the Natural Sciences and Engineering Research Council of Canada (NSERC) and a consortium of the following companies: Andritz, AV Nackawic, Babcock \& Wilcox, Boise, Carter Holt Harvey, Celulose Nipo-Brasileira, Clyde-Bergemann, DMI Peace River Pulp, Eldorado, ERCO Worldwide, Fibria, FP Innovations, International Paper, Irving Pulp \& Paper, Kiln Flame Systems, Klabin, MeadWestvaco, StoraEnso Research, Suzano, Tembec, Tolko Industries and Valmet. I would like to thank the consortium members for their financial support as well as valuable discussions and information regarding the operation of biomass boilers specific to this work. I would like to thank Don McCabe of Irving Pulp and Paper, Moise Dion of DMI Peace River Pulp and Warren Blackmore of $\mathrm{CHH}$ Kinleith for their contribution to the field studies.

I would like to extent my gratitude to my friends and colleagues whom I worked with in the last two years in our research group specially Masoumeh, Sara, Liming, Carolyn, Eric, Atif, Wei and Sue. Without their support and friendship the completion of this work would have been much more difficult.

I wish to thank my parents, Maryam and Samad, for setting the best example of success and happiness and for their unconditional love and support as well as my brother Nima for his sincere friendship and support.

Finally, I would like to thank my best friend and husband, Navid who always believed in me more than I believed in myself and for teaching me to be and want the best and for always making me feel loved and blessed. This thesis is dedicated to him and my parents. 


\section{Table of Contents}

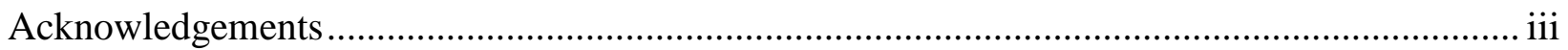

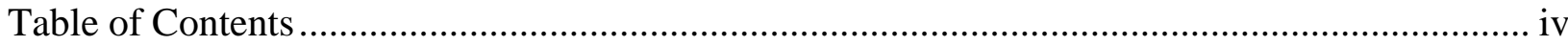

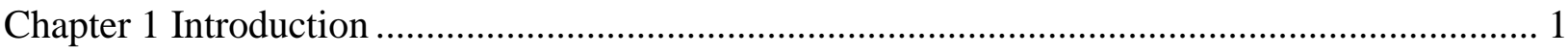

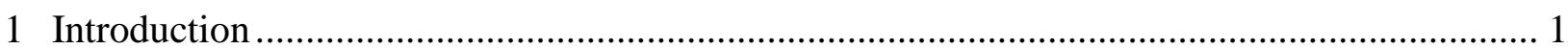

1.1 Energy Demand in the Pulp and Paper Industry ............................................................ 1

1.2 Biomass Boilers ………………………………….............................................. 2

1.2.1 Summary of Operation................................................................................... 2

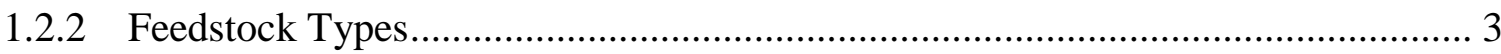

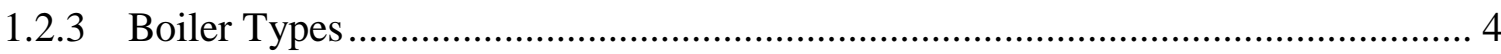

1.2.4 Thermal Performance................................................................................. 7

1.2.5 Operational Problems.................................................................................. 9

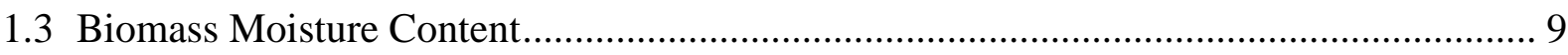

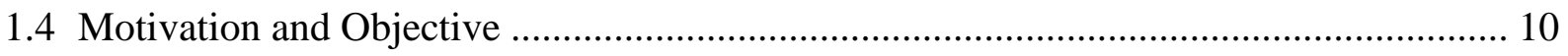

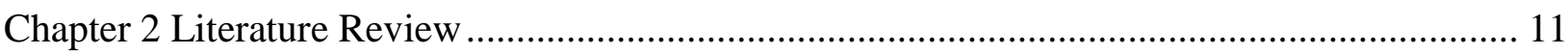

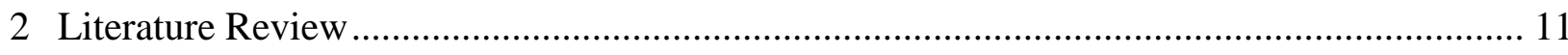

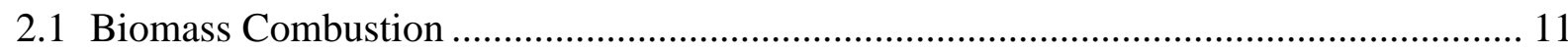

2.2 Combustion of High Moisture Content Material ........................................................... 12

2.3 Fixed Bed Combustion .............................................................................................. 13

2.4 Biomass Boilers in Pulp and Paper Mills ………………............................................ 14

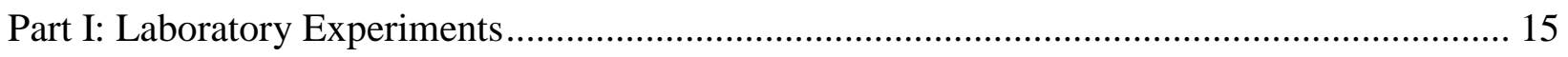

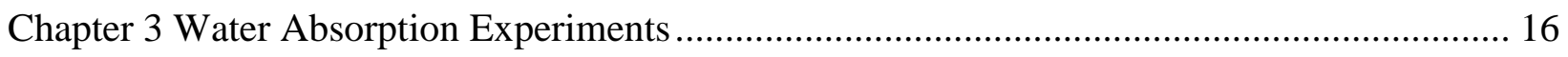

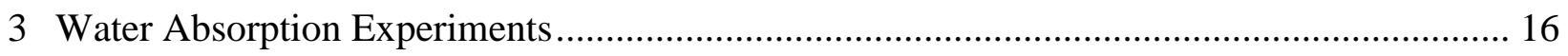

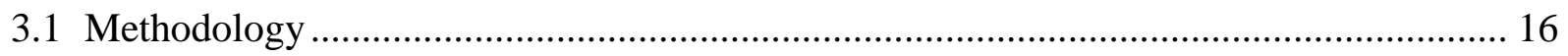

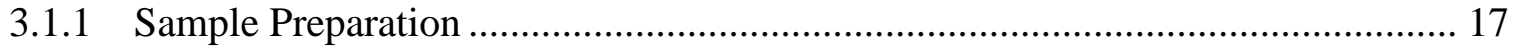

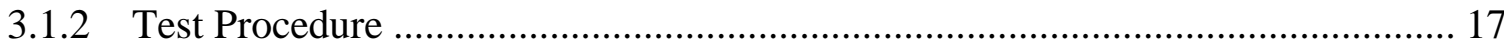




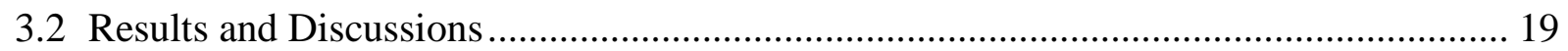

3.2.1 Water Absorption and Wood Orientation ............................................................. 19

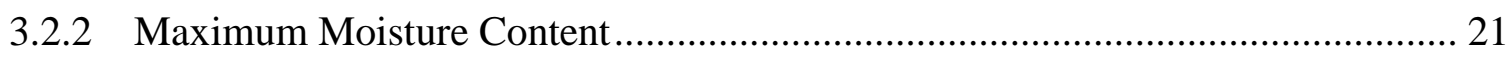

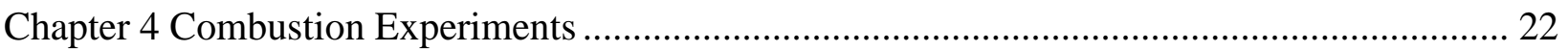

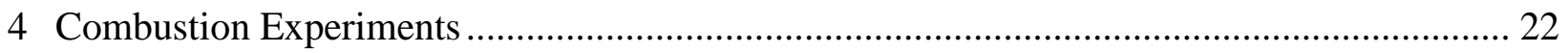

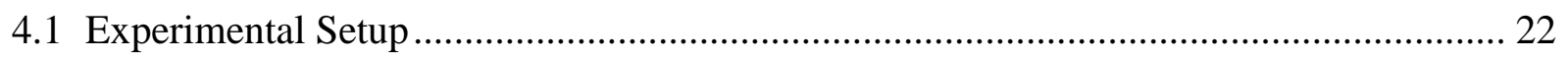

4.1.1 Thermogravimetric Combustor..................................................................... 22

4.1.2 Sample Preparation .................................................................................... 24

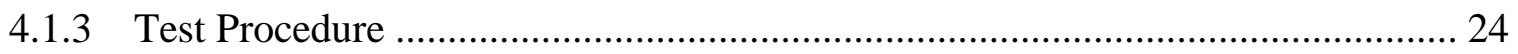

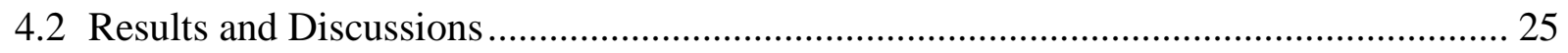

4.2.1 Combustion Behaviour ……………………………………………………... 25

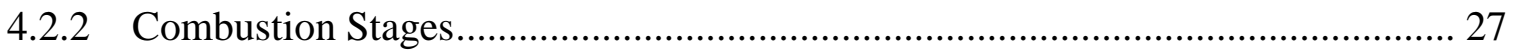

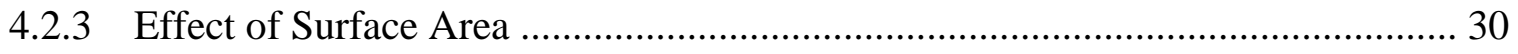

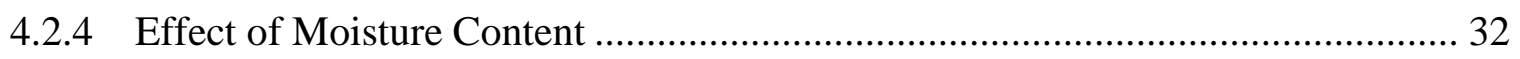

4.2.5 Water Vapor Exit during Combustion ............................................................. 37

4.2.6 Effect of Furnace Temperature …………………………............................ 40

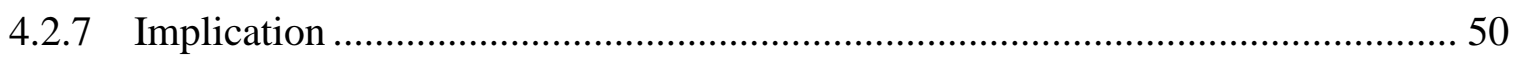

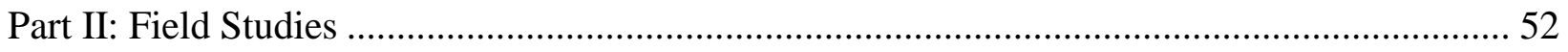

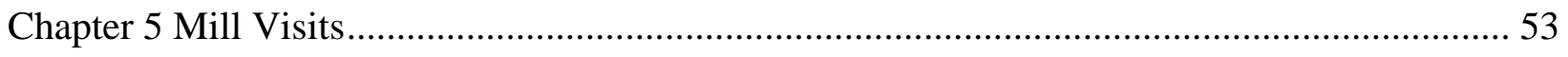

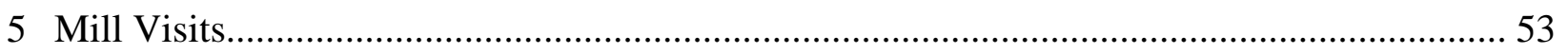

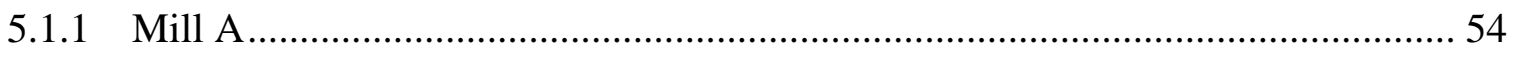

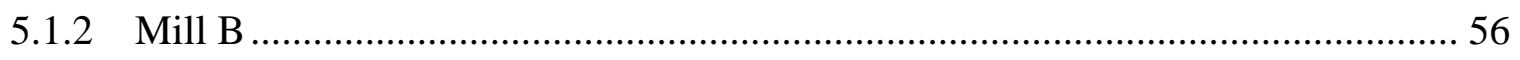

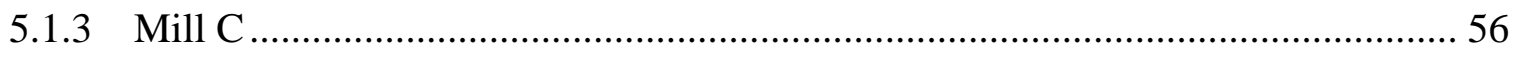

5.1.4 Total Heat Release Calculations …………………......................................... 56

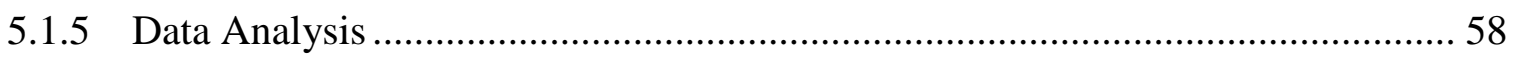

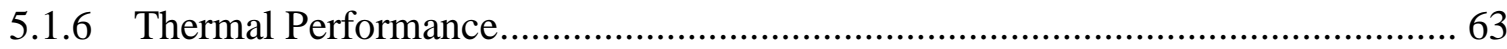




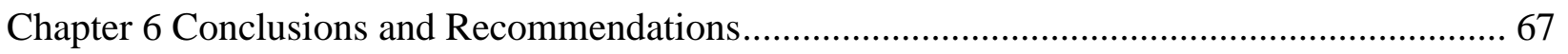

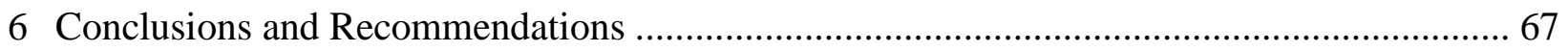

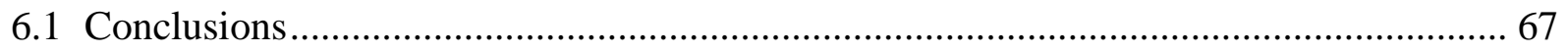

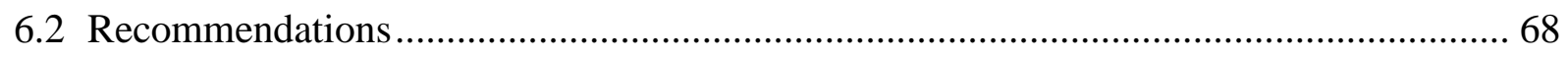

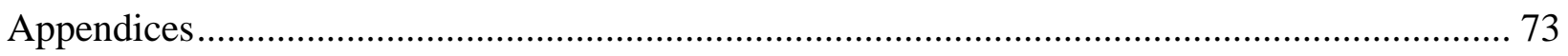

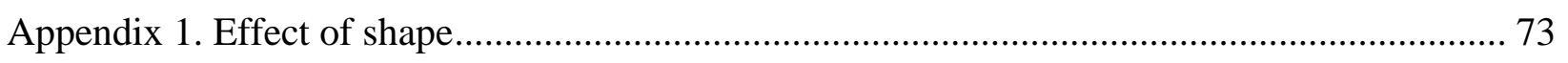

Appendix 2. Effect of moisture content and wood species........................................................ 76

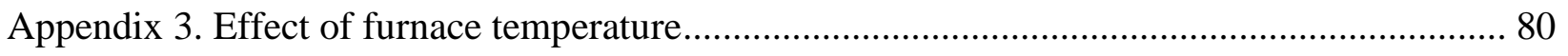

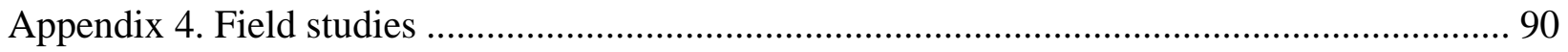

\section{List of Figures}

Figure 1. Overview of pulp making process. (Courtesy: Valmet) …………………………...... 1

Figure 2. Schematic diagram of a biomass boiler (Courtesy: Babcock \& Wilcox)......................... 3

Figure 3. Stoker grate type boiler (Courtesy: Babcock \& Wilcox) ……………………............. 5

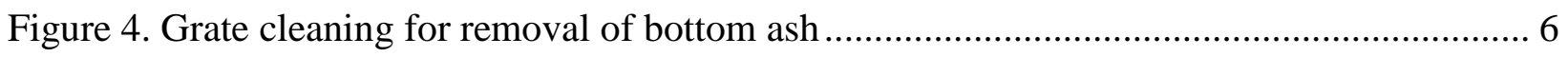

Figure 5. Bubbling fluidized bed type boiler (Courtesy: Babcock \&Wilcox) …………................ 7

Figure 6. Different types of feedstock a) conveyor belt to boiler, b) sludge, c) older biomass pile wetted by rain and d) fairly dry biomass pile …………........................................................... 8

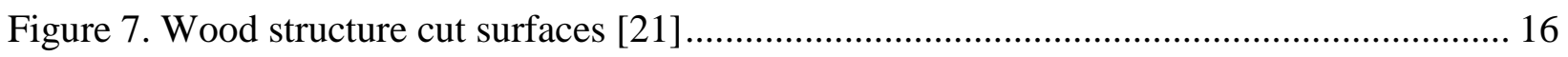

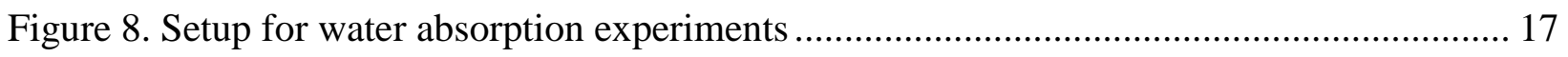

Figure 9. Water absorption experiment a) cedar sample with all surfaces covered except for radial surface b) radial surface of cedar sample inserted in water 
Figure 10. Water absorption for softwood (cedar).

Figure 11. Water absorption for hardwood (maple) 20

Figure 12. a) Thermogravimetric (TG) combustor and b) Cross section of the electrical furnace 23

Figure 13. Combustion of a $1.34 \mathrm{~g}$ oak sample with $20 \%$ moisture content at $800^{\circ} \mathrm{C}$ (time

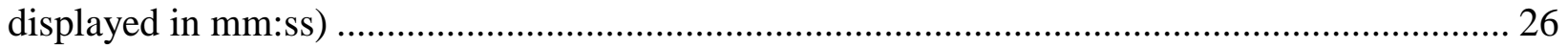

Figure 14. Combustion stages of biomass samples $(1.5 \mathrm{~cm} \times 1.2 \mathrm{~cm} \times 1.2 \mathrm{~cm})$ burned at $800^{\circ} \mathrm{C} \ldots . .28$

Figure 15 . Weight change profile for combustion of oak at $800^{\circ} \mathrm{C}(1.34 \mathrm{~g}$ dry sample, $40 \%$ moisture content) 29

Figure 16. Combustion of poplar at $800^{\circ} \mathrm{C}$ 31

Figure 17. Combustion stages for poplar during combustion at $800^{\circ} \mathrm{C}$ 32

Figure 18. Effect of moisture content on the weight change profiles of pine during combustion at $800^{\circ} \mathrm{C}$. (All samples have an initial dry weight of $0.8 \mathrm{~g}$ ). 33

Figure 19. Combustion stages for pine during combustion at $800^{\circ} \mathrm{C}$ 34

Figure 20. Weight change profile for saw dust combustion at $800^{\circ} \mathrm{C}(0.2 \mathrm{~g}$ dry sample $) \ldots \ldots \ldots . . . .36$

Figure 21. Combustion stages for saw dust combustion at $800^{\circ} \mathrm{C}(0.2 \mathrm{~g}$ dry sample $)$............... 37

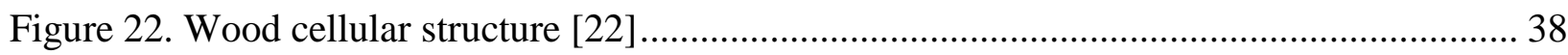

Figure 23. Flame distribution of softwood and hardwood during volatile burning (Furnace

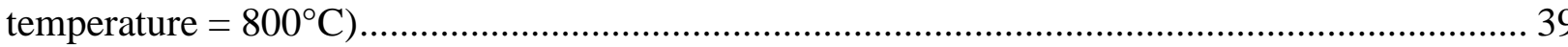

Figure 24. Effect of moisture content and furnace temperature on combustion of oak (1.34 g dry sample) 42

Figure 25. Weight profile for combustion of oak with $0 \%$ moisture content $(1.34 \mathrm{~g}$ dry) ........... 43

Figure 26. Weight profile for combustion of oak with $40 \%$ moisture content $(1.34 \mathrm{~g}$ dry) 43 
Figure 27. Combustion of freshly cut maple branch (30\% moisture content)......

Figure 28. Combustion of pine bark with $40 \%$ moisture content at $800{ }^{\circ} \mathrm{C}$ 46

Figure 29. Effect of moisture content and furnace temperature on combustion of pine bark (1g dry sample)

Figure 30. Weight profile for combustion of pine bark with $0 \%$ moisture content (1g dry)....... 49

Figure 31. Weight profile for combustion of pine bark with $40 \%$ moisture content (1g dry)...... 49

Figure 32. Spiral effect leading to boiler blackout ...................................................... 51

Figure 33. Mill visits a) Mill A and b) Mill B ............................................................... 53

Figure 34. Schematic diagram of biomass boiler at mill A …............................................ 55

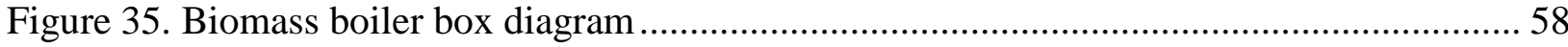

Figure 36. Changes of furnace temperature and moisture content with time .......................... 61

Figure 37. Changes of undergrate air flow rate and moisture content with time...................... 61

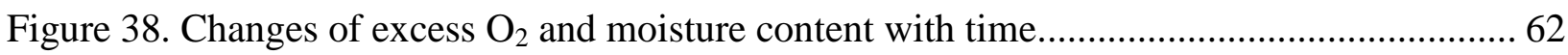

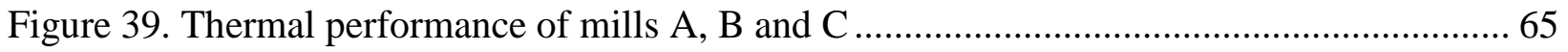

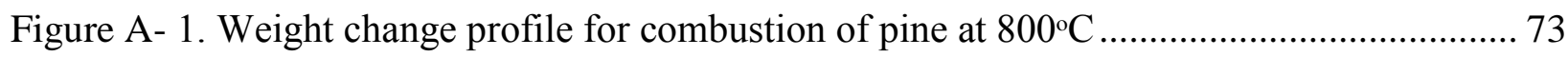

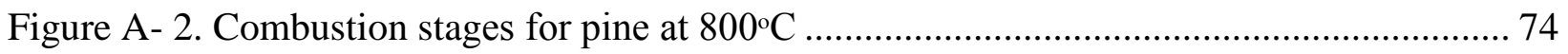

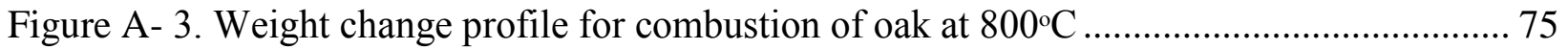

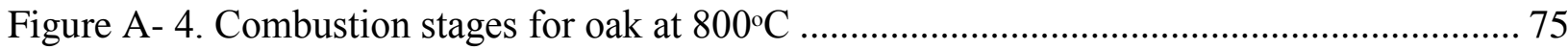

Figure A- 5. Weight change profile for combustion of cedar at $800^{\circ} \mathrm{C}(0.82 \mathrm{~g}$ dry weight $) \ldots \ldots . . .76$

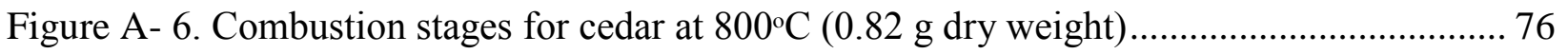


Figure A- 7. Weight change profile for combustion of poplar at $800^{\circ} \mathrm{C}(1.21 \mathrm{~g}$ dry weight $) \ldots \ldots . .77$

Figure A- 8. Combustion stages for poplar at $800^{\circ} \mathrm{C}(1.21 \mathrm{~g}$ dry weight $)$................................. 77

Figure A- 9. Weight change profile for combustion of oak at $800^{\circ} \mathrm{C}(1.34 \mathrm{~g}$ dry weight $) \ldots \ldots \ldots . . .78$

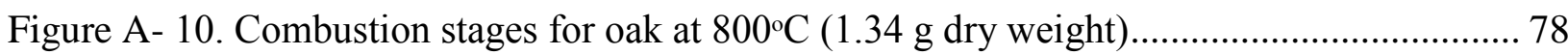

Figure A- 11. Weight change profile for combustion of maple at $800^{\circ} \mathrm{C}(1.75 \mathrm{~g}$ dry weight $) \ldots . .79$

Figure A- 12. Combustion stages for maple at $800^{\circ} \mathrm{C}$ (1.34g dry weight) .............................. 79

Figure A- 13. Weight change profile for combustion of oak at $800^{\circ} \mathrm{C}(1.34 \mathrm{~g}$ dry weight $) \ldots \ldots . . .80$

Figure A- 14. Weight change profile for combustion of oak at $750^{\circ} \mathrm{C}(1.34 \mathrm{~g}$ dry weight $) \ldots \ldots . . .80$

Figure A- 15 . Weight change profile for combustion of oak at $700^{\circ} \mathrm{C}(1.34 \mathrm{~g}$ dry weight $) \ldots \ldots . . .81$

Figure A- 16. Weight change profile for combustion of oak at $650^{\circ} \mathrm{C}(1.34 \mathrm{~g}$ dry weight $) \ldots \ldots . . .81$

Figure A- 17. Weight change profile for combustion of oak at $600^{\circ} \mathrm{C}(1.34 \mathrm{~g}$ dry weight $) \ldots \ldots . . .82$

Figure A- 18. Weight change profile for combustion of oak at $550^{\circ} \mathrm{C}(1.34 \mathrm{~g}$ dry weight $) \ldots \ldots . . .82$

Figure A- 19. Weight change profile for combustion of oak at $500^{\circ} \mathrm{C}(1.34 \mathrm{~g}$ dry weight $) \ldots \ldots . . .83$

Figure A- 20. Effect of furnace temperature and moisture content on time-to-ignition (1.34 g dry sample) 83

Figure A- 21. Effect of furnace temperature and moisture content on volatile burning time (1.34

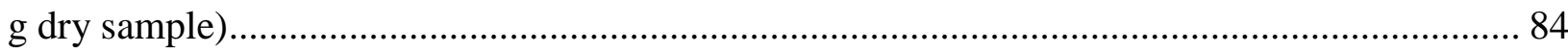

Figure A- 22. Effect of furnace temperature and moisture content on char burning time (1.34 g dry sample).

Figure A- 23. Combustion of oak with $0 \%$ moisture content at difference furnace temperatures (1.34 g dry sample) 
Figure A- 24. Combustion of oak with $40 \%$ moisture contenet at difference furnace temperatures (1.34 g dry sample) 90

Figure A- 25. Summary of material and energy balance 90

Figure A- 26.Changes of bark feed rate and moisture content with time for Mill A................. 95

Figure A- 27. Changes of outside air temperature and moisture content with time for Mill A.... 95

Figure A- 28. Changes of oil flow rate and moisture content with time for Mill A ................... 96

Figure A- 29. Changes of natural gas flow rate and moisture content with time for Mill A....... 96

Figure A- 30. Changes of windbox air damper control and moisture content with time for Mill A 97

Figure A- 31. Changes of north undergrate air and moisture content with time for Mill A........ 97

Figure A- 32. Changes of south undergrate air and moisture content with time for Mill A........ 98

Figure A- 33. Changes of arch air flow and moisture content with time for Mill A ................. 98

Figure A- 34. Changes of windswept air flow and moisture content with time for Mill A......... 99

Figure A- 35. Changes of burner air flow and moisture content with time for Mill A............... 99

Figure A- 36. Changes of total air flow and moisture content with time for Mill A ................ 100

Figure A- 37. Changes of tubular air heater outlet temperature and moisture content with time for

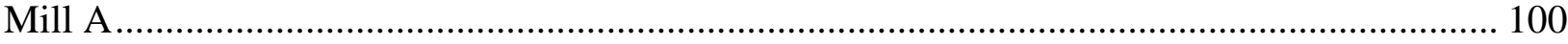

Figure A- 38. Changes of steam flow and moisture content with time for Mill A ................... 101

Figure A- 39. Changes of steam from bark and moisture content with time for Mill A ........... 101

Figure A- 40. Changes of steam from oil and moisture content with time for Mill A .............. 102

Figure A- 41. Changes of steam from natural gas and moisture content with time for Mill A .. 102 
Figure A-42. Changes of economizer inlet gas temperature and moisture content with time for Mill A 103

Figure A- 43. Changes of tubular air heater inlet gas temperature and moisture content with time for Mill A 103

Figure A- 44. Changes of ID fan outlet temperature and moisture content with time for Mill A 104

Figure A- 45. Changes of lower furnace temperature and moisture content with time for Mill A 104

Figure A- 46. Total precipitation and changes of moisture content with time for Mill A......... 105

Figure A- 47. Changes of incline amperage and moisture content with time for Mill A .......... 105

Figure A- 48. Verification of calculations by comparisong measured and calculated excess $\mathrm{O}_{2} 106$

\section{List of Tables}

Table 1. Maximum moisture content possible for different wood species up to 4 weeks of water

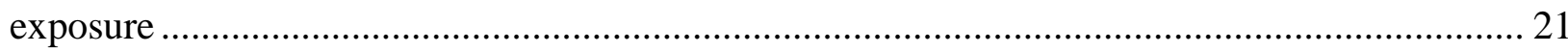

Table 2. Poplar sample sizes with different surface areas $(1.21 \mathrm{~g}$ dry sample) ......................... 30

Table 3. Combustion rate of different wood species ...................................................... 35

Table 4. Composition of pine bark and wood.............................................................. 45

Table 5. Effect of moisture content on net heat release from biomass combustion .................... 57

Table 6. Summary of input and output variables for one set of data for Mill A used to calculate

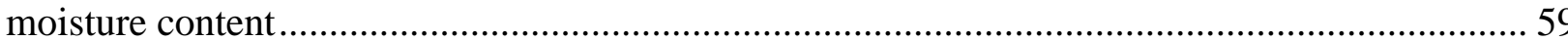

Table 7. Average values for operating parameters of mills A, B, and C ................................. 64 


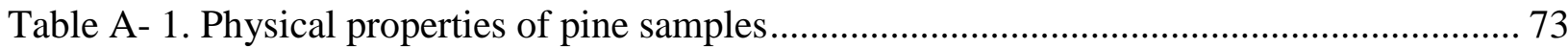

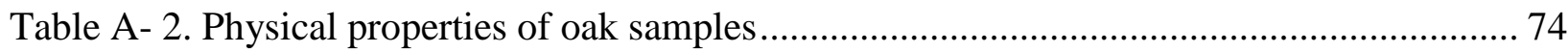

Table A- 3. Material balance for biomass combustion .............................................................. 91

Table A- 4. Calculations for amount of required oxygen and air .............................................. 91

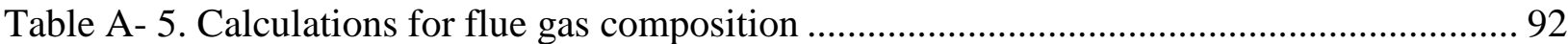

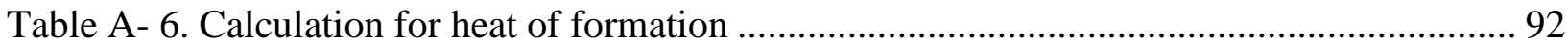

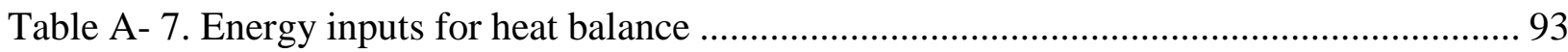

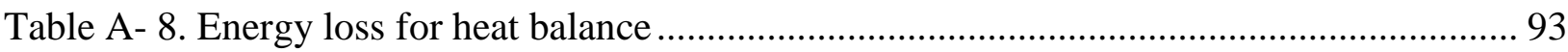

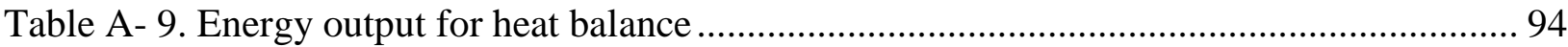




\section{Chapter 1 \\ Introduction}

\section{Introduction}

\subsection{Energy Demand in the Pulp and Paper Industry}

Pulp and paper mills require high pressure steam and electric power to dry pulp and paper products, heat water and process liquors, concentrate spent cooking liquor (black liquor), run equipment, and light and heat space and buildings. A typical pulp and paper mill needs 23 to 35 GJ of steam and 700 to $1000 \mathrm{KWH}$ of power per air dry metric ton (ADMT) of pulp produced. About 60 to $70 \%$ of the energy required is self-supplied by burning concentrated black liquor in recovery boilers. The remaining 30 to $40 \%$ is generated by burning biomass in biomass boilers, and by local utility stations. Natural gas and fuel oil are also co-fired in biomass boilers to supplement steam and power as required [1]. Biomass boilers provide pulp and paper mills with a means of addressing rising energy and waste disposal costs in order to remain competitive.

There is a need to maximize energy production while minimizing environmental impact in order to meet increasingly stringent regulations.

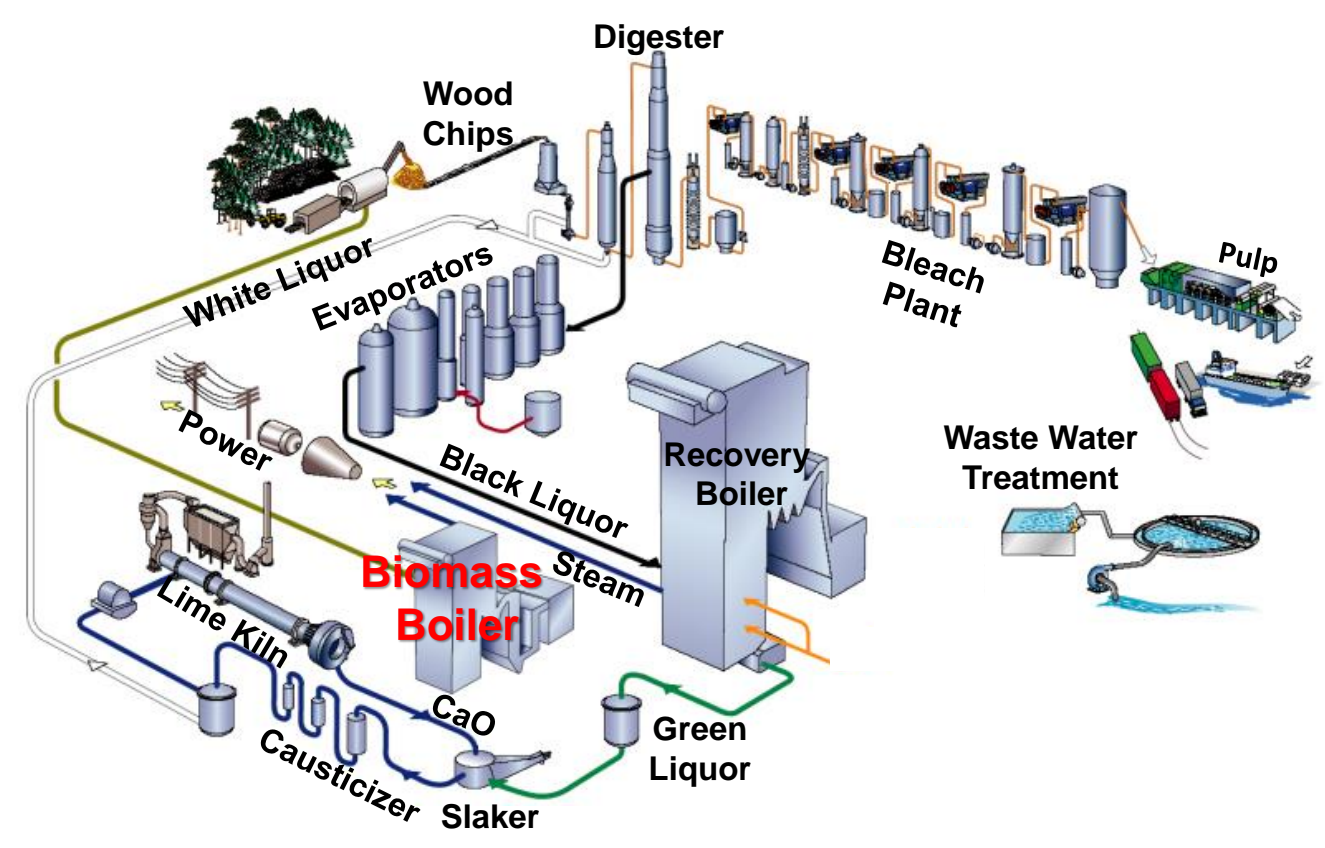

Figure 1. Overview of pulp making process. (Courtesy: Valmet) 


\subsection{Biomass Boilers}

\subsubsection{Summary of Operation}

Biomass boilers in pulp and paper mills are often referred to as hog-fuel boilers, bark boilers and power boilers. These boilers can be as large as an eight story tall building and depending on the design and type of boiler, they can produce up to $500 \mathrm{MW}$ of thermal energy [2]. Biomass is fed into the boiler together with excess air for complete combustion to occur. The high temperature lower furnace area is where combustion takes place. The heat released during combustion, heats up the flue gases in the boiler and the flue gases pass through banks of tubes in the super heater area of the boiler which is located at the top levels. The water in the tubes is heated and high pressure steam is produced and passed to the required stages of the process. The flue gases exit at the top of the boiler and are passed through heat exchangers or economizers to heat the inlet air of combustion. At this point, the flue gases have lost most of their heat and can be passed through electrostatic precipitators (ESP) in order for the fly ash and particulates to be captured in the ESP area. After that the flue gases, which are sufficiently cooled and do not contain any fly ash or particulate matter, exit via the stack. The pressure difference between the forced draft fan and the induced draft fan is kept at zero or slightly negative so that the boiler operates under a slight vacuum and the flue gases travel upwards and outwards in the boiler. Figure 2 shows a schematic diagram of a biomass boiler. 


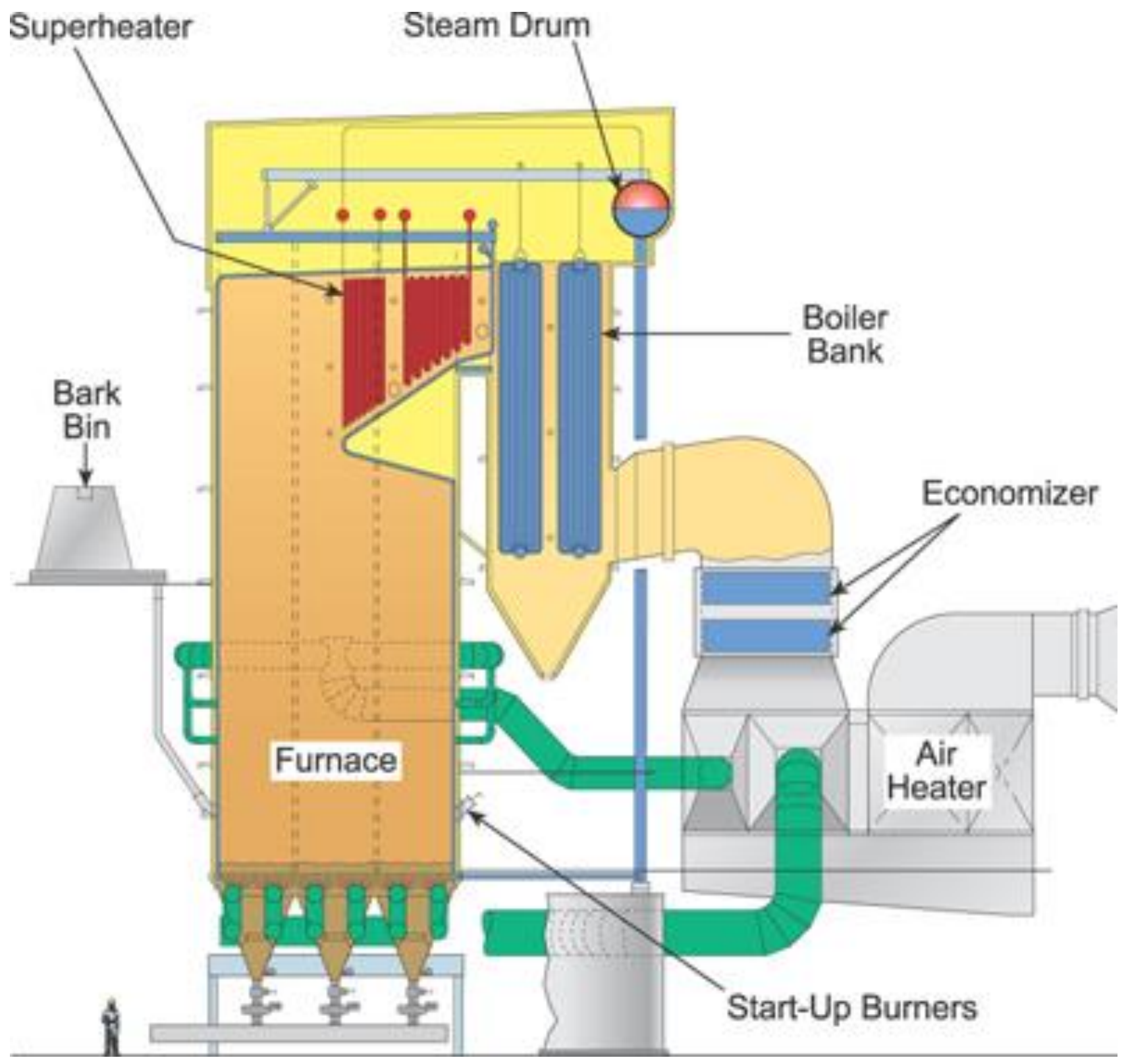

Figure 2. Schematic diagram of a biomass boiler (Courtesy: Babcock \& Wilcox)

\subsubsection{Feedstock Types}

The solid fuel that is burned in biomass boilers is known conventionally as hog-fuel, which is a mixture of various types of biomass available at the mill site, such as saw dust coming from the slasher deck, bark falling from the debarking drum, pins and fines from chip screening, wood residue from the wood yard, and rejects generated during chemical pulp treatment and recycled 
paper processing [3]. Many biomass boilers also burn primary sludge, secondary sludge (bio sludge) and/or deinking sludge generated from various mill processes.

While the main components of biomass on a dry basis are relatively constant, with $45-50 \mathrm{wt} \% \mathrm{C}$ (carbon), 5-6 wt\% $\mathrm{H}$ (hydrogen), and 40-44 wt\% O (oxygen), the moisture content, ash content and ash composition can vary widely, depending on sources and storage conditions of the feedstock. Bark, for instance, contains more ash, including more $\mathrm{Ca}$ (calcium) and $\mathrm{K}$ (potassium) than other parts of the tree. Agricultural residues (wheat/rice straw, corn waste, etc.) generally contain more ash, alkali, $\mathrm{Cl}$ (chlorine) and $\mathrm{S}$ (sulphur) than woody biomass. Rice husk contains a large amount of $\mathrm{Si}$ (silicon), while chicken litters contain $20 \mathrm{wt} \%$ ash and large amounts of $\mathrm{N}$ (nitrogen), P (phosphorus), K, and Ca.

\subsubsection{Boiler Types}

\subsubsection{Stoker Grate (SG) Boiler}

In stoker-grate (SG) boilers, shown in Figure 3, the biomass is fed into the boiler and piled on a grate and pile burning takes place. Combustion air is introduced from the bottom of the grate and travels through the pinholes to reach the biomass and combustion takes place on the bed. Stoker units are usually equipped with pinhole grates, vibrating grates, traveling grates, or reciprocating grates. If the grate is stationary, grate cleaning needs to take place once or twice daily, where the biomass on the grate is completely burned, and the bottom ash is removed from the grate manually as shown in Figure 4. The design of SG boilers dictates the acceptable properties of the feedstock. The thermal conversion efficiency of these types of boilers decreases significantly if the required properties of the feedstock are not met. The operating window is very narrow and needs to be followed strictly to avoid co-combustion of fossil fuels for a required steam production. 


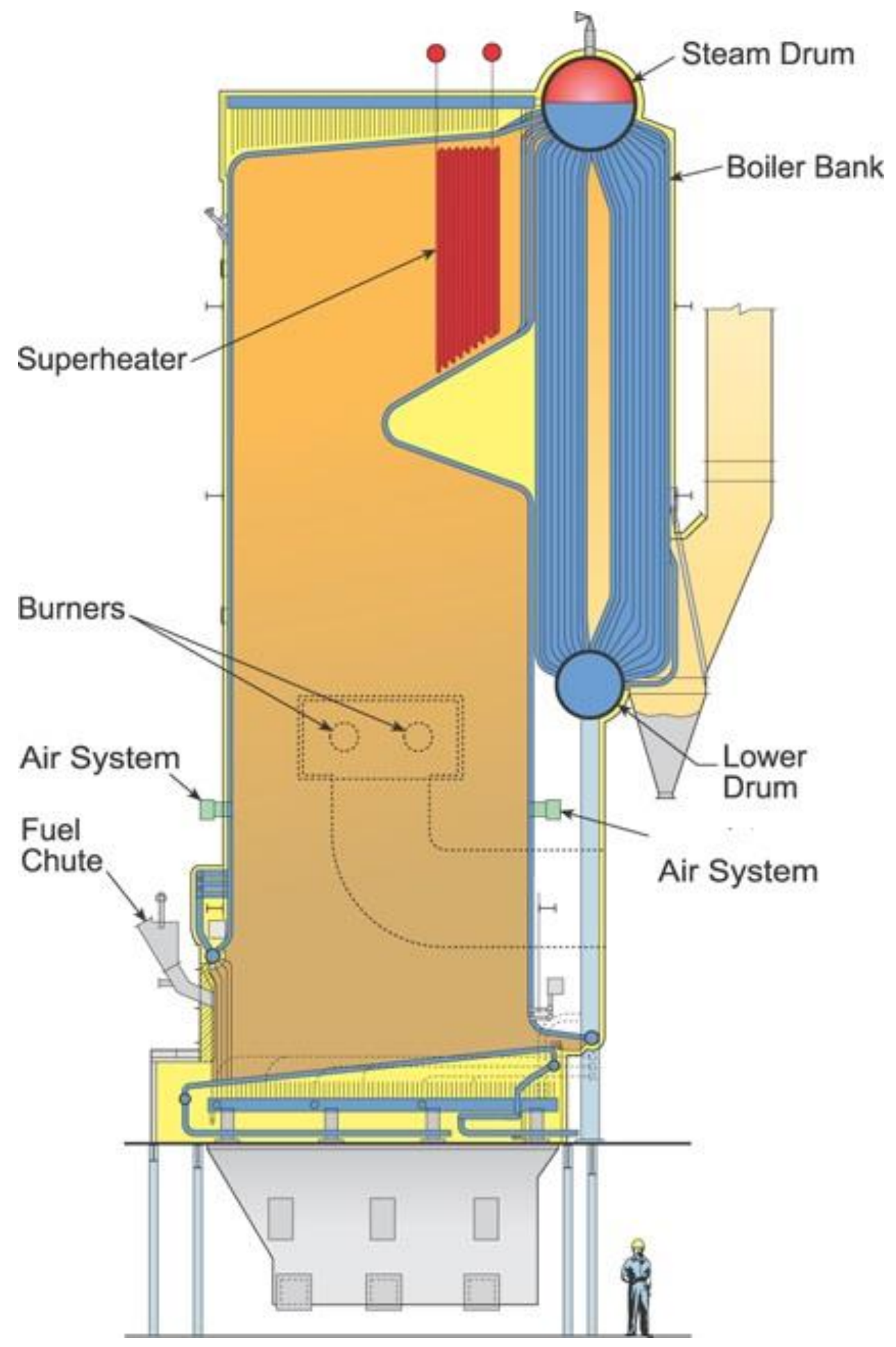

Figure 3. Stoker grate type boiler (Courtesy: Babcock \& Wilcox) 


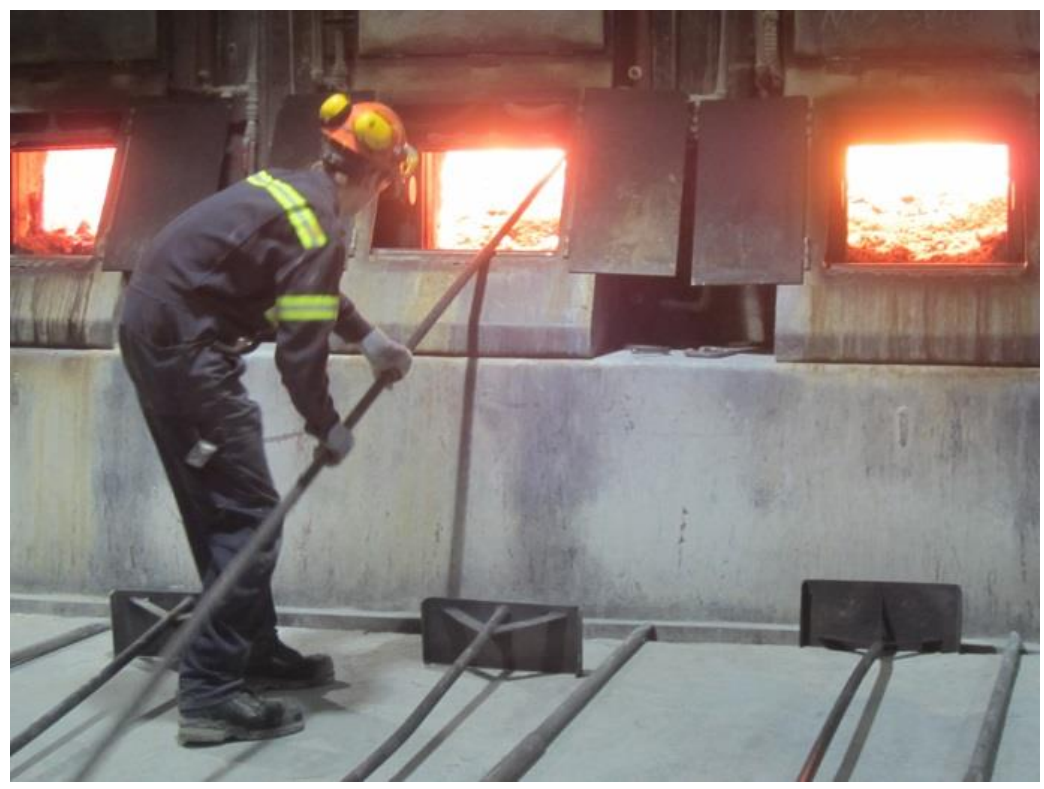

Figure 4. Grate cleaning for removal of bottom ash

\subsubsection{Bubbling Fluidized Bed (BFB) Boiler}

Bubbling fluidized bed (BFB) boilers are designed to increase the efficiency of combustion and be able to handle more variations in feedstock properties. In BFB boilers, shown in Figure 5, the biomass is fed in the boiler and mixed with the fluidizing medium, usually sand, and combustion takes place in flight. This way the heat transfer area increases with the use of the fluidizing medium and combustion takes place more efficiently. Also the air required for combustion is fed into the boiler in several locations: primary air at the bottom of the bed, secondary and tertiary higher up in the boiler respectively. The location where the secondary and tertiary combustion air is fed is where the combustion of volatiles takes place. BFB boilers can handle a wider variation in feedstock moisture content and size, and require less fossil fuel co-combustion to maintain the required steam pressure and flow. 


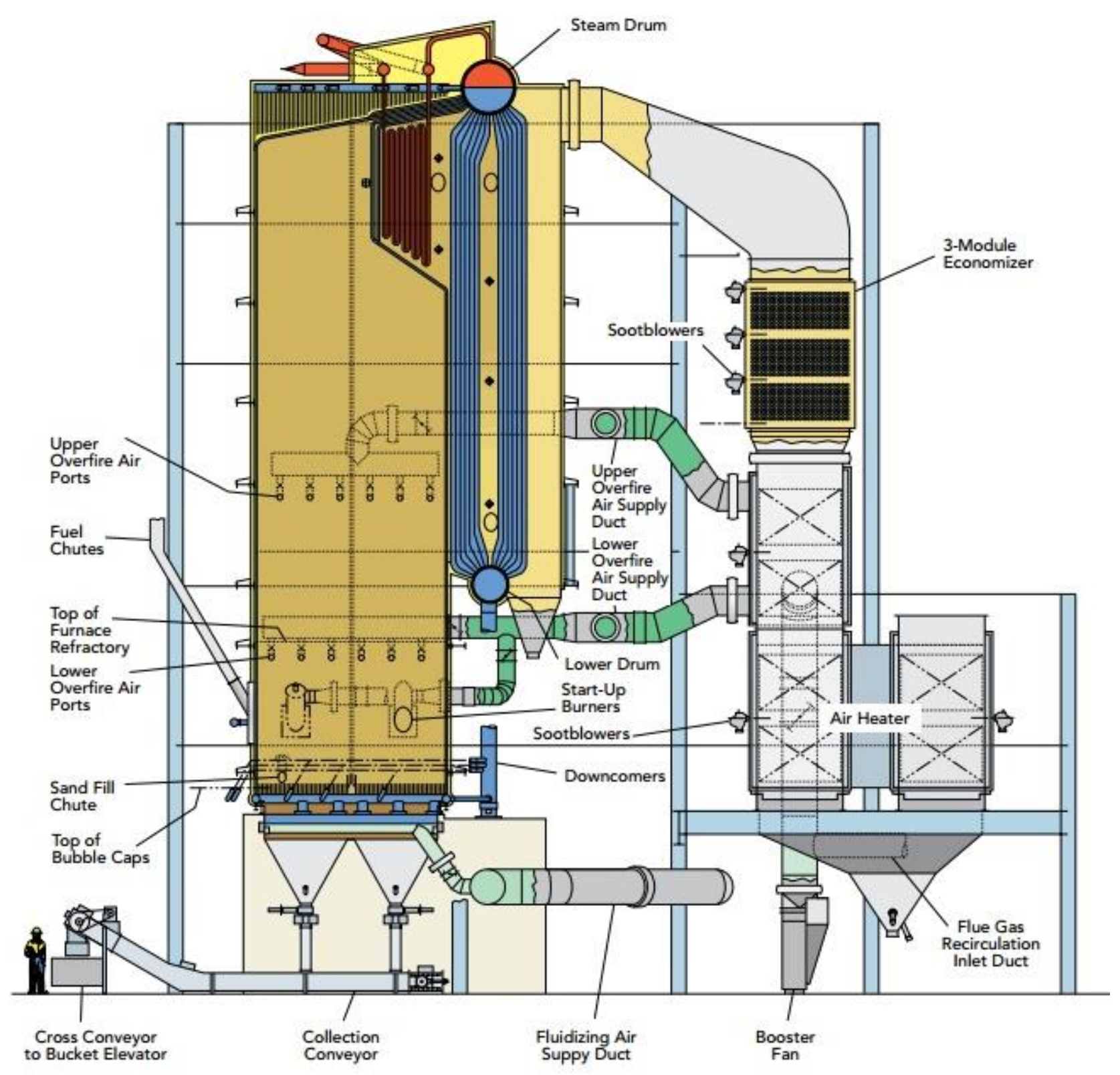

Figure 5. Bubbling fluidized bed type boiler (Courtesy: Babcock \&Wilcox)

\subsubsection{Thermal Performance}

A biomass boiler in pulp and paper mills typically converts about $75 \%$ of the combustion heat of its feedstock into steam and power. The thermal conversion efficiency of the boiler depends greatly on the moisture content, ash content and ash properties of the biomass, and on the design and operating conditions of the boiler [4]. Modern bubbling fluidized bed (BFB) boilers are generally more efficient and less susceptible to moisture variations than older stoker grate (SG) 
boilers [5]. For a given boiler, the boiler efficiency is dictated mainly by the moisture content and the combustion behavior of the feedstock, and the amount and thermal properties of the ash. Understanding the combustion behaviour of the feedstock is of vital importance for predicting the combustion efficiency since the characteristics of the feedstock can vary considerably in type, size, shape and moisture content as shown in Figure 6.

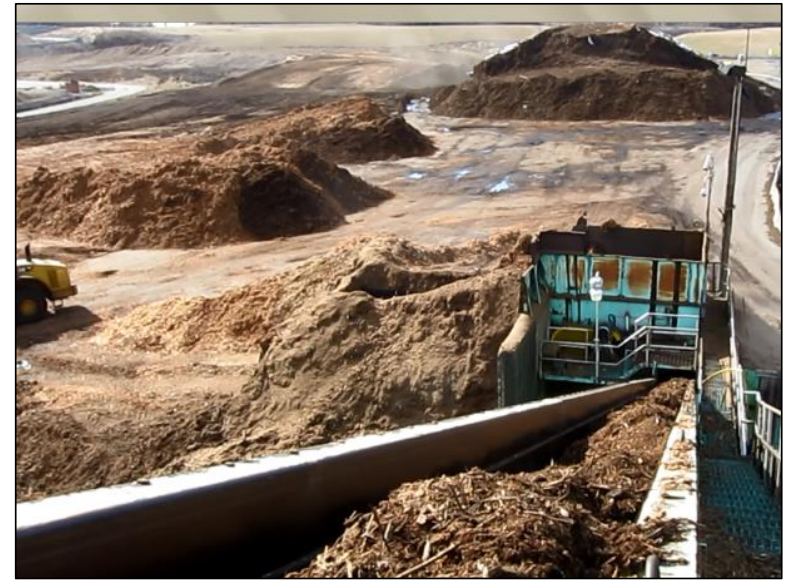

(a)

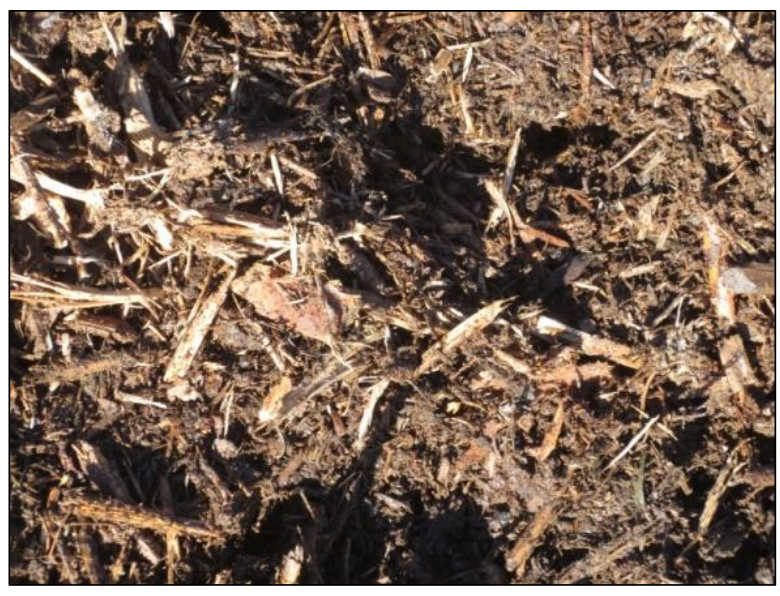

(c)

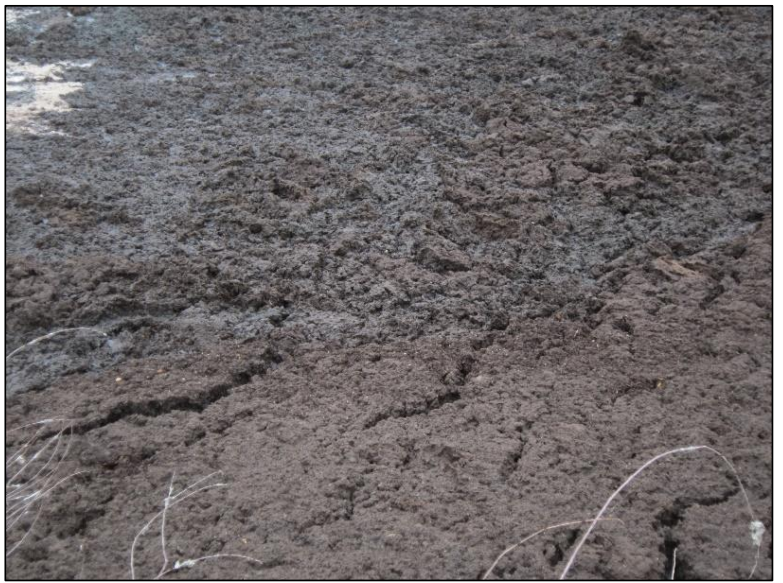

(b)

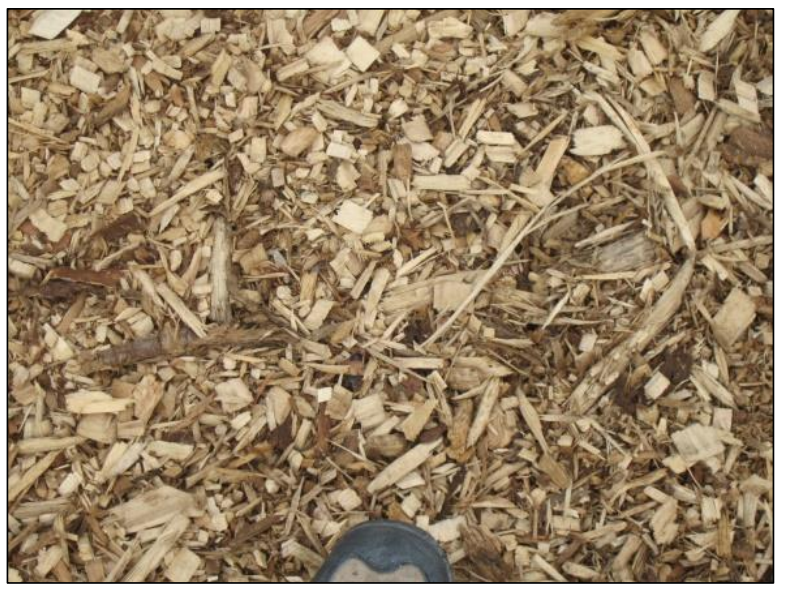

(d)

Figure 6. Different types of feedstock a) conveyor belt to boiler, b) sludge, c) older biomass pile wetted by rain and d) fairly dry biomass pile 


\subsubsection{Operational Problems}

The high variation in feedstock moisture content is an inherent problem in biomass boiler operation. Biomass feedstock typically contains 40 - $50 \mathrm{wt} \%$ moisture, but can vary from a few $\mathrm{wt} \%$ if it has been dried to over $70 \mathrm{wt} \%$ for aged feedstock, particularly that has been exposed to rain and/or stored under wet conditions. Wet biomass not only reduces the boiler steam production capacity, but also reduces the boiler's lower furnace temperature, making it more difficult to sustain the fire and to burn the already wet material. More fossil fuels (natural gas or crude oil) will have to be co-fired in order to meet the mill's steam requirement, and this can be costly and is not desirable. On the other hand, if the biomass is too dry, the combustion produces more particulate matter resulting in a high stack opacity problem. It may also increase the furnace temperature excessively leading to problems associated with wall slagging and clinker formation on the furnace grate [6].

Even for a feedstock with the same moisture content other parameters such as size, shape, and type of wood species have a significant effect on the performance of the boiler. Different types of wood species have different combustion behaviors which lead to different operating parameters [7]. All of these factors must be considered when investigating the operation of a biomass boiler.

\subsection{Biomass Moisture Content}

Moisture content contained in the structure of wood can be chemically bound water, physically bound water or free water. Free water is the apparent moisture content that must be dealt with in order to maintain a constant steam production in biomass boilers. If the biomass is exposed to rain or snow for long periods of time, the fiber saturation point of the wood structure is reached which, depending on the wood type and size, can results in moisture content as high as $80 \%$. High moisture content decreases the heating value of the biomass significantly since some heat is required to evaporate the water and increases the amount of flue gas produced which can drive the ID fan into overdrive and result in tripping the boiler.

On the other hand, if the biomass is exposed to long periods of sunshine, the moisture content can be as low as $0 \%$ or reach equilibrium with the humidity of the air resulting in 5-6\% moisture 
content. In this scenario, the furnace temperature will rise excessively and can lead to clinker or glass formation of the silicone content of the biomass or corrosion of the equipment.

In many mills, bio-sludge from the wastewater treatment section is added in to the feedstock of biomass boilers to avoid regulatory complications and high cost of landfilling. This creates high moisture content in the boiler and decreases the thermal efficiency of the boiler.

\subsection{Motivation and Objective}

In recent years extensive studies on biomass drying, combustion and ash characteristics and on the thermal conversion of biomass into bio-oil/biogas via pyrolysis and gasification have been performed by various research groups around the world [3-5, 8-32]. In the field of biomass combustion, the main studies have been on low moisture content samples (less than 20\% [8] [9]), developing kinetic model [5] [10], drying methods [11] [12], and combustion of kitchen waste material [13]. The focus, however, has not been placed on operating issues in biomass boilers, particularly those in pulp and paper mills where hog-fuel with high and constantly varying moisture content is the main component. While each pulp and paper mill has its own way of dealing with variations in moisture content and other feedstock characteristics, there is a lack of fundamental understanding of how these property changes may affect the combustion behaviour of biomass and their impact on boiler operation. The purpose of this study is to systematically investigate these effects, leading to the development of fundamental data for biomass combustion and boiler operation.

The objective of this study is achieved in two parts: laboratory experiments, where biomass combustion of single particles are investigated in a thermogravimetric combustor controlled at different temperatures, and field studies, where data analysis of 3 biomass boilers is carried out to help better understand the impact of moisture content fluctuations on the operation of biomass boilers in pulp and paper mills. 


\section{Chapter 2 \\ Literature Review}

\section{Literature Review}

As discussed in the introduction section, the effect of moisture content on the operation of biomass boilers at pulp mills has not been systematically studied, however the effect of moisture content on combustion has been sporadically studied, and some of the relevant research is presented here.

\subsection{Biomass Combustion}

Combustion is the oldest and most efficient method of utilizing the energy content of biomass. Temperatures higher than $300^{\circ} \mathrm{C}$ and ample amounts of oxygen are required for combustion to start. First the volatile content of the biomass need to reach volatilization temperature which varies from $250^{\circ} \mathrm{C}-300^{\circ} \mathrm{C}$, at this point they are emitted from the structure of the wood, and if the surrounding temperature is high enough, a flame will form. After all the volatile content of the biomass have emitted, oxygen will penetrate into the remaining fixed carbon content of the biomass and carbon oxidization will take place. If the oxygen penetrating into the biomass structure is not the stoichiometric ratio, incomplete combustion will take place which can have byproducts such as carbon monoxide [7].

Since the elemental composition of different types of biomass is relatively constant, the heating value and combustion behaviour of biomass depends on its moisture and ash content. The main reactions taking place during combustion are the oxidization of carbon and hydrogen.

$$
\begin{array}{cc}
\mathrm{C}+\mathrm{O}_{2} \rightarrow \mathrm{CO}_{2} & \Delta H=-393.5 \mathrm{~kJ} / \mathrm{mol} \\
\mathrm{H}_{2}+\frac{1}{2} \mathrm{O}_{2} \rightarrow \mathrm{H}_{2} \mathrm{O} & \Delta H=-241.8 \mathrm{~kJ} / \mathrm{mol}
\end{array}
$$

From the above reactions, the amount of theoretical oxygen required can be calculated and excess amounts of the required oxygen can be made available for complete combustion to take place. 


\subsection{Combustion of High Moisture Content Material}

The effect of water content on waste material combustion has been studied by Saito et al. [13] where balsa wood was used as sample material which is representative of the physical properties of the waste material. Their results suggested that drying and devolatilization stages of combustion overlap for high moisture content and the volatile burning rate drastically decreased with increasing moisture content.

Shanmukharadhya and Sudhakar [8] studied the effect of moisture content on combustion in bagasse fired furnaces. Their results showed that moisture content caused a significant delay in the start of combustion and ignition. They also reported that the combination of particle size and moisture content played an important role in the stability of the furnace operation.

Suksankraisorn et al. [9] reported that waste material with moisture content higher than $20 \%$ did not ignite at a furnace temperature of $600^{\circ} \mathrm{C}$. For lower moisture contents optimum carbon combustion efficiency was reached with $10 \%$ moisture content. Diego et al. [14] developed a model for the devolatilization of wet pine wood particles in fluidized beds. They observed that the devolatilization times increased with increasing moisture content and their model predicted the same trend. Their model however, only predicted combustion behaviour for samples with moisture content up to 50\% and did not include the char burning stage of combustion.

Incineration of bio-sludge has been investigated by different researchers since it is a safer alternative to landfilling or use as fertilizer which have potential hazards and risks. Nevertheless, the formation of hazardous by-products is still a concern. In addition to environmental issues, the high moisture content of sludge, both free and bound water, causes problems for sludge dewaterability as well as combustion. The effect of moisture content on bio-sludge combustion has been studied by Shin et al. [15] both in a batch type combustor and cyclone circulating fluidized bed. They concluded that the optimum combustion of carbon can be reached with $35 \%$ water content in the sludge. The combustion characteristics of wet sewage sludge (80\% moisture content) in a fluidized bed have been studied by Ogada and Werther [16]. Their results showed that there is significant overlap between drying, devolatilization, and char combustion stages to the extent that the three stages could be thought to occur simultaneously. 


\subsection{Fixed Bed Combustion}

Biomass combustion in stoker-grate type boilers is one type of fixed bed combustion, which has been studied extensively. Shin and Choi [18] proposed a mechanism for the combustion of waste particles in a fixed bed. They identified two distinct reaction modes based on the availability of oxygen: the oxygen limited mode and the reaction limited mode. The flame disappearance is caused by the increase in flow rate of air which results in excessive cooling by convection. From the heat and mass transfer mechanisms, radiative heat transfer in the bed was found to be important in initiating the flame front and in transferring heat to the cold bed.

Yang et al. [19] studied the effect of fuel moisture content for modelling waste combustion in grate furnaces. Their model predicted that wetter fuels take a longer time to ignite and the average burning rate in the bed decreases with an increase in moisture content of the fuel.

Another important parameter in fixed bed combustion is the fuel particle size. Yang et al [20] studied the fuel size effect on combustion of pinewood cubes ranging in size from 5 to $35 \mathrm{~mm}$. Their research showed that the smaller particles ignited more quickly and had higher burning rates, whereas larger particles created more distinctive combustion stages with less overlap, and produced a higher flame temperature

Bruch et al. [21] developed a computer model for the conversion of wood under packed-bed conditions with particle sizes ranging from 5 to $25 \mathrm{~mm}$. Their single-particle model considered each particle undergoing heating, drying, pyrolysis, gasification, and combustion. They also conducted experiments to validate the single particle model for beech wood conversion during pyrolysis and char burning and the agreement between the model and the experiments were satisfactory with the exception of wet wood with $67 \%$ moisture content where the pyrolysis rates were not accurately estimated. 


\subsection{Biomass Boilers in Pulp and Paper Mills}

The high and constantly varying moisture content of the feedstock has been an ongoing challenge from the perspective of pulp mills. McDermott et al. [21] investigated the effect of wet feedstock from the boiler operators' experience and came to the conclusion that the maximum moisture content of the feedstock is 55\% for stable combustion using 50\% excess air preheated to $200^{\circ} \mathrm{C}$. Their findings however, were not confirmed by systematic experimental data and were only based on the experience at different mills.

Linderoth [22] studied the advantages of drying the feedstock and demonstrated theoretical calculations for changes in boiler efficiency, grate heat release, adiabatic combustion temperature, excess air ratio and steam generation with fuel moisture levels. The theoretical boiler efficiency decreases from $80 \%$ to $70 \%$ for increase in moisture content from $20 \%$ to $40 \%$ and for moisture contents higher than $60 \%$, the efficiency drops below 55\%. For this study, even though theoretical values are discussed, the findings are not supported by experimental observations and a fundamental understanding of the effect of changes in moisture content on the combustion characteristics in biomass boilers is not presented.

In summary, the combustion characteristics of different biomass material has been investigated by other researchers, however the emphasis has not been on the feedstock of biomass boilers at pulp mills with constantly varying properties such as moisture content. Moreover, the focus of most studies has been on modelling of combustion, either as a single particle or in boilers with continuous feed, but the findings have not been supported by experimental observations. Therefore, there is a need for fundamental understanding and systematic study of biomass combustion characteristics related to biomass boilers in pulp and paper mills which is the main objective of this work. 


\section{Part I: Laboratory Experiments}

In order to investigate the effect of moisture content on biomass combustion, laboratory experiments with two setups were carried out. First, the water absorption of different types of wood species was studied by soaking biomass samples in water and measuring changes in weight. Second, a thermogravimetric combustor was used to run biomass combustion experiments with different sample properties and furnace temperatures. 


\section{Chapter 3 \\ Water Absorption Experiments \\ 3 Water Absorption Experiments}

Changes in moisture content of woody biomass were studied to find the effect of biomass type, cut orientation and duration of water exposure.

\subsection{Methodology}

Depending on the cut surface of the wood particle, the directions can be transverse, tangential or radial as shown in Figure7. In order to better understand the effect of moisture content and the behaviour of water inside the wood particle, a series of experiments was carried out to first determine the water absorption characteristics of different surfaces of the wood particle.

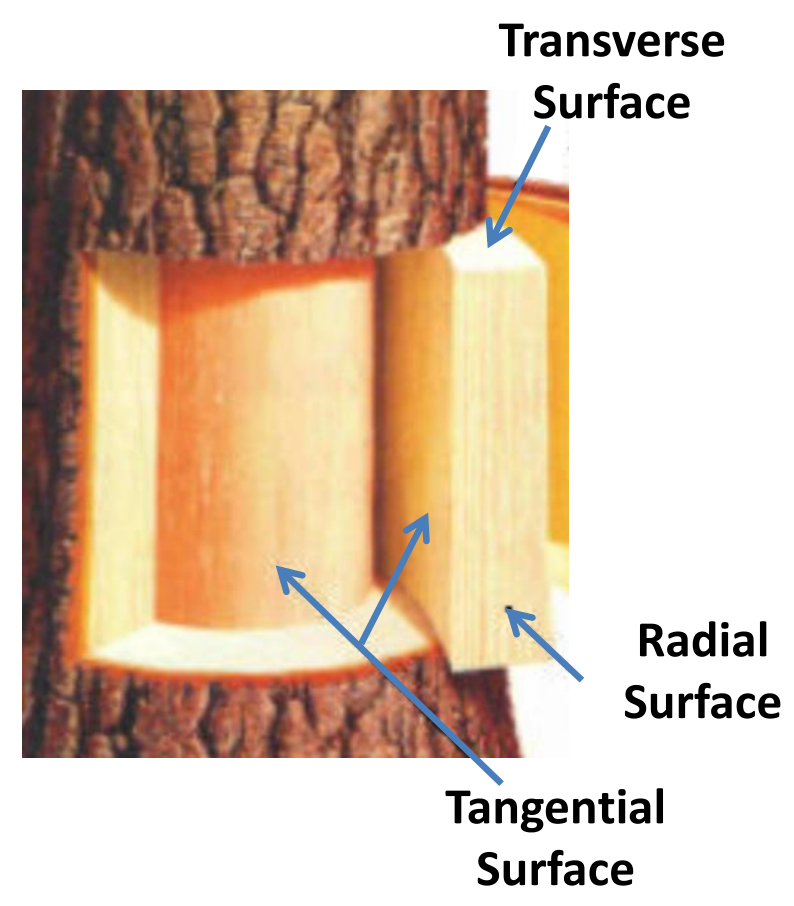

Figure 7. Wood structure cut surfaces [21] 


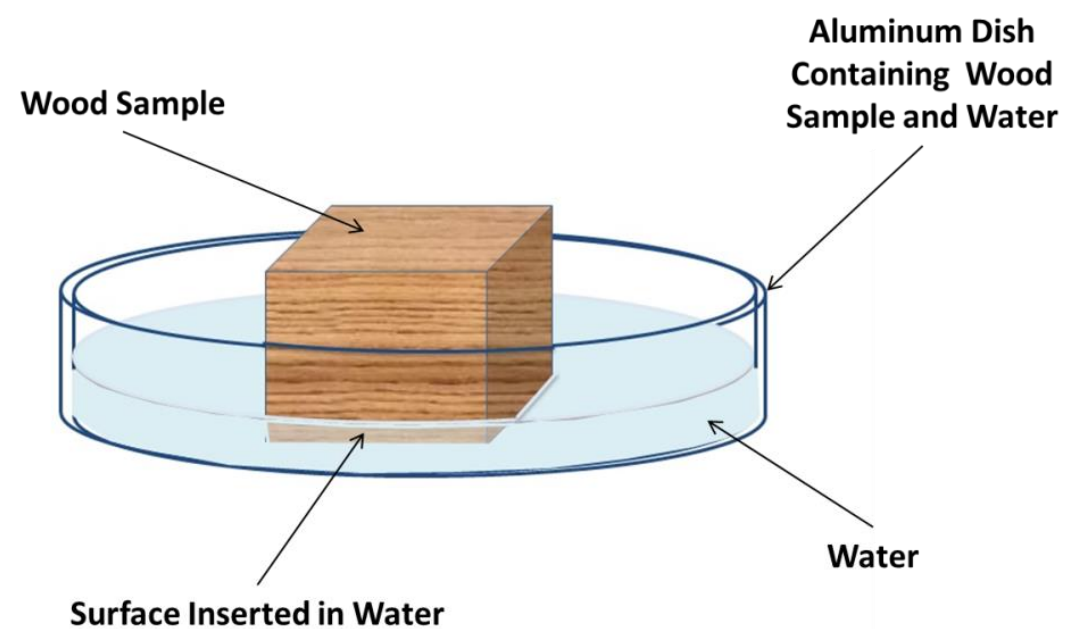

Figure 8. Setup for water absorption experiments

\subsubsection{Sample Preparation}

Untreated maple and cedar wood panels were purchased from the Home Depot and cut into cuboids with $1.2 \mathrm{~cm} \times 1.2 \mathrm{~cm} \times 1.2 \mathrm{~cm}$ dimensions. The transverse, tangential and radial surfaces were identified and all surfaces were covered with aluminum type tape except for the surface which would be exposed to water. In order to have one sample from each surface exposed, 3 samples from each wood species were prepared.

\subsubsection{Test Procedure}

Three samples each exposing different wood surfaces were prepared (Figure 9a). The initial dry weight of the samples was measured. The samples were inserted in water from the exposed surface at the same time as shown in Figure $9 \mathrm{~b}$ and the change in weight after specific time intervals was measured. 


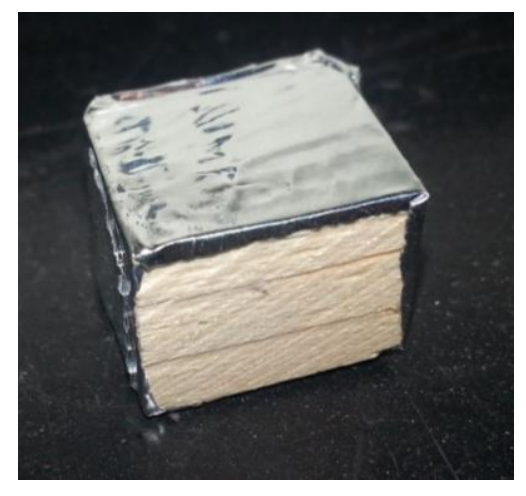

(a)

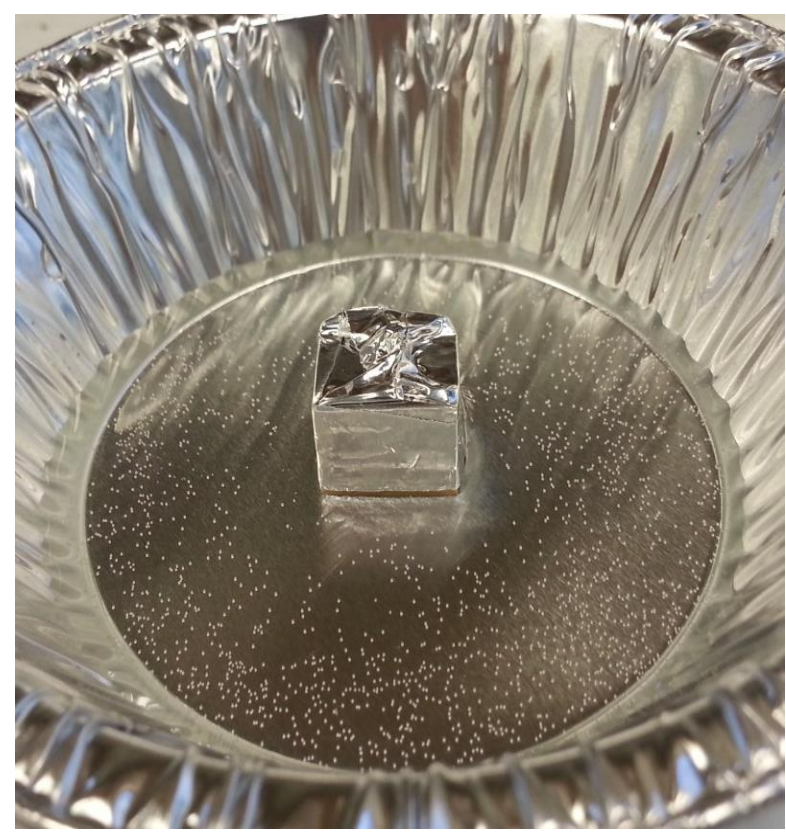

(b)

Figure 9. Water absorption experiment a) cedar sample with all surfaces covered except for radial surface b) radial surface of cedar sample inserted in water 


\subsection{Results and Discussions}

\subsubsection{Water Absorption and Wood Orientation}

Figure 10 shows the results of water absorption from different surfaces for cedar. It was observed that for softwoods, the highest rate of water absorption was on the transverse surface, this can be explained by the empty structure of the vessels which are exposed on the transverse surface. For hardwoods on the other hand, the water absorption of the different surfaces were very similar and the tangential surface had a slightly higher absorption rate, as shown in Figure 11. This can be explained by the dense structure and compaction of hardwood species where the different cut surfaces do not have varying amounts of empty space for water to penetrate into the structure.

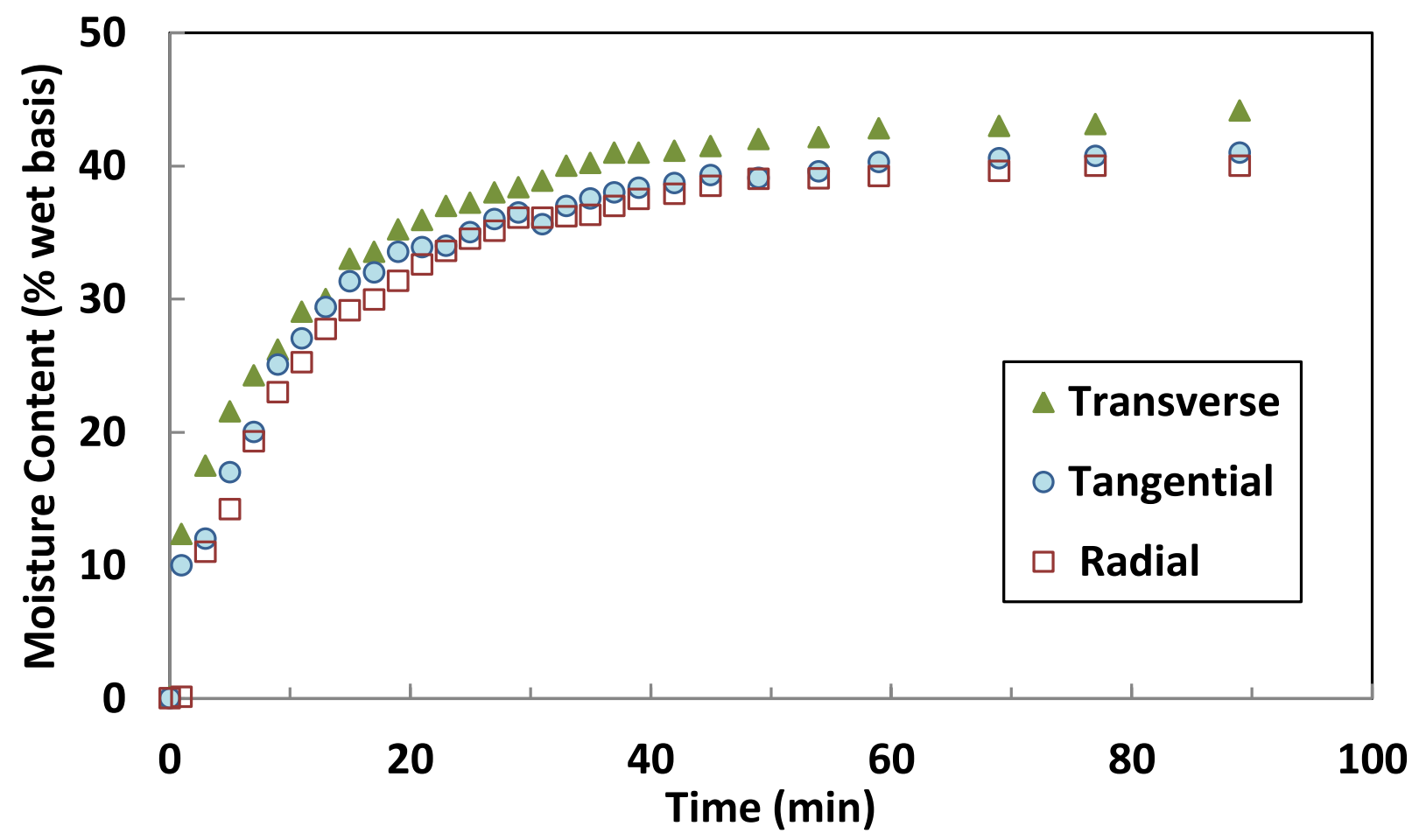

Figure 10. Water absorption for softwood (cedar) 


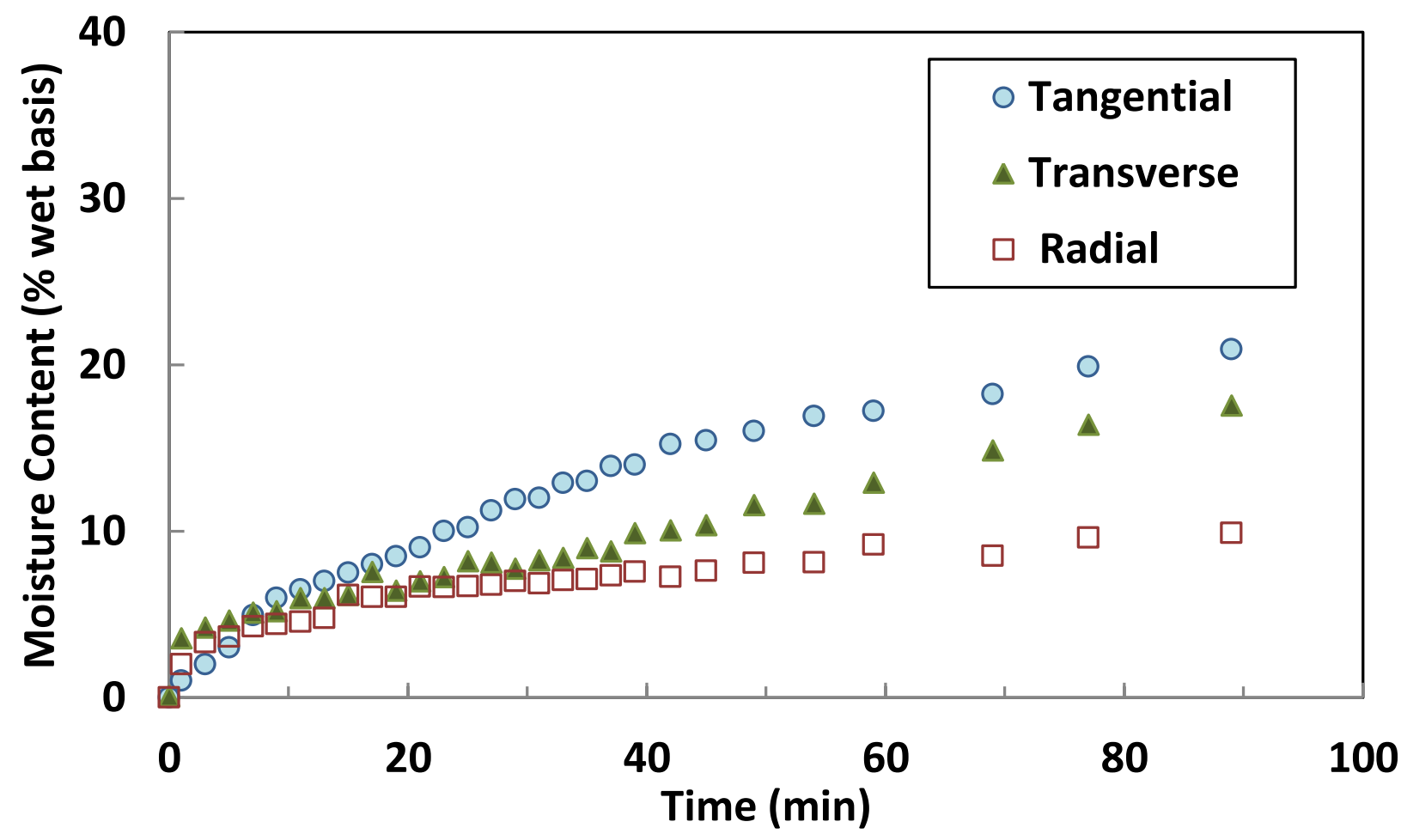

Figure 11. Water absorption for hardwood (maple)

Comparing Figure 10 with Figure 11, it is clear that the rate of water absorption is faster for softwoods and after 40 minutes of exposure to water, the moisture content of softwoods reaches almost $40 \%$ whereas the moisture content of hardwoods reaches only $15 \%$. This difference in rate of water absorption can also be explained by the difference in wood structure and density between hardwoods and softwoods. For samples with equal volume, the softwood structure has more empty spaces for water penetration and absorption, whereas for hardwoods, the compact structure allows less water penetration and therefore, a slower increase in moisture content. 


\subsubsection{Maximum Moisture Content}

For studying the effect of moisture content on combustion, samples with different moisture contents were prepared from different wood species. It was observed that, depending on the wood type, the maximum moisture content reached after 4 weeks of water exposure, was different. Table 1 shows the maximum moisture content achieved for different wood types when left in water for 4 weeks. It shows that for increasing wood density, the maximum moisture content decreases. Also for saw dust with particle sizes ranging from $0.42 \mathrm{~mm}$ to $1.12 \mathrm{~mm}$, the maximum moisture content reached was $80 \%$ which was higher than that of wood chips suggesting that due to the smaller size of sawdust, the collective surface area of the sample was higher, and therefore the maximum moisture content reached was also higher.

Table 1. Maximum moisture content possible for different wood species up to 4 weeks of water exposure

\begin{tabular}{|r|c|c|c|c}
\hline & $\begin{array}{c}\text { Wood } \\
\text { Species }\end{array}$ & Sample Size & Density $\left(\mathrm{g} / \mathrm{cm}^{3}\right)$ & $\begin{array}{c}\text { Maximum Moisture } \\
\text { Content }(\%)\end{array}$ \\
\hline Mix & Saw Dust & $0.42 \mathrm{~mm}-1.12 \mathrm{~mm}$ & 0.15 & 80 \\
\hline Softwood & Cedar & & 0.33 & 62 \\
\hline & Pine Bark & & 0.37 & 59 \\
\hline & Pine & $1.5 \mathrm{~cm} \times 1.2 \mathrm{~cm} \times 1.2 \mathrm{~cm}$ & 0.39 & 60 \\
\hline Hardwood & Poplar & & 0.56 & 46 \\
\hline & Oak & & 0.62 & 43 \\
\hline & Maple & & 0.76 & 46 \\
\hline
\end{tabular}




\section{Chapter 4 \\ Combustion Experiments}

\section{Combustion Experiments}

In order to systematically study the effect of moisture content on combustion, the thermogravimetric combustor at our laboratory was used which not only continuously records the weight change of the sample, but also allows for monitoring of the physical appearance of the combustion process.

\subsection{Experimental Setup}

\subsubsection{Thermogravimetric Combustor}

In order to fairly compare the combustion behaviors of various types of biomass samples, tests need to be carried out under the same conditions. For this purpose, a thermogravimetric (TG) combustor was constructed that can handle various types of samples and provide more quantitative insight into the combustion process.

Figure 12a schematically shows the TG-combustor used in this study. It consists of an electrical furnace, a high precision balance, a high-definition digital camcorder, and a gas control system. The furnace is a $34 \mathrm{~cm}$ tall octagonal cylinder with a $5 \mathrm{~cm}$ side length (Figure 12b). It has a 10 $\mathrm{cm} \times 10 \mathrm{~cm}$ quartz glass observation window mounted on its front wall. The furnace is placed on a sliding stand that can be moved up and down along a rigid steel frame. The sliding stand is connected to a long lever arm with a pedal at the end. By stepping on the pedal, the entire furnace assembly can be lifted up quickly and locked in a fixed position closer to the balance. It can also be lowered down to its original position by releasing the position lock. The balance, capable of measuring up to $200 \mathrm{~g}$ with a readability of $1 \mathrm{mg}$, is placed on a well-insulated board directly above the furnace. It is completely separated from the furnace so that the sample weight measurement will not be interfered by the furnace movement and vibration. The camcorder is mounted on a tripod $75 \mathrm{~cm}$ away from the furnace, with its lens zoomed on the sample in the furnace through the quartz glass window. The gas control system regulates compressed air and passes it through an air distributor at the bottom of the furnace. 


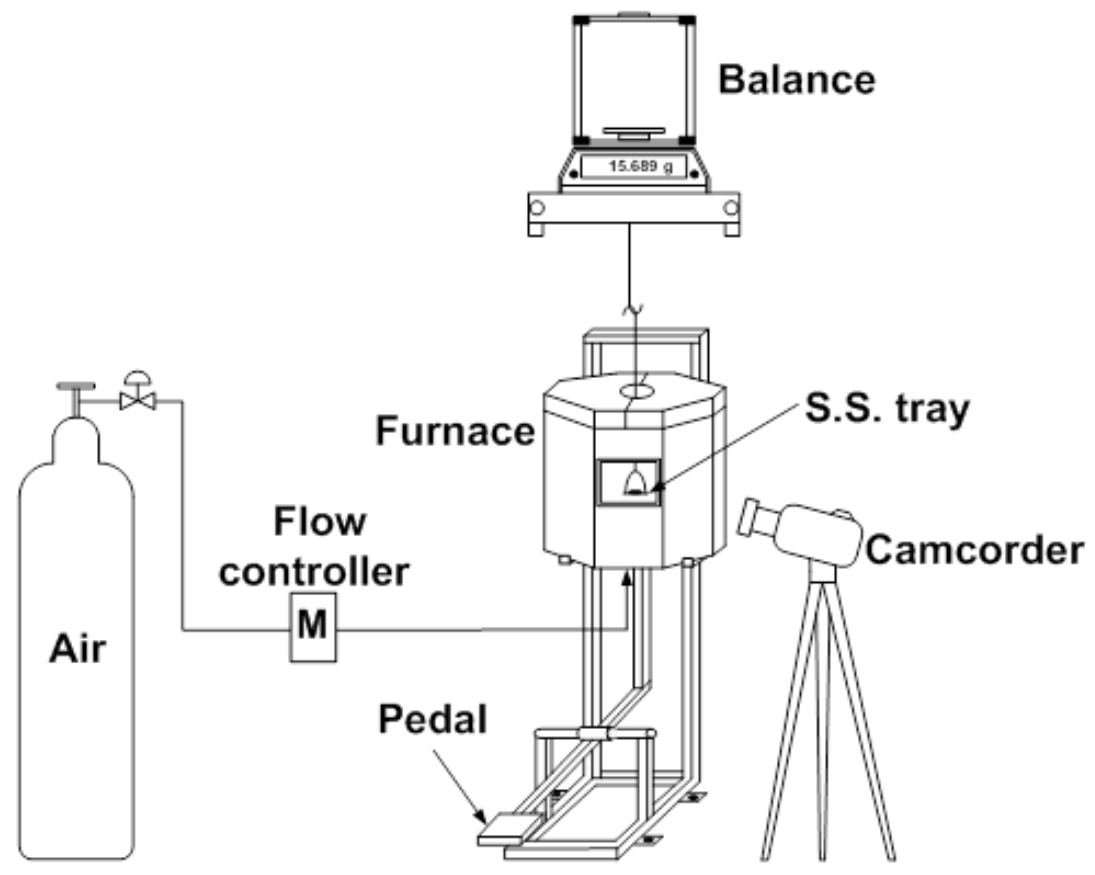

(a)

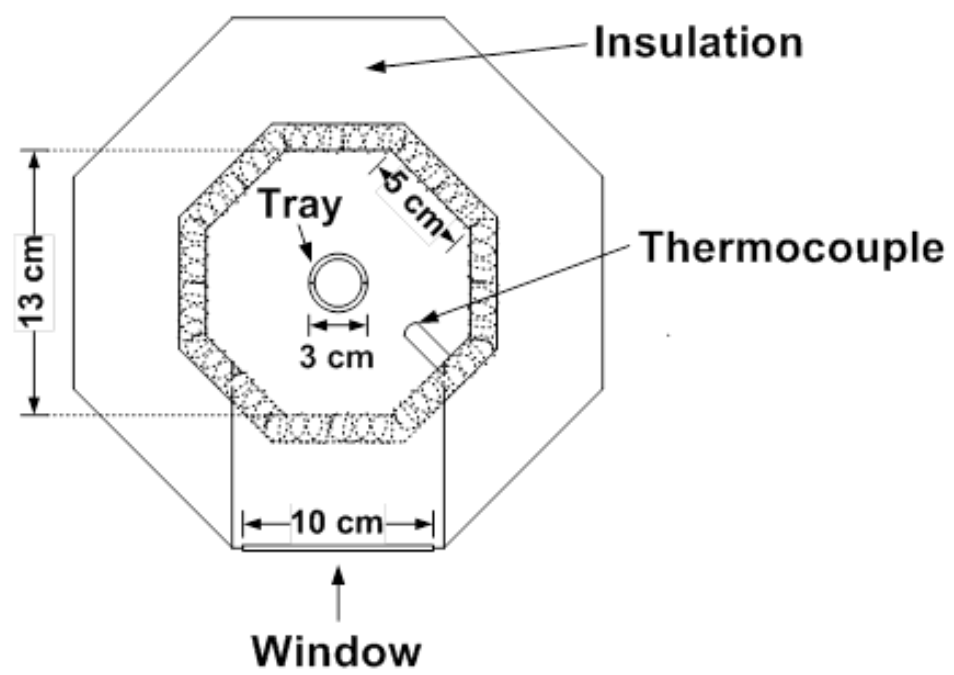

(b)

Figure 12. a) Thermogravimetric (TG) combustor and b) Cross section of the electrical furnace 


\subsubsection{Sample Preparation}

In this study, samples were prepared from 5 different wood species purchased from the Home Depot: cedar, pine, poplar, oak, and maple. They were cut into cuboids with the desired dimensions for each set of experiments. These wood blocks were soaked in water at ambient temperature for 24 hours, and then dried at $105^{\circ} \mathrm{C}$ in an oven for different lengths of time to produce samples with different moisture contents. The moisture content of each resulting sample was calculated based on the difference in the sample weight before soaking it in water and after drying it in the oven, and according to the following formula:

$$
M C \%=\frac{\text { original weight }- \text { oven dried weight }}{\text { original weight }} \times 100
$$

\subsubsection{Test Procedure}

The furnace temperature was controlled and monitored using a K-type thermocouple placed near the test sample (Figure 12b). In order to allow combustion air to be well distributed from all sides of the sample, the sample was placed on a stainless steel type 316 mesh tray ( $3 \mathrm{~cm}$ O.D.) and hung on a hook underneath the balance. After the sample weight was appropriately tared and the tray became stable, the camcorder was turned on. The furnace was subsequently pushed up to quickly lower the sample tray into the middle of the furnace. The sample appearance was recorded by the camcorder through the glass window, while the sample weight was continuously recorded by the balance. During the test, the air flow was controlled at $1 \mathrm{~L} / \mathrm{min}$. The time required for each combustion stage was determined based on video images recorded by the camcorder and the weight loss registered by the balance. 


\subsection{Results and Discussions}

\subsubsection{Combustion Behaviour}

Figure 13 shows, as an example, still images of the combustion of a $1.34 \mathrm{~g}$ cube of oak $(1.5 \mathrm{~cm} \times 1.2 \mathrm{~cm} \times 1.2 \mathrm{~cm})$ with $20 \%$ moisture content at $800^{\circ} \mathrm{C}$. The time (minutes: seconds) at which the image was taken is displayed at the bottom right corner of each frame. The first frame (00:00) is the appearance of the sample at the instance it was inserted into the furnace. For the first few seconds, only slight blackening or charring was observed around the edges of the sample. This suggests that the sample surface temperature was sufficiently high for the water to dry and for the volatiles to release, but was not sufficient for the volatiles to ignite. A yellow flame appeared after 4 seconds (00:04), indicating the beginning of the volatile burning stage in which the volatile content of the sample was emitted and the temperature of the surrounding was high enough for the volatiles to ignite and form a flame. As the combustion heat further transferred into the sample interior, volatile burning became more intense, producing a larger flame. The flame fully enveloped the sample at (00:15), but its intensity appeared to slowly diminish with time. The flame eventually disappeared at (01:05) indicating the end of the volatile burning stage and the beginning of the char burning stage. As the char continued to burn, it glowed brighter (01:05), further illuminating the surrounding of the sample (comparing (01:30) and (02:00)). At the end, char burning stopped and a small amount of ash was left over (05:11). These video images confirmed that drying and volatile burning are fast (about 1 minute) and overlap with each other due to the non-uniform temperature distribution within the sample. Char burning is much slower, and it requires more than 5 minutes to complete. 

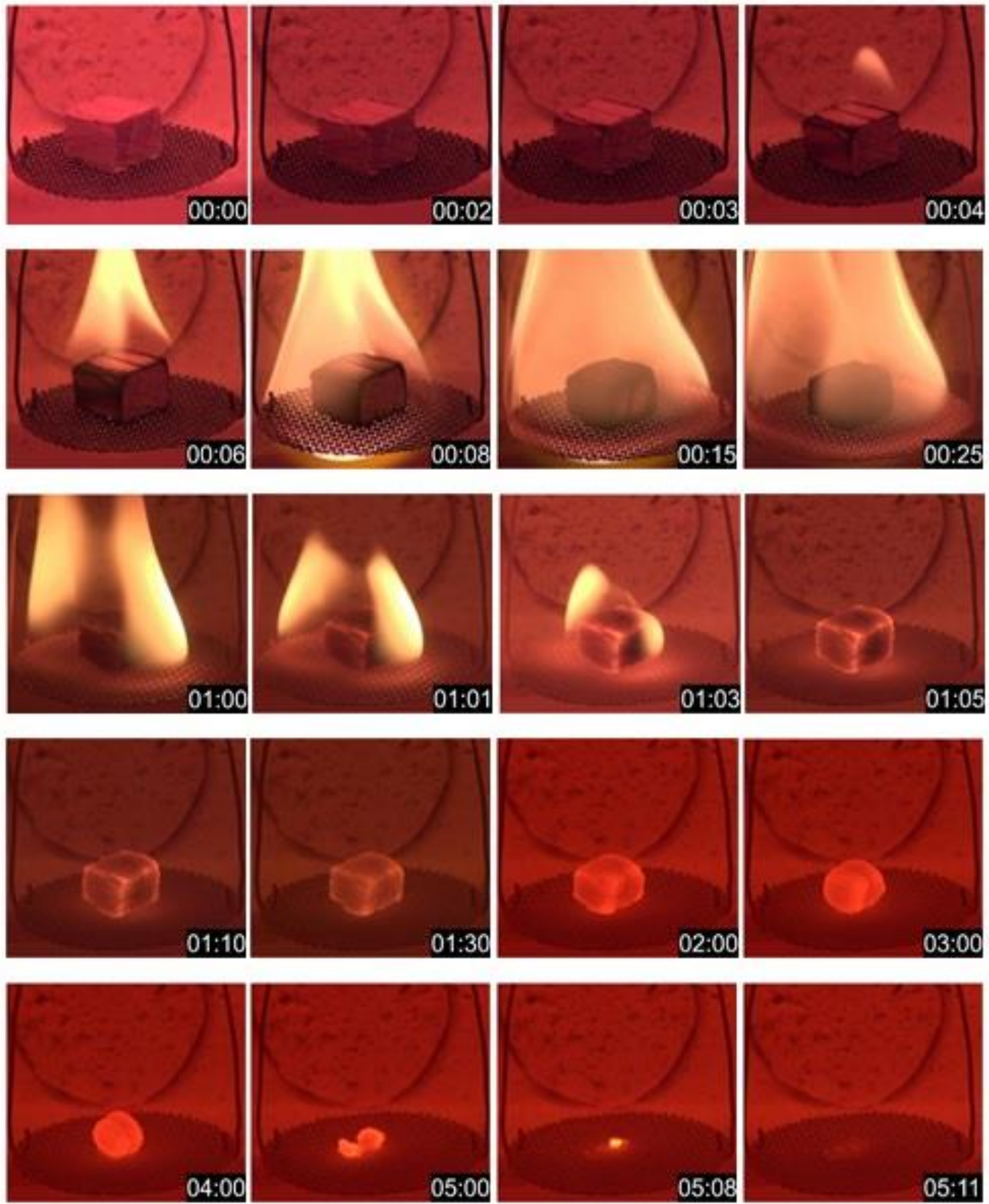

Figure 13. Combustion of a $1.34 \mathrm{~g}$ oak sample with $20 \%$ moisture content at $800^{\circ} \mathrm{C}$ (time displayed in mm:ss) 


\subsubsection{Combustion Stages}

From the combustion video of a biomass sample, there are four distinct times that may be used to characterize the combustion behaviour of the sample. In the case shown in Figure 13, for example, Time 'A' was the moment the sample was inserted into the furnace (00:00), Time 'B' was when the sample caught fire as a result of volatile burning (00:04), Time ' $\mathrm{C}$ ' was when the flame disappeared indicating the end of the volatile burning stage (01:05), and Time ' $D$ ' was when the char no longer glowed indicating the end of the char burning stage (05:11). Based on these times, the combustion stages were defined as:

- Time-to-Ignition (from A to B)

- Volatile Burning (from B to C)

- Char Burning (from C to D)

Combustion tests were performed on over 300 samples of different wood species and moisture contents. Figure 14 shows the duration of the combustion stages for all of the samples which were tested in the thermogravimetric combustor at $800^{\circ} \mathrm{C}$. In this figure, the time-to-ignition or drying duration is shown with diamond shaped markers, volatile burning duration is shown with triangles, and char burning duration is shown with squares. It is evident that the drying duration is much shorter than the volatile burning or the char burning for all samples. As the moisture content increases, the drying duration also increases but compared to the overall combustion duration, this increase is not significant up to $30 \%$. For moisture contents higher than $30 \%$, on the other hand, the increase in drying time or time-to-ignition increases exponentially. The volatile burning duration also shows an increasing trend with moisture content. The results shown here in Figure 14 are from different samples with different compositions and sizes. Therefore the differences in the volatile content, fixed carbon content and ash content have an effect on the combustion stages. This is why the values for the char burning duration shown in Figure 14 do not show a specific trend and vary from 2 minutes to more than 6 minutes. The effect of moisture content on different types of wood species is discussed in detail in the following sections. 


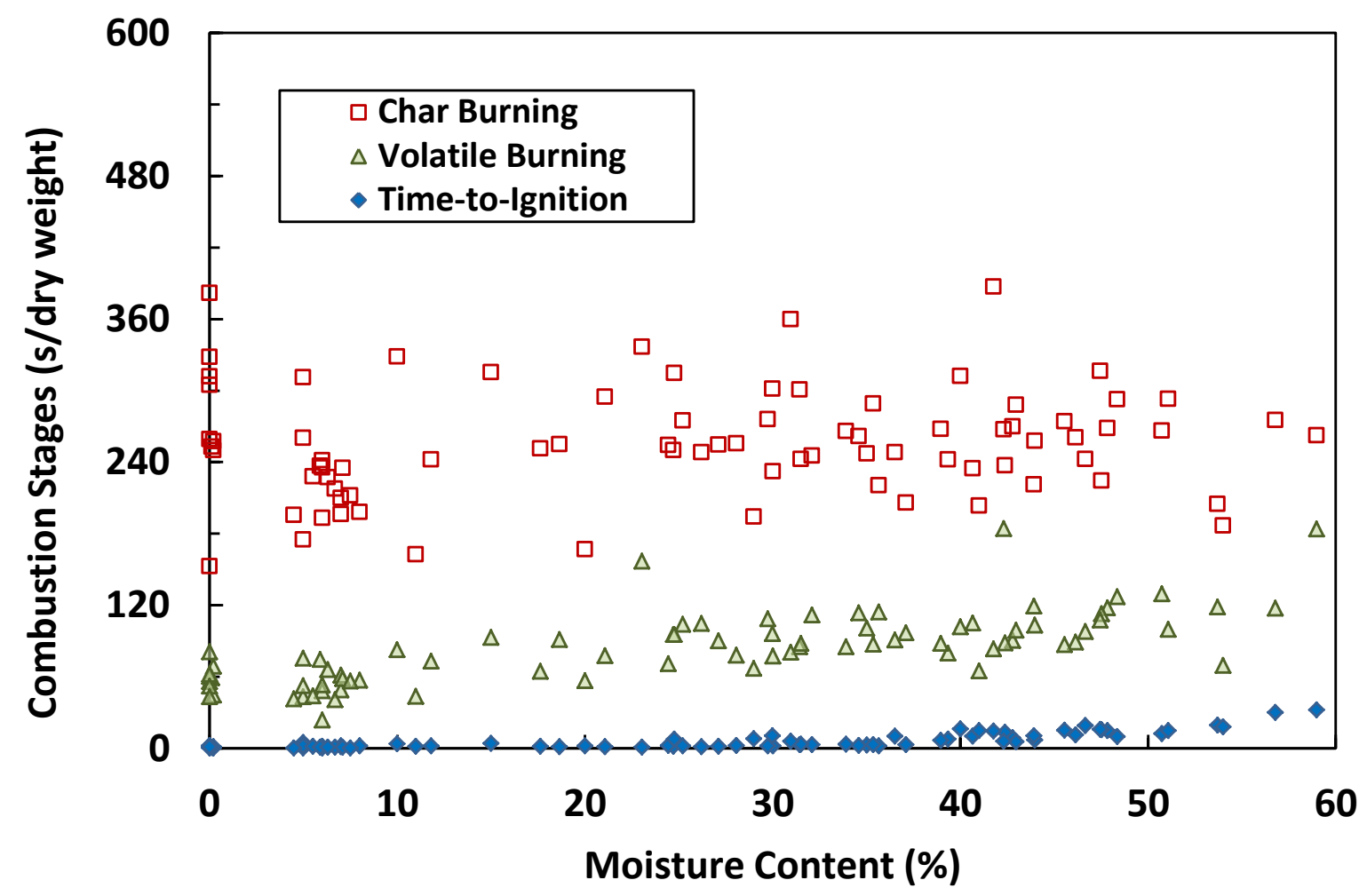

Figure 14. Combustion stages of biomass samples $(1.5 \mathrm{~cm} \times 1.2 \mathrm{~cm} \times 1.2 \mathrm{~cm})$ burned at $800^{\circ} \mathrm{C}$

Figure 15 shows an example of a weight change profile during the combustion of oak at $800^{\circ} \mathrm{C}$. Drying (vaporization of water) and volatile burning are thermal processes that occur rapidly at low temperatures $\left(100^{\circ} \mathrm{C}\right.$ for water evaporation and $250-300^{\circ} \mathrm{C}$ for biomass pyrolysis). Due to the uneven temperature distribution across the sample, drying and volatile burning are often overlapped, making it difficult to distinguish them. As a result, the moisture content and the volatile content of the sample are lumped together as the total weight loss from $\mathrm{A}$ to $\mathrm{C}$ on the graph.

On the other hand, since char burning is a relatively slow solid-gas reaction that occurs at a much higher temperature $\left(>600^{\circ} \mathrm{C}\right)$ compared to volatile burning, there is no overlap between volatile burning and char burning. The weight loss from $\mathrm{C}$ to $\mathrm{D}$ is the same as the char content and the remaining weight ( $\mathrm{D}$ onward) is the same as the ash content. 


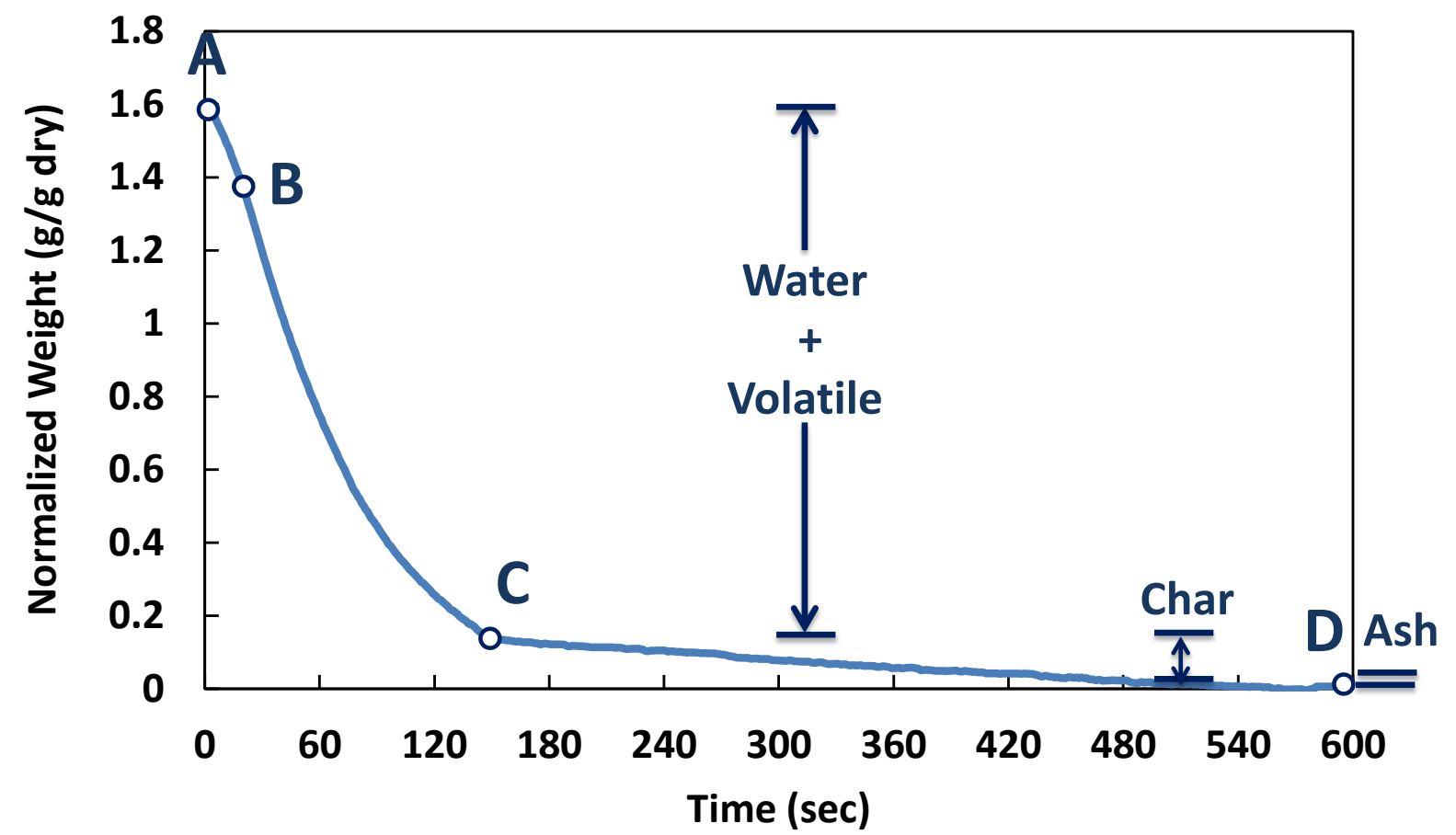

Figure 15. Weight change profile for combustion of oak at $800^{\circ} \mathrm{C}(1.34 \mathrm{~g}$ dry sample, $40 \%$ moisture content)

From the weight change profile of each sample, the volatile content, fixed carbon content and ash content can be determined in weight percentages. If the moisture content of the sample is known, the weight change during volatile burning, during which a flame is present, is the volatile content, and the weight change during char burning is the fixed carbon content of the biomass sample. It is also evident from the weight change profile, that even though the volatile content of the biomass sample is almost $80 \%$ of the total weight, the volatile burning duration is shorter than the char burning duration. Therefore, the rate determining step for the overall combustion is the char burning stage. 


\subsubsection{Effect of Surface Area}

One of the characteristics of the feedstock that needs to be studied thoroughly is the shape and size of the biomass. Dry sawdust, for instance, can burn up instantly as it is blown into the boiler, whereas large clumps of wood may take a much longer time to burn, and the combustion is much less intense. Understanding these effects would provide design guideline on the extent of pulverization and the extent of drying; it would also provide the required correlation to predict and then optimize the boiler operation, minimizing the emission of pollutant, and improving the overall efficiencies while maintaining the optimum operating air-to-fuel ratio. As a first step towards understanding the effect of shape for a fixed sample weight, experiments were carried out in the thermogravimetric combustor on samples with varying surface area.

Table 2 shows the sample sizes used for studying the effect of surface area on combustion. It can be seen from the shape of the samples, increasing the surface area for a fixed volume and weight, creates samples that are longer and thinner where samples with lower surface areas tend to be bulkier and have a more cubic-like form.

Table 2. Poplar sample sizes with different surface areas (1.21 g dry sample)

\begin{tabular}{|l|l|l|l|l|}
\hline Shape & $\begin{array}{r}\text { Length } \\
(\mathrm{cm})\end{array}$ & $\begin{array}{r}\text { Width } \\
(\mathrm{cm})\end{array}$ & $\begin{array}{r}\text { Height } \\
(\mathrm{cm})\end{array}$ & $\begin{array}{r}\text { Surface Area } \\
\left(\mathrm{cm}^{2}\right)\end{array}$ \\
\hline & 1.4 & 1.3 & 1.2 & 10.6 \\
\hline & 2.0 & 1.2 & 1.0 & 11.2 \\
\hline & 2.6 & 1.1 & 0.9 & 12.1 \\
\hline
\end{tabular}


The combustion results are shown in Figure 16 where the weight change profile of all the samples is shown. It can be seen that for samples with higher surface area, the slope of the volatile burning section of the curve is steeper, and moving to the samples with lower surface area, the volatile burning rate decreases. The same trend can be seen for char burning with a less obvious difference for changes in surface area. This is an indication that thinner samples seem to burn faster since a higher surface area means more surface is available for heat penetration in the volatile burning stage, and higher oxygen penetration during char burning stage. Therefore the sample burns more readily.

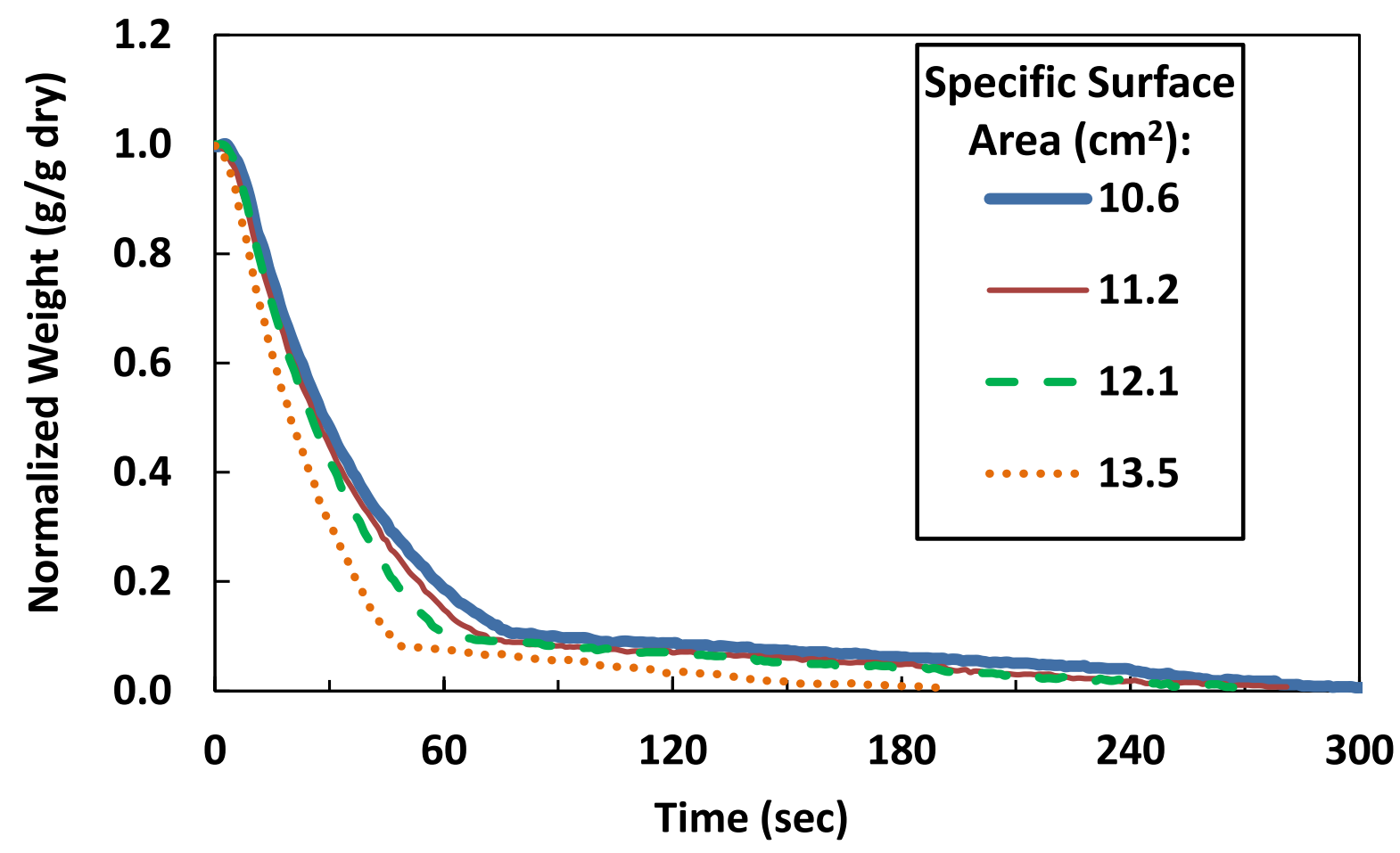

Figure 16. Combustion of poplar at $800^{\circ} \mathrm{C}$

Figure 17 shows the duration of combustion stages for poplar samples with different surface area and shape. The time-to-ignition, volatile burning and char burning all show a slight decrease with increase in surface area which suggest that for higher surface area, the overall combustion duration is shorter. Similar results obtained for oak and pine can be found in Appendix 1. 


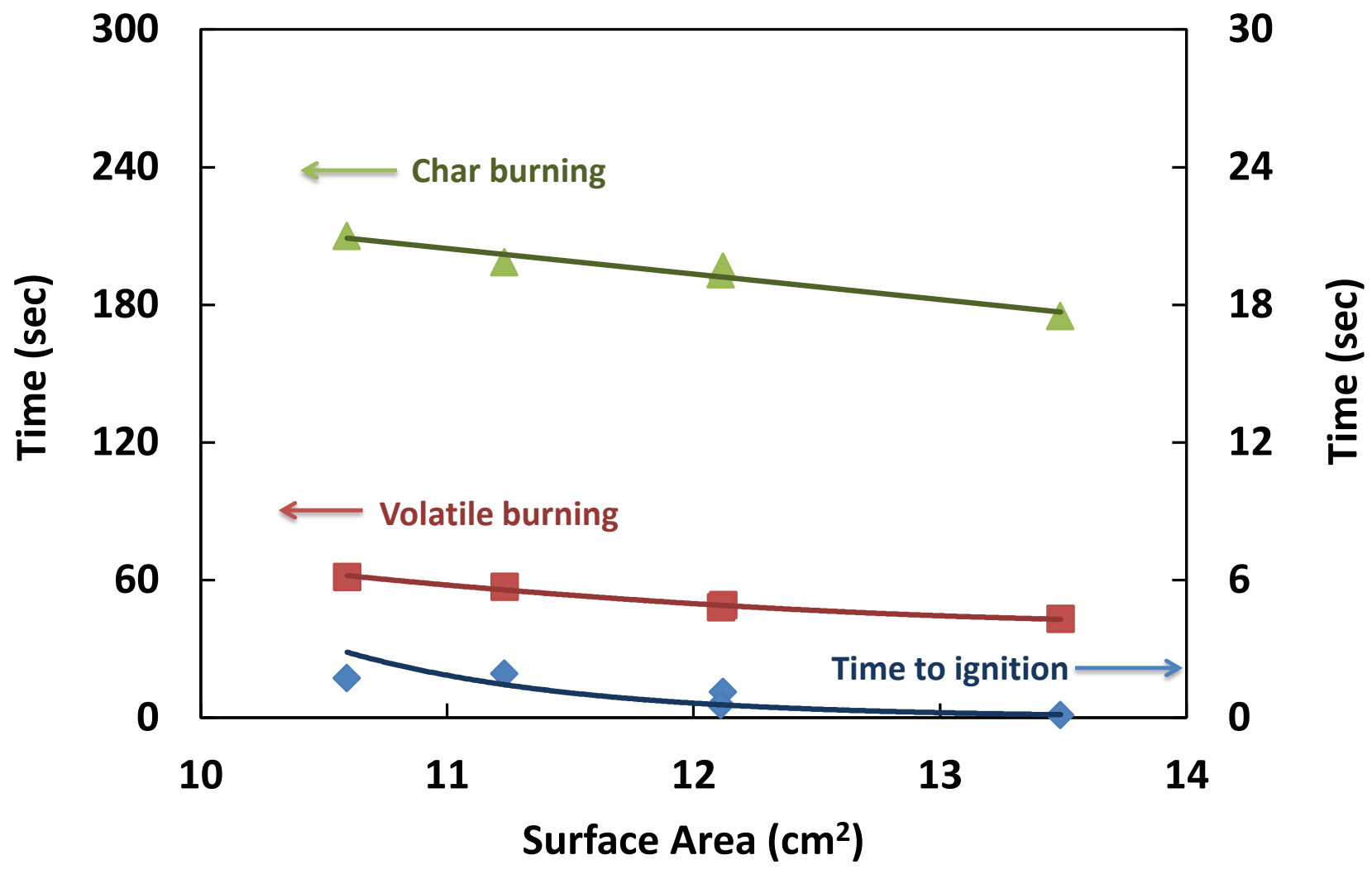

Figure 17. Combustion stages for poplar during combustion at $800^{\circ} \mathrm{C}$

\subsubsection{Effect of Moisture Content}

\subsubsection{Moisture Content Comparison}

Figure 18 shows the weight change profiles of pine with different moisture contents during combustion at $800^{\circ} \mathrm{C}$. The y-axis shows the normalized weight of the sample with its dry weight. Therefore the starting point for $0 \%$ moisture content is $1 \mathrm{~g} / \mathrm{g}$ dry. For $44 \%$ moisture content the total initial weight of the sample is $1.4 \mathrm{~g}(0.8 \mathrm{~g}$ dry $+0.6 \mathrm{~g}$ water $)$ and normalized with the initial dry weight, the starting point of the weight change profile is $1.7 \mathrm{~g} / \mathrm{g}$ dry.

From the weight change profile, the combustion stages for different moisture contents can be compared. Since the time-to-ignition stage is much shorter compared to volatile and char burning, it is difficult to see the differences from the weight change profile and comparisons can be made from the duration of this stage which is discussed below. For volatile burning on the 
other hand, the difference in slope is clear with change in moisture content. For lower moisture contents the slope of the volatile burning stage seems to be steeper indicating a higher rate. Towards the end of the volatile burning stage, the similarities in the slope of the weight change profile suggests that once all the water content has evaporated from the sample, the volatile burning rate becomes the same for samples burnt at the same furnace temperature.

For the char burning stage, the slope for all moisture contents is almost the same. For lower moisture contents, the change in slope indicating the onset of the char burning stage occurs earlier, however, once the char burning stage starts, all the samples seem to have the same slope and therefore the same char burning rate.

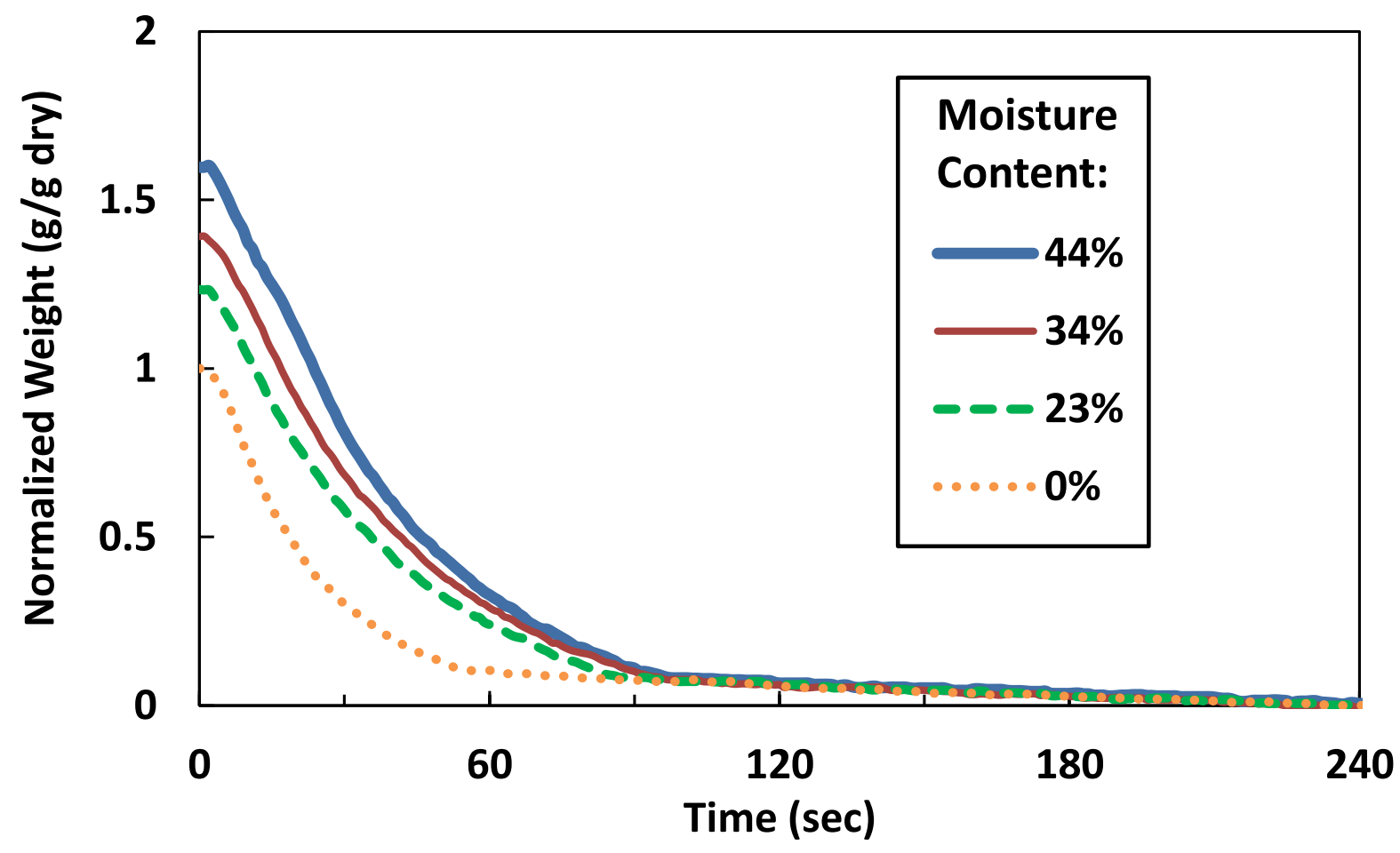

Figure 18. Effect of moisture content on the weight change profiles of pine during combustion at $800^{\circ} \mathrm{C}$. (All samples have an initial dry weight of $0.8 \mathrm{~g}$ ).

Figure 19 shows the change in duration for all combustion stages with moisture content. The char burning and volatile burning durations can be read from the primary axis, whereas the timeto-ignition is shown on the secondary axis which only displays the first 30 seconds of combustion. The effect of moisture content on time-to-ignition is more evident, due to the 
presence of water that needs to evaporate before volatile burning can start. There is also a slight increase in the volatile burning time as the moisture content increases. Moisture content, however, does not have an effect on the char burning time. This is understandable, since at the onset of char burning, there is no more water or volatile matter present.

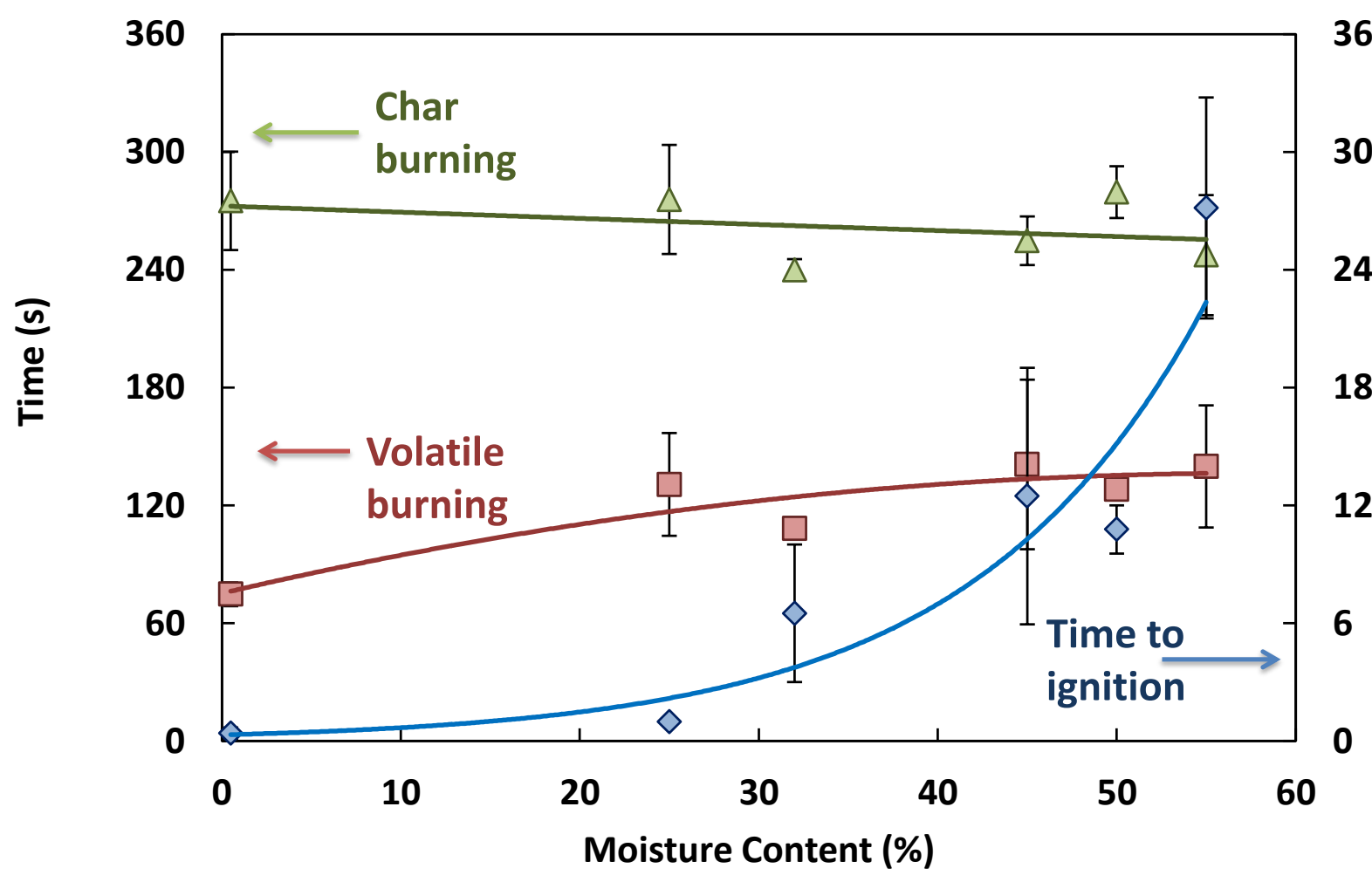

Figure 19. Combustion stages for pine during combustion at $800^{\circ} \mathrm{C}$.

\subsubsection{Comparison of Different Wood Species}

A series of experiments was conducted to find the effect of wood species and moisture content on combustion. Cubic samples with a constant volume of $2.2 \mathrm{~cm}^{3}(1.5 \mathrm{~cm} \times 1.2 \mathrm{~cm} \times 1.2 \mathrm{~cm})$ were prepared from different wood species. As summarized in Table 3, the results indicate that the combustion behaviour of biomass is highly dependent on the density of the wood species.

Hardwood samples have a higher density, thus taking a longer time to burn than softwood. The different combustion behaviour of hardwoods and softwoods is more evident for samples with higher moisture contents. When comparing the weight profile of different wood species with 
$40 \%$ moisture content, the decrease in the volatile burning rate is greater for the low density softwood (from 19.3 to $13.8 \mathrm{mg} / \mathrm{s}$ in the case of cedar), compared to that for the high density hardwood (from $7.7 \mathrm{mg} / \mathrm{s}$ to $6.3 \mathrm{mg} / \mathrm{s}$ in the case of maple). This can be explained by the dense structure of hardwoods where water vapour has less room to escape. Since the water vapour takes longer to exit the sample, the heat will also take longer to penetrate into the sample. Therefore lower volatile burning rates are observed for high moisture contents specially for higher density biomass samples. The weight change profiles and combustion stages information for the data shown in Table 3 can be found in Appendix 2.

Table 3. Combustion rate of different wood species

\begin{tabular}{|c|c|c|c|c|c|c|c|c|}
\hline \multirow{4}{*}{\multicolumn{2}{|c|}{ Wood Species }} & \multirow{4}{*}{$\begin{array}{l}\text { Density } \\
(\mathrm{g} / \mathrm{cm} 3)\end{array}$} & \multicolumn{6}{|c|}{ Combustion Stage Rate (mg/s) } \\
\hline & & & \multicolumn{2}{|c|}{ Time-to-ignition } & \multicolumn{2}{|c|}{ Volatile Burning } & \multicolumn{2}{|c|}{ Char Burning } \\
\hline & & & \multicolumn{6}{|c|}{ Moisture Content } \\
\hline & & & $0 \%$ & $40 \%$ & $0 \%$ & $40 \%$ & $0 \%$ & $40 \%$ \\
\hline \multirow{2}{*}{$\begin{array}{l}\overline{8} \\
8 \\
8 \\
\frac{8}{8} \\
\text { है }\end{array}$} & Cedar & 0.33 & 0 & 33.1 & 19.3 & 13.8 & 0.720 & 0.677 \\
\hline & Pine & 0.39 & 0 & 27.1 & 16.0 & 12.4 & 0.545 & 0.582 \\
\hline \multirow{3}{*}{ 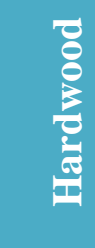 } & Poplar & 0.56 & 0 & 17.8 & 9.72 & 8.12 & 0.420 & 0.439 \\
\hline & Oak & 0.62 & 0 & 15.1 & 8.89 & 6.75 & 0.305 & 0.356 \\
\hline & Maple & 0.76 & 0 & 12.7 & 7.73 & 6.29 & 0.286 & 0.339 \\
\hline
\end{tabular}

\subsubsection{Saw Dust Combustion}

Saw dust is a common feedstock for biomass boilers in the pulp and paper industry. For this reason the effect of moisture content on saw dust combustion with particle size range $0.42 \mathrm{~mm}$ to $1.12 \mathrm{~mm}$ was studied. The results were similar to that of wood chips: increasing the moisture 
content has a significant effect on time to ignition or drying, since the water contained in the sample needs to evaporate in order for the sample to reach a minimum temperature of $250^{\circ}$ $300^{\circ} \mathrm{C}$ and for combustion to start. As discussed in Section 3.2.2, the maximum moisture content for saw dust samples was $80 \%$ which was higher than the other samples tested in this study. It was discussed previously that for pine wood chips, the time-to-ignition showed an exponential increase with increasing the moisture content up to $40 \%$ which is similar to that of saw dust as shown in Figure 20 and 21. Moreover, for saw dust samples with more than $40 \%$ moisture content, the time-to-ignition continues to increase exponentially. Volatile burning did not increase as much for moisture contents higher than $50 \%$. It seemed that for a furnace temperature of $800^{\circ} \mathrm{C}$, once volatile burning starts, the duration of the flame for increasing moisture contents increases slightly. This is understandable since the volatile content of the samples were equal and therefore at the commencement of combustion, all these volatiles exit in form of a flame.

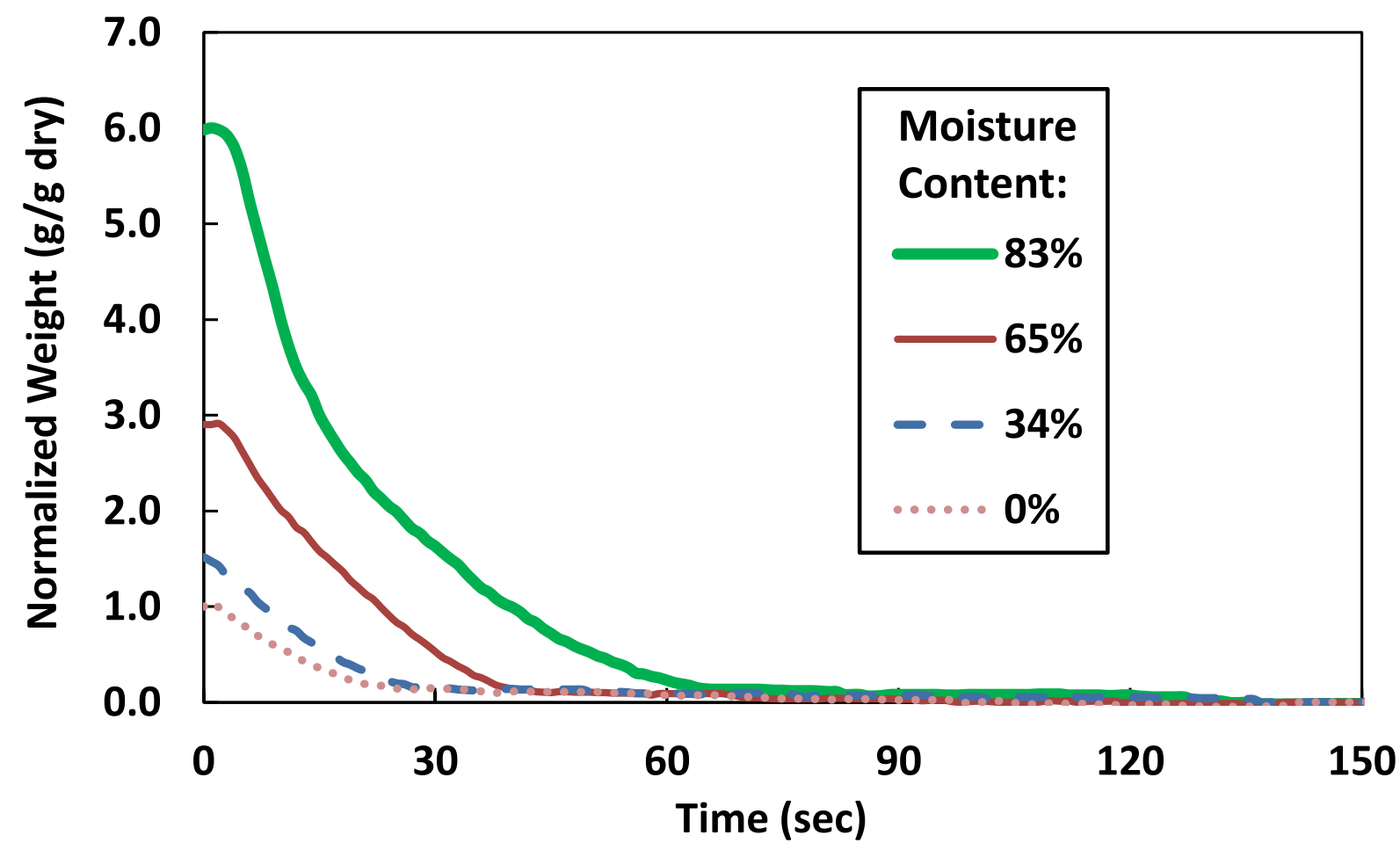

Figure 20. Weight change profile for saw dust combustion at $800^{\circ} \mathrm{C}(0.2 \mathrm{~g}$ dry sample $)$ 


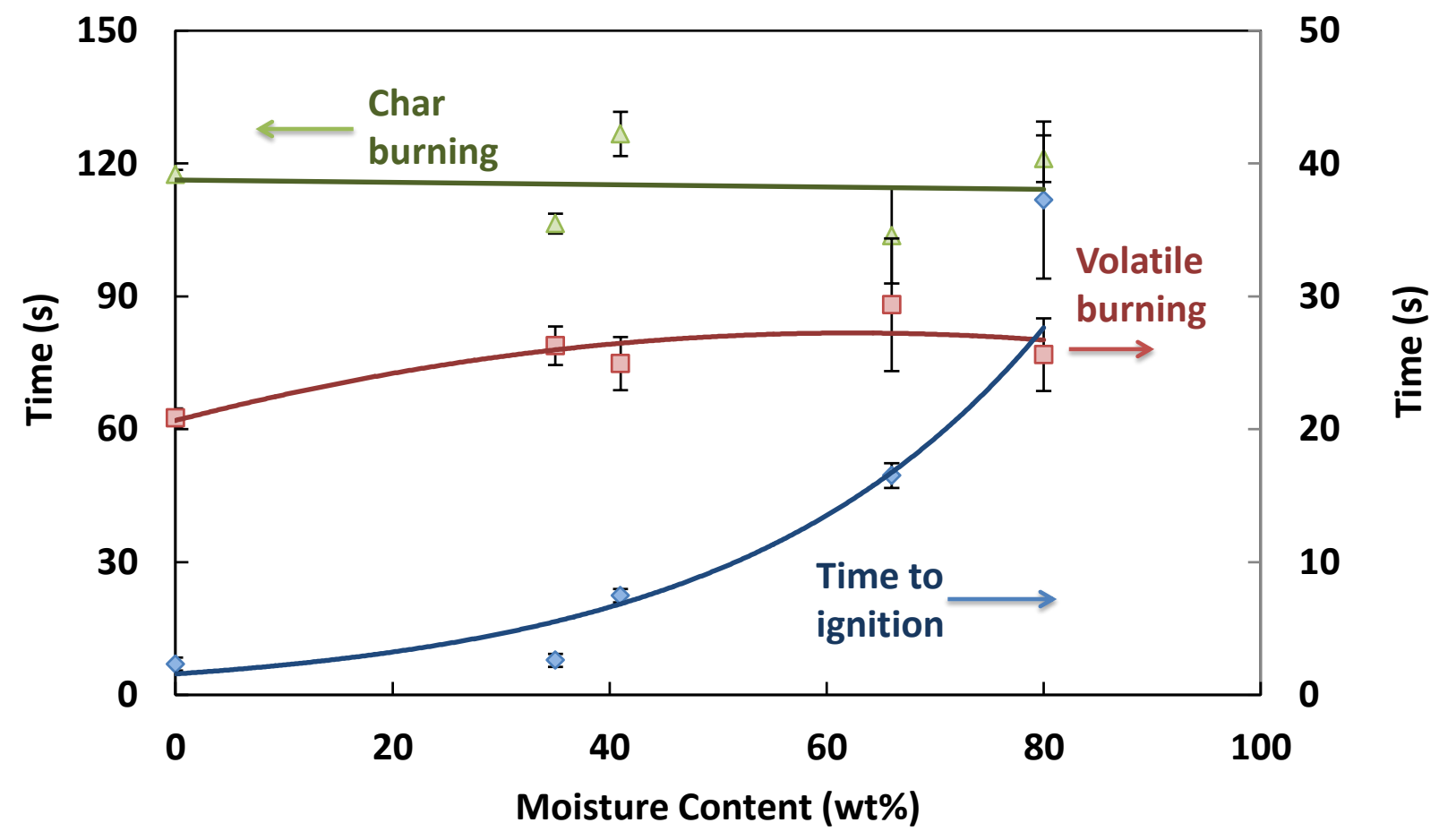

Figure 21. Combustion stages for saw dust combustion at $800^{\circ} \mathrm{C}(0.2 \mathrm{~g}$ dry sample $)$

\subsubsection{Water Vapor Exit during Combustion}

Since water is stored in the vessels of the cellular structure of the wood (Figure 22), during drying, it vapourizes and escapes through the vessel openings on the transverse surface more readily than through vessel walls on the radial and tangential surfaces which was discussed in detail in Chapter 3. Thus, per surface area, wood dries more readily from the cross-section than from the side of the trunk or branch. This preferential release of water from the transverse surface of wood was observed in all combustion tests in this study.

An example of this is shown in Figure 23 which compares the combustion behaviours between softwood and hardwood samples containing 40\% moisture. Thirty seconds (00:30) after the softwood sample was loaded into the TG combustor at $800^{\circ} \mathrm{C}$, the tangential and radial surfaces of the softwood sample turned black with yellow flames around them. The transverse surface, however, appeared to remain intact, still showing its original woody texture. The sample at this 
point appeared to resemble the cross section of a coffee crisp bar that had been split in half. This "coffee-crisp" effect was presumably caused by the continuous release of water vapour from the transverse surface keeping the surface temperature below the ignition point of the volatiles. As the rate of water vapour release decreased with time, the transverse surfaces became darker and eventually ignited into yellow flames after one minute (1:00), while the yellow flame on the tangential/radial surfaces were weakening. After 1.5 minutes (01:30), flames were observed only on the transverse surfaces. Similar results were observed for the hardwood sample, except that the "coffee crisp" effect was not as clear as that observed in the softwood sample. This is understandable since hardwood is denser and contains less water in its vessels than softwood.

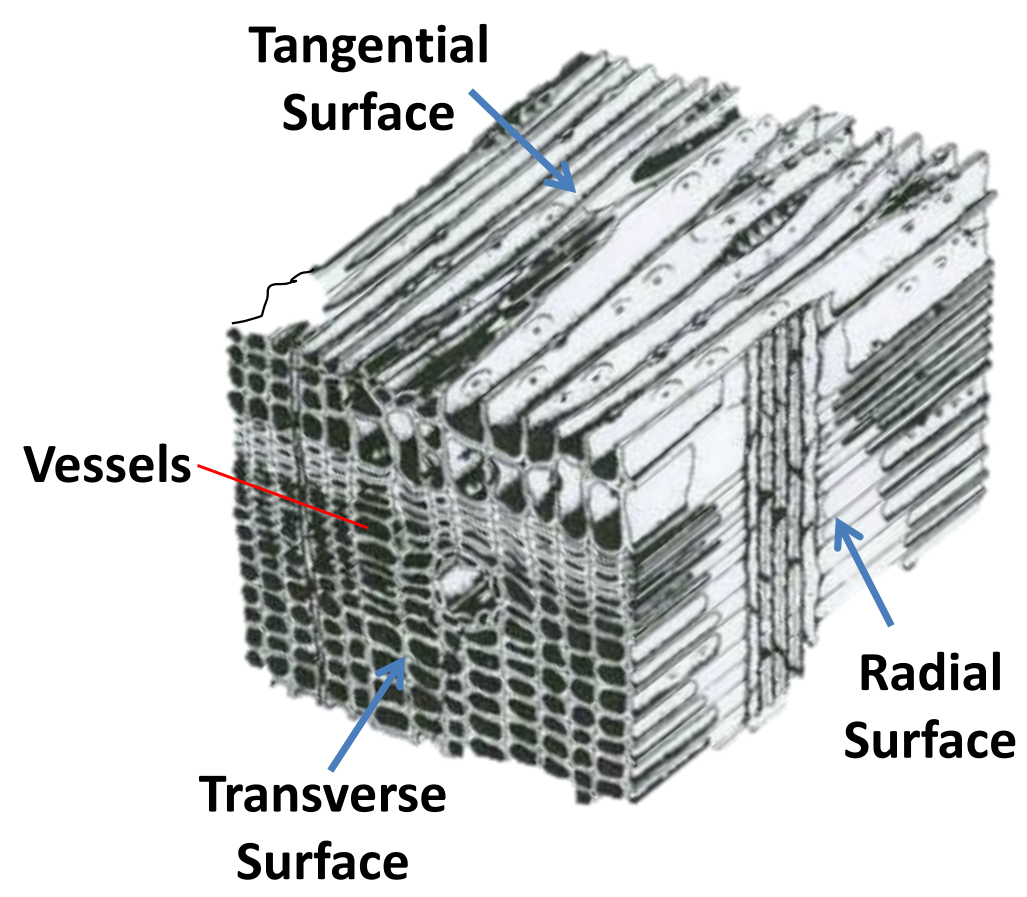

Figure 22. Wood cellular structure [22] 

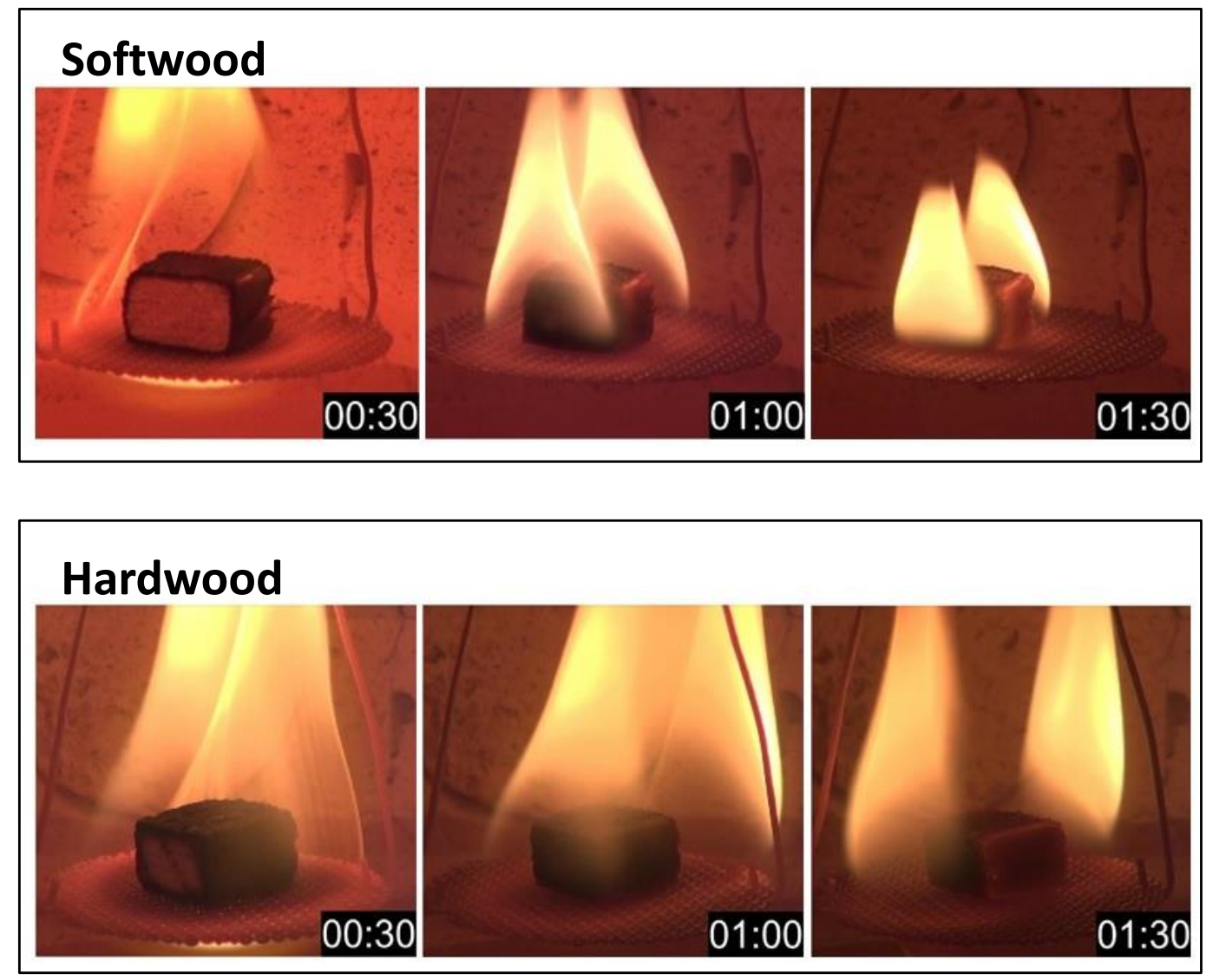

Figure 23. Flame distribution of softwood and hardwood during volatile burning (Furnace temperature $=800^{\circ} \mathrm{C}$ )

The surface of the sample must reach about $300^{\circ} \mathrm{C}$ in order for volatile burning to occur. As volatiles burn, the surface temperature of the sample increases, the heat continues to transfer to the interior of the particle, further increasing its temperature, and causing volatile burning. Due to the large temperature gradient between the sample surface and interior, particularly for samples with high moisture contents, drying and volatile burning often overlap [17]. While volatile burning occurred on the radial and tangential surfaces, drying continued to occur in the middle of the sample and on the transverse surface, keeping its temperature low. In other words, while one part of the sample is drying, the other part has already undergone volatile burning. This means that overall, drying and volatile burning can occur simultaneously, particularly for samples with high moisture contents. 


\subsubsection{Effect of Furnace Temperature}

\subsubsection{Oakwood Chips}

In biomass boilers, the combustion heat is sustained by continuously burning the biomass feedstock. Burning feedstock with high moisture contents will inevitably lower the furnace temperature, significantly reducing combustion and steam production efficiencies of the boiler. In this study, only a fixed amount of the sample was used and the combustion was carried out in the TG combustor where the temperature was well controlled by electrical heaters. The results obtained, therefore, may not be applicable to the actual boiler environment. In order to simulate the effect of temperature fluctuations in biomass boilers, a set of experiments was carried out to examine the effect of moisture content on combustion at different furnace temperatures. The results are summarized in Figure 24.

At all temperatures examined, the time-to-ignition appeared to exponentially increase with an increase in moisture content (Figure 24a). The increase, however, was more dramatic at a lower furnace temperature, particularly at $500^{\circ} \mathrm{C}$. The volatile burning time (flame duration) also increased as the furnace temperature decreased. Note however that the volatile burning time at $500^{\circ} \mathrm{C}$ was longer than that at $700^{\circ} \mathrm{C}$ and $800^{\circ} \mathrm{C}$, but was shorter than that at $600^{\circ} \mathrm{C}$ (Figure $24 \mathrm{~b}$ ). This shorter volatile burning time is possible, since at $500^{\circ} \mathrm{C}$, the temperature was sufficiently low that during the time-to-ignition stage, some volatiles might have been released without burning. Similar to the results shown in Figure 19 and Figure 21, the char burning duration was not affected by the moisture content. However, char burning lasted longer as the furnace temperature decreased (Figure 24c).

For dry samples $\left(0 \%\right.$ moisture content) and at furnace temperatures higher than $500^{\circ} \mathrm{C}$, the heat provided by the combustion is sufficient to produce similar weight loss profiles (Figure 25). However, for samples with $40 \%$ moisture content, drying and volatile burning are clearly influenced by the surrounding temperature (Figure 26). The weight loss profile undergoes a change in slope the moment the sample ignites (point $\mathrm{A}$ on the $600^{\circ} \mathrm{C}$ curve, for example). The lower the surrounding temperature, the longer it takes the sample to ignite, or for this break point to appear on the curve. Beyond this point, the slope of the curve is almost the same. This is likely because the ignition and the subsequent burning of the volatile matter resulted in the same 
temperature at the sample surface, despite the difference in the surrounding furnace temperature. At $400^{\circ} \mathrm{C}$, the change in slope occurs after 4 minutes from the insertion of the sample into the furnace. This is an indication that the combination of low furnace temperature and high moisture content causes the surface temperature of the sample to reach the auto-ignition temperature of biomass (approximately $250^{\circ} \mathrm{C}-300^{\circ} \mathrm{C}$ ) when most of the volatile content has already escaped from the sample and due to the dilution of the vapor phase with water, there is simply not enough fuel for ignition to occur and for a flame to form. Therefore at this furnace temperature, no flame is formed for samples with $40 \%$ moisture content. The still-images for combustion experiments related to Figures 25 and 26 can be found in Appendix 3. 
(a)

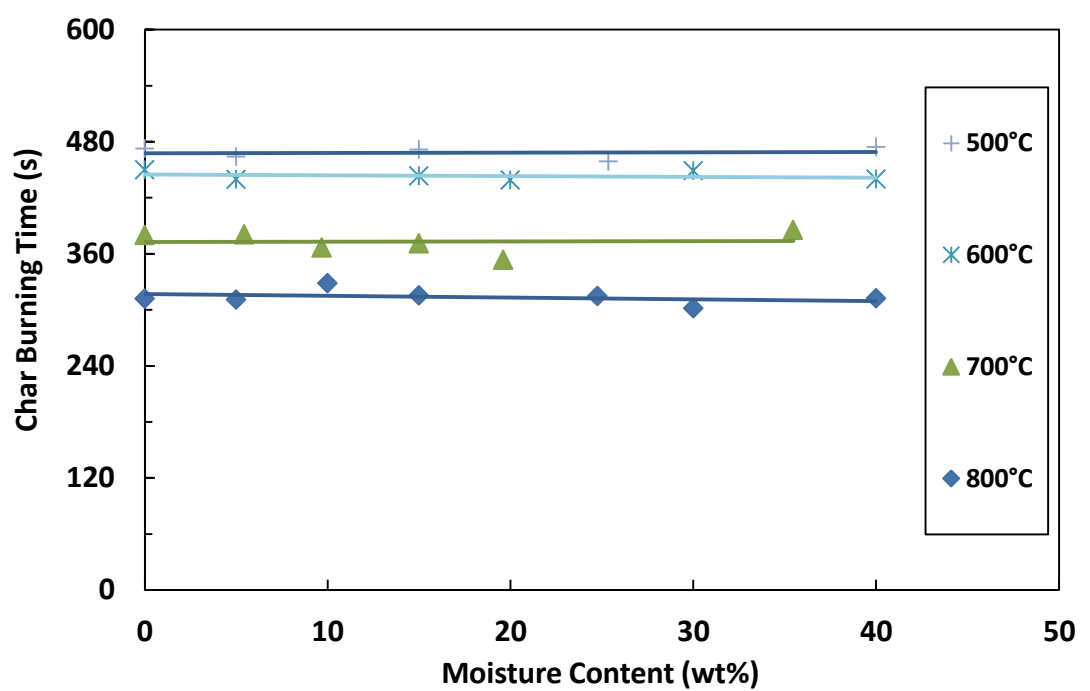

(b)

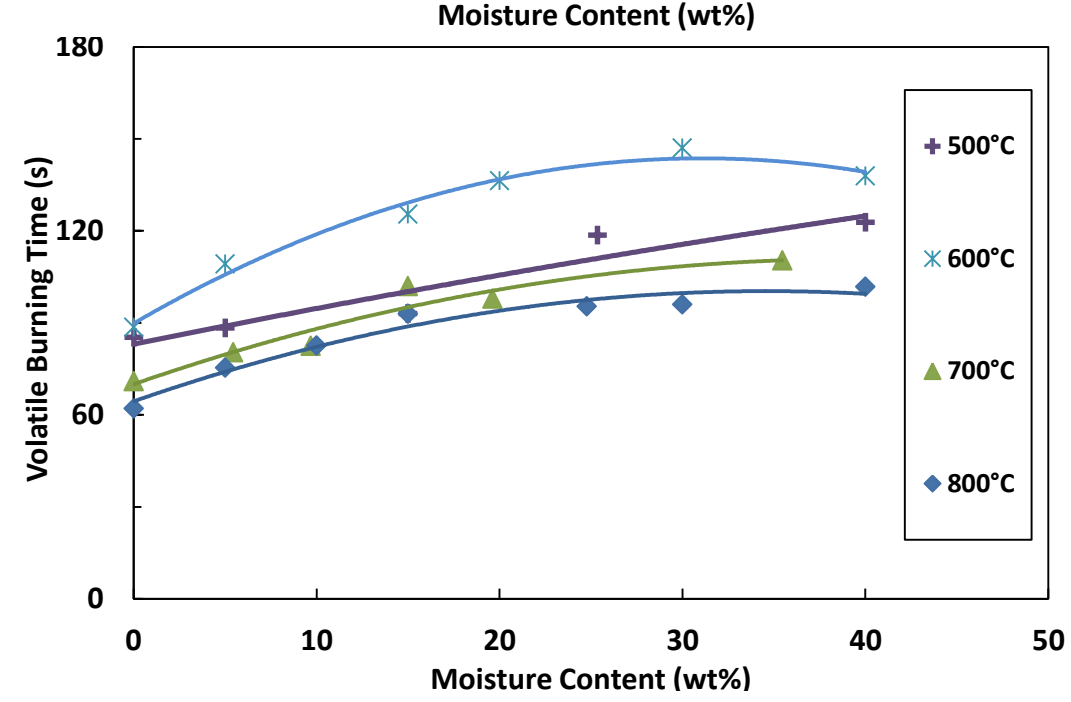

(c)

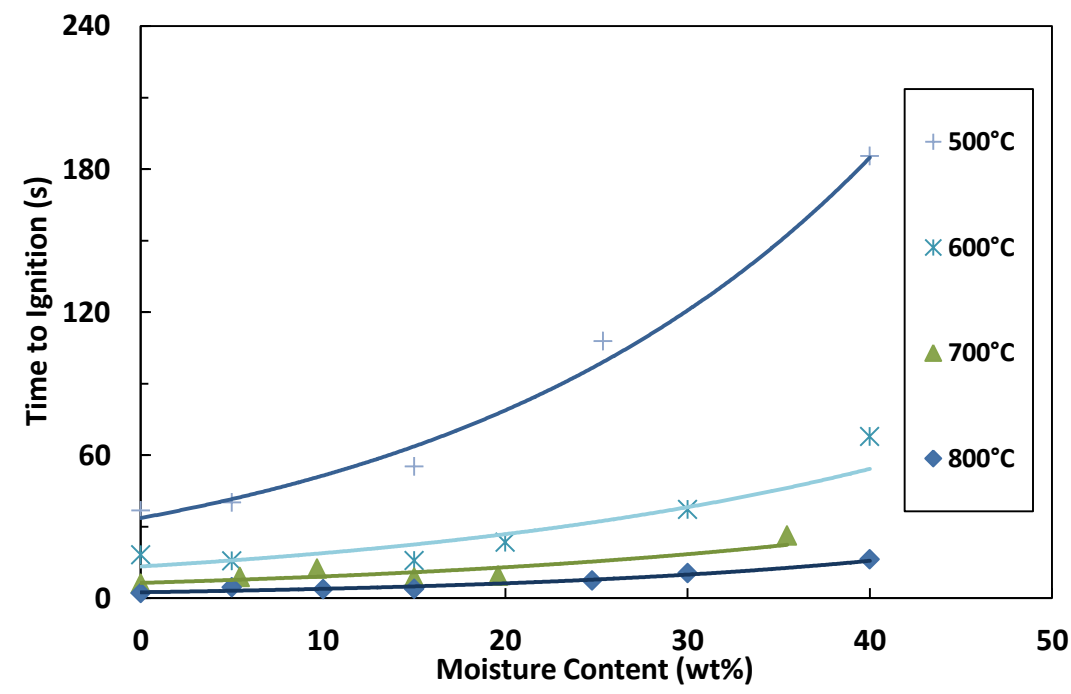

Figure 24. Effect of moisture content and furnace temperature on combustion of oak (1.34 g dry sample) 


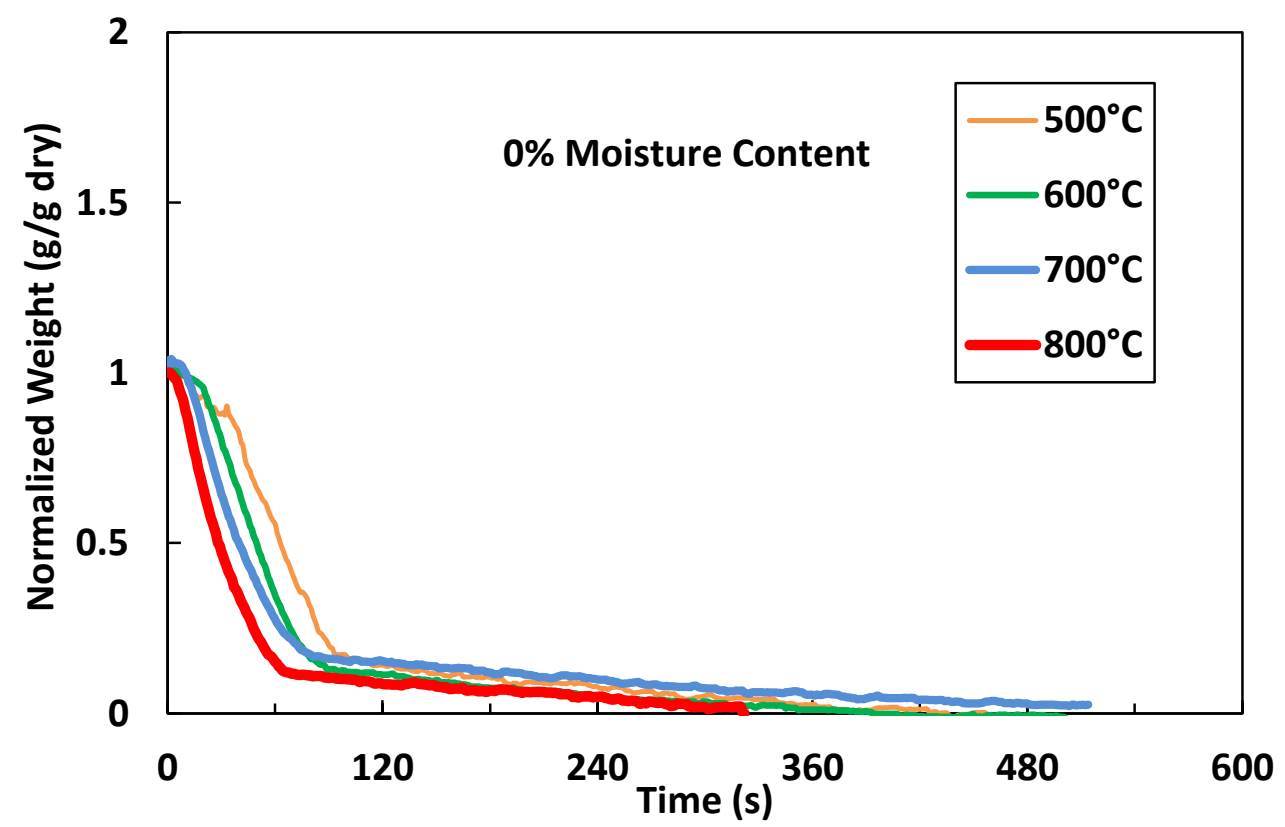

Figure 25. Weight profile for combustion of oak with $0 \%$ moisture content (1.34g dry)

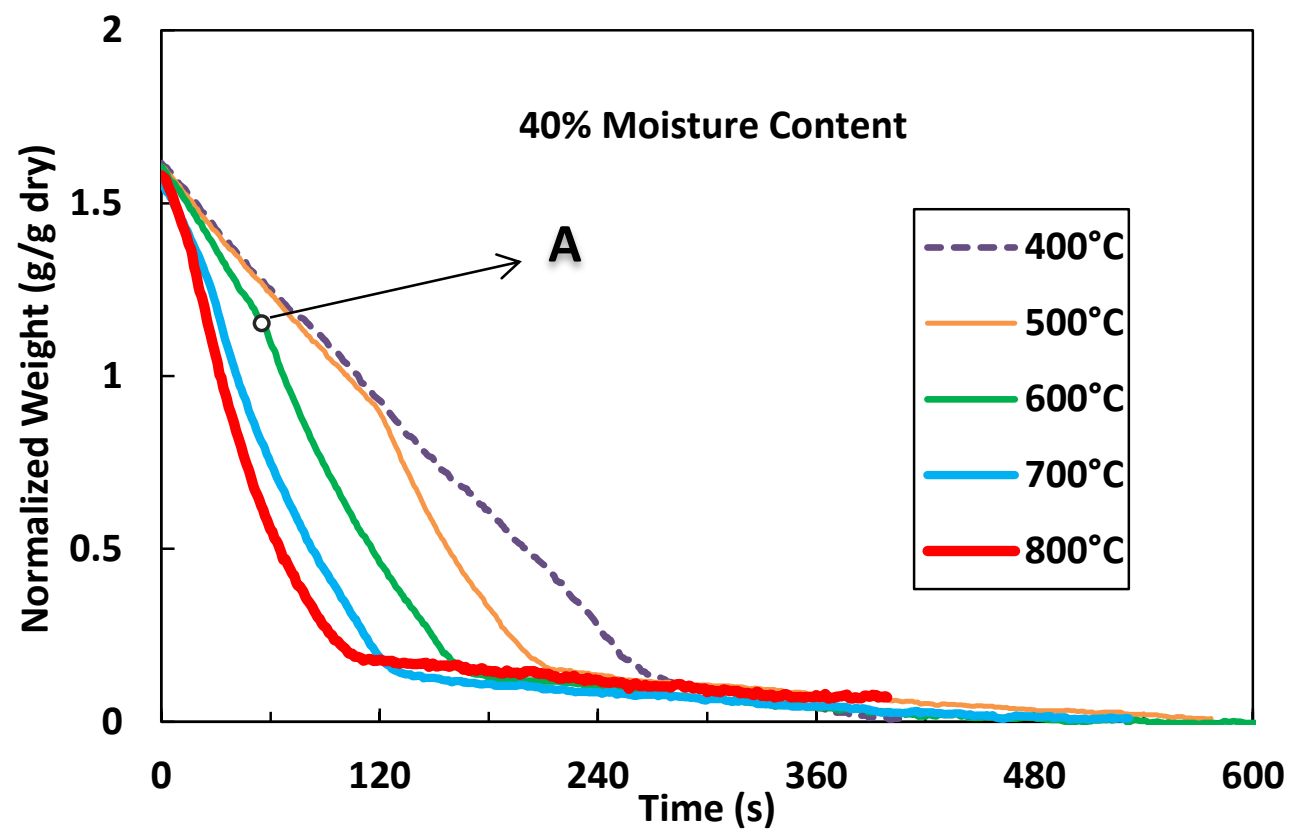

Figure 26. Weight profile for combustion of oak with $40 \%$ moisture content (1.34g dry) 


\subsubsection{Freshly Cut Branches}

The combustion of freshly cut maple branches at different furnace temperatures was studied and the moisture content of fresh maple branches was found to be $30 \%$. The results shown in Figure 27 and tests were performed at $800^{\circ} \mathrm{C}, 600^{\circ} \mathrm{C}$, and $400^{\circ} \mathrm{C}$. The weight change profiles indicate similar behaviour to wood chips discussed in the previous section.

The main driving force for the initiation of combustion in the experiments is the temperature gradient between the surface of the sample and the surrounding. Therefore, when the furnace temperature is set at a higher value, combustion takes place faster due to the higher temperature gradient between the sample and the surrounding and with a stronger driving force.

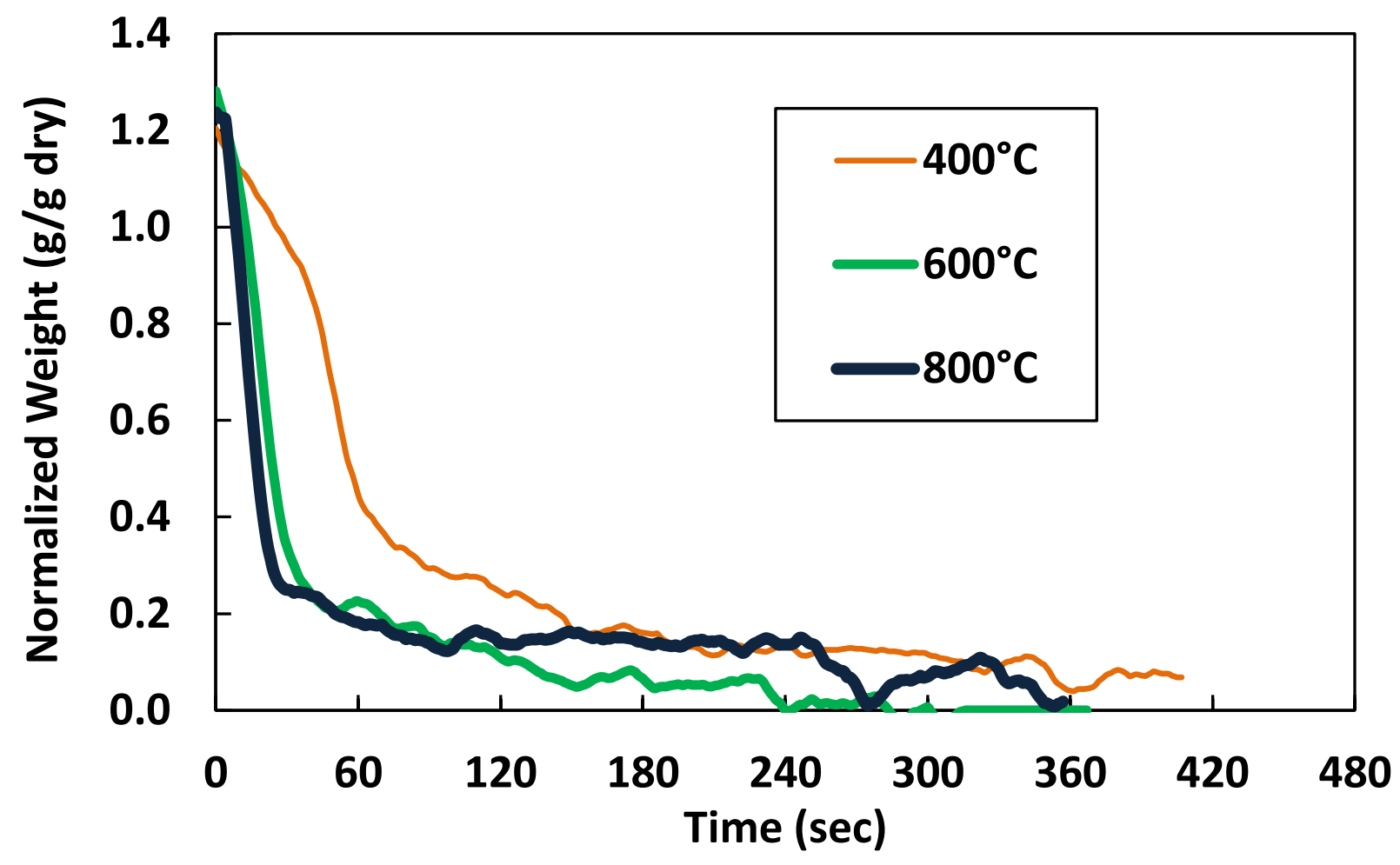

Figure 27. Combustion of freshly cut maple branch (30\% moisture content) 


\subsubsection{Pine Bark}

In industrial biomass boilers, the feedstock usually consists of wastewood or bark. To study the differences between combustion of wood and bark, a series of experiments was conducted for combustion of jack pine bark with different moisture contents at different furnace temperatures and compared with pine wood chips. Table 4 shows the differences in composition of pine bark and pine wood calculated from the weight change profile at different combustion stages and it shows that bark has less volatiles and more ash and fixed carbon compared to pine wood.

Table 4. Composition of pine bark and wood

\begin{tabular}{|c|c|c|}
\hline Proximate Analysis & Pine Bark & Pine Wood \\
\hline Ash content (wt \%) & 1.6 & 0.2 \\
\hline Volatile matter (wt \%) & 72.0 & 88.9 \\
\hline Fixed carbon (wt \%) & 26.4 & 10.9 \\
\hline
\end{tabular}

Figure 28 shows time lapse images for combustion of bark with $40 \%$ moisture content at $800^{\circ} \mathrm{C}$. the time interval between each frame is not constant to show the onset of different combustion stages. It can be seen that the time-to-ignition stage takes 15 seconds(00:00 to 00:15), the volatile burning stage takes almost one minute $(00: 15$ to $1: 20)$ and the char burning stage lasts almost 5 minutes $(1: 20$ to $6: 00)$. In frames $(00: 16),(00: 25)$ and (00:30) small pecies are seen flying out of the sample in form of sparks. This is the main difference observed between pinewood and pine bark combustion. Due to the layered structure of the bark, as combustion progresses, the layers expand and ocassionaly sparks fly out of the sample which can cause the sample to shift and fall off the crucible. The expansion of the layers can be seen by comparing frame (00:00) with frame (00:20) during volatile burning or frame (2:01) during char burning where the edge of each layer seems to be glowing brighter than the rest of the sample. 

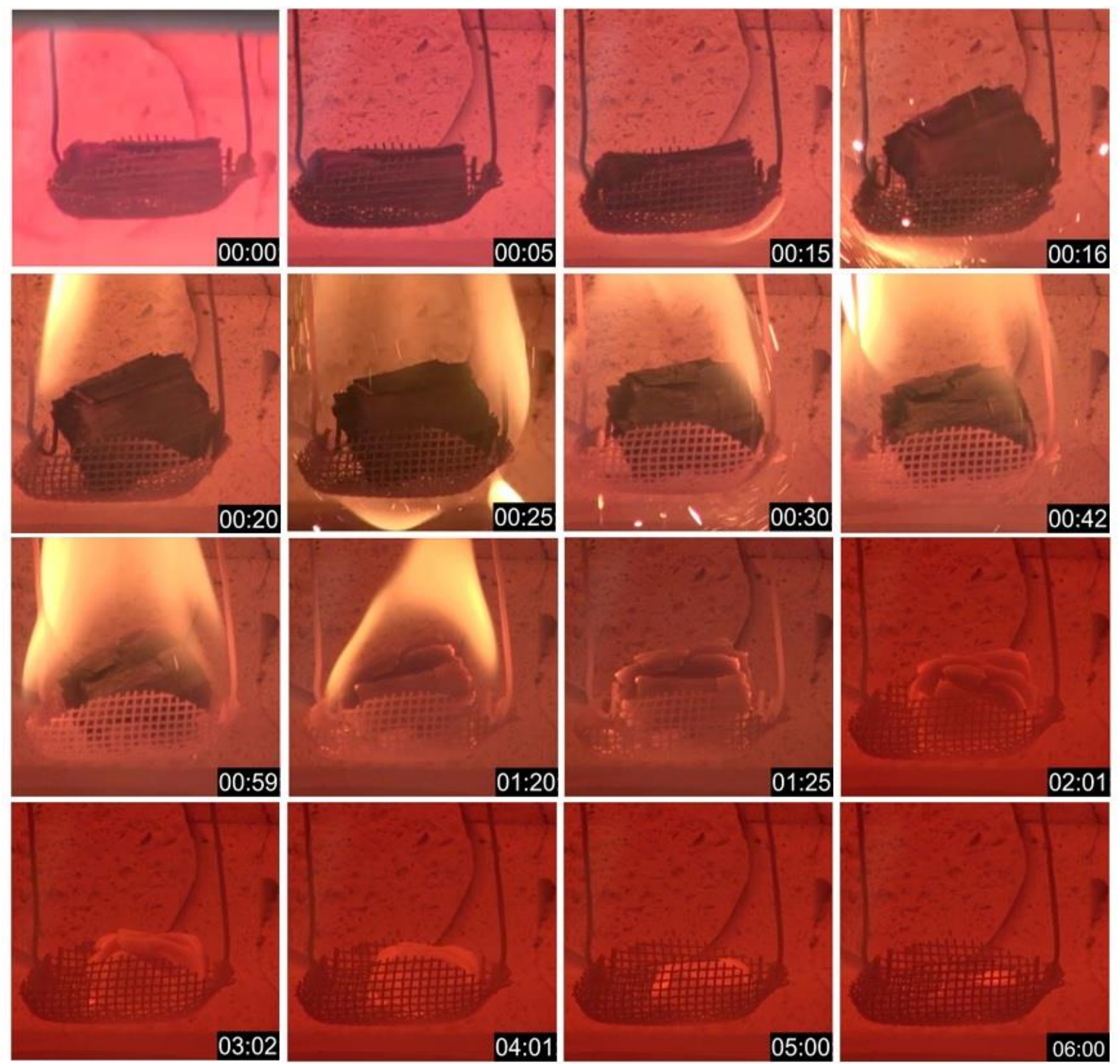

\section{Figure 28. Combustion of pine bark with $40 \%$ moisture content at $800{ }^{\circ} \mathrm{C}$}

The effect of moisture content and surrounding temperature on combustion of bark is very similar to that of wood as discussed in the previous section. That is when the moisture content is higher than $40 \%$ and the furnace temperature is lower than $500^{\circ} \mathrm{C}$, the flame duration is shorter which suggests that the volatiles escape without burning. Figure 29 shows the effect of furnace temperature and moisture content on combustion stages. As seen in Figure 29a, with the decrease of furnace temperature and increase in moisture content, the time to ignition stage increases 
exponentially. In Figure 29b, the changes in volatile burning can be seen where for $500^{\circ} \mathrm{C}$, the volatile burning duration decreases indicating "loss" of volatiles without burning. In Figure 29c, it can be seen that char burning is not affected by changes in moisture content. Figure 30 and 31 show the weight change profiles for different furnace temperatures which is similar to Figures 25 and 26 for combustion of wood chips. 
(a)

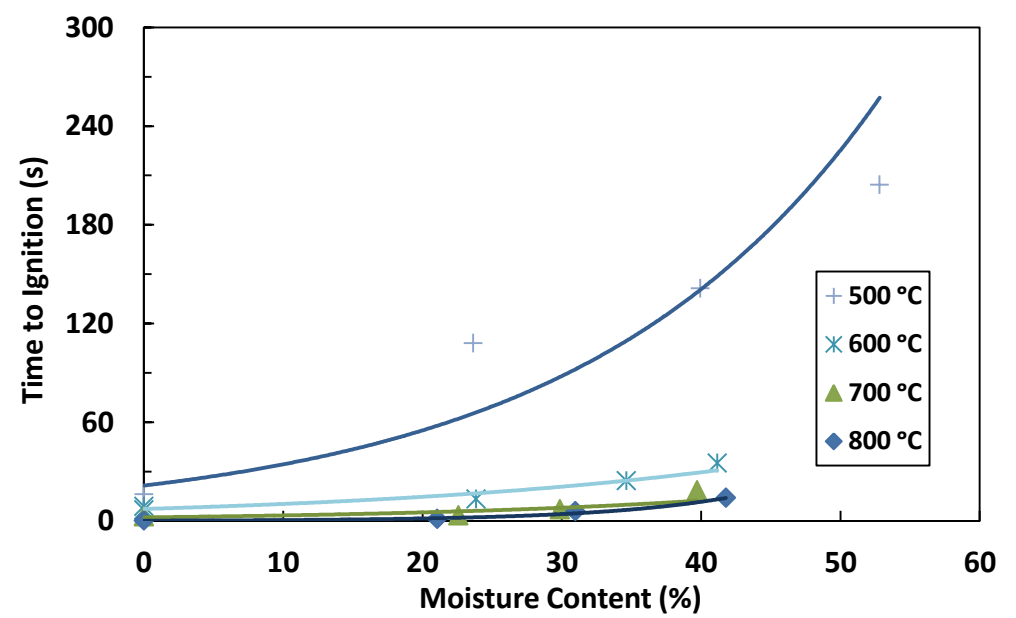

(b)

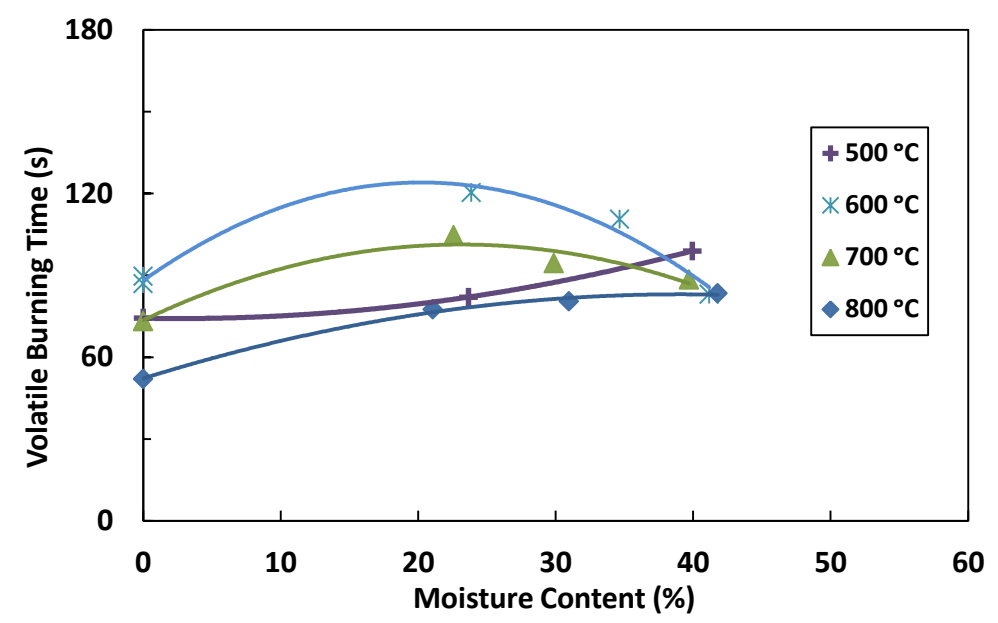

(c)

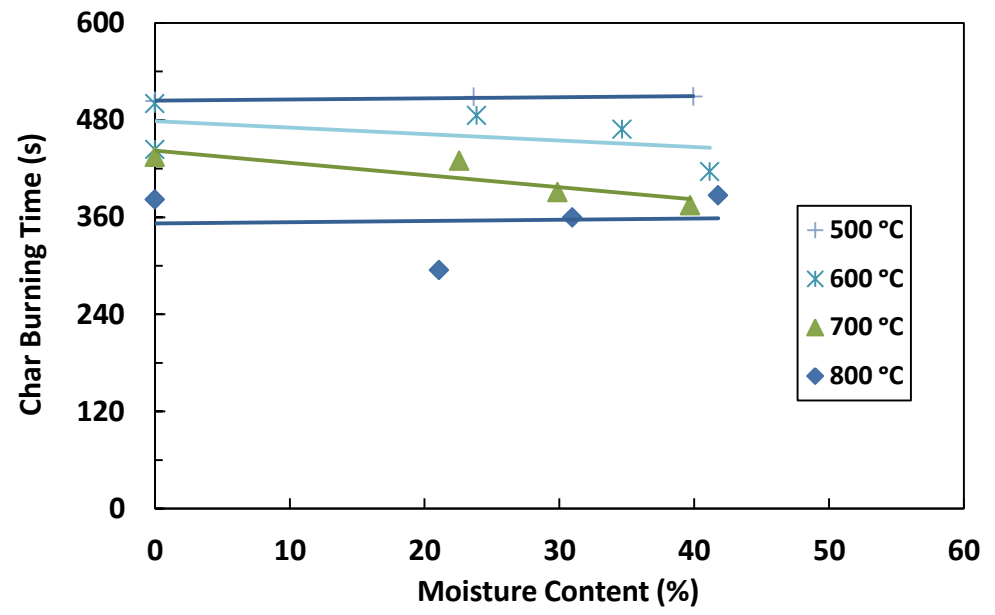

Figure 29. Effect of moisture content and furnace temperature on combustion of pine bark (1g dry sample) 


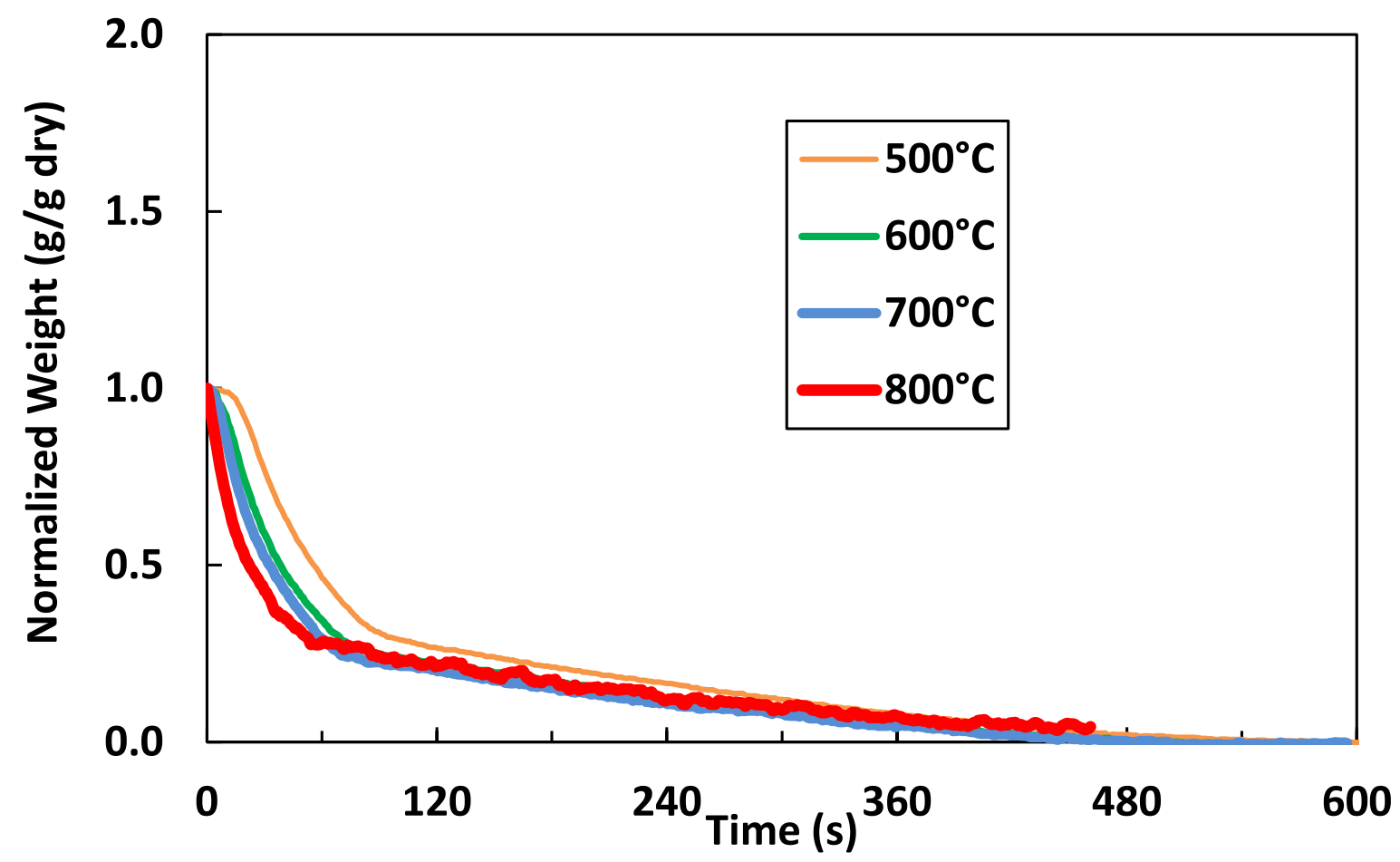

Figure 30. Weight profile for combustion of pine bark with $0 \%$ moisture content (1g dry)

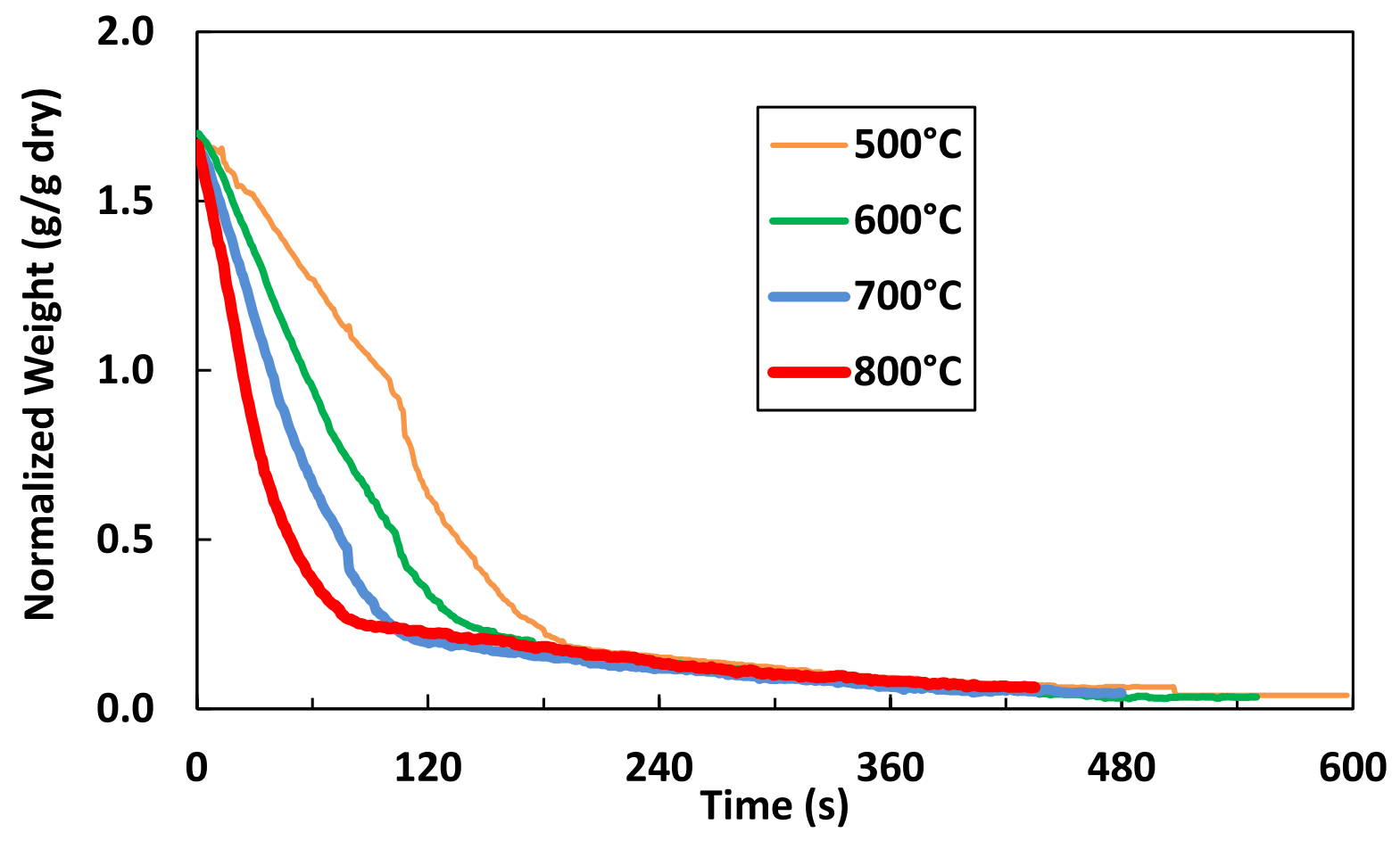

Figure 31. Weight profile for combustion of pine bark with $40 \%$ moisture content (1g dry) 


\subsubsection{Implication}

The average moisture content of the feedstock burned in biomass boilers in pulp mills is typically about $40-50 \%$ and the average furnace temperature is about $800^{\circ} \mathrm{C}$. Results obtained from this study imply that in biomass boiler operation, if the moisture content of the feedstock suddenly increases due to rain, or due to its mixing with wetter feedstock piles (old wood waste, biosludge etc.), the furnace temperature will decrease. This, in turn, will suppress the combustion of the wet feedstock, further decreasing the furnace temperature. The downward spiral effect will lower the steam production capacity of the boiler, and lead eventually to a boiler blackout, unless the biomass feed rate is significantly reduced, the wet feedstock is mixed with drier piles of feedstock to reduce the moisture content, and/or the auxiliary fuel (natural gas and fuel oil) flow rate is increased to keep the furnace temperature high and to maintain the steam production on target.

It was discussed in previous sections that for a decrease in furnace temperature, the volatile burning duration increased. For samples that contained $40 \%$ moisture however, the volatile burning time at $500^{\circ} \mathrm{C}$ was found to be shorter than that at $600^{\circ} \mathrm{C}$ (Figure 24b). This shorter volatile burning time implies that some volatiles might have "escaped" without burning during the time-to-ignition stage. The unburnt volatile organic compounds (VOC) would travel up the boiler and exit via the stack. This implies that the combined effect of the high moisture content in feedstock and the low furnace temperature can result in increased concentrations of combustibles and volatile organic compound (VOC) in the biomass boiler flue gas which results in loss of the net energy released from combustion of biomass. As a result of less heat being released, the furnace temperature would decrease further as described above and the operation of the biomass boiler would not be self-sustained.

Figure 32 demonstrates the spiral cycle leading to boiler blackout. The high moisture content feedstock requires a longer drying time which needs more heat for evaporation of water, this leads to less heat being available in the furnace area and therefore a decrease in the furnace temperature. Once the furnace temperature drops, the operator would increase the feed rate to compensate and keep the steam production on target. Since the feedstock already has a high 
moisture content, more of the wet material is introduced into the boiler which requires more heat for drying. This will further decrease the furnace temperature and therefore the steam production and the operator will once again increase the feed rate to compensate. This will continue until the temperature of the furnace is not high enough for the volatile content to burn off completely and release their energy content. Therefore VOCs are formed and exit with the flue gases and the temperature of the furnace will further decrease until the fire is completely out and the boiler needs to be started up again with the help of fossil fuel burners.

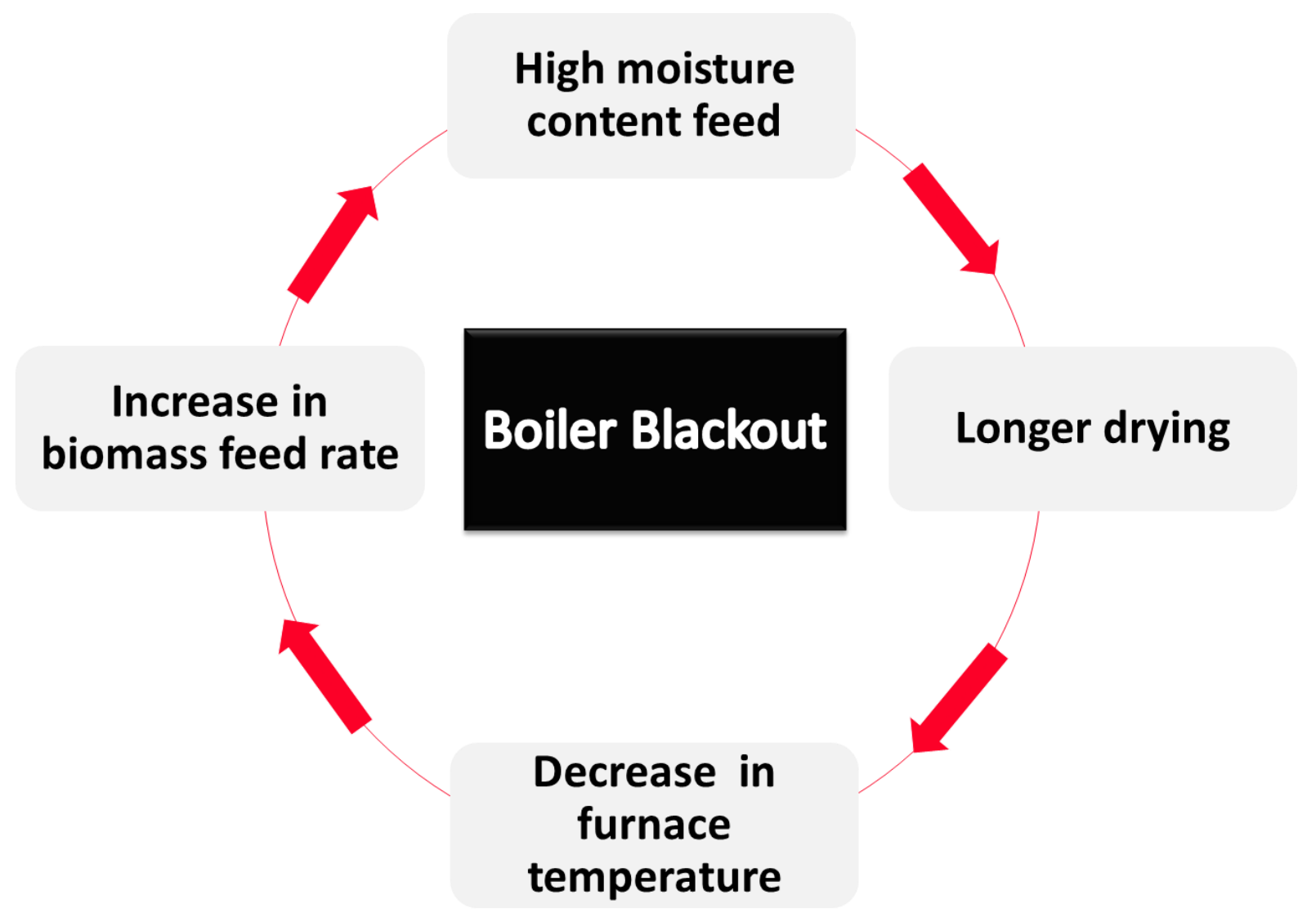

Figure 32. Spiral effect leading to boiler blackout 


\section{Part II: Field Studies}

The results of the laboratory experiments demonstrate the effect of moisture content on the combustion of a single particle in a closed system. Biomass boilers at pulp mills however, operate on a continuous basis. Therefore the effect of moisture content needs to be looked at from a wider perspective.

The main purpose of this study is to better understand the effect of changes in moisture content on the operation of biomass boilers and to develop viable detection and control strategies for maintaining a stable boiler operation and steam production. For this purpose, the results of the laboratory experiments needed to be paired with field studies and data analysis of industrial scale biomass boilers and together relevant conclusions can be made.

The field studies were carried out for biomass boilers at three different pulp mills. With the help of process engineers at each mill, the operation of each boiler was investigated and 2 years of data for the relevant operating parameters were collected and analyzed. 
Chapter 5

Mill Visits

\section{$5 \quad$ Mill Visits}

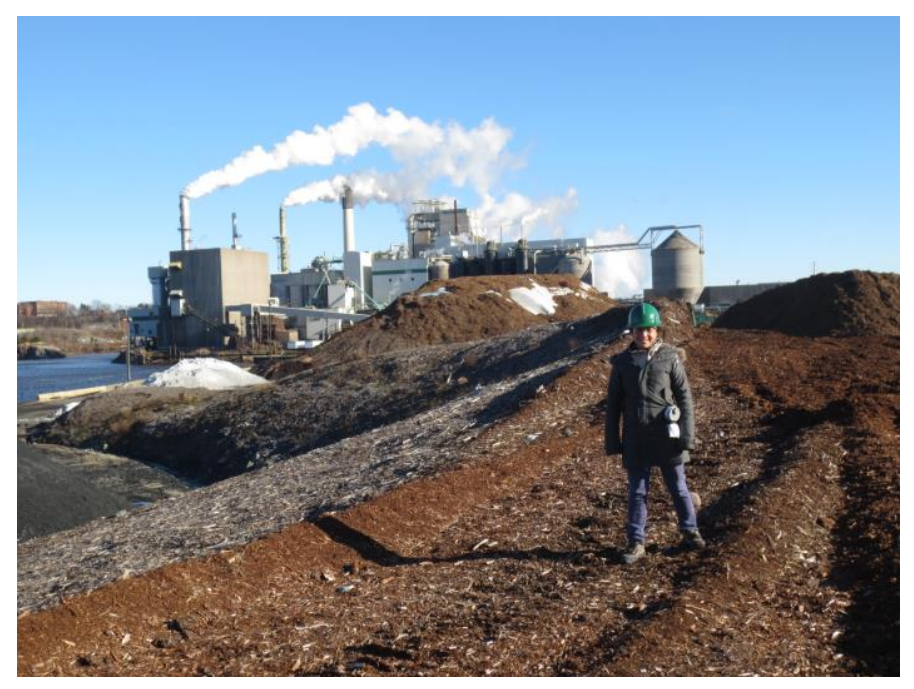

(a)

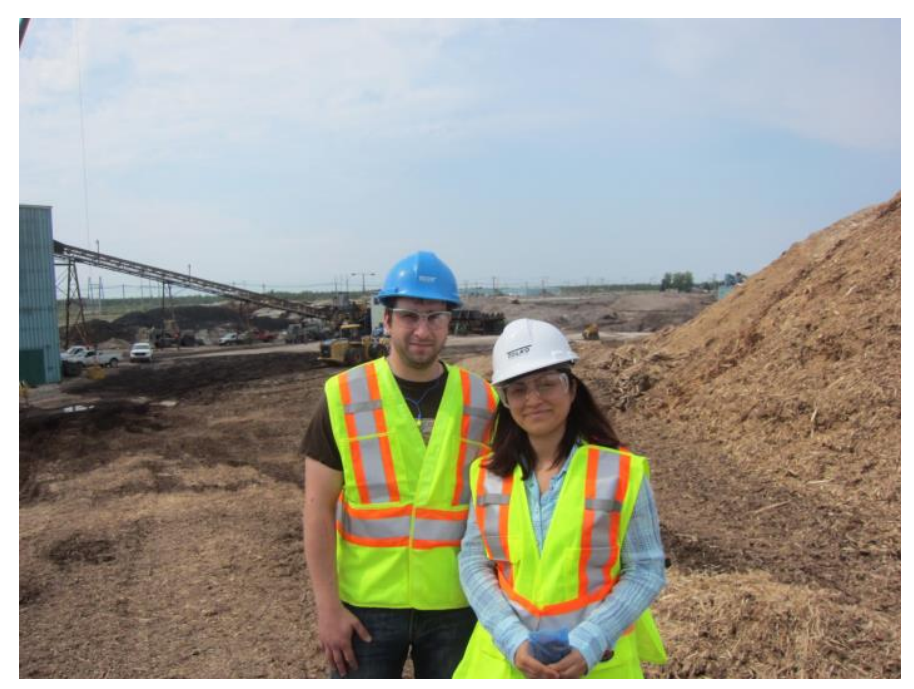

(b)

Figure 33. Mill visits a) Mill A and b) Mill B 


\subsubsection{Mill A}

The biomass boiler at mill A is a Babcock \& Wilcox boiler built in 1984. The grate is a pinhole vibrating grate. The boiler has four burners which run on either natural gas or fuel oil when necessary. The boiler can produce up to $102 \mathrm{~T} / \mathrm{h}$ of $6205 \mathrm{kPa}$ steam. On average $30 \mathrm{~T} / \mathrm{h}$ of bark are fed to the boiler. The undergrate air has two sections on the north and south sides, each of which is divided into three sections to allow adjustment of the undergrate air for maximum combustion and distribution on the grate. The lower furnace temperature is $600^{\circ}-800^{\circ} \mathrm{C}$. Figure 34 shows a schematic of the biomass boiler at mill A.

The types of biomass burnt in the boiler are a mixture of the piles of biomass stored outside which are divided into two piles, old and new. The old bark is almost 40 years old (heritage pile) and the new bark is purchased on a regular basis. It is also mixed with the knotter rejects coming from the uncooked chips in the digester and the chip rejects from the screens before the digester.

In the winter time, the smaller particle sizes for the bark feed tend to freeze together and create plugging problems in the fuel chute and a high moisture content in the boiler. One indication of

high moisture content in the boiler is fluctuations of the lower furnace temperature, or the ID fan outlet temperature or the stack temperature. 


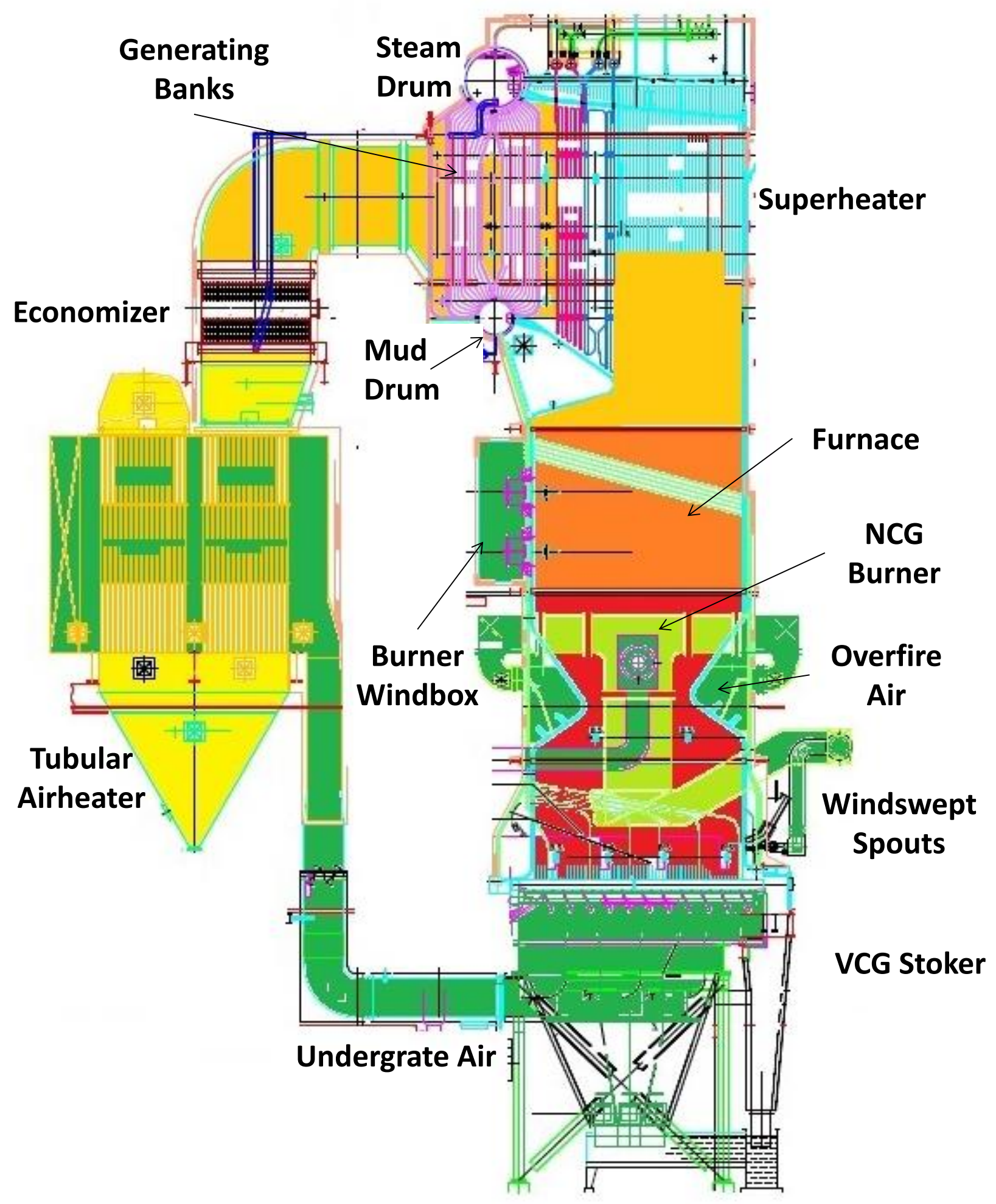

Figure 34. Schematic diagram of biomass boiler at mill A 


\subsubsection{Mill B}

The biomass boiler at Mill B is very similar to that of Mill A. It is also a stoker grate type boiler with pinhole grates in order to allow the distribution of combustion air on the grate. The biomass boiler at mill B produces an average of $120 \mathrm{~T} / \mathrm{h}$ steam with a temperature of $442{ }^{\circ} \mathrm{C}$ and pressure of $6400 \mathrm{kPa}$.

\subsubsection{Mill C}

The stoker grate type boiler at Mill $\mathrm{C}$ has a sloping grate for drying the feedstock in the boiler. The wood waste enters the boiler and is piled on the drying slope of the grate and then moves to the flat area of the grate where combustion takes place. Also, mill $\mathrm{C}$ injects secondary and tertiary air into the boiler at locations above the grate in order for the volatiles to burn off completely. The average steam production is $130 \mathrm{~T} / \mathrm{h}$ with a temperature of $400^{\circ} \mathrm{C}$ and pressure of $4500 \mathrm{kPa}$. Mill $\mathrm{C}$ is the only mill which measures the moisture content of the feedstock and these data were used to double check the calculations in the data analysis section.

\subsubsection{Total Heat Release Calculations}

Table 5 shows the effect of moisture content on the total heat released from biomass combustion. The calculations are done for $1 \mathrm{~g}$ of dry biomass sample with moisture content ranging from $0 \%$ to $83 \%$. For higher moisture content values, the heat required for drying is higher than the heat released from combustion resulting in a negative net heat release. The second column of the table shows the total weight of biomass sample which includes the dry biomass weight as well as the weight of water and the third column shows the amount of water only. The fourth column shows the sensible heat of water which is the amount of heat required to raise the temperature of the water inside the biomass sample from ambient temperature, assumed to be $25^{\circ} \mathrm{C}$, to the evaporation temperature of water, which is $100^{\circ} \mathrm{C}$ at atmospheric pressure. The heat capacity of liquid water used for the calculation of the sensible heat is $4.19 \mathrm{~kJ} / \mathrm{kg} \mathrm{K}$. The fifth column of the table shows the latent heat of evaporation for water to undergo a change from liquid state to vapor state. The specific latent heat of water used here is $2270 \mathrm{~kJ} / \mathrm{kg}$. The sensible heat of water 
vapor is the amount of heat required to raise the temperature of water vapor from $100^{\circ} \mathrm{C}$ to $800^{\circ} \mathrm{C}$ which is the furnace temperature, and the specific heat capacity of water vapor at $800^{\circ} \mathrm{C}$ is $1.996 \mathrm{~kJ} / \mathrm{kg} \mathrm{K}$. For calculating the total heat released, the heating value of the biomass is set at $20,000 \mathrm{~kJ} / \mathrm{kg}$ and the heat required to raise the temperature of the biomass sample from ambient temperature to the auto-ignition temperature of biomass which is $300^{\circ} \mathrm{C}$, is set at $687.5 \mathrm{~kJ} / \mathrm{kg}$. Therefore when the sample is dry, the net heat released is $19.31 \mathrm{~kJ}$ and for different values of moisture content, the total heat required for drying is subtracted from the total heat released from combustion.

Table 5. Effect of moisture content on net heat release from biomass combustion

\begin{tabular}{|c|c|c|c|c|c|c|c|}
\hline $\begin{array}{c}\text { Moisture } \\
\text { Content } \\
(\%)\end{array}$ & $\begin{array}{l}\text { Total } \\
\text { Weight } \\
\text { (g) }\end{array}$ & $\begin{array}{c}\text { Water } \\
(\mathrm{g})\end{array}$ & $\begin{array}{c}\text { Sensible } \\
\text { Heat of } \\
\text { Water }(\mathrm{kJ})\end{array}$ & $\begin{array}{c}\text { Latent Heat } \\
\text { of } \\
\text { Evaporation } \\
\text { (kJ) }\end{array}$ & $\begin{array}{c}\text { Sensible } \\
\text { Heat of } \\
\text { Water } \\
\text { Vapor (kJ) }\end{array}$ & $\begin{array}{c}\text { Total } \\
\text { Heat for } \\
\text { Drying } \\
\text { (kJ) }\end{array}$ & $\begin{array}{c}\text { Net Heat } \\
\text { Release } \\
(\mathbf{k J})\end{array}$ \\
\hline 0 & 1.00 & 0.00 & 0.00 & 0.00 & 0.00 & 0.00 & 19.31 \\
\hline 10 & 1.11 & 0.11 & 0.03 & 0.25 & 0.16 & 0.44 & 18.87 \\
\hline 20 & 1.25 & 0.25 & 0.08 & 0.57 & 0.35 & 1.00 & 18.32 \\
\hline 30 & 1.43 & 0.43 & 0.13 & 0.97 & 0.60 & 1.71 & 17.61 \\
\hline 40 & 1.67 & 0.67 & 0.21 & 1.51 & 0.93 & 2.65 & 16.66 \\
\hline 50 & 2.00 & 1.00 & 0.31 & 2.27 & 1.40 & 3.98 & 15.33 \\
\hline 60 & 2.50 & 1.50 & 0.47 & 3.41 & 2.10 & 5.97 & 13.34 \\
\hline 70 & 3.33 & 2.33 & 0.73 & 5.30 & 3.26 & 9.29 & 10.02 \\
\hline 80 & 5.00 & 4.00 & 1.26 & 9.08 & 5.59 & 15.93 & 3.39 \\
\hline 83 & 5.88 & 4.88 & 1.53 & 11.08 & 6.82 & 19.44 & -0.13 \\
\hline
\end{tabular}




\subsubsection{Data Analysis}

For each mill, the operation of their biomass boiler was reviewed over a two year period and the data for the pertinent operating parameters was collected as daily averages and the changes of different operating parameters with respect to one another were studied. The moisture content of the feedstock was not measured on a regular basis at all mills. Therefore, in order to be able to study the effect of moisture content on other operating parameters, an energy and material balance was constructed for each biomass boiler and the average daily moisture content was back calculated. Figure 35 shows a simplified box diagram of a biomass boiler and the different heat components $(\mathrm{Q})$ used in the energy balance.

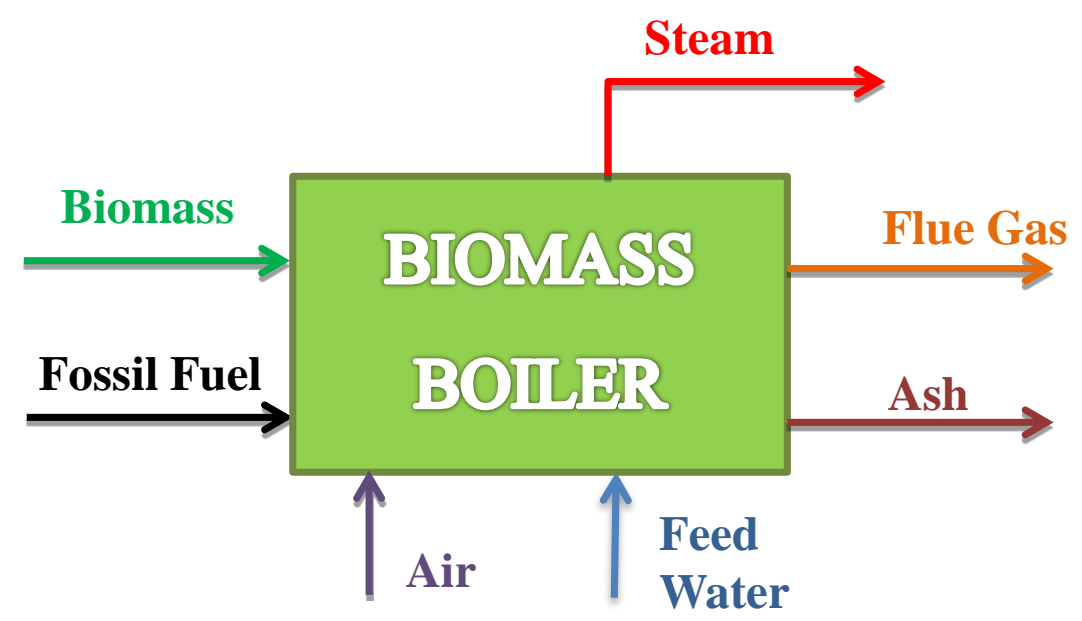

Figure 35. Biomass boiler box diagram

$$
\begin{gathered}
Q_{\text {in }}=Q_{\text {biomass }}+Q_{\text {fossil fuel }} \\
Q_{\text {loss }}=Q_{\text {flue gas }}+Q_{\text {air }}+Q_{M C}+Q_{\text {radiation }}+Q_{\text {ash }}+Q_{\text {unaccounted }} \\
Q_{\text {steam }}=Q_{\text {in }}-Q_{\text {loss }}
\end{gathered}
$$

Table 6 shows a summary of the input and output variables for one set of data, where the average daily values of the operating parameters are used to calculate the average moisture content of the feedstock for that particular day, the same calculations have been carried out using a macro 
based spreadsheet to calculate the average daily moisture content for two years of data. For the output variables, the measured and calculated values for the excess $\mathrm{O}_{2}$ of the stack are used to verify the accuracy of the calculations as shown in Appendix 4.

Table 6. Summary of input and output variables for one set of data for Mill A used to calculate moisture content

\begin{tabular}{|c|c|}
\hline \multicolumn{2}{|c|}{ Input Variables } \\
\hline Biomass Feed Rate & $25.9 \mathrm{~T} / \mathrm{h}$ \\
\hline Air Flow Rate & $207 \mathrm{~T} / \mathrm{h}$ \\
\hline Inlet Air Temperature & $18^{\circ} \mathrm{C}$ \\
\hline Natural Gas Flow Rate & $462 \mathrm{~m}^{3} / \mathrm{h}$ \\
\hline Fuel Oil Flow Rate & $2.0 \mathrm{~T} / \mathrm{h}$ \\
\hline Flue Gas Temperature & $200^{\circ} \mathrm{C}$ \\
\hline Steam Flow Rate & $92 \mathrm{~T} / \mathrm{h}$ \\
\hline Steam Temperature & $438^{\circ} \mathrm{C}$ \\
\hline Steam Pressure & $6205 \mathrm{kPa}$ \\
\hline Output Variables \\
\hline Moisture Content & $45 \%$ \\
\hline Excess $\mathbf{O}_{2}$ (calculated) & $7.7 \%$ \\
\hline Excess $\mathbf{O}_{2}$ (measured) & $8.1 \%$ \\
\hline
\end{tabular}


The main objective of this was to find which parameters could be used to detect variations in moisture content and which parameters could be used to minimize the fluctuation in the operation due to the variations in moisture content before the need to co-combust fossil fuels. After calculating moisture content for each set of data, all the operating parameters were compared to the calculated value of the moisture content to find which parameter is impacted by changes in moisture content. The changes of all the operating parameters with moisture content are listed in Appendix 4. Of all the operating parameters, it was found that lower furnace temperature, excess $\mathrm{O}_{2}$ and undergrate air have the most direct relationship with moisture content.

Figures 36, 37 and 38 show the main findings from data analysis. Lower furnace temperature, excess $\mathrm{O}_{2}$ and undergrate air are plotted respectively on the left hand axis with moisture content on the right hand axis to show the relationship between each operating parameter and moisture content. For comparison purposes, moving averages of each value is plotted in the figures.

The results suggest that moisture content and furnace temperature have an inverse relationship and excess $\mathrm{O}_{2}$ and undergrate air have a direct relationship with moisture content. 


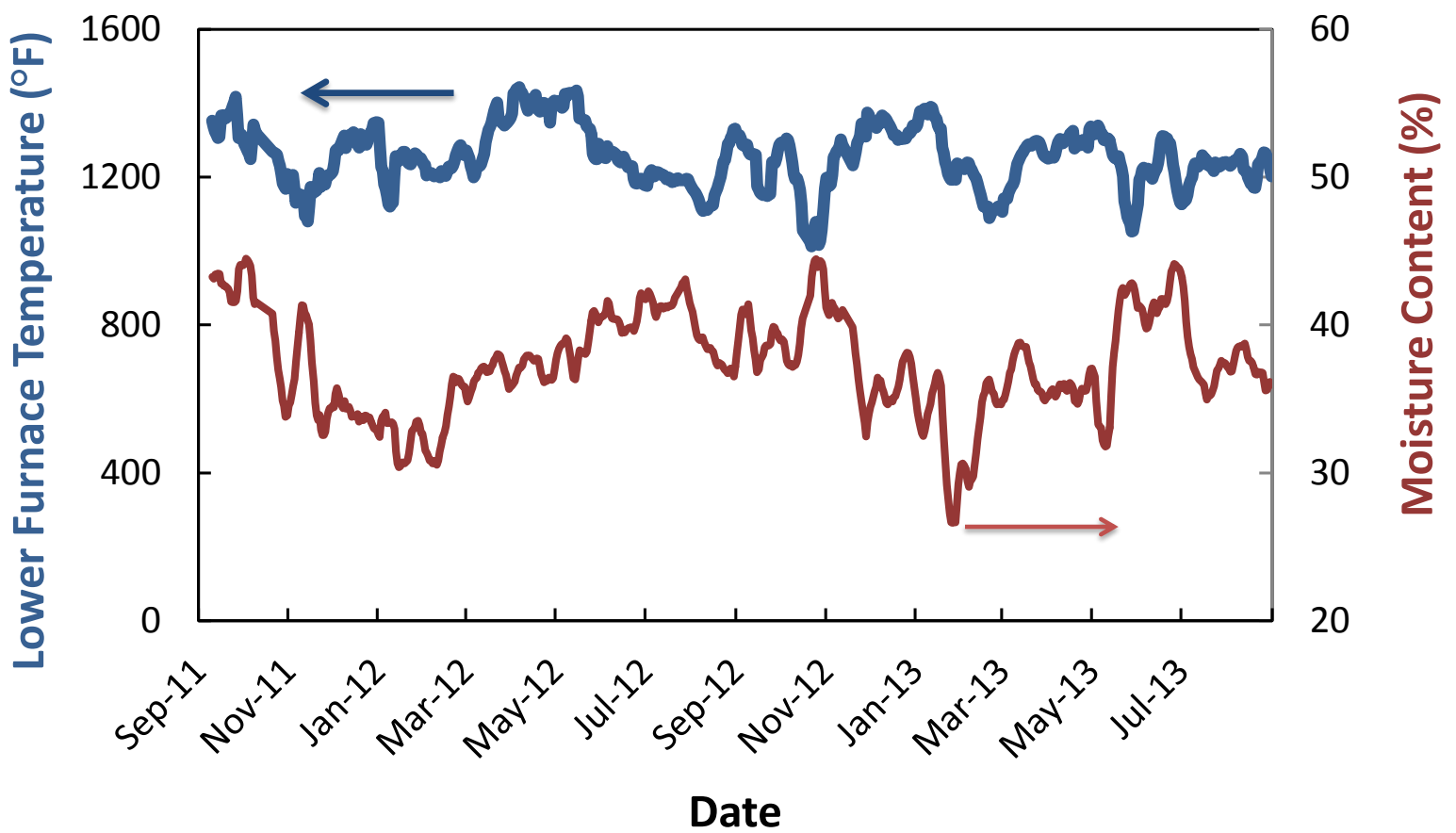

Figure 36. Changes of furnace temperature and moisture content with time

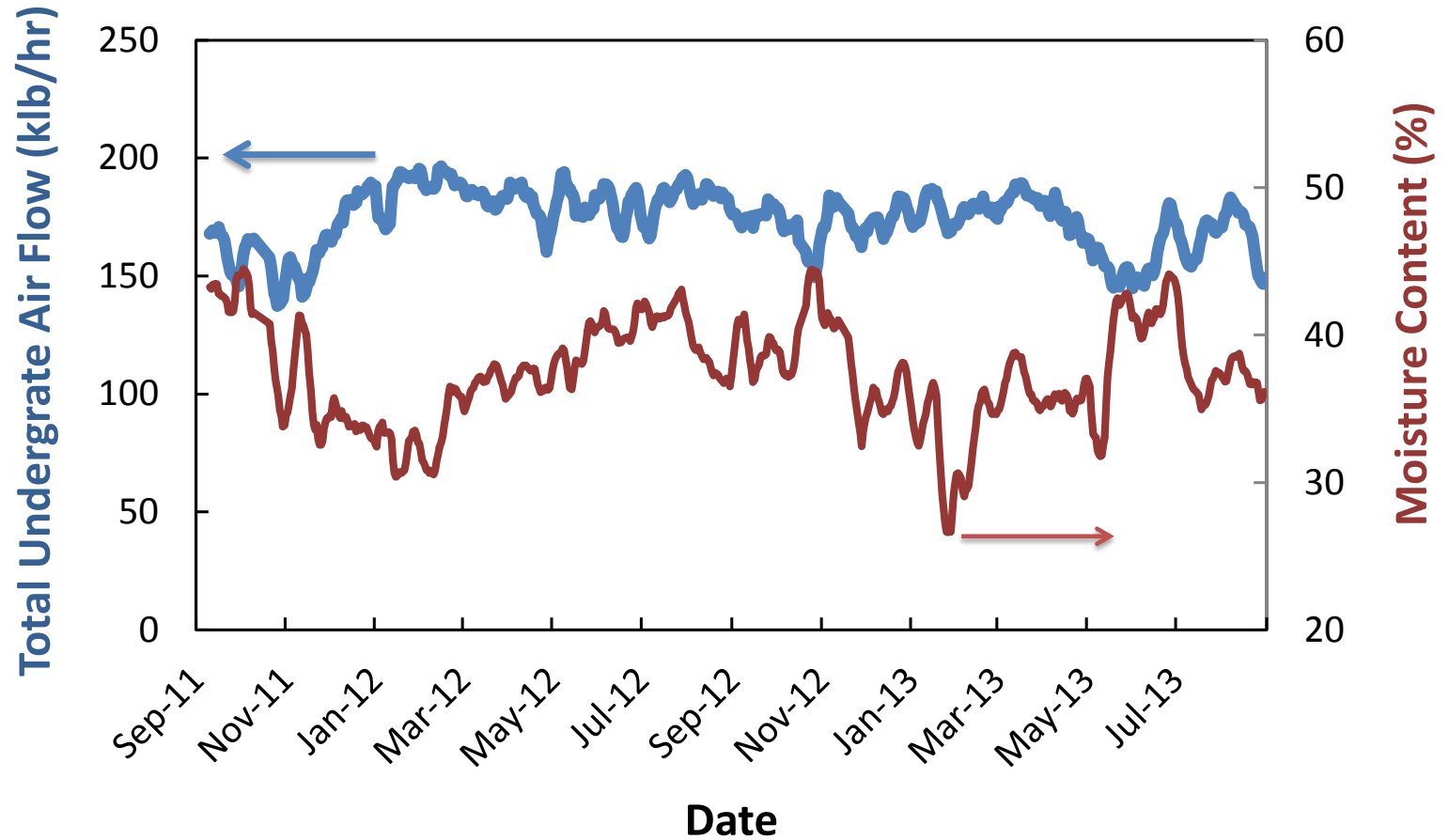

Figure 37. Changes of undergrate air flow rate and moisture content with time 


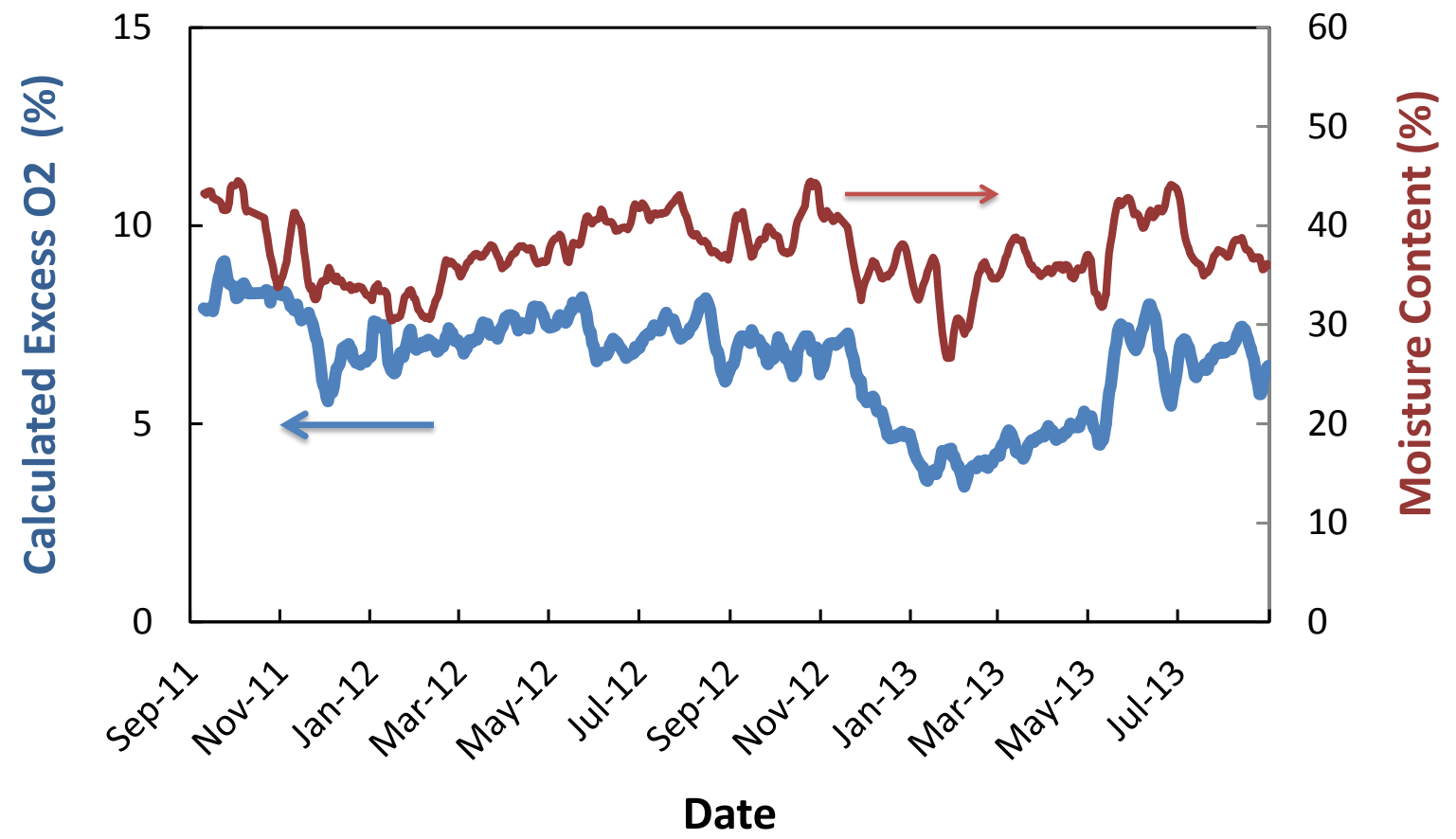

\section{Figure 38. Changes of excess $\mathrm{O}_{2}$ and moisture content with time}

The changes in the lower furnace temperature or the stack temperature with moisture content variations can be explained as follows: when the moisture content of the feedstock increases, more heat is required to dry the biomass in order for devolatilization to start, for this reason the net heat release from combustion decreases resulting in the lower furnace temperature to decrease and eventually the stack flue temperature decreases as well.

The undergrate air is changed by the operator in order to maintain a set amount of pressure in the steam header. The data analysis results suggest that the undergrate air is used as a control parameter for high moisture content: the operator increases the undergrate air when high moisture content is suspected in order to speed up the drying process. The increase in excess $\mathrm{O}_{2}$ with moisture content on the other hand, can be due to this increase of undergrate air or due to the overall increase in flue gas amount with increasing moisture content. 
After considering all the operating parameters collected for each biomass boiler, it was concluded that furnace temperature or stack temperature and excess $\mathrm{O}_{2}$ can be used to indicate variations in moisture content. Undergrate air can be the control parameter for maintaining a constant steam flow when changes in moisture content are detected. Also the material and energy balance can be used as a tool for measuring the moisture content of the feedstock at any given time.

\subsubsection{Thermal Performance}

The average values for the operating parameters which were used for the purposes of data analysis are shown in Table 7. The auxiliary fuels burnt in all three boilers are natural gas and only Mill A burns fuel oil as well. Therefore the average natural gas flow rate is lower for mill A since two types of auxiliary fuels are burnt to compensate for steam production. 
Table 7. Average values for operating parameters of mills A, B, and C

\begin{tabular}{|c|c|c|c|}
\hline Average Operating Parameters & Mill A & Mill B & Mill C \\
\hline Biomass Feed Rate (T/h) & 26.3 & 26.8 & 56.0 \\
\hline Air Flow Rate (T/h) & 209 & 139 & 266 \\
\hline Undergrate Air Flow Rate (T/h) & 80.3 & 77.1 & 72.2 \\
\hline Inlet Air Temperature $\left({ }^{\circ} \mathrm{C}\right)$ & 89 & 145 & 176 \\
\hline Natural Gas Flow Rate $\left(\mathrm{m}^{3} / \mathrm{h}\right)$ & 843 & 3504 & 3501 \\
\hline Fuel Oil Flow Rate (T/h) & 1.0 & - & - \\
\hline Flue Gas Temperature $\left({ }^{\circ} \mathrm{C}\right)$ & 214 & 171 & 179 \\
\hline Steam Flow Rate (T/h) & 97 & 120 & 129 \\
\hline Steam Temperature $\left({ }^{\circ} \mathrm{C}\right)$ & 438 & 442 & 392 \\
\hline Steam Pressure (kPa) & 6205 & 6310 & 4494 \\
\hline Moisture Content (\%) & 38 & 40 & 58 \\
\hline Excess $\mathrm{O}_{2}(\%)$ & 7.7 & 5.5 & 7.3 \\
\hline
\end{tabular}

For each biomass boiler studied, thermal performance was compared to theoretical values which were calculated from the material and energy balance as discussed previously. The results are shown in Figure 39 where the thermal performance is defined as follows:

$$
\text { Thermal Performance }=\frac{\text { Steam produced from biomass }}{\text { Amount of dry biomass }}
$$




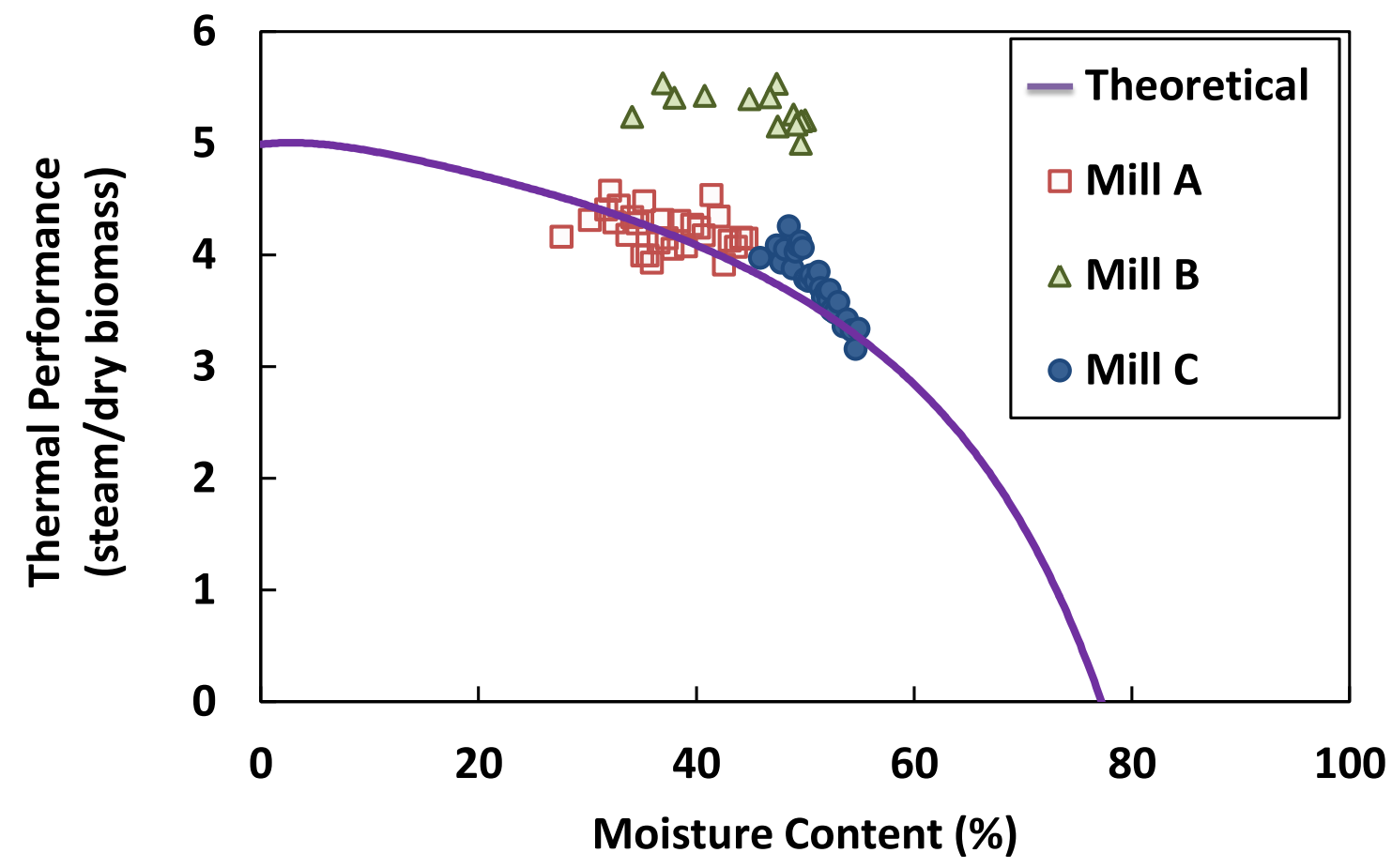

Figure 39. Thermal performance of mills A, B and C

The results show that the thermal performance of mill $\mathrm{A}$ is very close to theoretical values for a range of moisture contents from $30 \%$ to $50 \%$. This is an indication that mill A does not operate with very high moisture contents at the expense of co-combusting fossil fuels. Rather it seems that the different piles of biomass are mixed before entering the boiler in order to achieve moderate moisture contents and relatively constant steam production. Similarly, the thermal performance of Mill C is very close to theoretical values for moisture contents ranging from $40 \%$ to $60 \%$. Again this is an indication that for higher moisture contents, either the biomass feed is shut off completely and only fossil fuels combusted in the boiler, or that the moisture content of the entering feedstock is controlled and monitored to stay well below $60 \%$. On the other hand, the results from Mill B show much higher thermal performance values even for high moisture contents. This could be due to many factors, for example it is not clear whether the amount of steam used in soot blowing of the tube banks in the super heater area is included in the total steam measurements or not. Another significant issue in the calculations is the assumed heating value of the feedstock. As discussed previously, the feedstock of biomass boilers in pulp and paper mills can come from many different sources and are often the rejects or wastes produced in 
other parts of the process. This makes a constantly varying, non-homogenous mixture for the feedstock. For this reason, it is almost impossible to classify the different types of wood species entering the boiler at any given time as it is made from different mixtures. Considering this issue for calculation purposes, it can be seen that the moisture and ash content, and therefore the heating value, of the feedstock is unknown and an average or typical value is considered for calculation purposes. This can be the source of the discrepancies observed between the thermal performance of the biomass boilers and theoretical values calculated from energy and material balances. 


\section{Chapter 6 \\ Conclusions and Recommendations}

\section{Conclusions and Recommendations}

\subsection{Conclusions}

A two part fundamental study was performed to systematically investigate the effect of moisture content on the combustion behaviour of several wood species, first using a thermogravimetric combustor controlled at different temperatures, and second by conducting field studies and data analysis. The results show that:

- Combustion occurs through three stages: time-to-ignition (mostly drying), volatile burning, and char burning;

- Drying occurs more readily on the transverse surface of the biomass sample than on tangential and radial surfaces;

- Increasing the moisture content of the sample significantly increases the drying time and hence, the time-to-ignition. It has only a small effect on the volatile burning time and virtually no effect on the char burning time;

- Furnace temperature has a significant effect on combustion. Samples containing 40\% moisture can ignite and burn readily at $800^{\circ} \mathrm{C}$, but take a much longer time to ignite and to burn at $500^{\circ} \mathrm{C}$, and do not ignite at all at $400^{\circ} \mathrm{C}$;

- Of the wood species tested, softwood, due to its lower density (higher porosity), dries faster, catches fire sooner, and burns more readily than hardwood.

- Effects of moisture content and furnace temperature on jack pine bark combustion are similar to those of jack pine wood. The main difference is that bark burns at a slightly higher volatile burning rate and tends to produce fire sparks during combustion. 
- The results from field studies and data analysis suggest that the combination of excess $\mathrm{O}_{2}$ and furnace temperature could be used as detection parameters for changes in moisture content and change in undergrate air can be the first control strategy to deal with variations in moisture content before co-combusting fossil fuels.

- The thermal performance of three boilers indicated that the average moisture content of the feedstock is $30 \%$ to $60 \%$. For mills $\mathrm{A}$ and $\mathrm{B}$, the thermal performance is close to theoretical values, whereas the thermal performance of mill $\mathrm{C}$ was higher than theoretical values, nevertheless the rate of decrease in thermal performance with increase in moisture content was similar for the three boilers studied.

- The combined adverse effect of high moisture content in feedstock and low furnace temperature on combustion will eventually lead to a boiler blackout, unless the biomass feed rate is significantly reduced, a drier feedstock is used, and/or the auxiliary fuel (natural gas and fuel oil) flow rate is increased to maintain the furnace temperature. Also, it will likely result in increased combustibles and volatile organic compound (VOC) concentrations in the biomass boiler flue gas.

\subsection{Recommendations}

For the continuation of this work, the following issues can be considered:

- The thermogravimetric combustor is a batch like process where continuous feed is not possible; therefore it would be beneficial if moisture content experiments are carried out in a continuous way in order to monitor the changes in temperature and composition of flue gases during combustion.

- The combination of optimum moisture content and size need to be considered.

- Trial runs could give insight to how moisture content affects the actual operation of a boiler and which parameters are affected most.

- The energy balance used here could be tailored to each individual boiler for real time moisture content measurement. 


\section{References}

[1] Brewster, J., "Energy Optimization," TAPPI Kraft Recovery Operation Course, St. Petersburg, FL., (2009).

[2] Demirbas, A., "Potential applications of renewable energy sources, biomass combustion problems in boiler power systems and combustion related environmental issues," Progress in Energy and Combustion Science, vol. 31, pp. 171-192, (2005).

[3] Gavrilescu, D. ,"Energy From Biomass in Pulp and Paper Mills," Environmental Engineering and Management Journal, pp. 537-546, (2008).

[4] Basu, P. , Biomass Gasification and Pyrolysis: Practical Design and Theory, Oxford: Academic Press, (2010).

[5] Nussbaumer, T., "Combustion and Co-combustion of Biomass: Fundamentals, Technologies, and Primary Measures for Emission Reduction," Energy and Fuels, pp. 15101521, (2003).

[6] Jenkins, B., Baxter, L., Miles,T. , Jr., and Miles, T. , "Combustion Properties of Biomass," Fuel Processing Technology, pp. 17-46, (1998).

[7] Khan, A., de Jon, W. , Jansens, P. , and Spliethoff, H. , "Biomass Combustion in Fluidized Bed Boilers: Potential Problems and Remedies," Fuel Processing Technology, pp. 21$50,(2009)$.

[8] Shanmukharadhya , K., and Sudhakar, K.,"Effect of Fuel Moisture on Combustion in a Bagasse Fired Furnace," Journal of Energy Resources Technology, vol. 129, no. 3, pp. 248-253,( 2007).

[9] Suksankraisorn, K. , Patumsawad ,S. ,and Fungtammasan, B. , "Combustion studies of high moisture content waste in a fluidised bed," Waste Management , pp. 433-439, (2003).

[10] Blasi , C. , "Modeling chemical and physical processes of wood and biomass pyrolysis," Progress in Energy and Combustion Science, vol. 34, no. 1, pp. 47-90, (2008). 
[11] Li, H., Chen, Q., Zhang, X. , Finney, K. N.,. Sharifi, V. N, and Swithenbank, J., "Evaluation of a Biomass Drying Process Using Waste Heat From Process Industries," Applied Thermal Engineering, pp. 71-80,( 2012).

[12] Yang, Y., Sharifi, V., Swithenbank, J. , Ma, L., Darvell, L., Jones, J., Pourkashanian, M. and Williams, A., "Combustion of a Single Particle of Biomass," Energy and Fuels, pp. 306-316, (2008).

[13] Saito, M., Amagai, K., Ogiwara, G. , and Arai, M., "Combustion characteristics of waste material containing high moisture," Fuel, pp. 1201-1209, (2001).

[14] Deigo, L. F., Garcia-Laiano, F., Abad, A., Gayan , P. , and Adanez, J., "Modeling of the devolatilization of nonspherical wet pine wood particles in fluidized beds," Industrial and Engineering Chemistry Research, vol. 41, no. 15, pp. 3642-3650, (2002).

[15] Shin, D. , Jang, S. , and Hwang , J., "Combustion characteristics of paper mill sludge in a lab-scale combustor with internally cycloned circulating fluidized bed," Waste Management , vol. 25, pp. 680-685, (2005).

[16] Ogada, T., and Werther, J., "Combustion characteristics of wet sludge in a fluidized bed," Fuel , vol.75, pp. 617-626,(1996).

[17] Shin, D., and. Choi, S., "The Combustion of Simulated Waste Particles in a Fixed Bed," Combustion and Flame, vol.121, pp. 167-180,( 2000).

[18] Yang, Y. , Ryu, C., Goodfellow, J., Nasserzadeh Sharifi, V., and Swithenbank, J., "Modelling waste combustion in grate furnaces," Process Safety and Environmental Protection, vol.82, pp. 208-222,( 2004).

[19] Yang, Y. B. , Ryu, C., Khor, A., Sharifi , V. N., and Swithenbank, J., "Fuel size effect on pinewood combustion in a packed bed," Fuel , vol. 84, pp. 2026-2038, (2005).

[20] Bruch, C., Peters, B.,and Nussbaumer, T., "Modelling wood combustion under fixed bed conditions," Fuel, vol. 82, pp. 729-738, (2003). 
[21] McDermott, R. , Morris, K. , and Sanderson, J. , "A better boiler for wet hog fuel," in Technical Section, Canadian Pulp and Paper Association, Montreal, 1981.

[22] Linderoth, C. E., "Why dry hog fuel?," in Technical Section, Canadian Pulp and Paper Association, Montreal, (1985).

[23] Khothsombath, B., [Online]. Available:

http://blog.lib.umn.edu/khoth002/architecture/2006/10/phenomena_1.html. [Accessed July $2014]$.

[24] Wiedenhoeft, A. C., and Miller, R. B., "Structure and Function of Wood," in Handbook of Wood Chemistry and Wood Composites, CRC Press, (2005), pp. 9-33.

[25] Sjostrom, E., Wood Chemistry: Fundamentals and Applications, Academic Press, (1993).

[26] Demirbas, A., "Combustion characteristics of different biomass fuels," Progress in Energy and Combustion Science, vol.30, pp. 219-230, (2004).

[27] Bridgwater, A., "The technical and economic feasibility of biomass gasification for power generation," Fuel, vol.74, pp. 631-653, (1995).

[28] Nystrom , J. , and Dahlquist, E., "Methods for determination of moisture content in woodchips for power plants- a review," Fuel, vol.83, pp. 773-779,( 2004).

[29] Yang, Y.,Yamauchi, H., Nasserzadeh ,V., and Swithenbank, J., "Effect of fuel devolatilization on the combustion of wood chips and incineration of simulated municipal solid wasted in a packed bed," Fuel, vol. 83, no. 11-12, pp. 2205-2221, (2003).

[30] Vamvuka, D., and Sfakiotakis, S., "Combustion behavior of biomass fuels and their blends with lignite," Thermochimica Acta, vol. 526, no. 1-2, pp. 192-199,( 2011). 
[31] Cherubini, F.,"The bio refinery concept: Using biomass instead of oil for producing energy and chemicals," Energy Conversion and Management, vol. 51, no. 7, pp. 1412$1421,(2010)$.

[32] Yin, C., Rosendahl, L., and Kaer, S., "Grate-firing of biomass for heat and power production," Progress in Energy and Combustion Science, vol. 34, no. 6, pp. 725-754, (2008).

[33] Richard, J., and Saastamoinen, J., "Simultaneous Drying and Pyrolysis of Solid Fuel Particles," Combustion and Flame, pp. 288-300, (1996).

[34] Lehtikangas, P., "Quality properties of pelletised sawdust, loggin residues and bark," Biomass and Bioenergy, pp. 351-360,(2001).

[35] Kurkela, E., "Formation and removal of biomass-derived contaminants in fluidized-bed gasficiation processes," VTT Publications, vol. 287, p. 47, (1996).

[36] Feldmann, H., Paisley, M., Appelbaum, H., and Taylor, D., "Conversion of forest residues to a methane-rich gas in a high-throughput gasifier," DE88013138, p. 108, (1988). 


\section{Appendices}

\section{Appendix 1. Effect of shape}

Table A- 1. Physical properties of pine samples

\begin{tabular}{|c|c|c|c|c|}
\hline Shape & Length $(\mathrm{cm})$ & Width $(\mathrm{cm})$ & Height $(\mathrm{cm})$ & Surface Area (cm2) \\
\hline & 1.4 & 1.3 & 1.2 & 10.6 \\
\hline & 2.1 & 1.2 & 1.0 & 11.6 \\
\hline & 3.0 & 0.9 & 0.9 & 12.2 \\
\hline
\end{tabular}

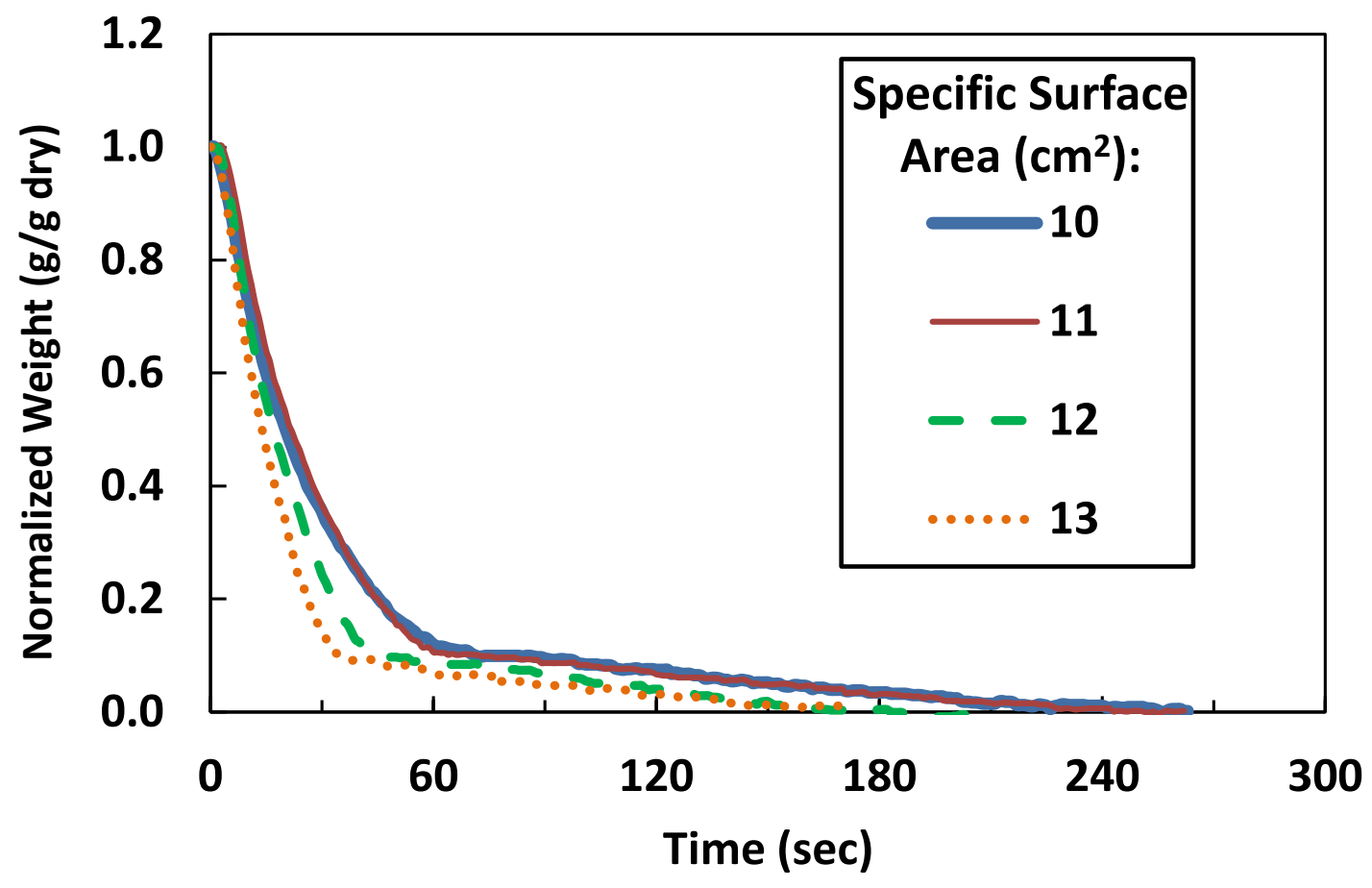

Figure A- 1. Weight change profile for combustion of pine at $800^{\circ} \mathrm{C}$ 


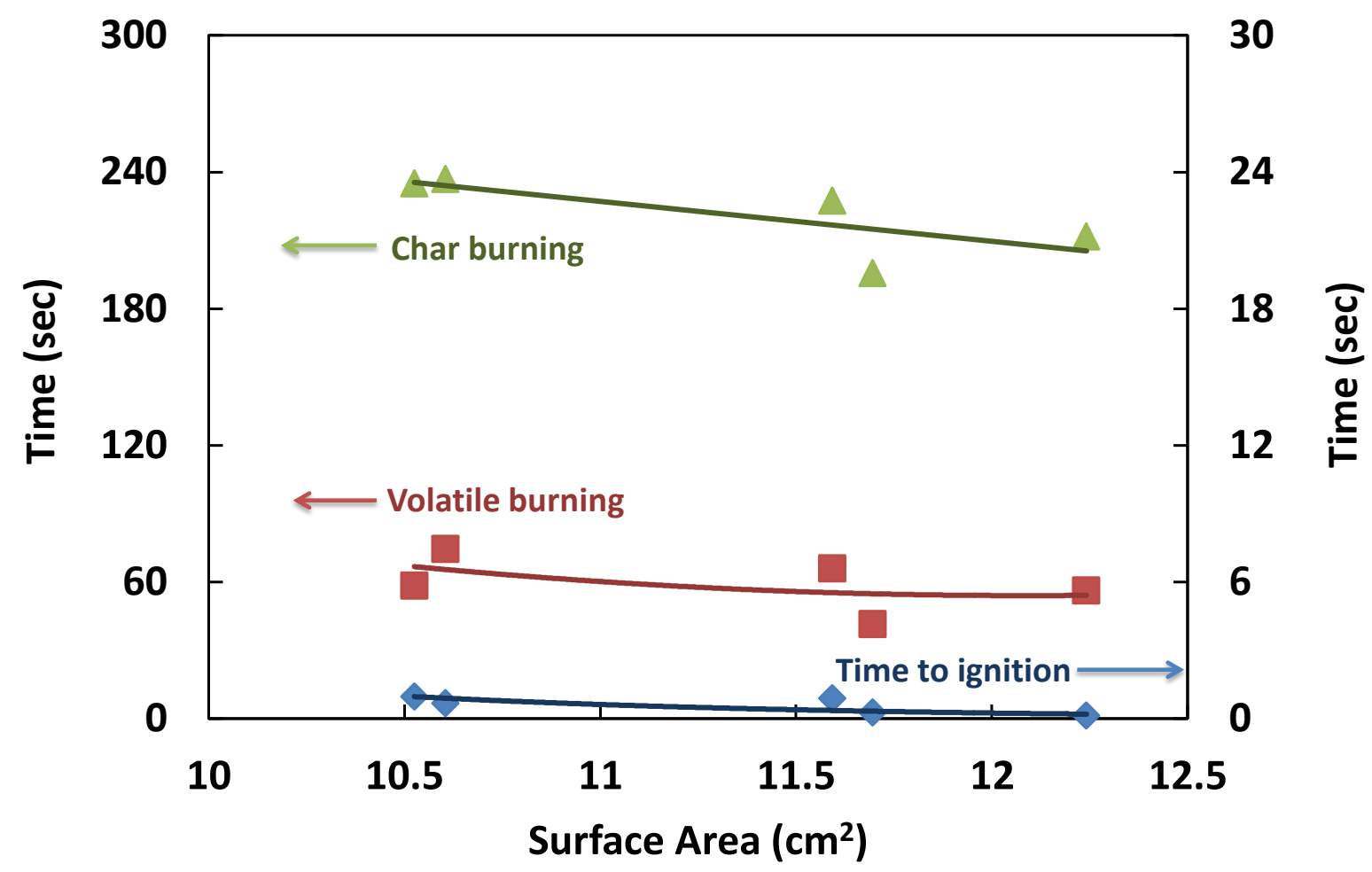

Figure A- 2. Combustion stages for pine at $800^{\circ} \mathrm{C}$

Table A- 2. Physical properties of oak samples

\begin{tabular}{|c|c|c|c|c|}
\hline Shape & Length (cm) & Width $(\mathrm{cm})$ & Height (cm) & Surface Area (cm2) \\
\hline & 1.4 & 1.3 & 1.2 & 10.6 \\
\hline & 1.9 & 1.2 & 1.1 & 11.5 \\
\hline & 3.0 & 1.0 & 0.8 & 12.0 \\
\hline
\end{tabular}




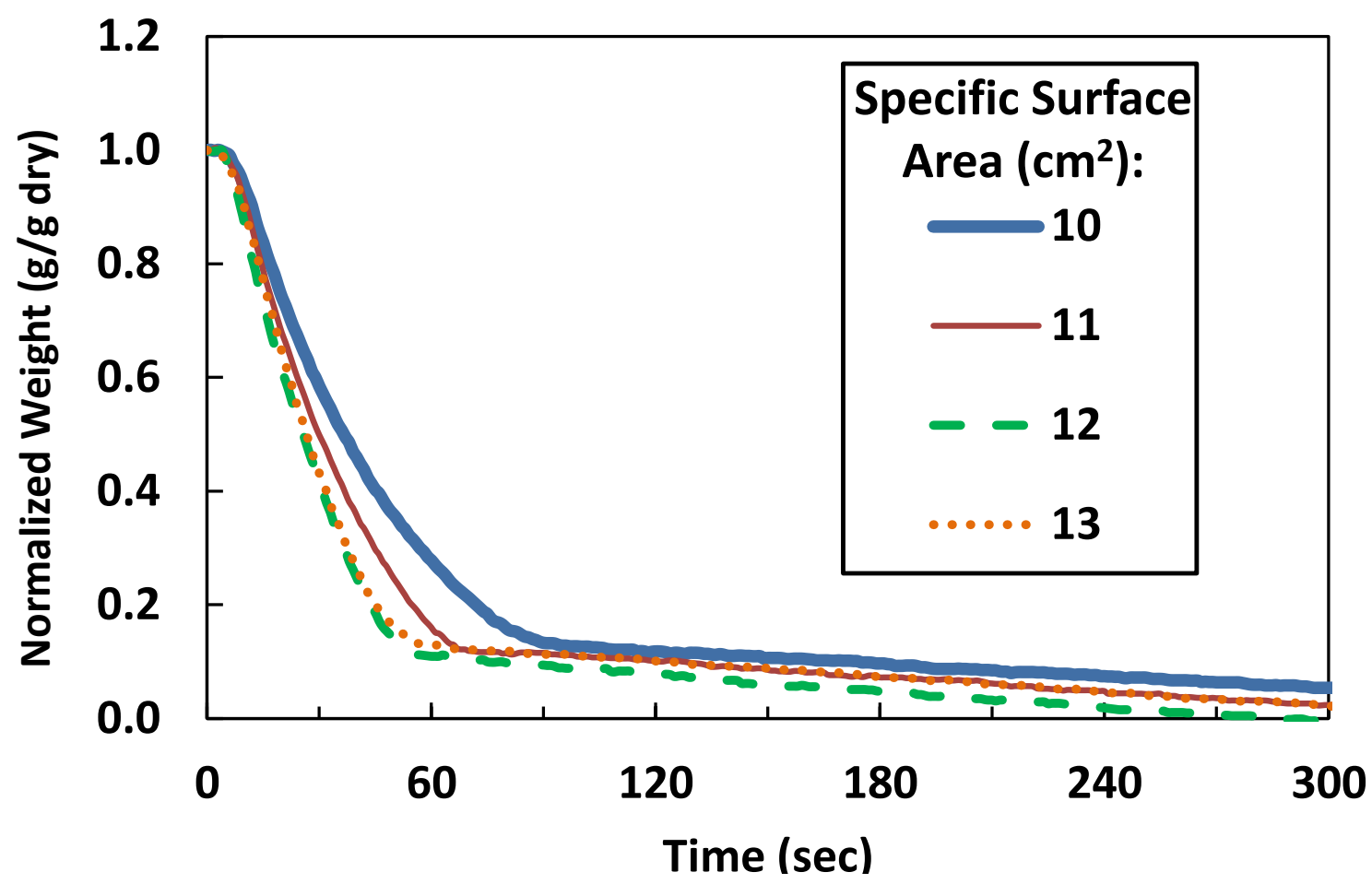

Figure A- 3. Weight change profile for combustion of oak at $800^{\circ} \mathrm{C}$

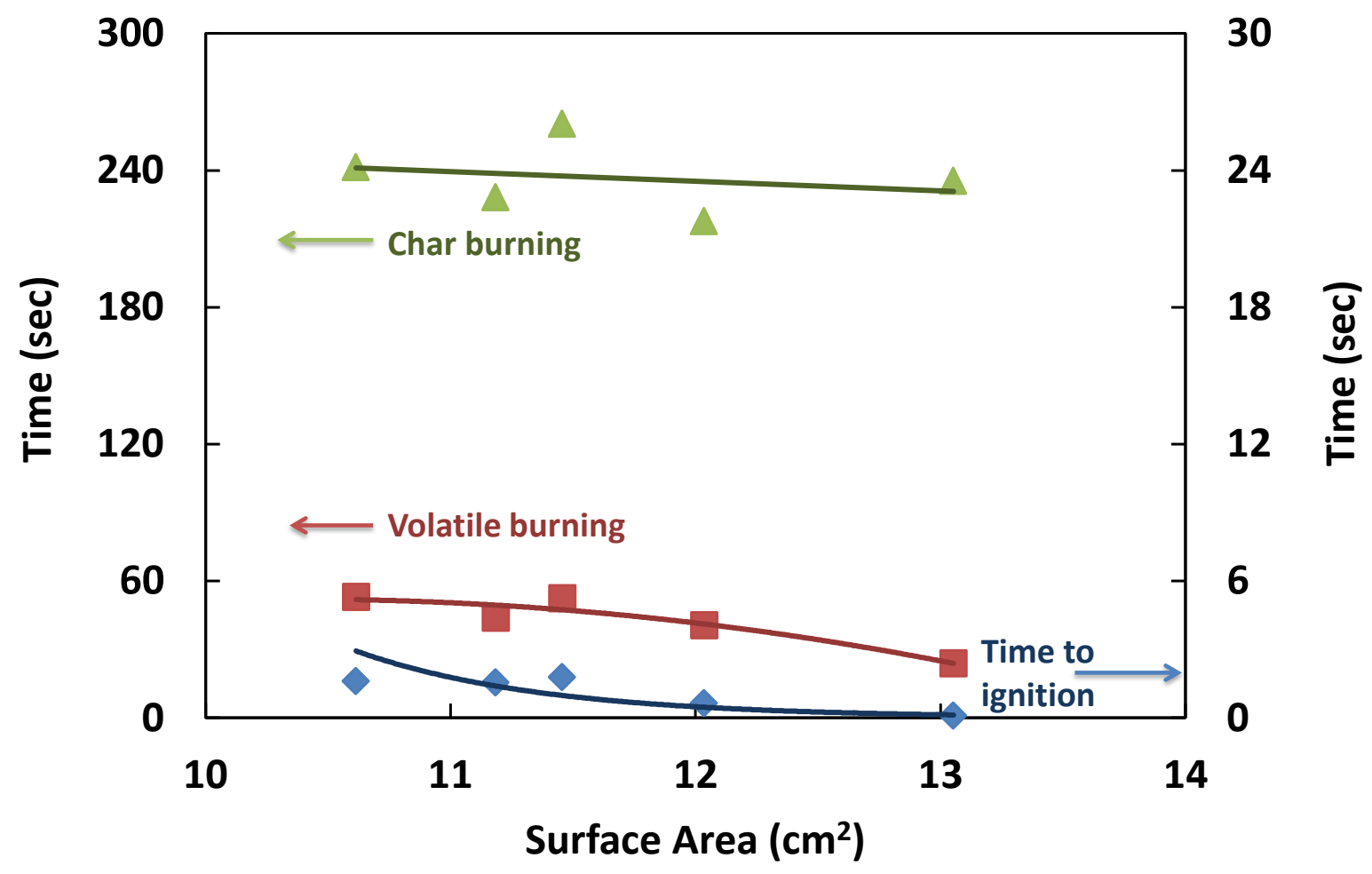

Figure A- 4. Combustion stages for oak at $800^{\circ} \mathrm{C}$ 


\section{Appendix 2. Effect of moisture content and wood species}

Wood Species: Cedar

Dry Weight: $0.82 \mathrm{~g}$
Furnace Temperature: $800^{\circ} \mathrm{C}$

Sample Size: $1.5 \mathrm{~cm} \times 1.2 \mathrm{~cm} \times 1.2 \mathrm{~cm}$

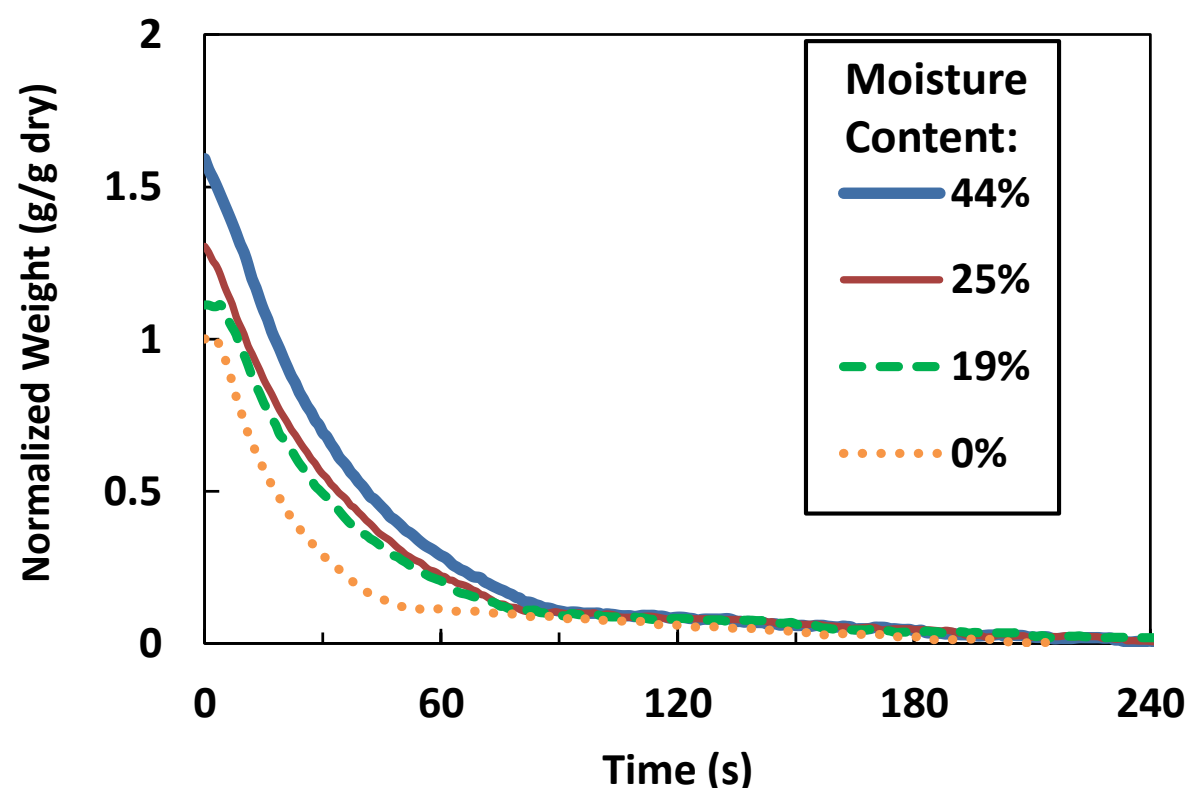

Figure A- 5. Weight change profile for combustion of cedar at $800^{\circ} \mathrm{C}(0.82 \mathrm{~g}$ dry weight $)$

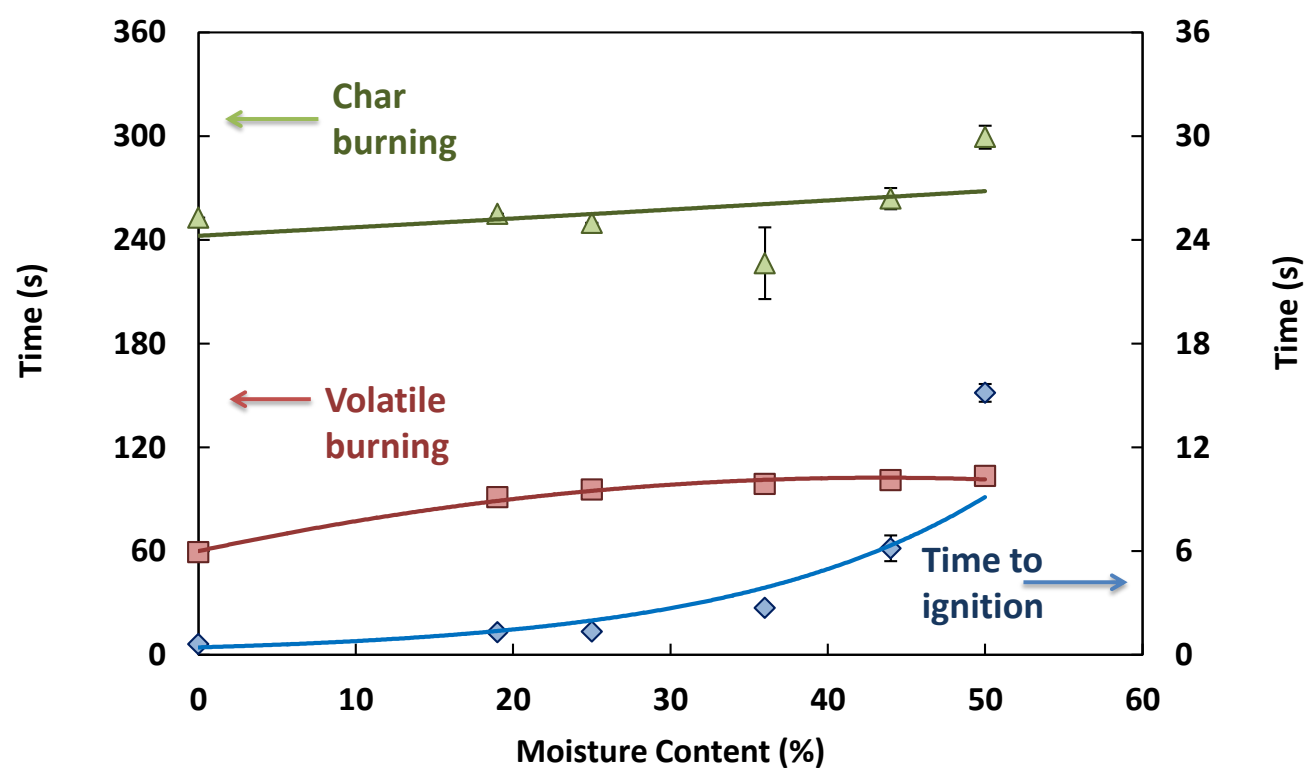

Figure A- 6. Combustion stages for cedar at $800^{\circ} \mathrm{C}(0.82 \mathrm{~g}$ dry weight $)$ 
Wood Species: Poplar

Dry Weight: $1.21 \mathrm{~g}$
Furnace Temperature: $800^{\circ} \mathrm{C}$

Sample Size: $1.5 \mathrm{~cm} \times 1.2 \mathrm{~cm} \times 1.2 \mathrm{~cm}$

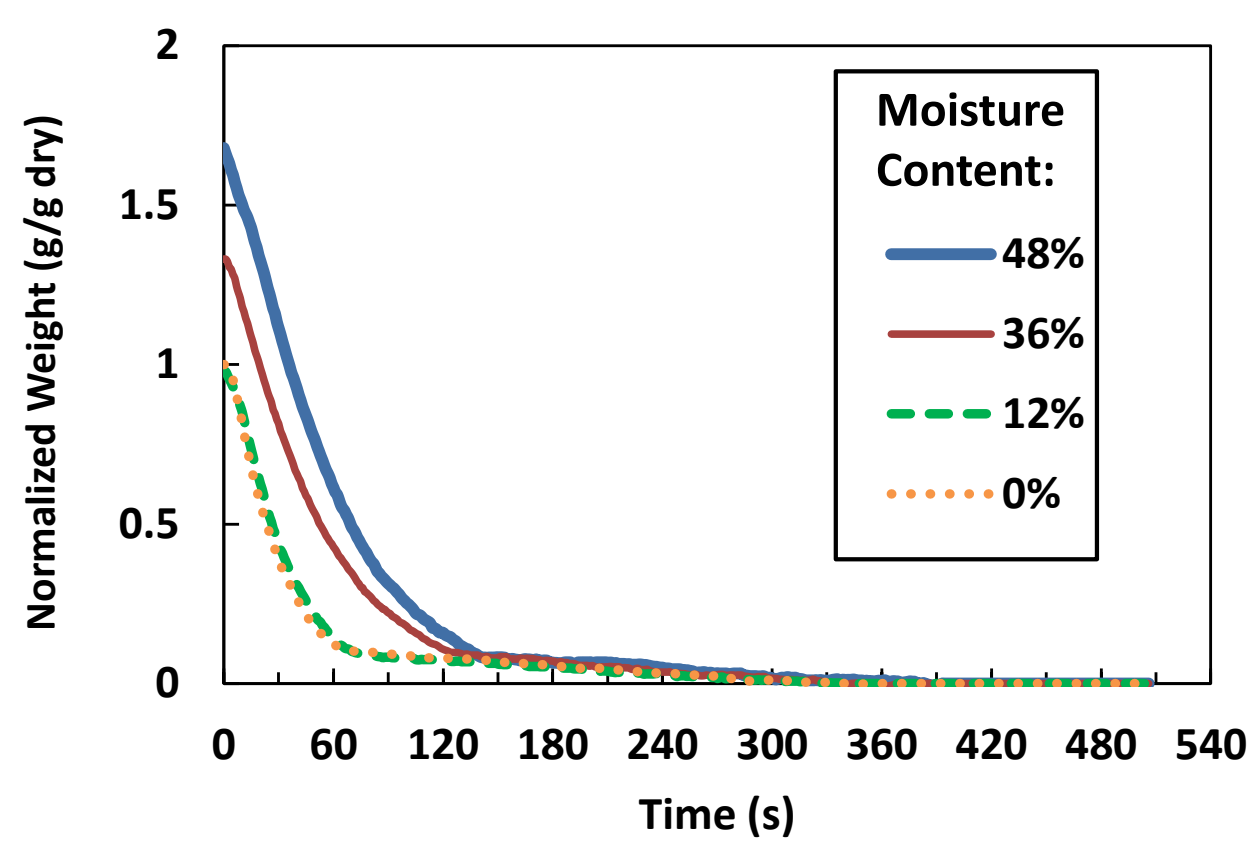

Figure A- 7. Weight change profile for combustion of poplar at $800^{\circ} \mathrm{C}(1.21 \mathrm{~g}$ dry weight $)$

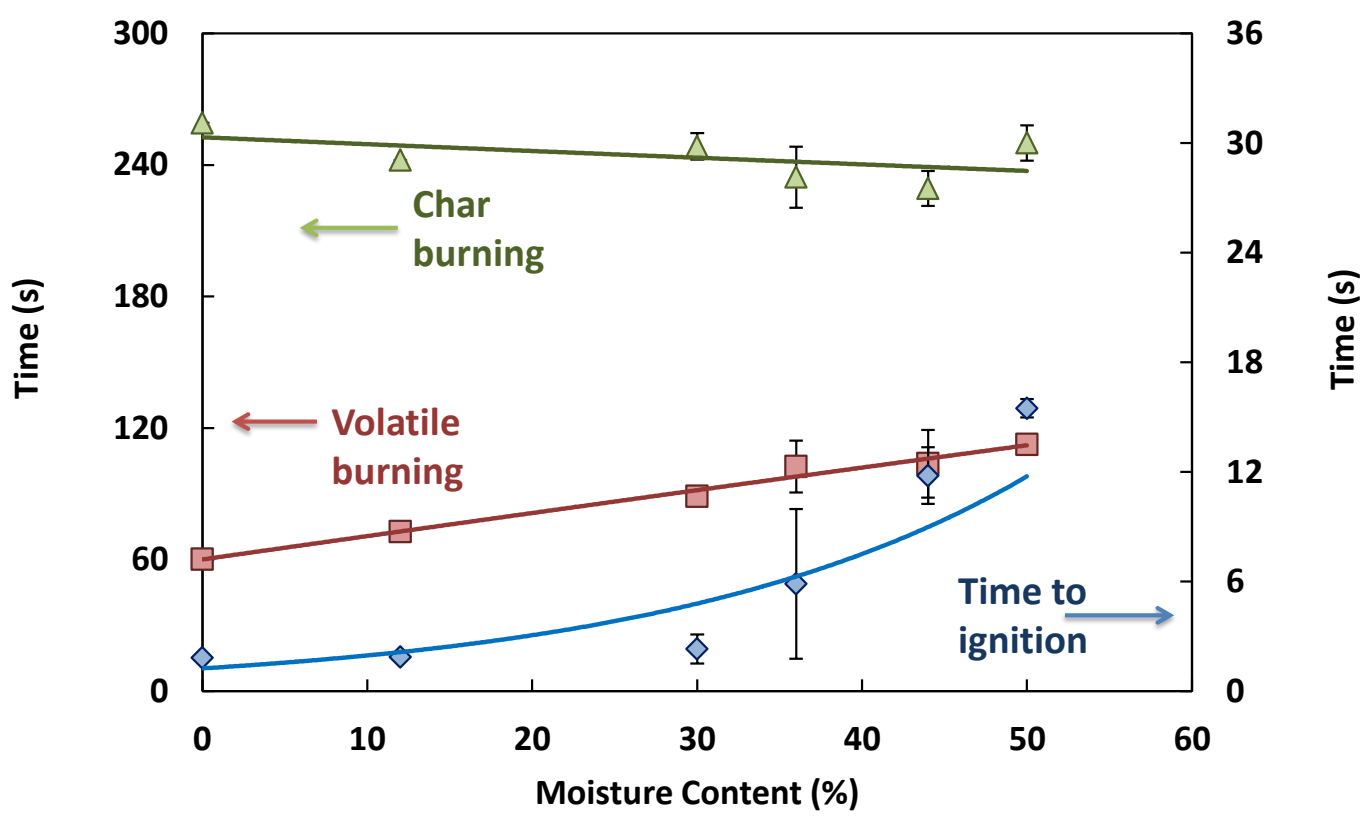

Figure A- 8. Combustion stages for poplar at $800^{\circ} \mathrm{C}(1.21 \mathrm{~g}$ dry weight $)$ 
Wood Species: Oak

Dry Weight: $1.34 \mathrm{~g}$
Furnace Temperature: $800^{\circ} \mathrm{C}$

Sample Size: $1.5 \mathrm{~cm} \times 1.2 \mathrm{~cm} \times 1.2 \mathrm{~cm}$

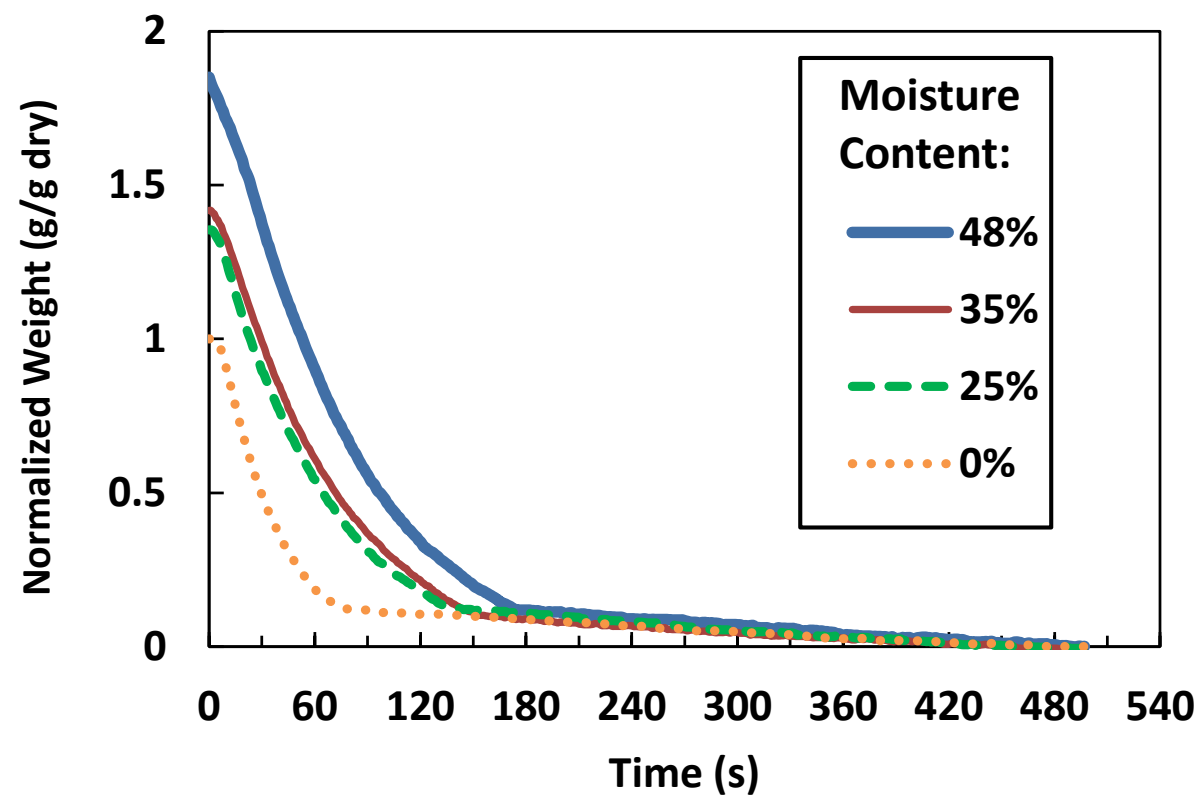

Figure A- 9. Weight change profile for combustion of oak at $800^{\circ} \mathrm{C}(1.34 \mathrm{~g}$ dry weight $)$

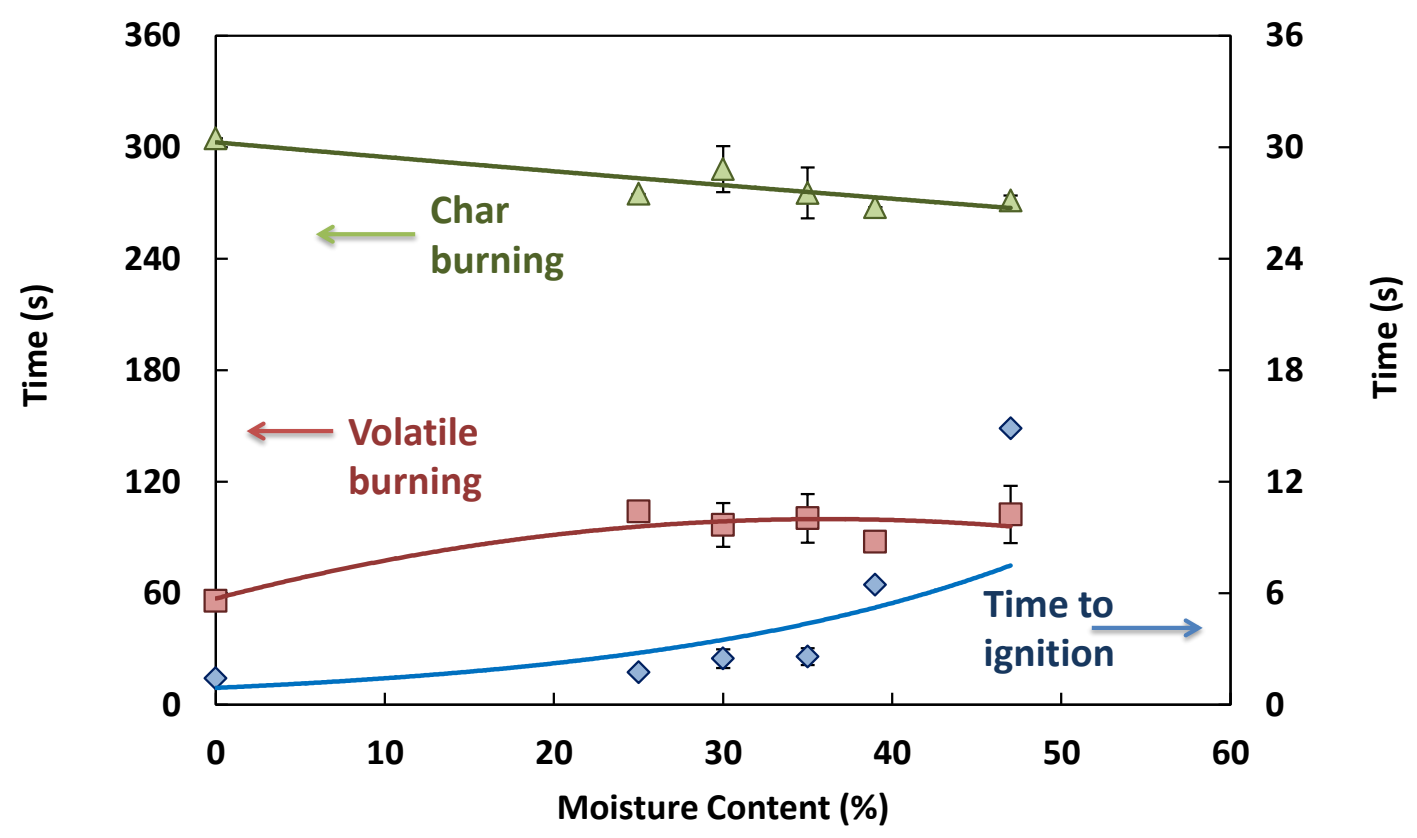

Figure A- 10. Combustion stages for oak at $800^{\circ} \mathrm{C}(1.34 \mathrm{~g}$ dry weight $)$ 
Wood Species: Maple

Dry Weight: $1.75 \mathrm{~g}$
Furnace Temperature: $800^{\circ} \mathrm{C}$

Sample Size: $1.5 \mathrm{~cm} \times 1.2 \mathrm{~cm} \times 1.2 \mathrm{~cm}$

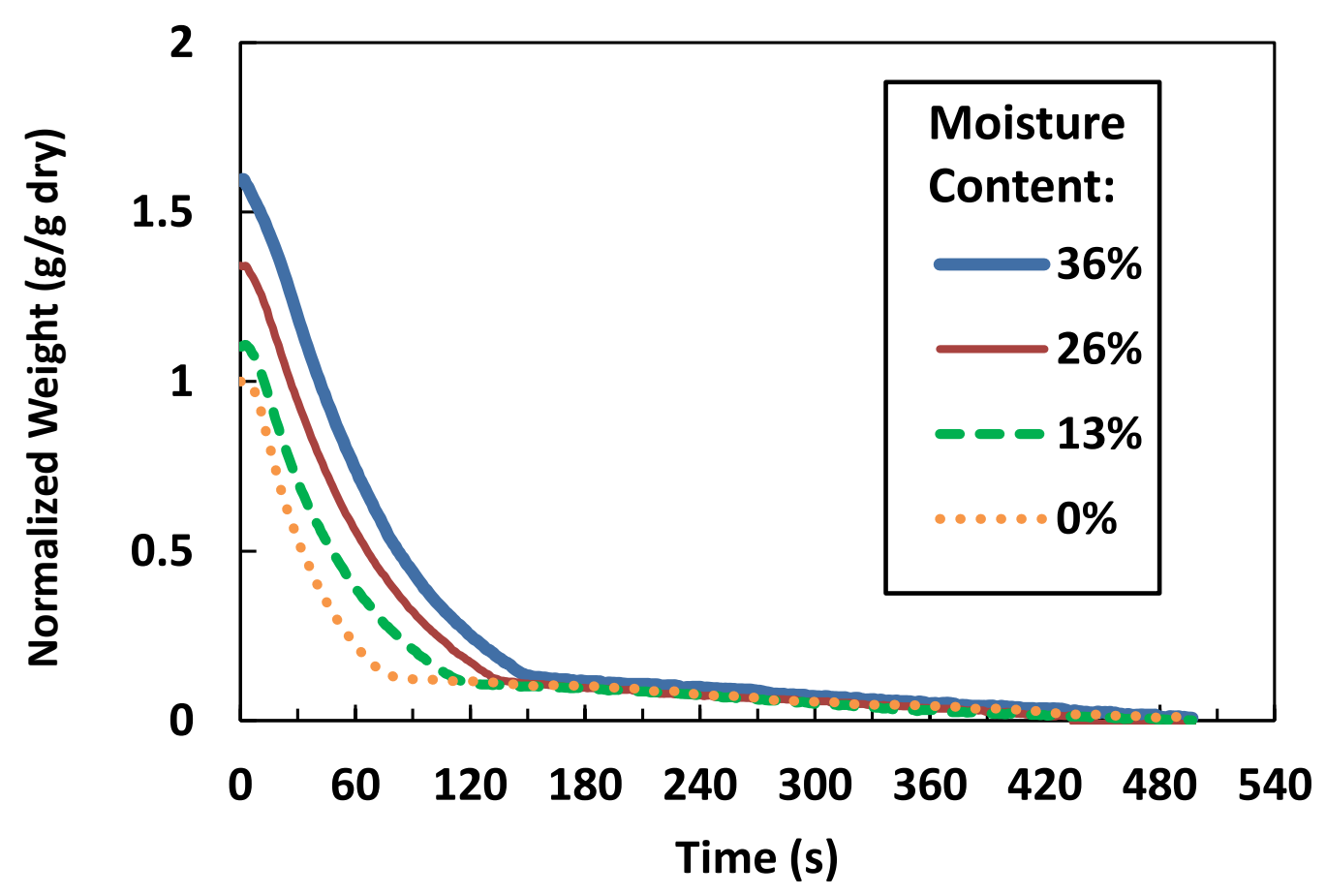

Figure A- 11. Weight change profile for combustion of maple at $800^{\circ} \mathrm{C}(1.75 \mathrm{~g}$ dry weight $)$

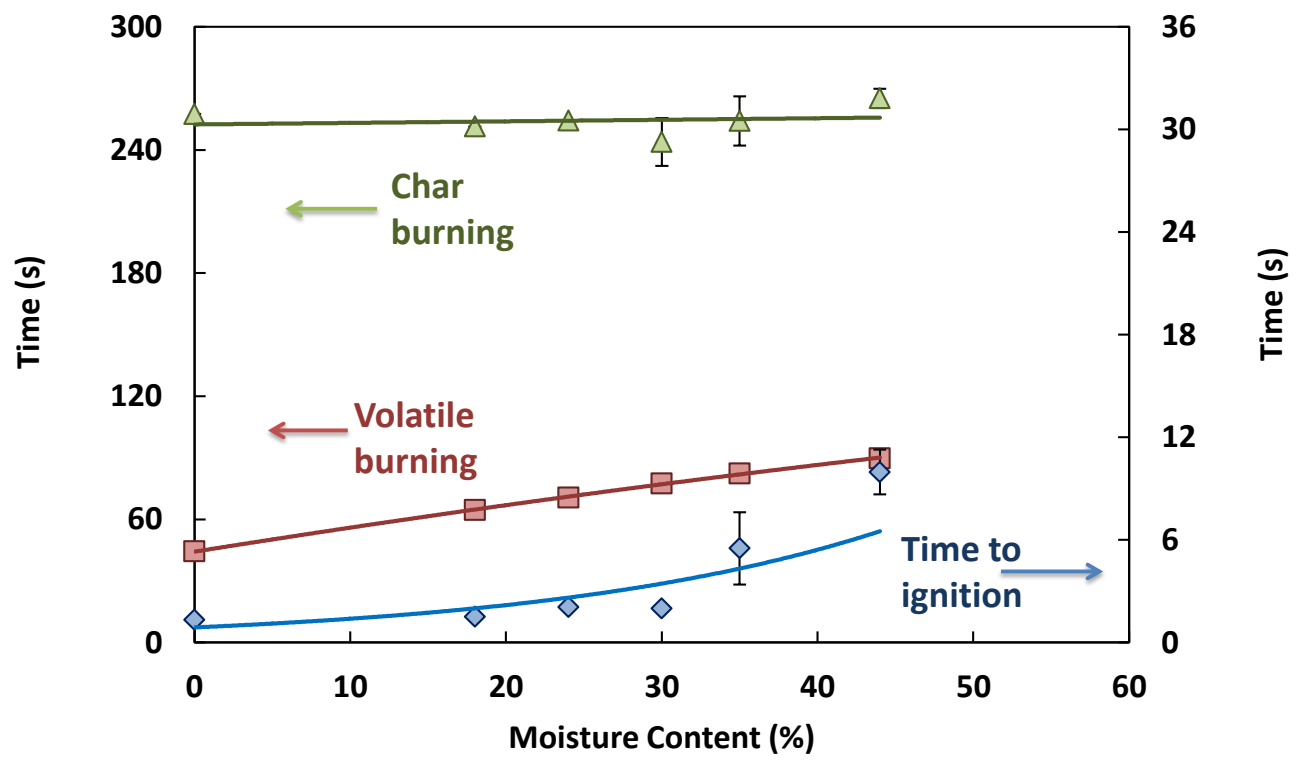

Figure A- 12. Combustion stages for maple at $800^{\circ} \mathrm{C}(1.34 \mathrm{~g}$ dry weight $)$ 


\section{Appendix 3. Effect of furnace temperature}

Furnace Temperature: $800^{\circ} \mathrm{C}$

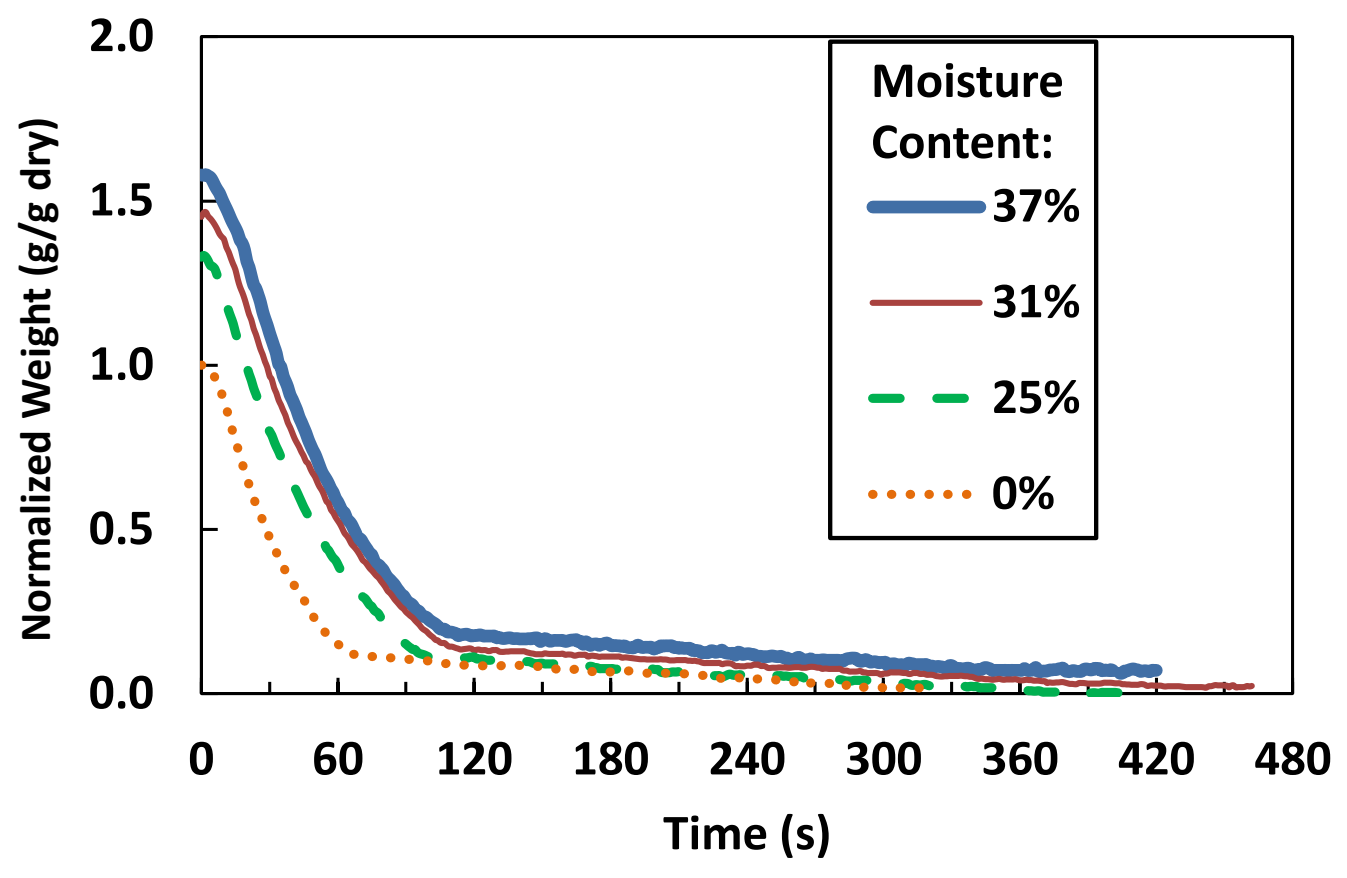

Figure A- 13. Weight change profile for combustion of oak at $800^{\circ} \mathrm{C}(1.34 \mathrm{~g}$ dry weight $)$ Furnace Temperature: $750^{\circ} \mathrm{C}$

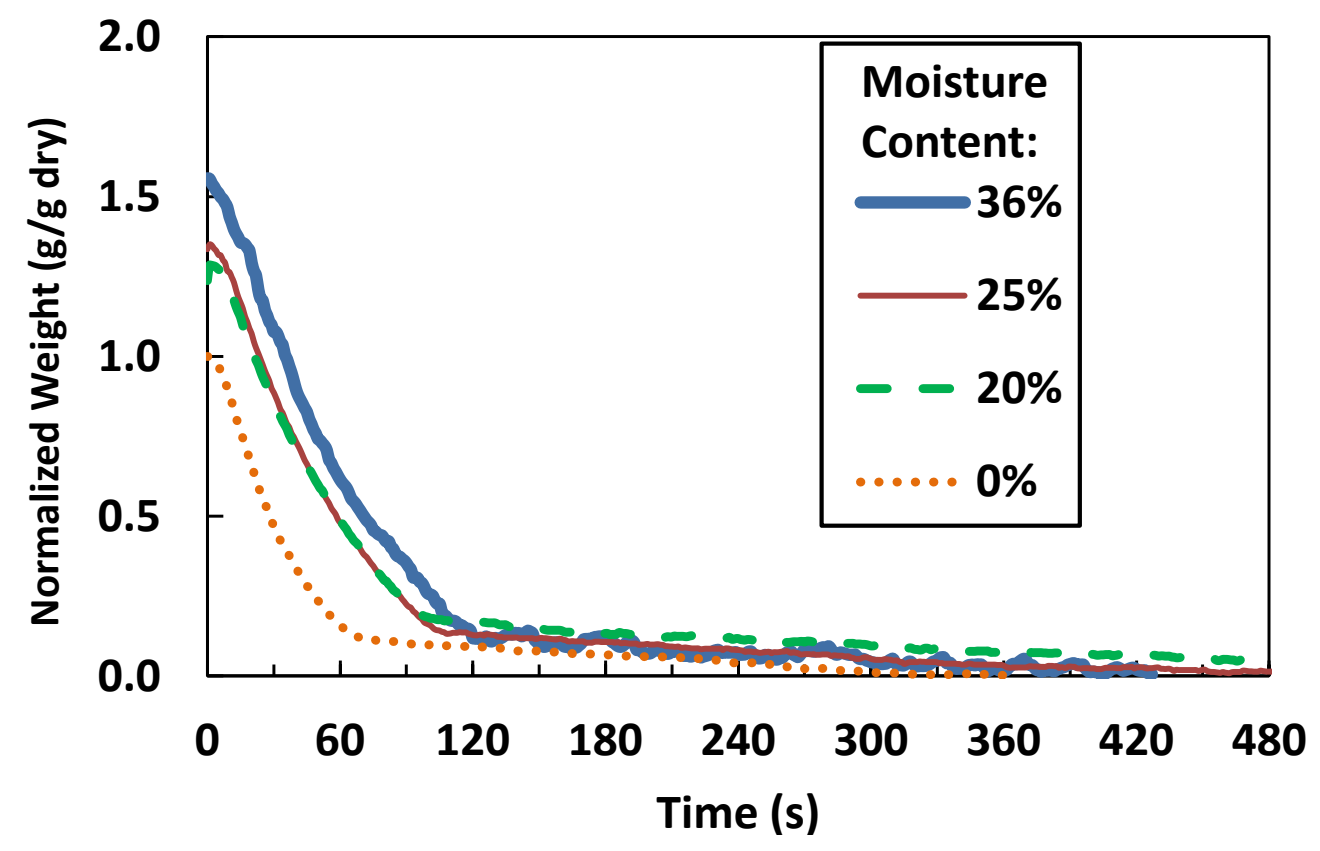

Figure A- 14. Weight change profile for combustion of oak at $750^{\circ} \mathrm{C}(1.34 \mathrm{~g}$ dry weight $)$ 
Furnace Temnerature $7 \mathrm{n}^{\circ} \mathrm{C}$

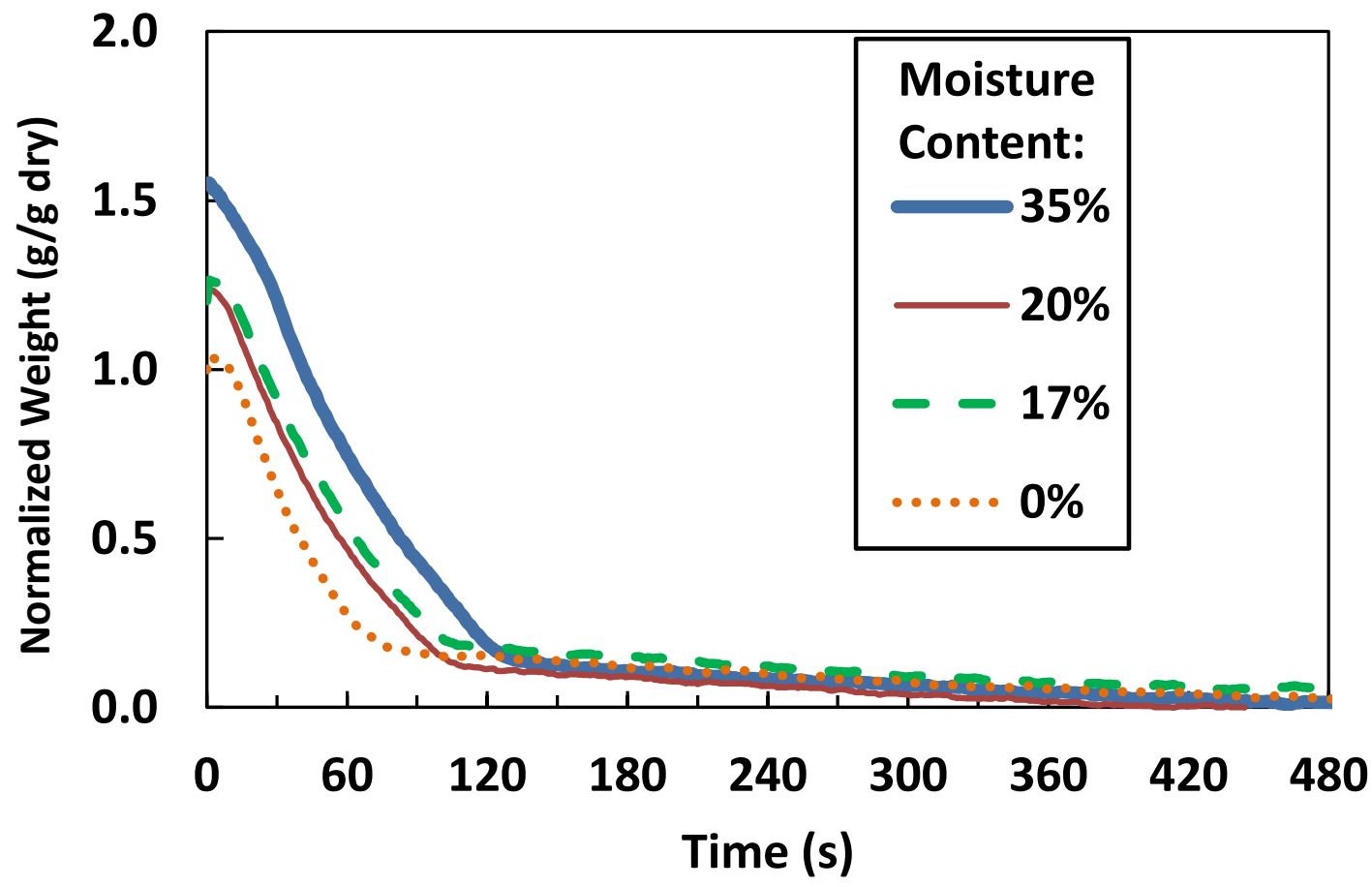

Figure A- 15. Weight change profile for combustion of oak at $700^{\circ} \mathrm{C}(1.34 \mathrm{~g}$ dry weight $)$ Furnace Temperature: $650^{\circ} \mathrm{C}$

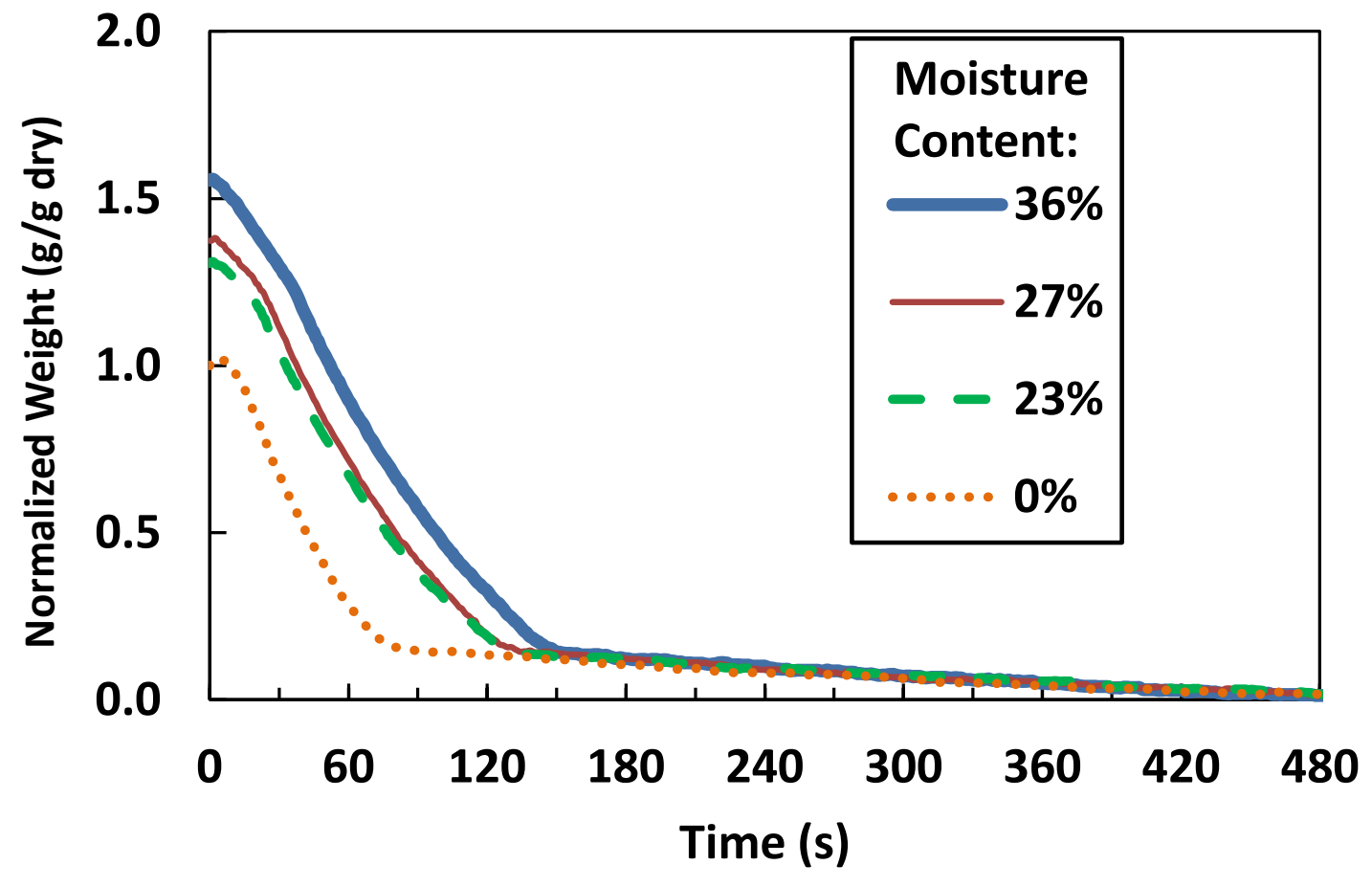

Figure A- 16. Weight change profile for combustion of oak at $650^{\circ} \mathrm{C}(1.34 \mathrm{~g}$ dry weight $)$ 
Furnace Temperature: $600^{\circ} \mathrm{C}$

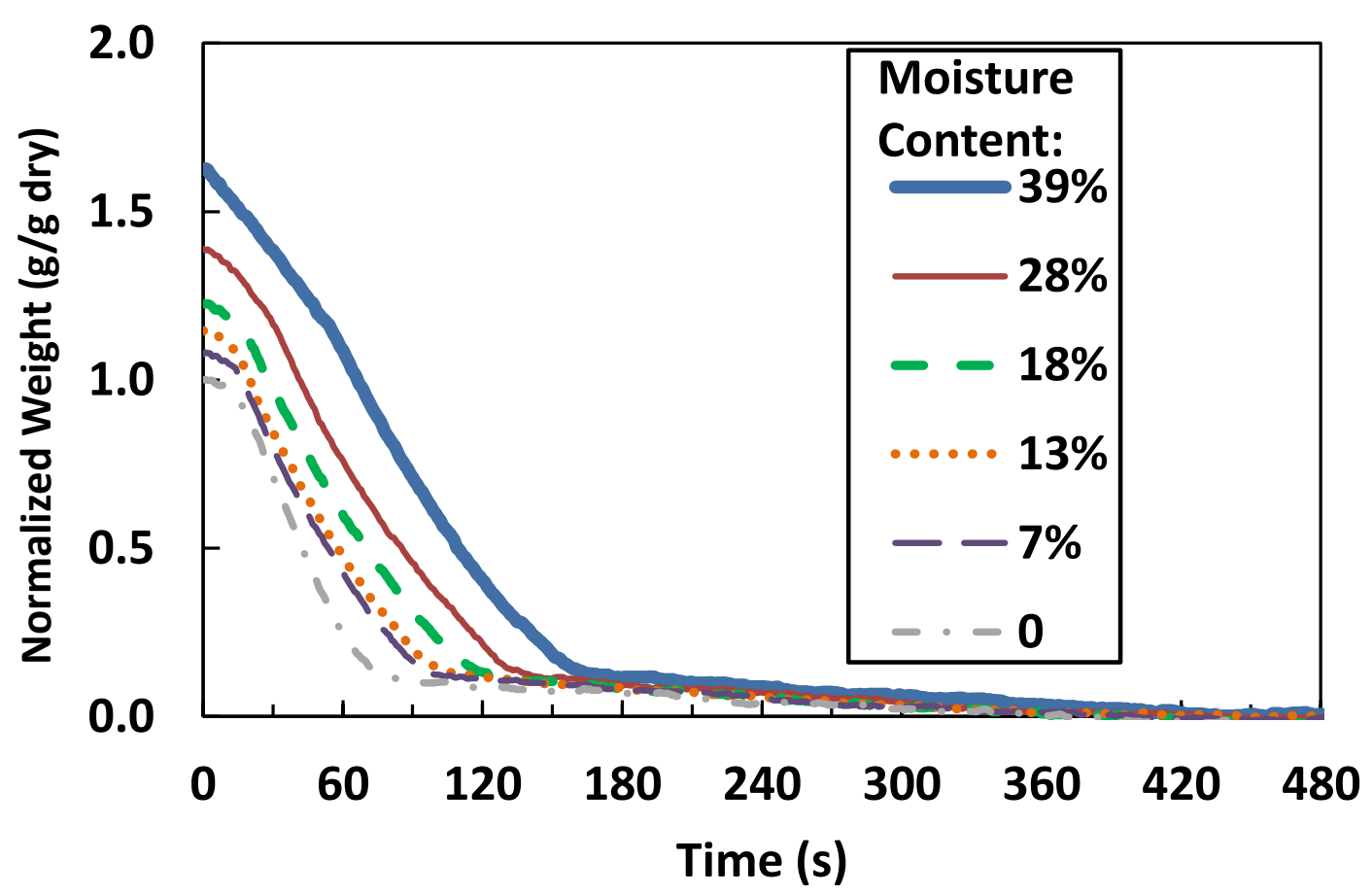

Figure A- 17. Weight change profile for combustion of oak at $600^{\circ} \mathrm{C}(1.34 \mathrm{~g}$ dry weight) Furnace Temperature: $550^{\circ} \mathrm{C}$

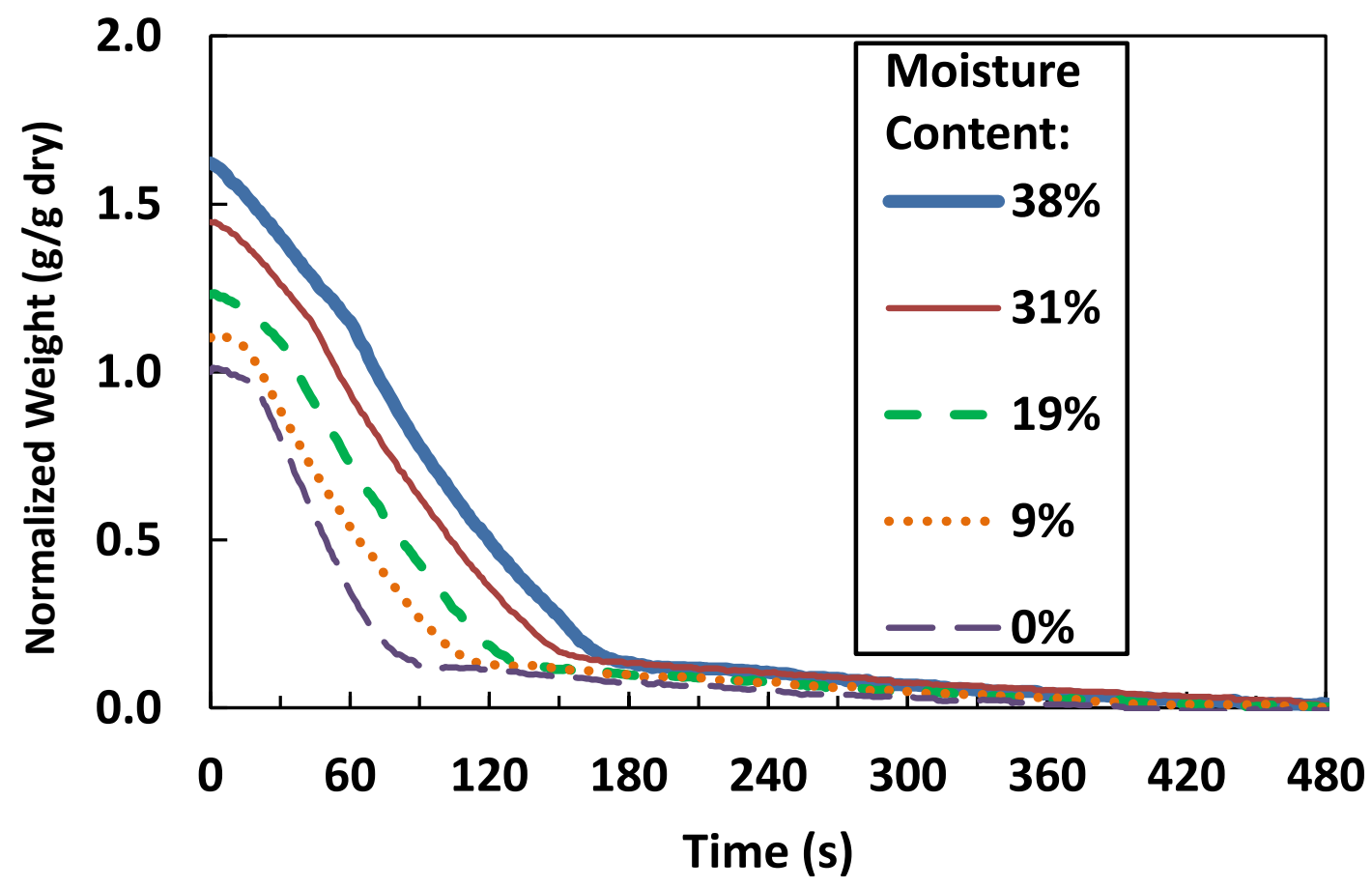

Figure A- 18. Weight change profile for combustion of oak at $550^{\circ} \mathrm{C}(1.34 \mathrm{~g}$ dry weight) 
Furnace Temperature: $500^{\circ} \mathrm{C}$

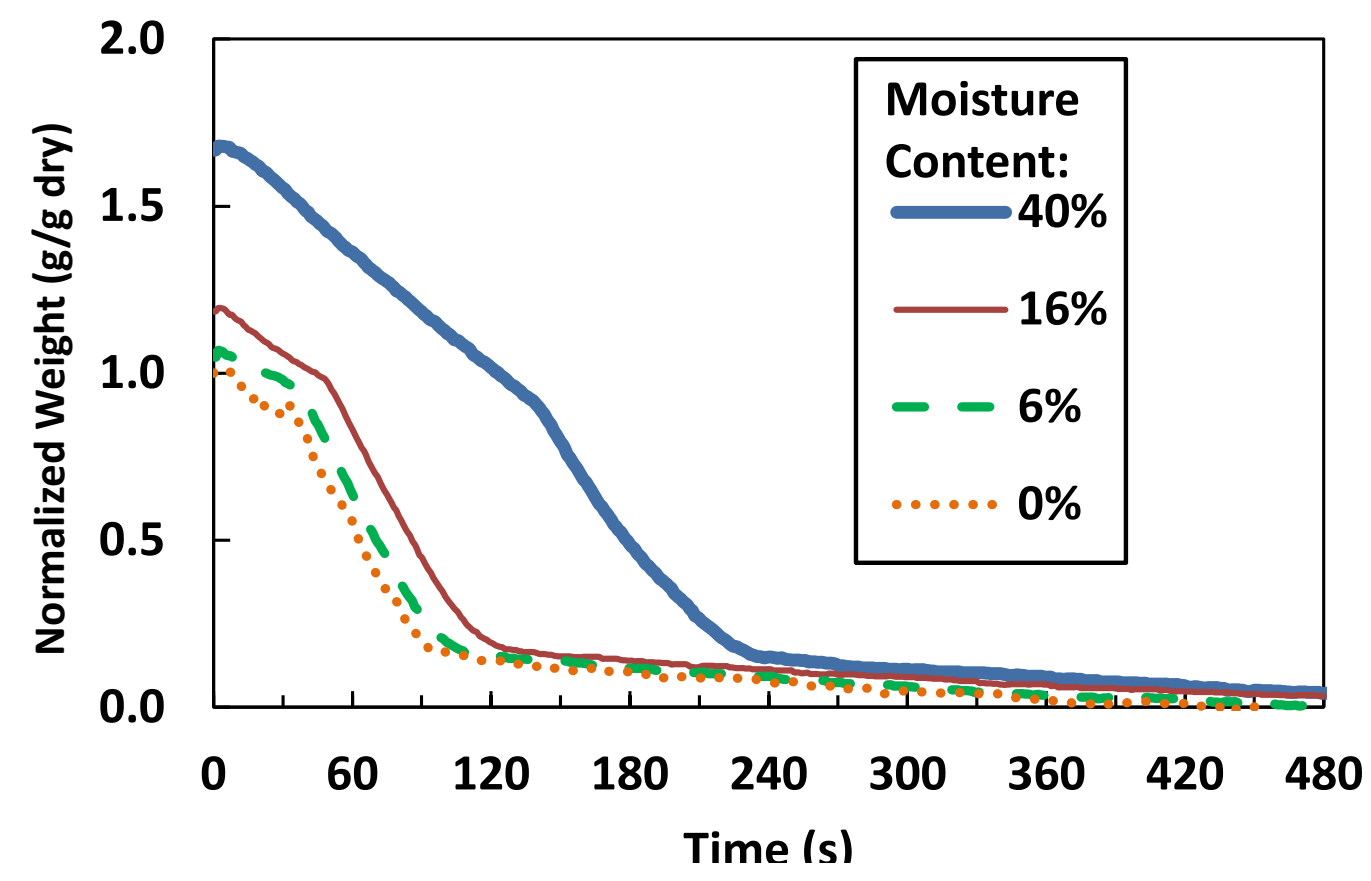

Figure A- 19. Weight change profile for combustion of oak at $500^{\circ} \mathrm{C}(1.34 \mathrm{~g}$ dry weight)

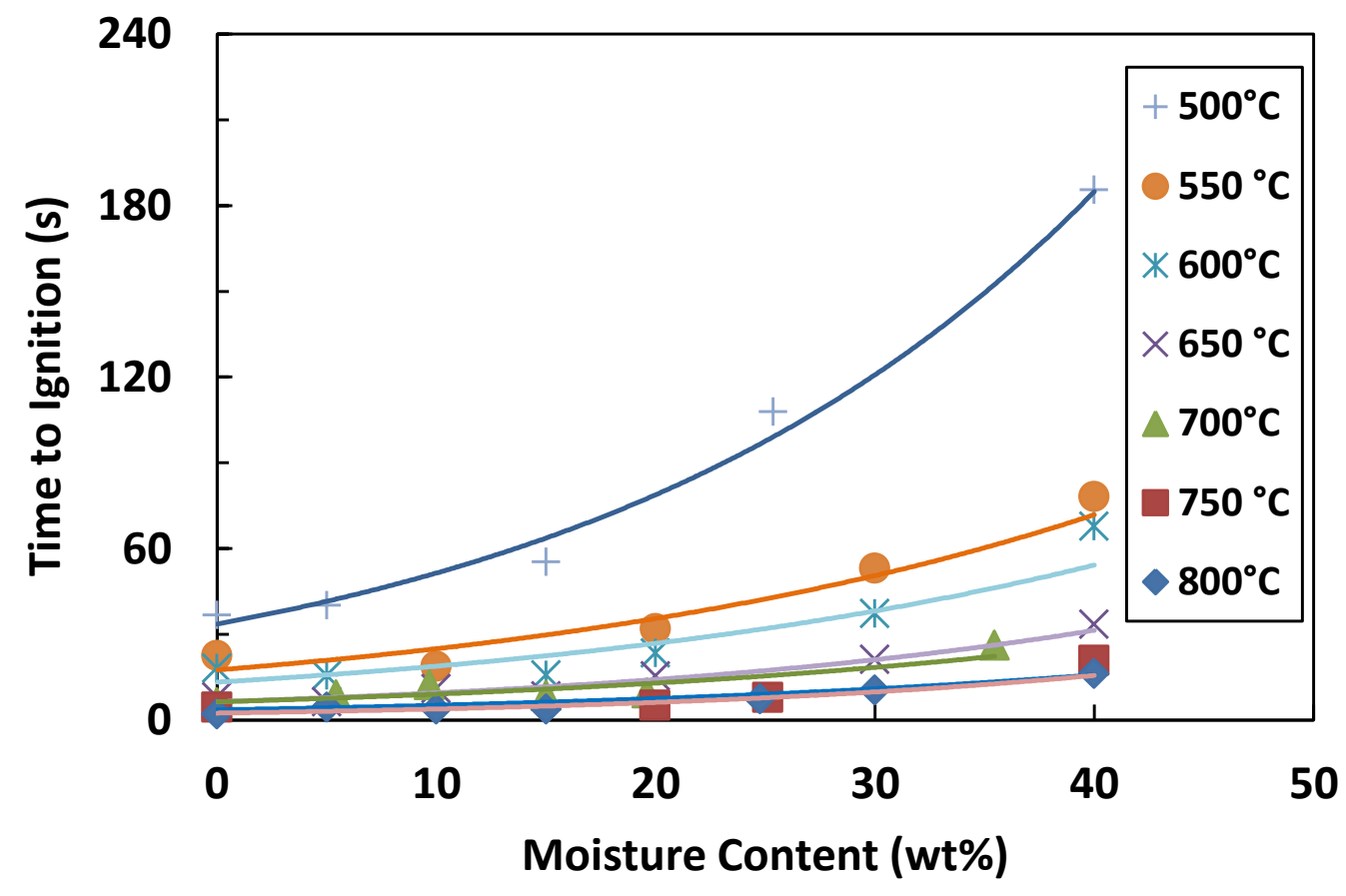

Figure A- 20. Effect of furnace temperature and moisture content on time-to-ignition (1.34 g dry sample) 


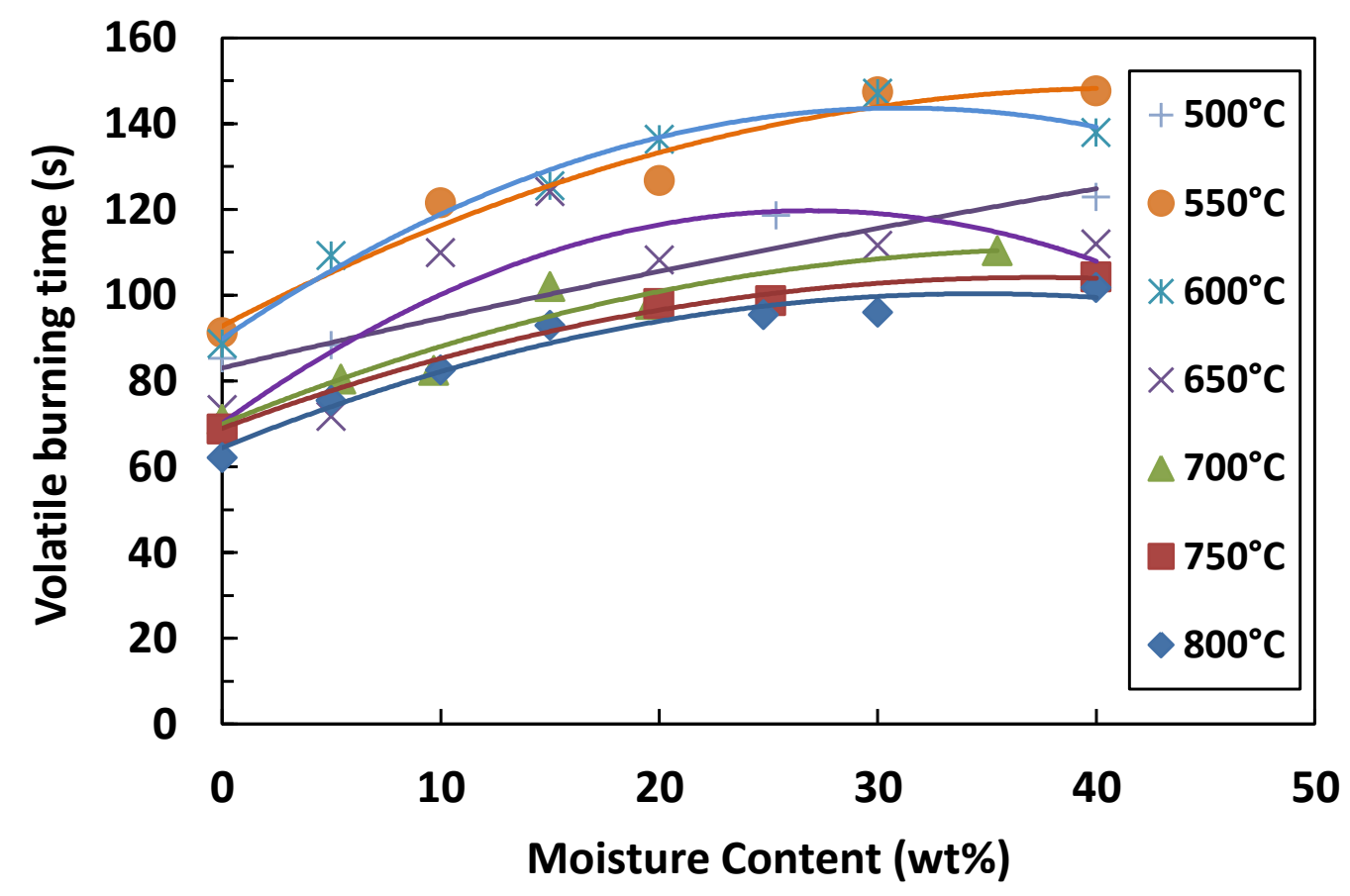

Figure A- 21. Effect of furnace temperature and moisture content on volatile burning time (1.34 g dry sample)

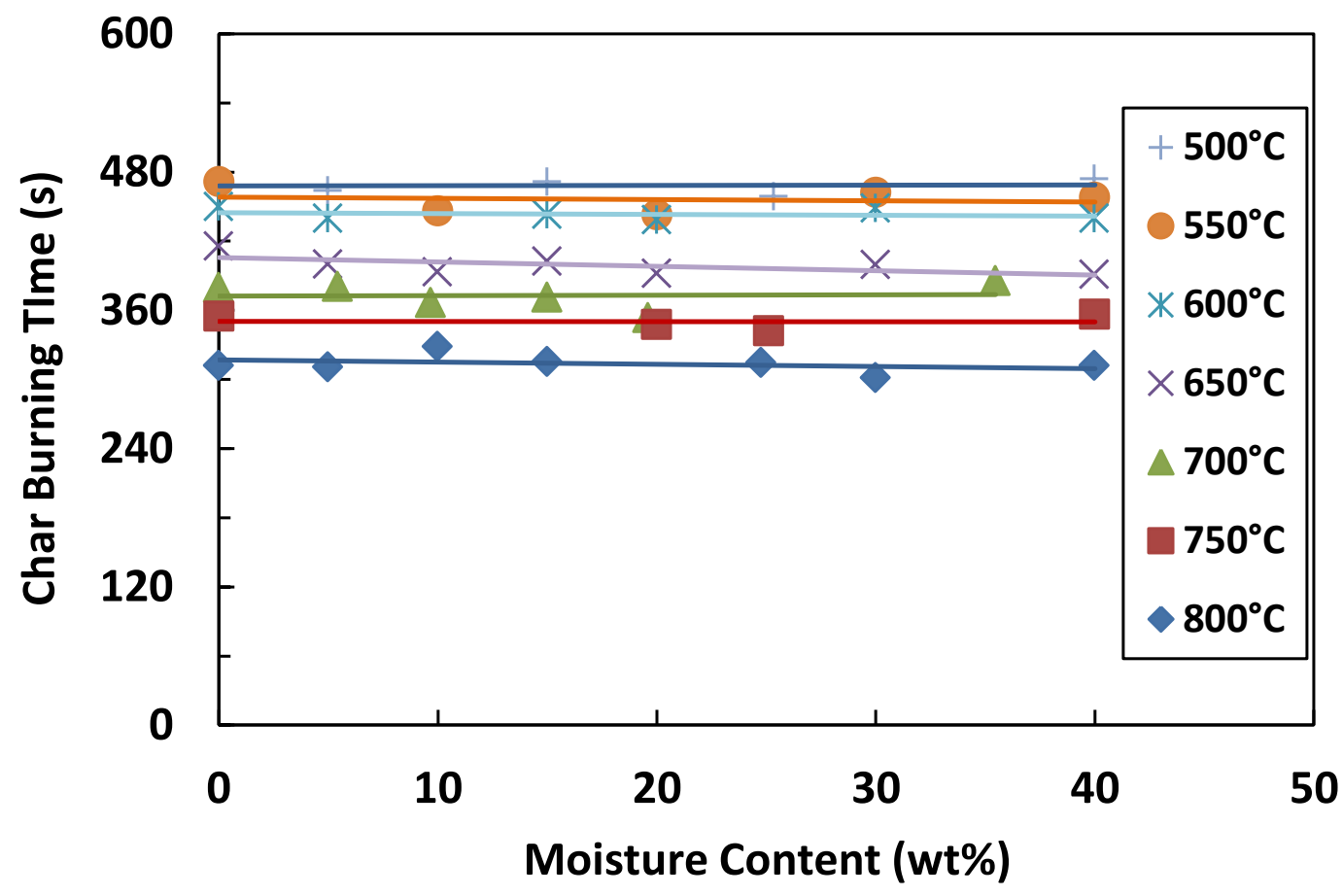

Figure A- 22. Effect of furnace temperature and moisture content on char burning time (1.34 g dry sample) 
Wood Species: Oak

Dry Weight: $1.34 \mathrm{~g}$

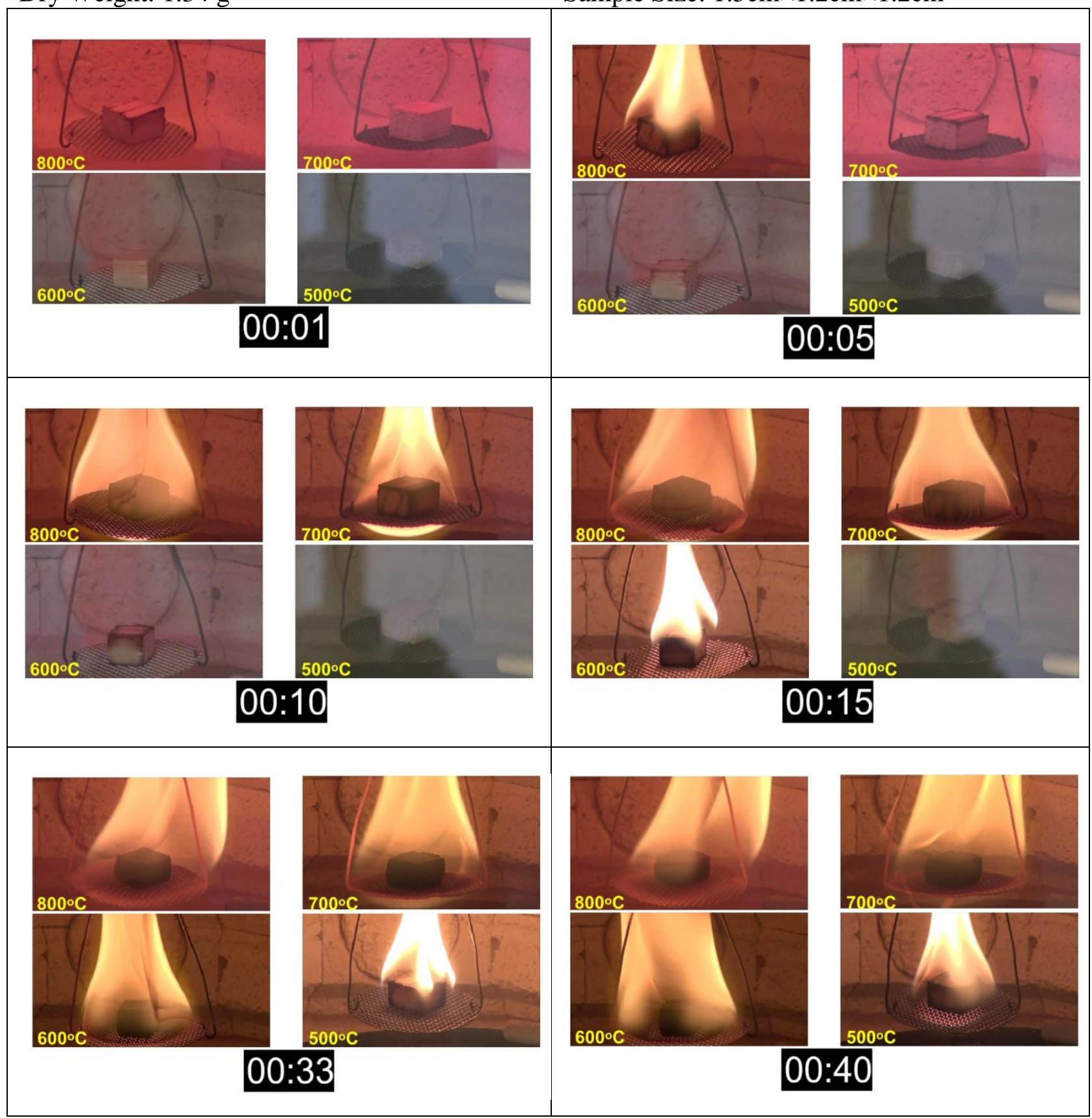

Moisture Content: 0\% (wet basis)

Sample Size: $1.5 \mathrm{~cm} \times 1.2 \mathrm{~cm} \times 1.2 \mathrm{~cm}$$$
\text { . }
$$ 


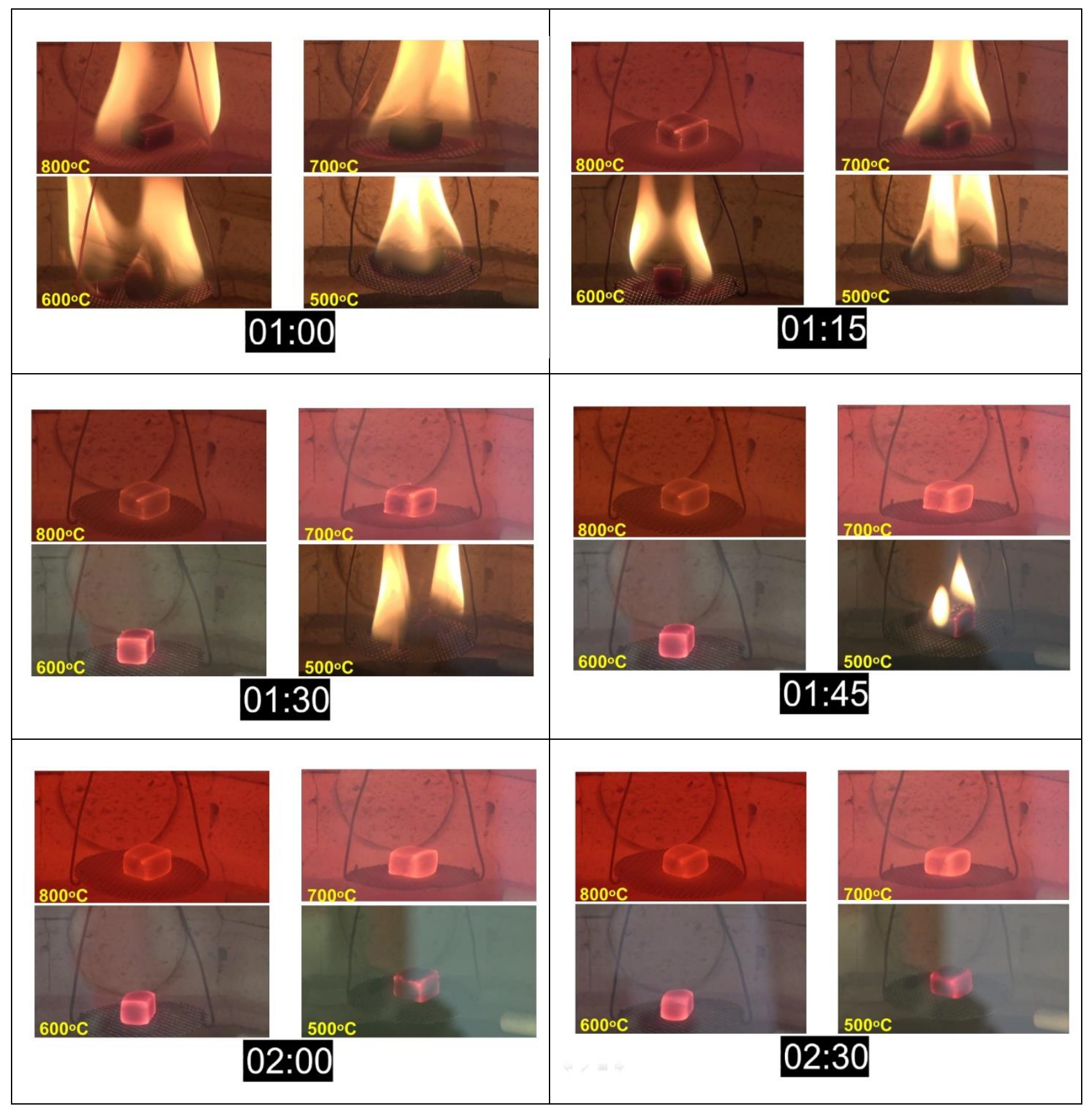




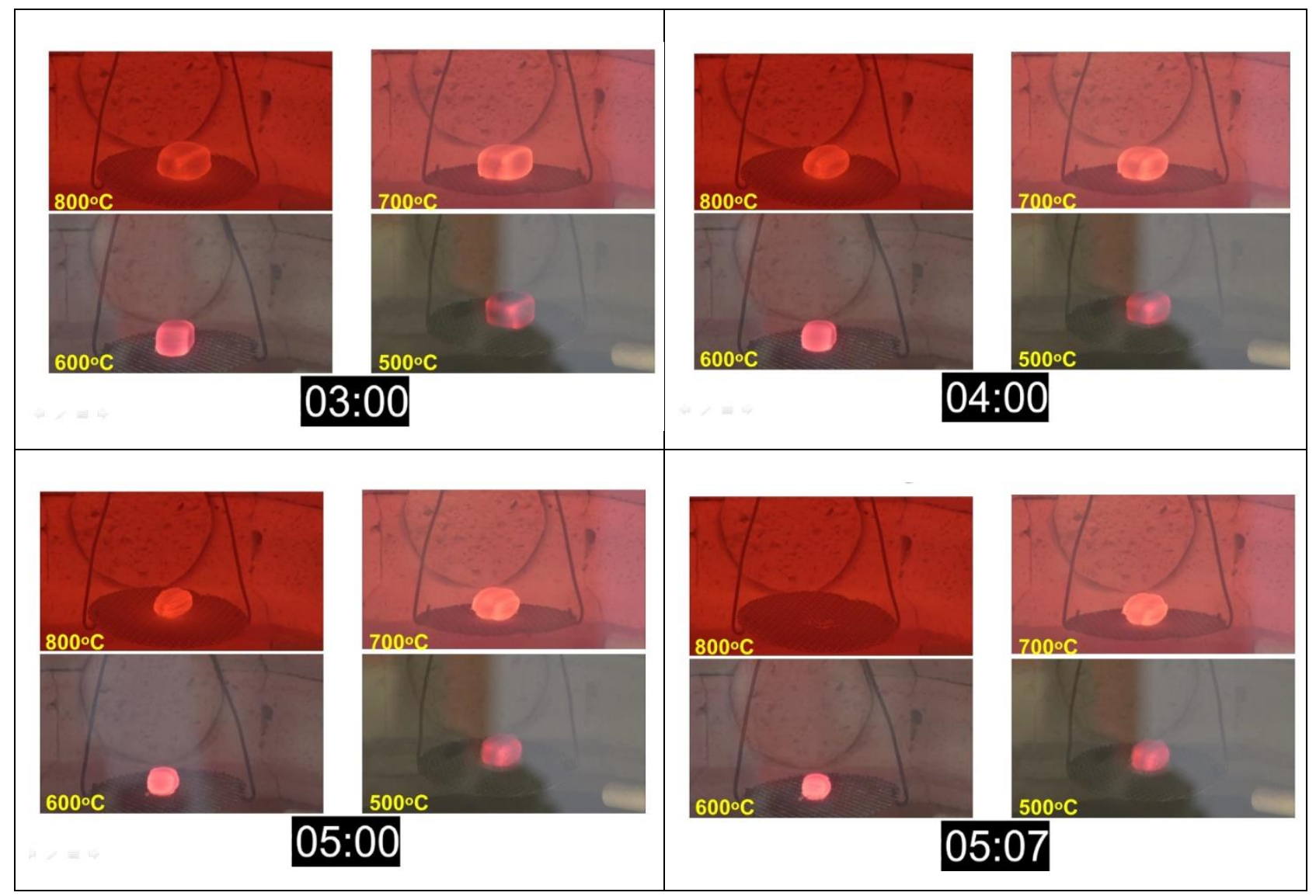

Figure A- 23. Combustion of oak with $0 \%$ moisture content at difference furnace temperatures (1.34 g dry sample) 
Wood Species: Oak

Dry Weight: $1.34 \mathrm{~g}$

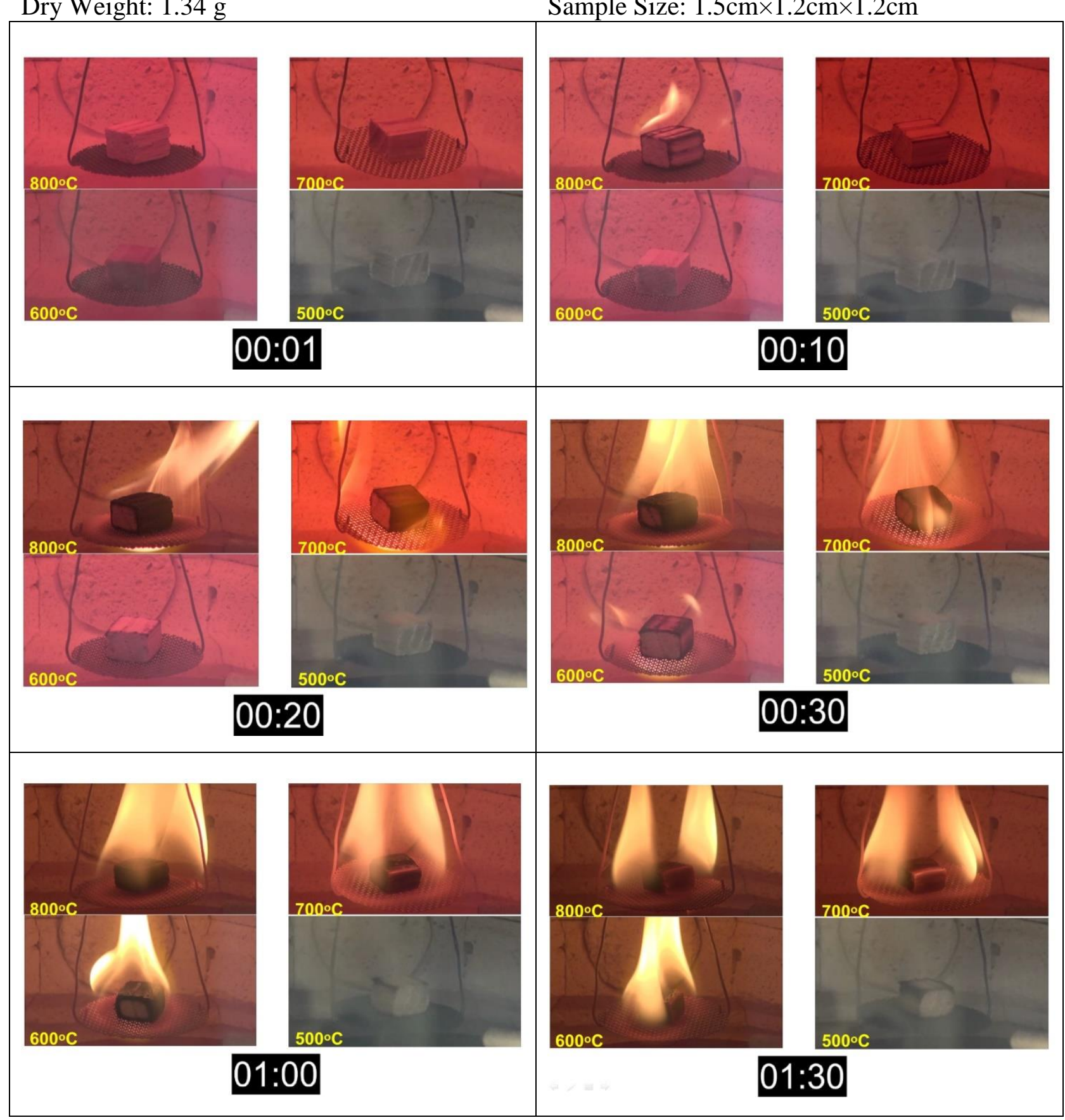




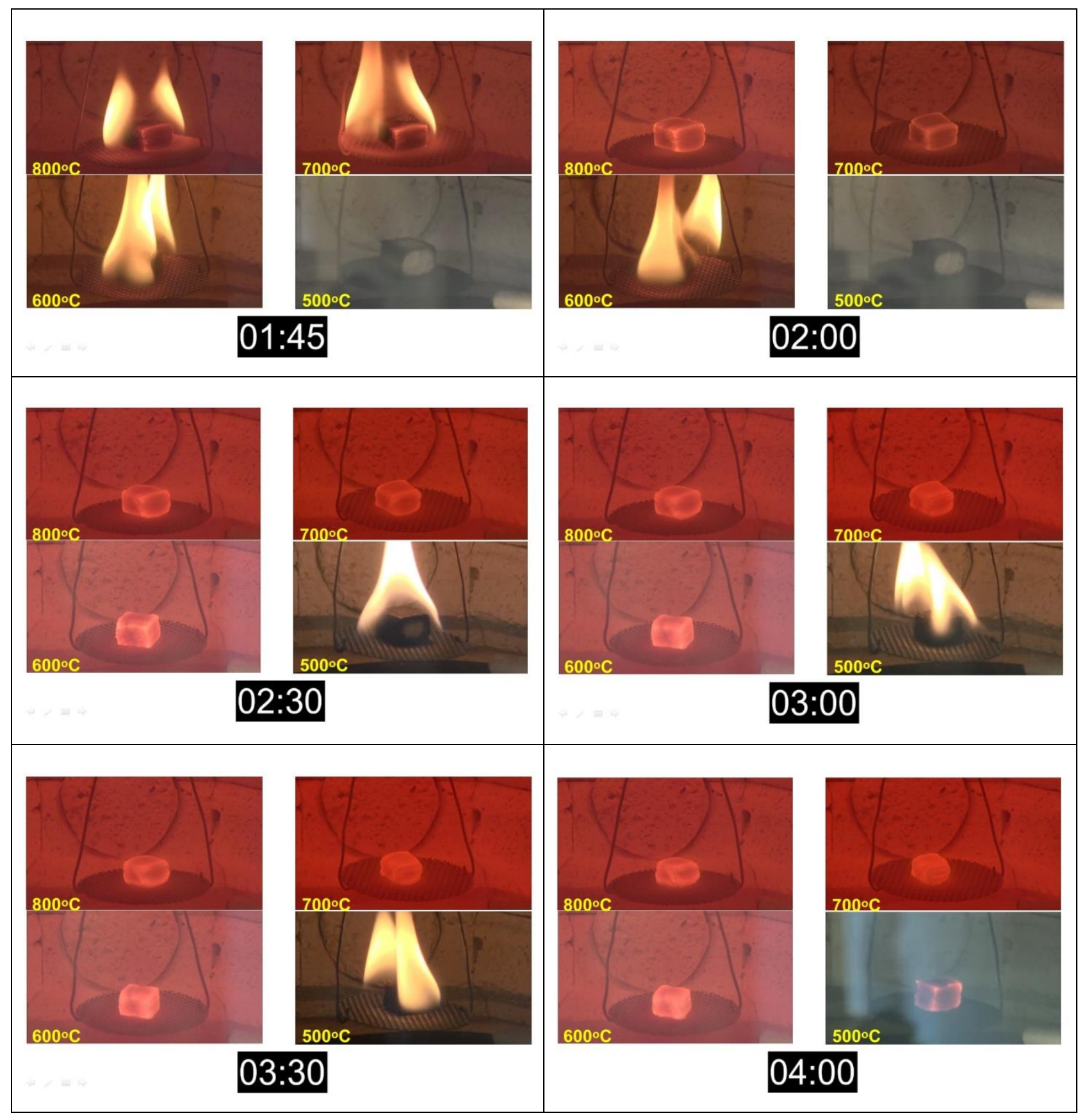




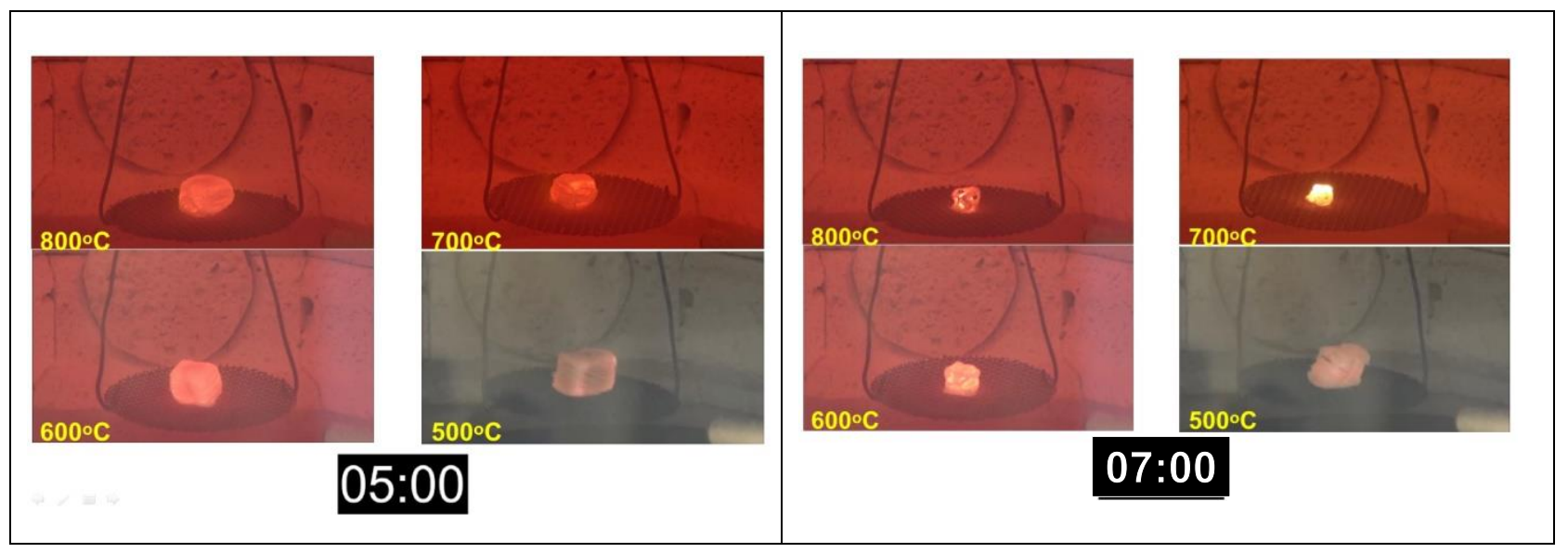

Figure A- 24. Combustion of oak with $40 \%$ moisture contenet at difference furnace

temperatures (1.34 g dry sample)

\section{Appendix 4. Field studies}

Input and output summary for material and energy balance

\begin{tabular}{|c|c|c|c|c|}
\hline \multicolumn{5}{|c|}{ Input Variables } \\
\hline Basis (tonnes/hr) & 28.50 & & & \\
\hline Moisture Content ( $\%$ dry basis) & 80.71 & MC wet basis $\%$ & 44.66 & \\
\hline Air Flow klb & 455.88 & & & \\
\hline Natural Gas Flow kscf & 16.30 & Air Flow klb & 0 & \\
\hline Fuel Oil Flow klb/hr & 4.40 & Air Flow klb & 0.00 & \\
\hline Waste Oil Flow L/min & 0.00 & & & \\
\hline Heated Air & Inlet Temperature $\left({ }^{\circ} \mathrm{F}\right)$ & 63.82 & Outlet Temperature $\left({ }^{\circ} \mathrm{F}\right)$ & 392.16 \\
\hline Gas Product & Outlet Temperature $\left({ }^{\circ} \mathrm{F}\right)$ & 392.16 & & \\
\hline Steam & Inlet Temperature ( $\left.{ }^{\circ} \mathrm{F}\right)$ & 63.82 & Outlet Temperature $\left({ }^{\circ} \mathrm{F}\right)$ & 819.88 \\
\hline Steam Flow klb & 203.54 & & & \\
\hline \multicolumn{5}{|c|}{ Output Summary } \\
\hline Total Air & 455.88 & & & \\
\hline Excess Air Volume \% & 119.18 & Excess $\mathrm{O} 2$ & 7.69 & \\
\hline Steam Flow klb & 203.54 & & & \\
\hline
\end{tabular}

Figure A- 25. Summary of material and energy balance

1. $Q_{\text {in }}=Q_{\text {biomass }}+Q_{\text {fossil fuel }}$

2. $Q_{\text {loss }}=Q_{\text {flue gas }}+Q_{\text {air }}+Q_{M C}+Q_{\text {radiation }}+Q_{\text {ash }}+Q_{\text {unaccounted }}$

3. $Q_{\text {steam }}=Q_{\text {in }}-Q_{\text {loss }}$

Substituting equation 1 and 2 into equation 3 and expanding all the terms: 


$$
\begin{aligned}
& m_{\text {steam }}\left(C_{\text {latent }}+C_{p \text { steam }}\left(T_{\text {Final }}-100\right)+C_{p \text { water }}\left(100-T_{\text {initial }}\right)\right)+ \\
& m_{\text {flue gas }} C_{p \text { flue gas }}\left(T_{\text {final }}-T_{\text {initial }}\right)= \\
& \left(m_{\text {biomass }} q_{\text {biomass }}+m_{\text {fossil fuel }} C_{p \text { fossiel fuel }}\right)-\left(m_{\text {air }} C_{p \text { air }}\left(T_{\text {final }}-T_{\text {initial }}\right)+\right. \\
& M C m_{\text {biomass }} C_{p \text { water }}\left(T_{\text {final }}-100\right)+M C m_{\text {biomass }} C_{\text {latent }}+ \\
& \left.M C m_{\text {biomass }} C_{p \text { water }}\left(100-T_{\text {initial }}\right)+0.12 Q_{\text {total input }}\right)
\end{aligned}
$$

For the values shown in the summary above, the following calculations were done to find the moisture content value:

Table A- 3. Material balance for biomass combustion

\begin{tabular}{|c|c|c|c|}
\hline Composition & (\% dry basis) & Amount $(\mathbf{k g} / \mathbf{h r})$ & $\begin{array}{c}\text { Required Oxygen } \\
\text { (kg/hr) }\end{array}$ \\
\hline Carbon & 52.00 & 7439.85 & 19839.59 \\
\hline Hydrogen & 6.50 & 929.98 & 7439.85 \\
\hline Sulfur & 0.00 & 0.00 & 0.00 \\
\hline Nitrogen & 0.31 & 44.35 & 0.00 \\
\hline Oxygen & 37.68 & 5391.03 & 0.00 \\
\hline Chlorine & 0.01 & 1.43 & \\
\hline Ash & 3.50 & 500.76 & 27279.44 \\
\hline Total Dry Mass & 100.00 & 14307.40 & \\
\hline
\end{tabular}

Table A- 4. Calculations for amount of required oxygen and air

\begin{tabular}{|c|c|c|c|}
\hline Oxygen Required & & $\mathrm{kg} / \mathrm{kg}$ feed & 1.53 \\
\hline Air Required & & $\mathrm{kg}$ air/kg dry biomass & 6.59 \\
\hline Excess Air volume \% & 119.18 & $\mathrm{~kg} \mathrm{air} / \mathrm{kg}$ dry biomass & 14.45 \\
\hline Excess Oxygen & & $\mathrm{kg} \mathrm{O} 2 / \mathrm{kg}$ dry biomass & 3.35 \\
\hline
\end{tabular}


Table A- 5. Calculations for flue gas composition

\begin{tabular}{|l|l|l|l|l|}
\hline Product & Amount $\mathbf{( k g / h r})$ & $\%$ & Volume (m3) & \% \\
\hline CO2 & 27279.44 & 11.74 & 14809.69 & $7.57 \%$ \\
\hline H2O & 19917.20 & 8.57 & 24772.64 & $12.66 \%$ \\
\hline SO2 & 0.00 & 0.00 & 0.00 & $0.00 \%$ \\
\hline N2 & 159270.47 & 68.55 & 136712.85 & $69.85 \%$ \\
\hline O2 & 25861.33 & 11.13 & 19430.00 & $9.93 \%$ \\
\hline Total & 232328.44 & 100.00 & 195725.18 & $100.00 \%$ \\
\hline kg Flue gas/kg feed & 16.24 & & 100619 & \\
\hline
\end{tabular}

Table A- 6. Calculation for heat of formation

\begin{tabular}{|c|c|c|c|}
\hline & $\begin{array}{c}\text { Heat of } \\
\text { formation } \\
(\mathrm{kJ} / \mathrm{mol})\end{array}$ & $\begin{array}{c}\text { Heat of } \\
\text { formation } \\
(\mathrm{kJ} / \mathrm{kg})\end{array}$ & $\begin{array}{c}\text { Heat of formation } \\
\text { (MJ) }\end{array}$ \\
\hline $\begin{array}{c}\mathrm{C}+\mathrm{O} 2=>\mathrm{CO} 2 \\
(12 \mathrm{~kg} \mathrm{C})+(32 \mathrm{~kg} O)=>(44 \mathrm{~kg} \mathrm{CO})\end{array}$ & 393.50 & 32791.67 & 243964.99 \\
\hline $\begin{array}{c}2 \mathrm{H} 2+\mathrm{O} 2=>2 \mathrm{H} 2 \mathrm{O} \\
(4 \mathrm{~kg} \mathrm{H})+(32 \mathrm{~kg} \mathrm{O})=>(36 \mathrm{~kg} \mathrm{H} 2 \mathrm{O})\end{array}$ & 285.82 & 142910.00 & 132903.57 \\
\hline $\begin{array}{c}\mathrm{S}+\mathrm{O} 2=>\mathrm{SO} 2 \\
(32 \mathrm{~kg} \mathrm{~S})+(32 \mathrm{~kg} \mathrm{O}) \Rightarrow>(64 \mathrm{~kg} \mathrm{SO} 2)\end{array}$ & 296.70 & 9271.88 & 0.00 \\
\hline
\end{tabular}


Table A- 7. Energy inputs for heat balance

\begin{tabular}{|c|c|c|}
\hline \multicolumn{3}{|c|}{ Energy Input } \\
\hline & Heat Input (MJ) & \% Total Heat Input \\
\hline Biomass & 364670.31 & 76.62 \\
\hline Natural Gas & 21504.50 & 4.52 \\
\hline Fuel Oil & 89757.63 & 18.86 \\
\hline Total & 475932.44 & 100.00 \\
\hline
\end{tabular}

Table A- 8. Energy loss for heat balance

\begin{tabular}{|c|c|c|}
\hline \multicolumn{2}{|l|}{ Energy Loss } \\
\hline Heat Loss (MJ) & \% Total Heat Input \\
\hline Heated Air & 45415.21 & 9.54 \\
\hline Moisture Content of Biomass & & \\
\hline Sensible Heat & 3626.16 & 0.76 \\
\hline Latent Heat & 26212.54 & 5.51 \\
\hline Radiation Heat Loss & 4759.32 & 1.00 \\
\hline Fly Ash & 149.25 & 0.03 \\
\hline Bottom Ash & 112.84 & 0.02 \\
\hline Unaccounted & 47593.24 & 10.00 \\
\hline Total & 127868.57 & 26.87 \\
\hline
\end{tabular}


Table A- 9. Energy output for heat balance

\begin{tabular}{|c|c|c|}
\hline \multicolumn{2}{|c|}{ Energy Output } \\
\hline Total & $\begin{array}{c}\text { Heat Output } \\
\text { (MJ) }\end{array}$ & $\begin{array}{c}\text { \%otal Heat } \\
\text { Input }\end{array}$ \\
\hline Gas Product Heat & 348063.87 & 73.13 \\
\hline Sensible Heat of Water in Tube Banks & 44426.24 & 9.33 \\
\hline Heat Available for Steam Production & 31823.26 & 6.69 \\
\hline Amoat of Water in Tube Banks & 209580.28 & 44.04 \\
\hline kET STEAM TEMPERATURE: Final Temperature ${ }^{\circ}{ }^{\circ}$ C) & 437.71 & 63.80 \\
\hline klb & 92326.11 & \\
\hline Amount of Steam kg & 203.54 & \\
\hline
\end{tabular}




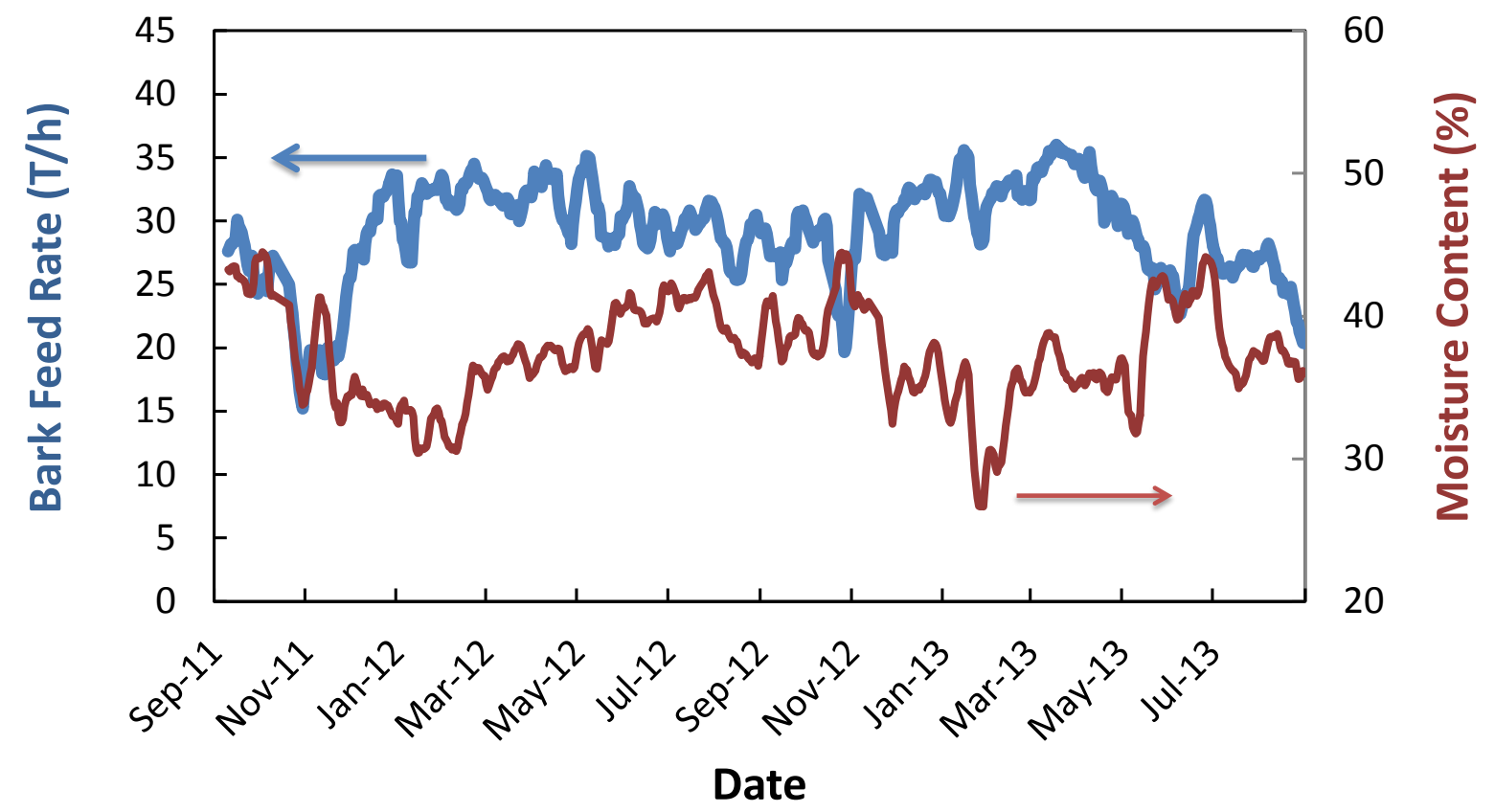

Figure A- 26.Changes of bark feed rate and moisture content with time for Mill A

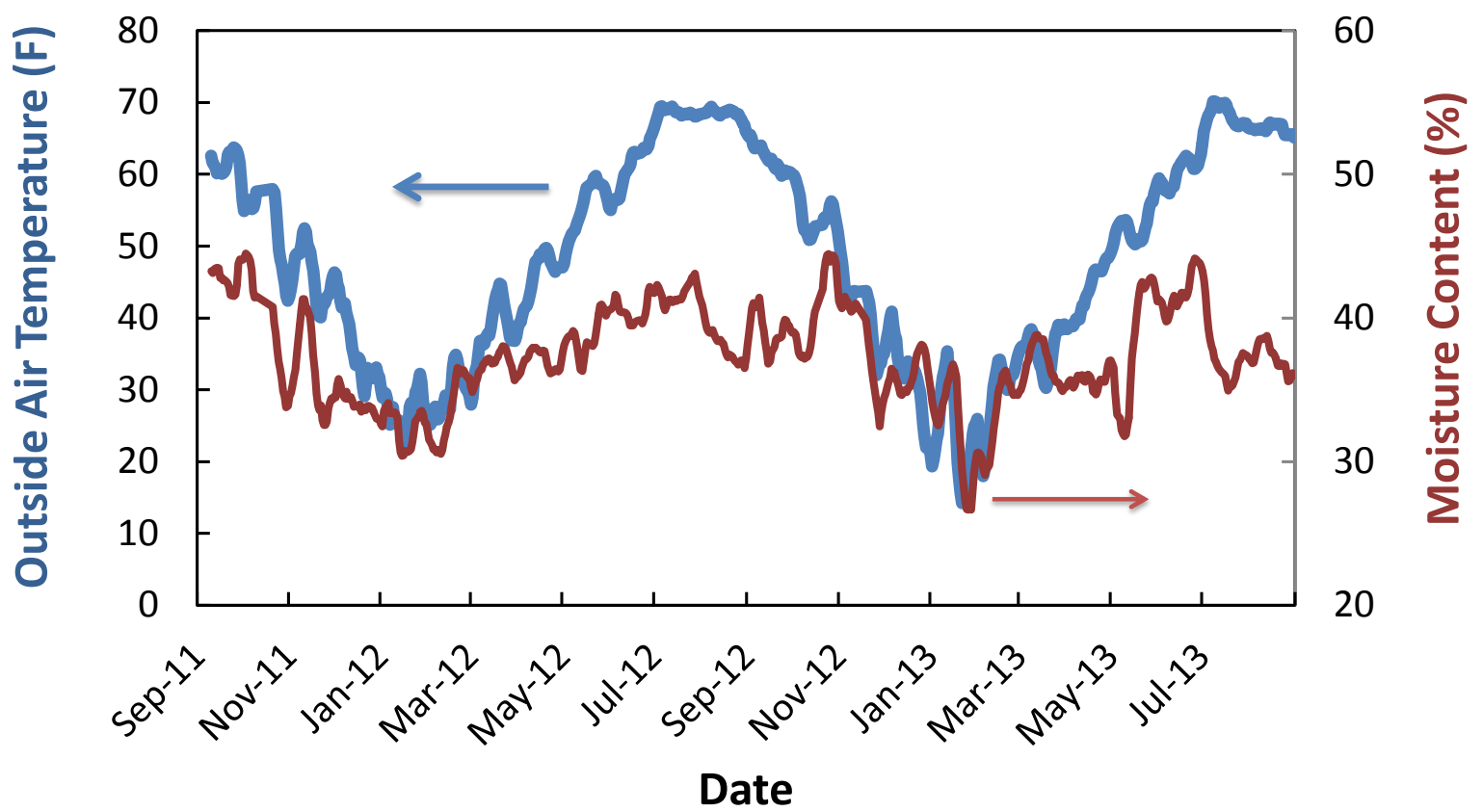

Figure A- 27. Changes of outside air temperature and moisture content with time for Mill A 


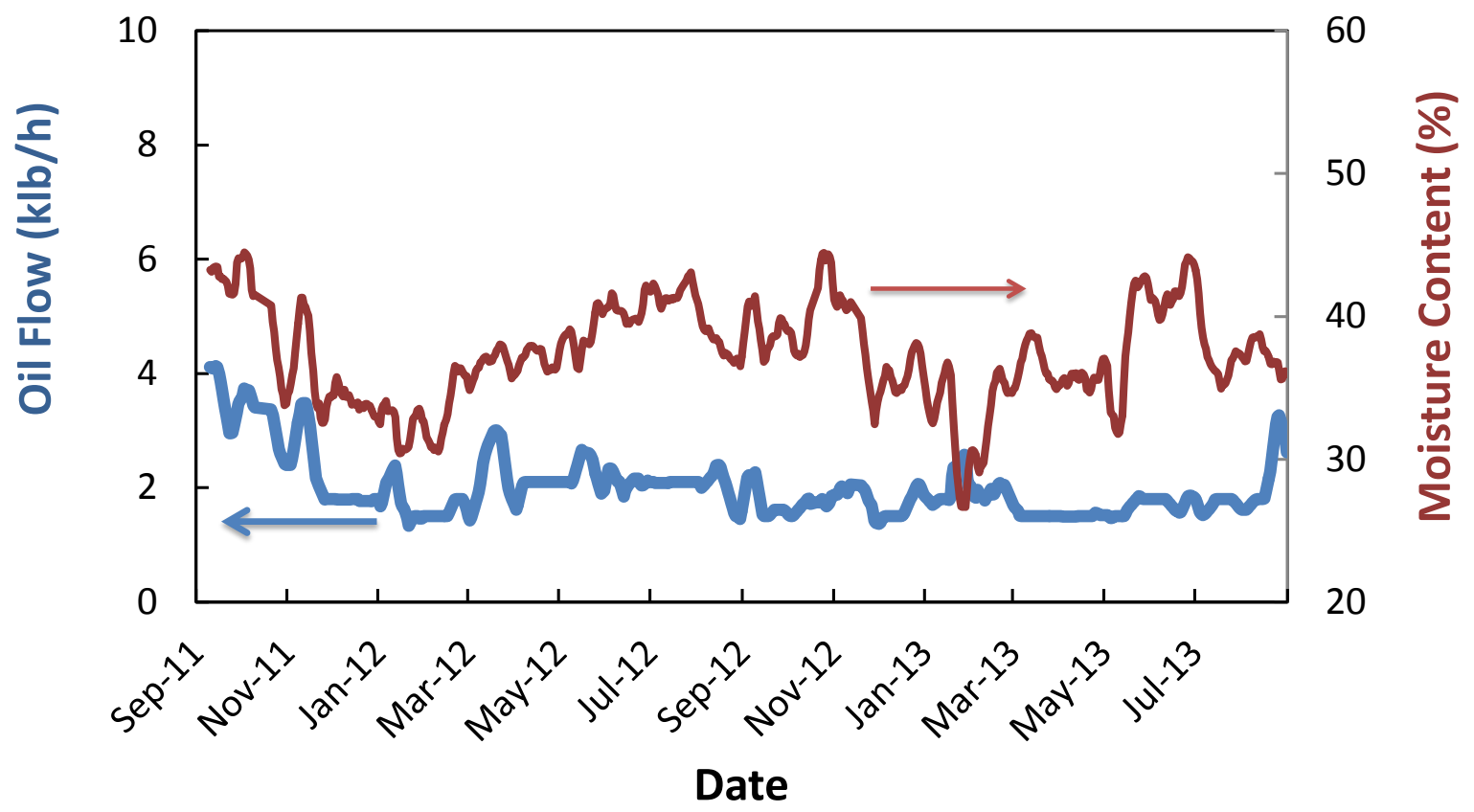

Figure A- 28. Changes of oil flow rate and moisture content with time for Mill A

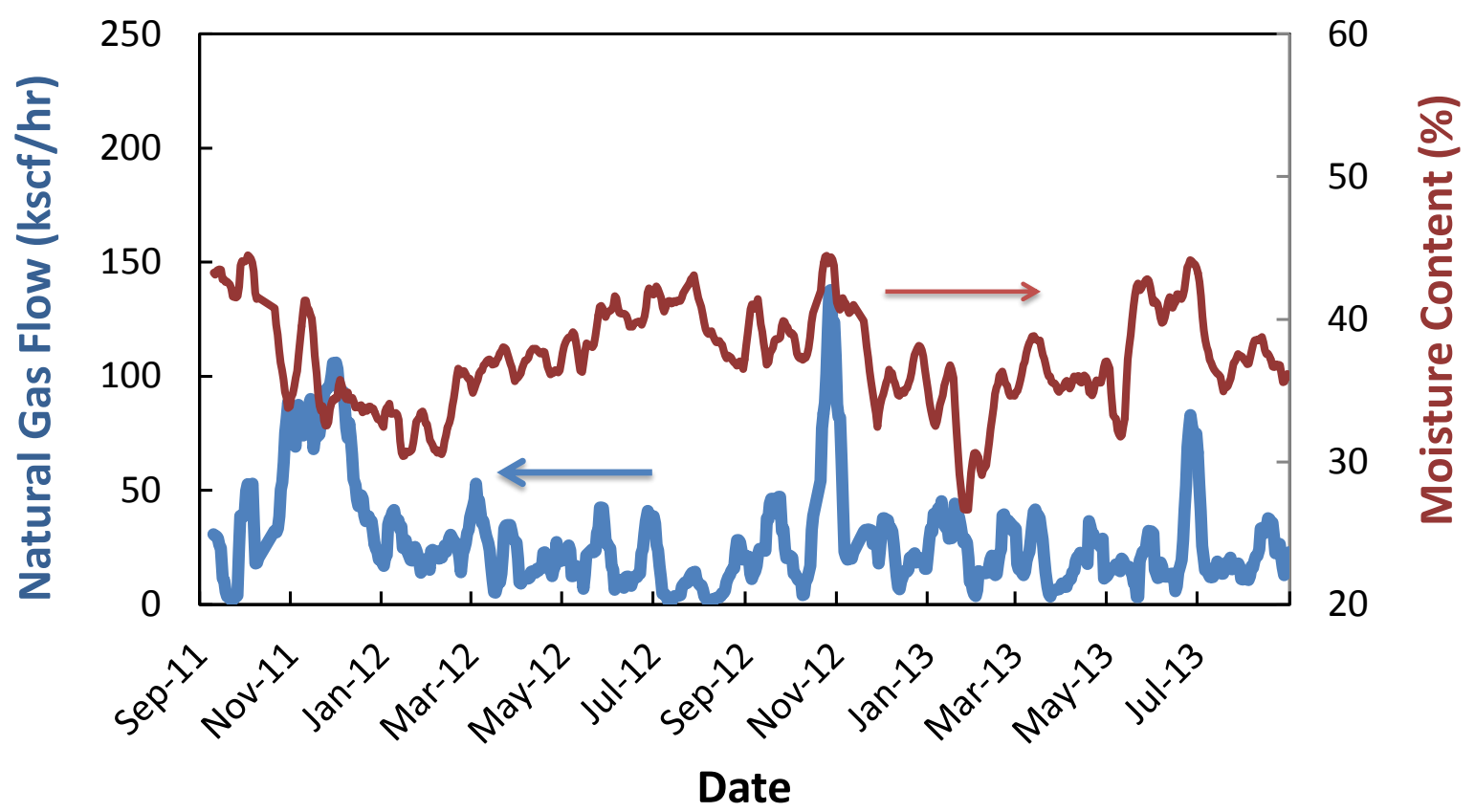

Figure A- 29. Changes of natural gas flow rate and moisture content with time for Mill A 


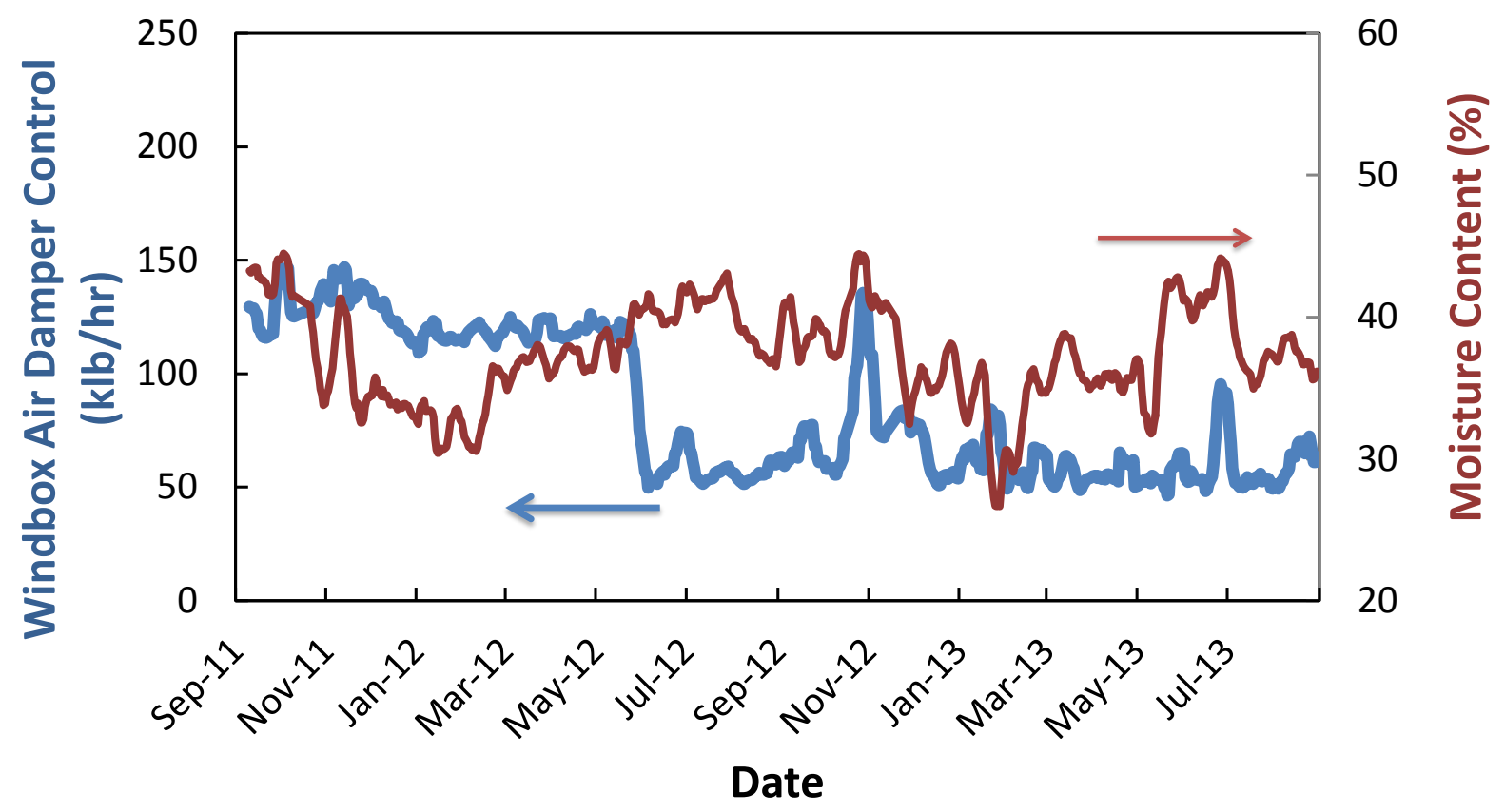

Figure A- 30. Changes of windbox air damper control and moisture content with time for Mill A

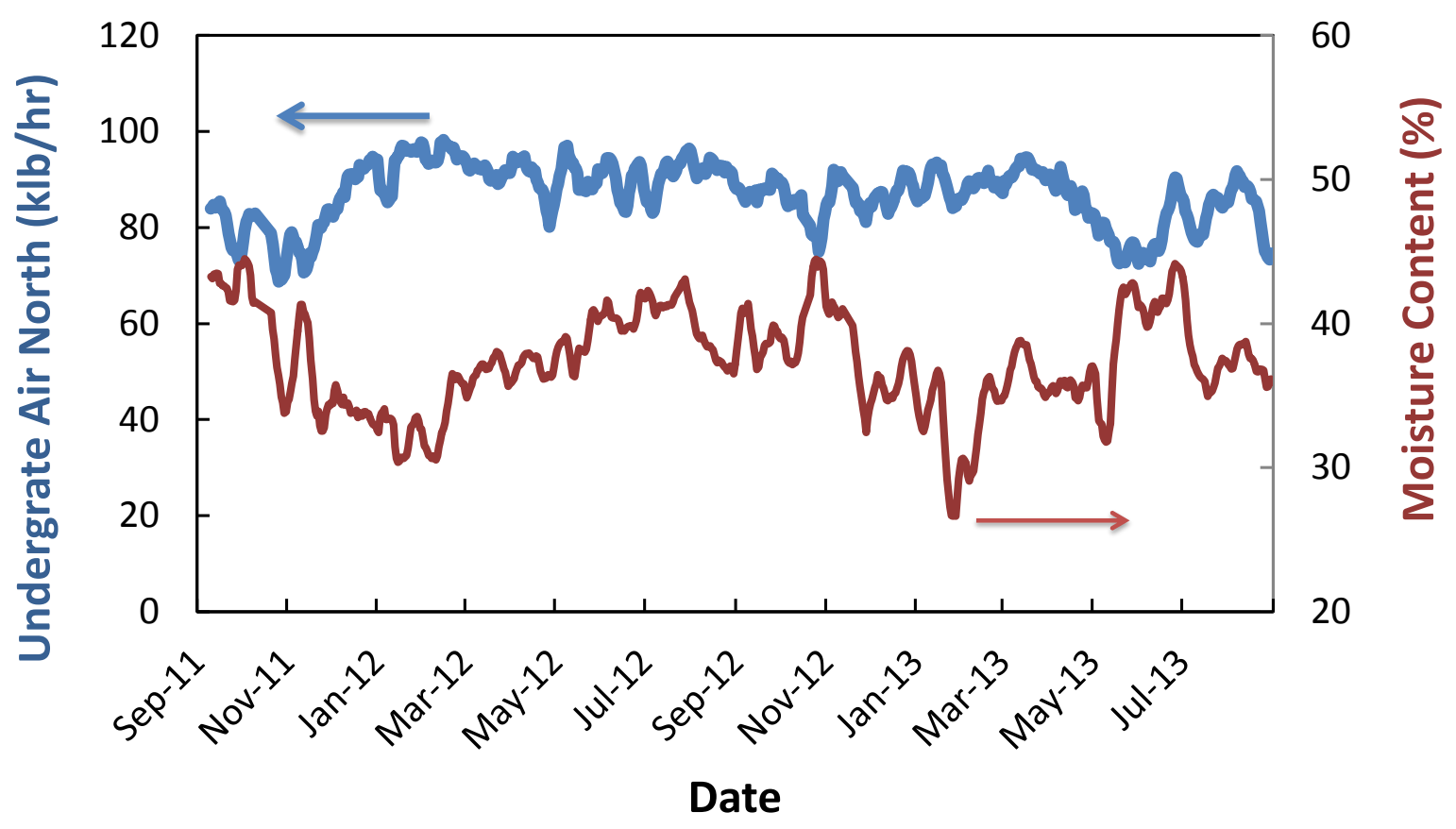

Figure A- 31. Changes of north undergrate air and moisture content with time for Mill A 


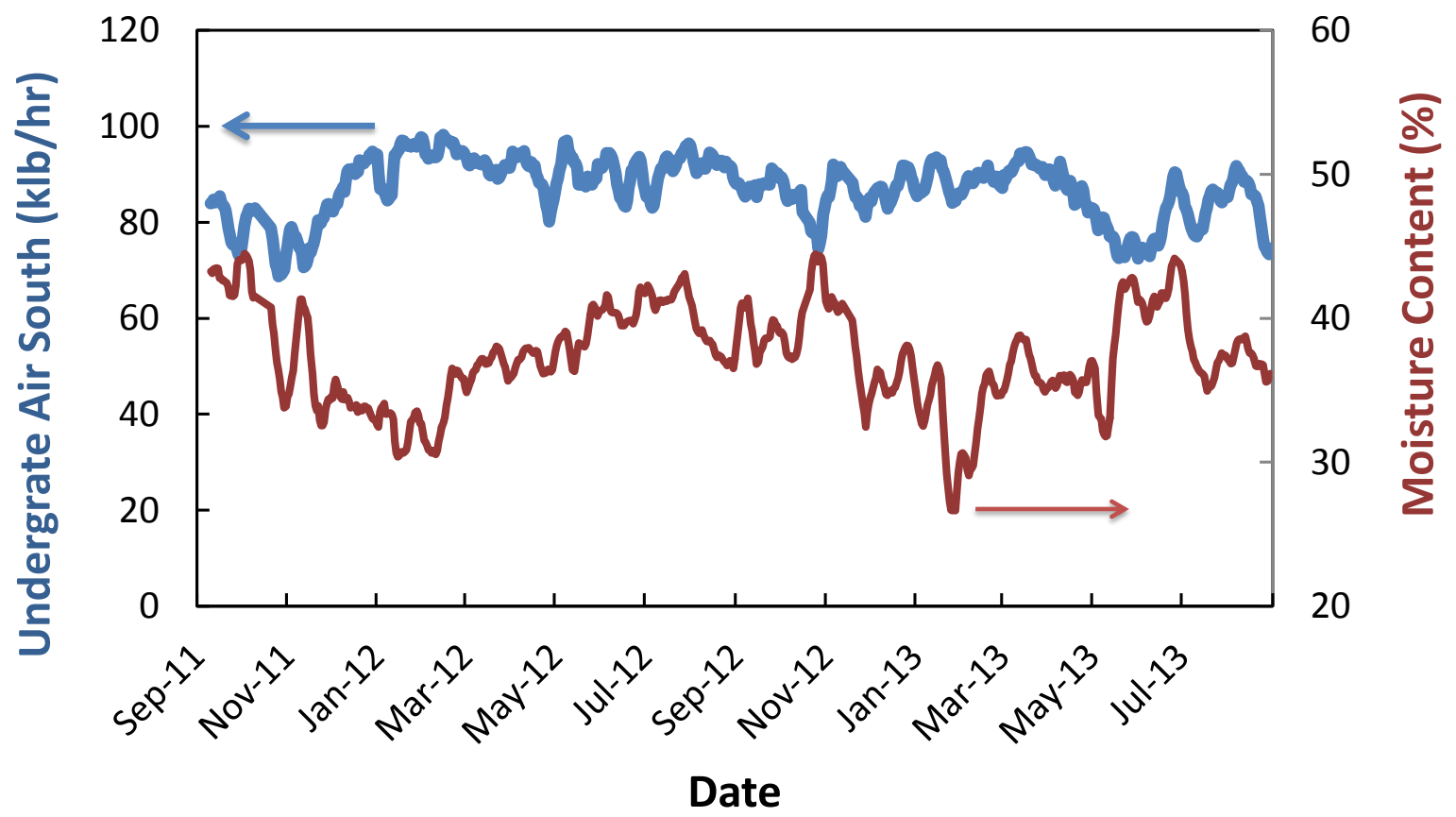

Figure A- 32. Changes of south undergrate air and moisture content with time for Mill A

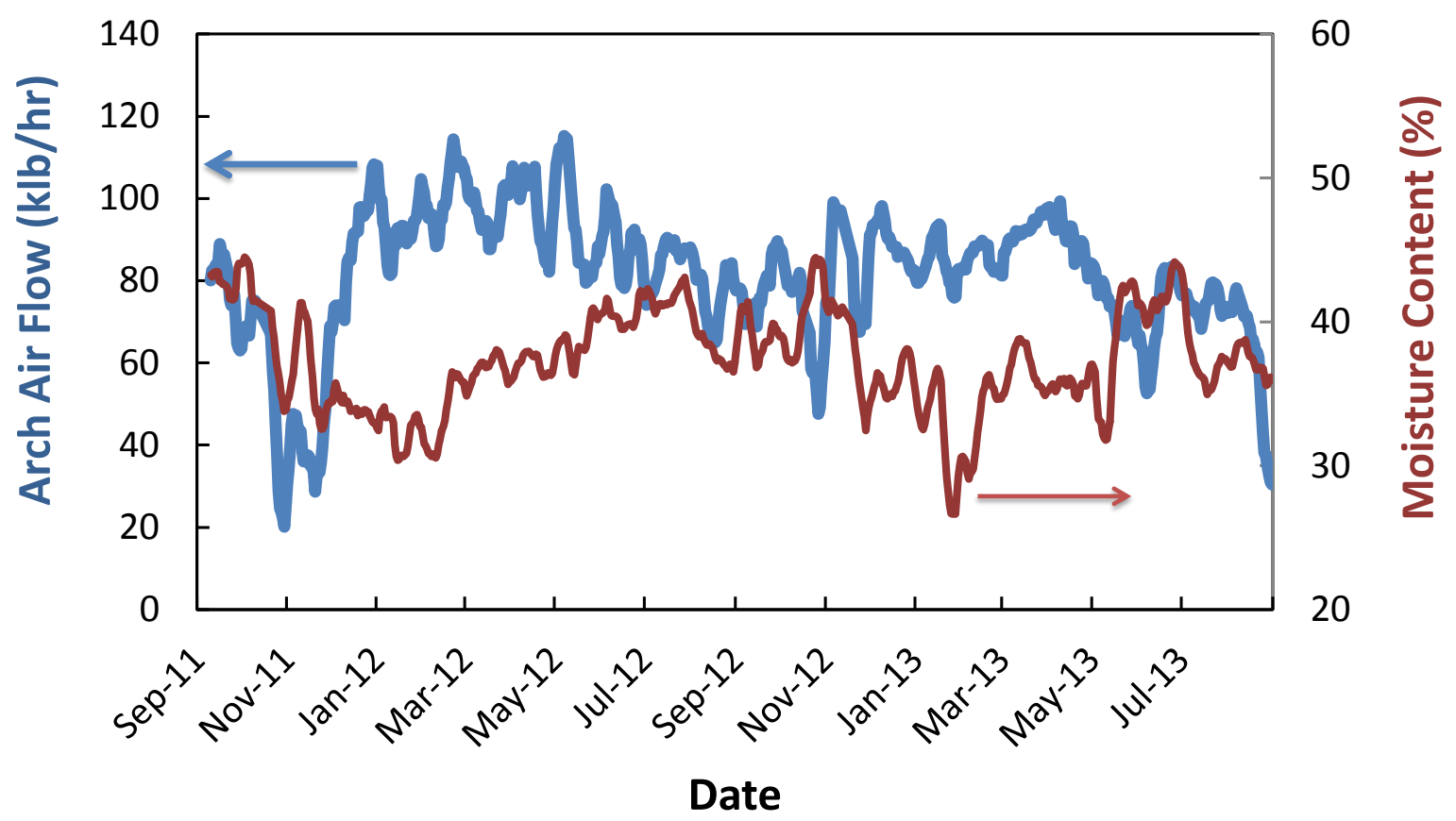

Figure A- 33. Changes of arch air flow and moisture content with time for Mill A 


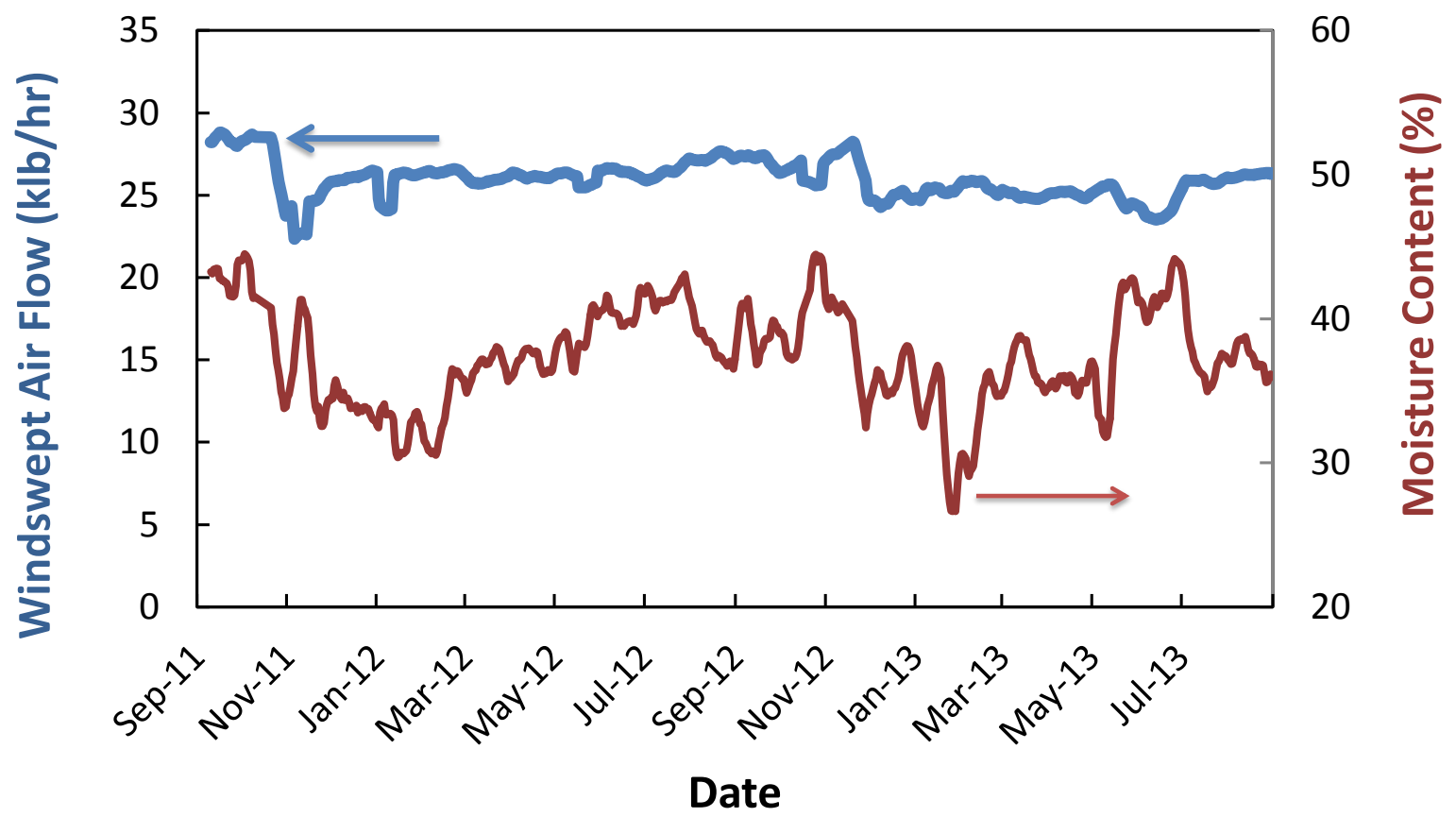

Figure A- 34. Changes of windswept air flow and moisture content with time for Mill A

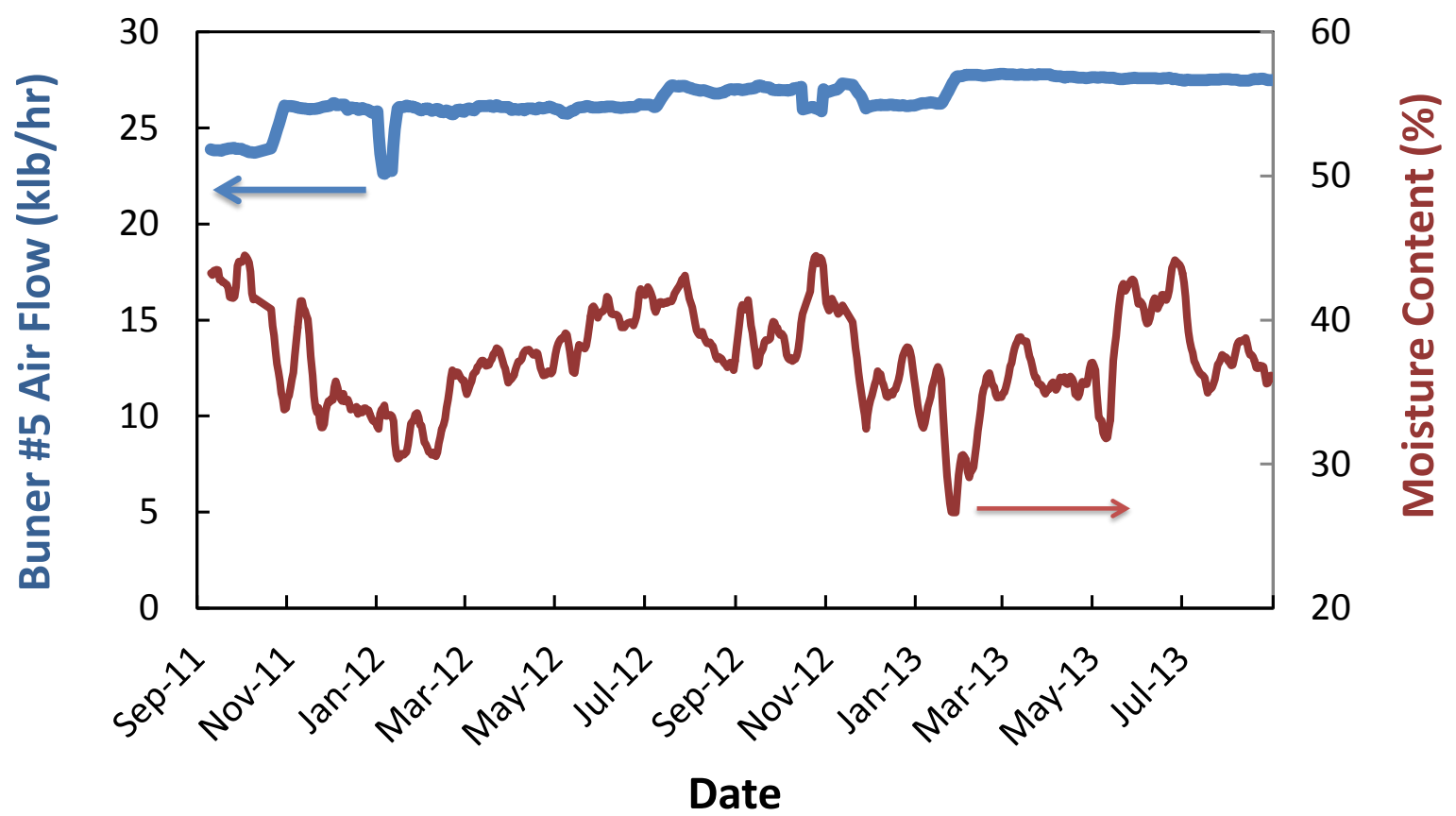

Figure A- 35. Changes of burner air flow and moisture content with time for Mill A 


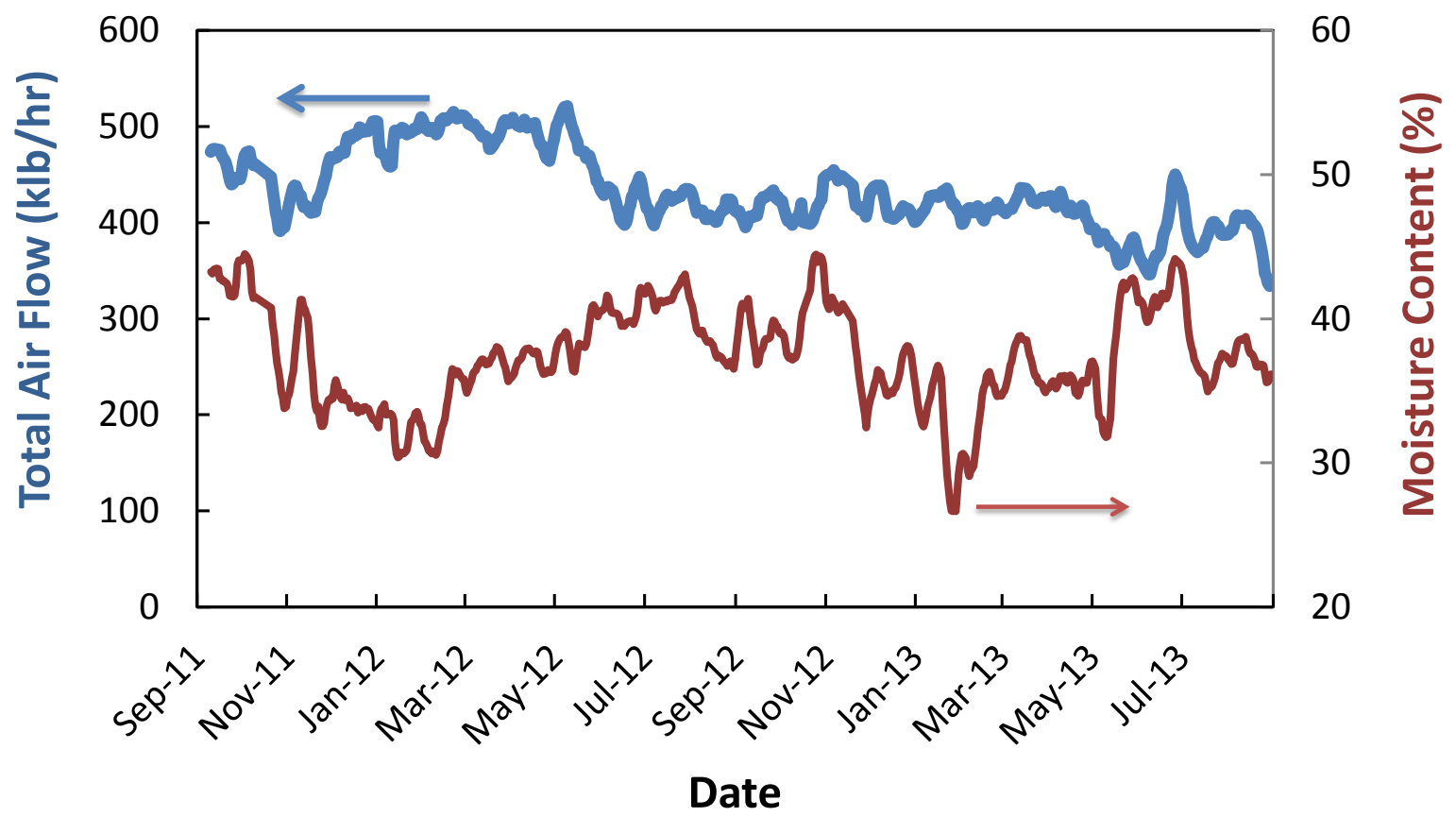

Figure A- 36. Changes of total air flow and moisture content with time for Mill A

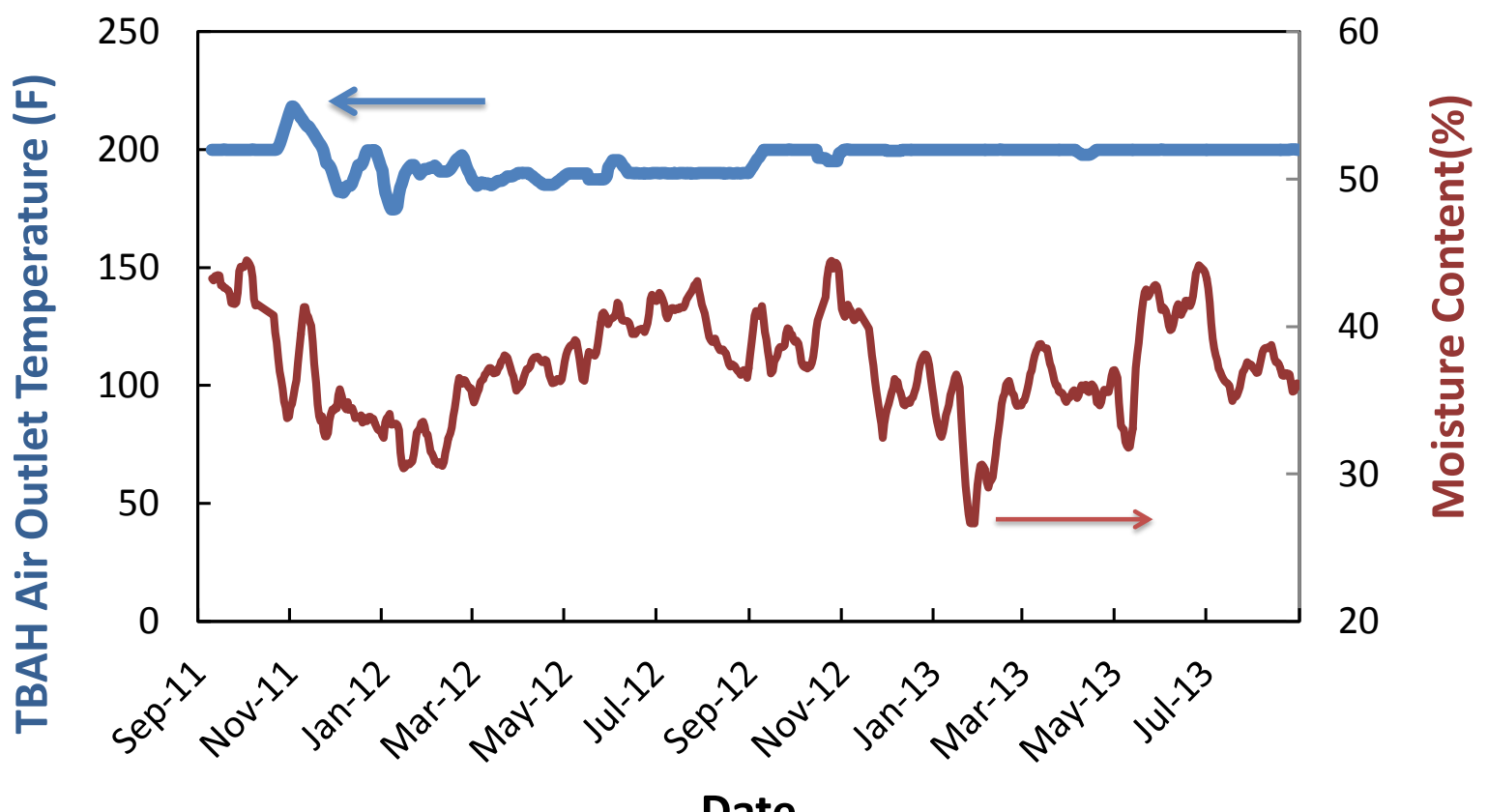

Figure A- 37. Changes of tubular air heater outlet temperature and moisture content with time for Mill A 


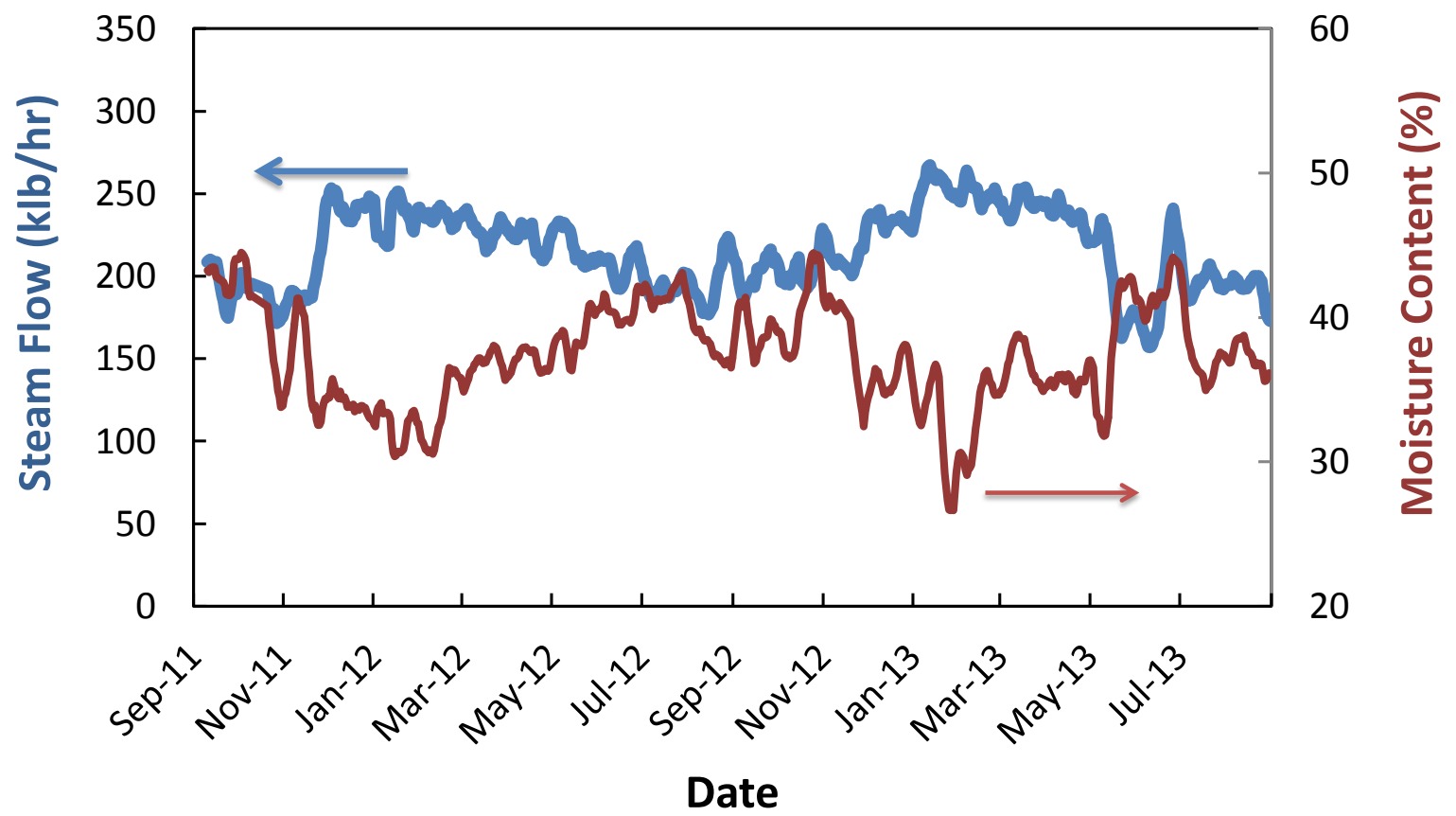

Figure A- 38. Changes of steam flow and moisture content with time for Mill A

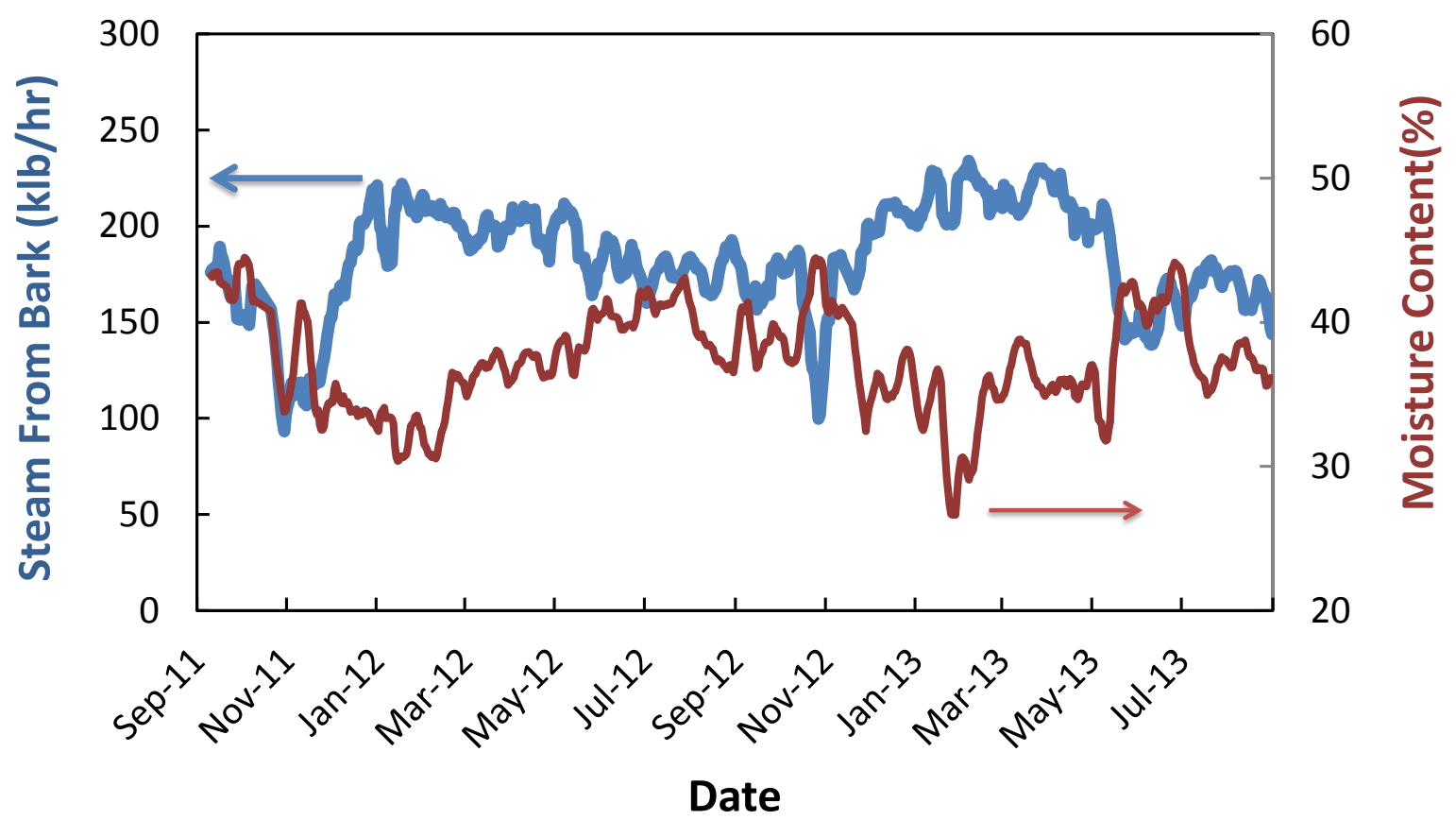

Figure A- 39. Changes of steam from bark and moisture content with time for Mill A 


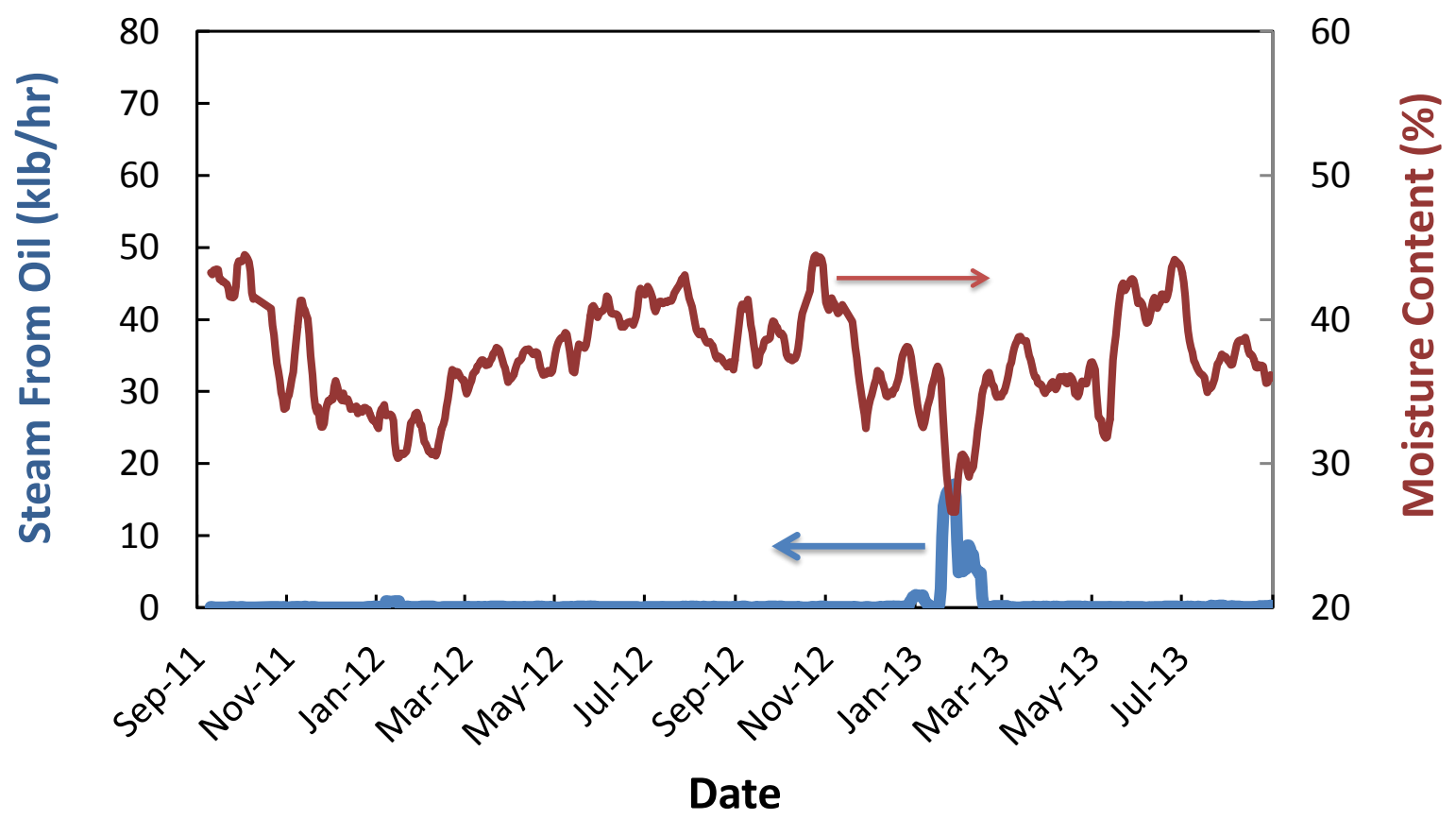

Figure A- 40. Changes of steam from oil and moisture content with time for Mill A

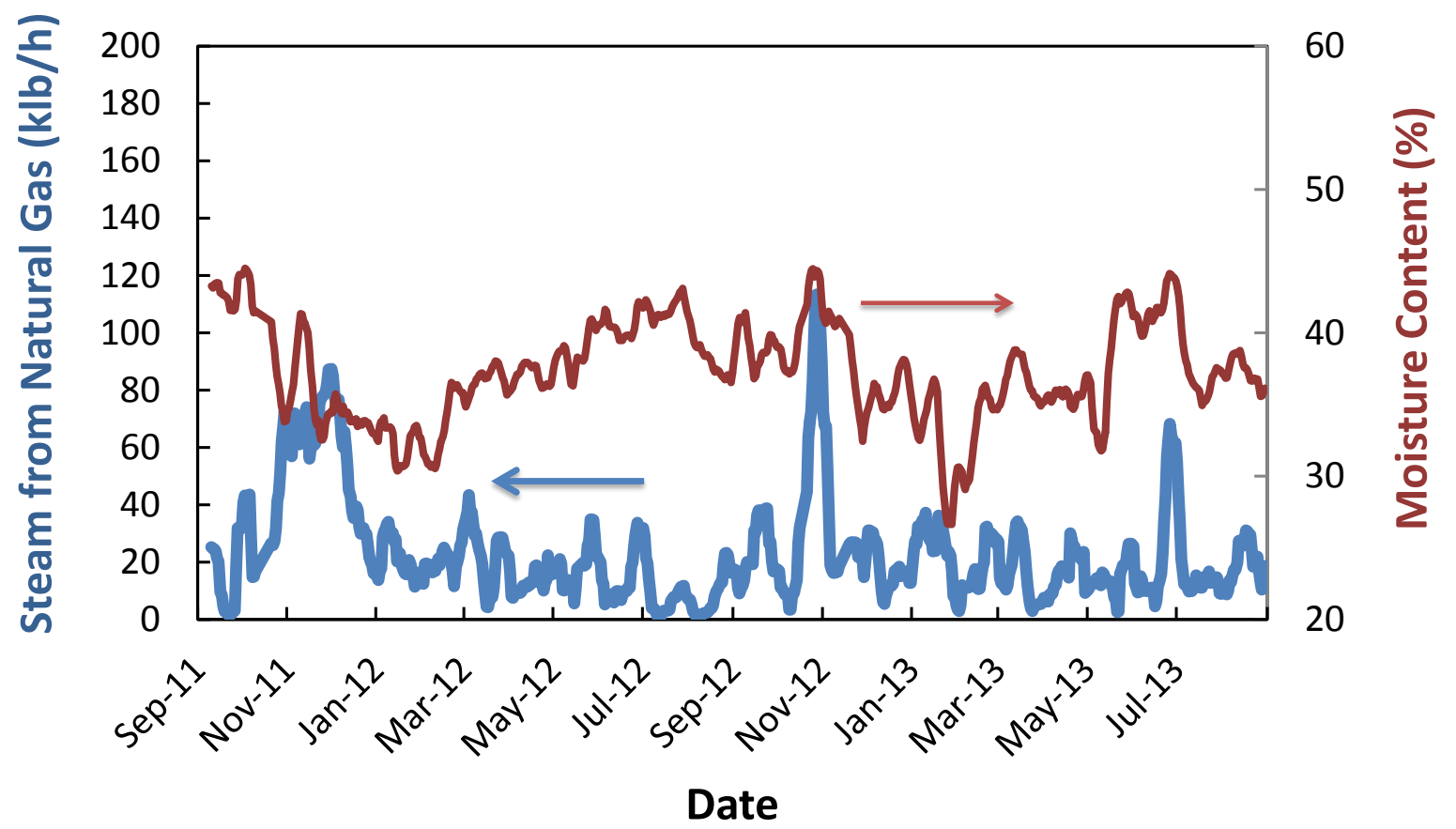

Figure A- 41. Changes of steam from natural gas and moisture content with time for Mill A 


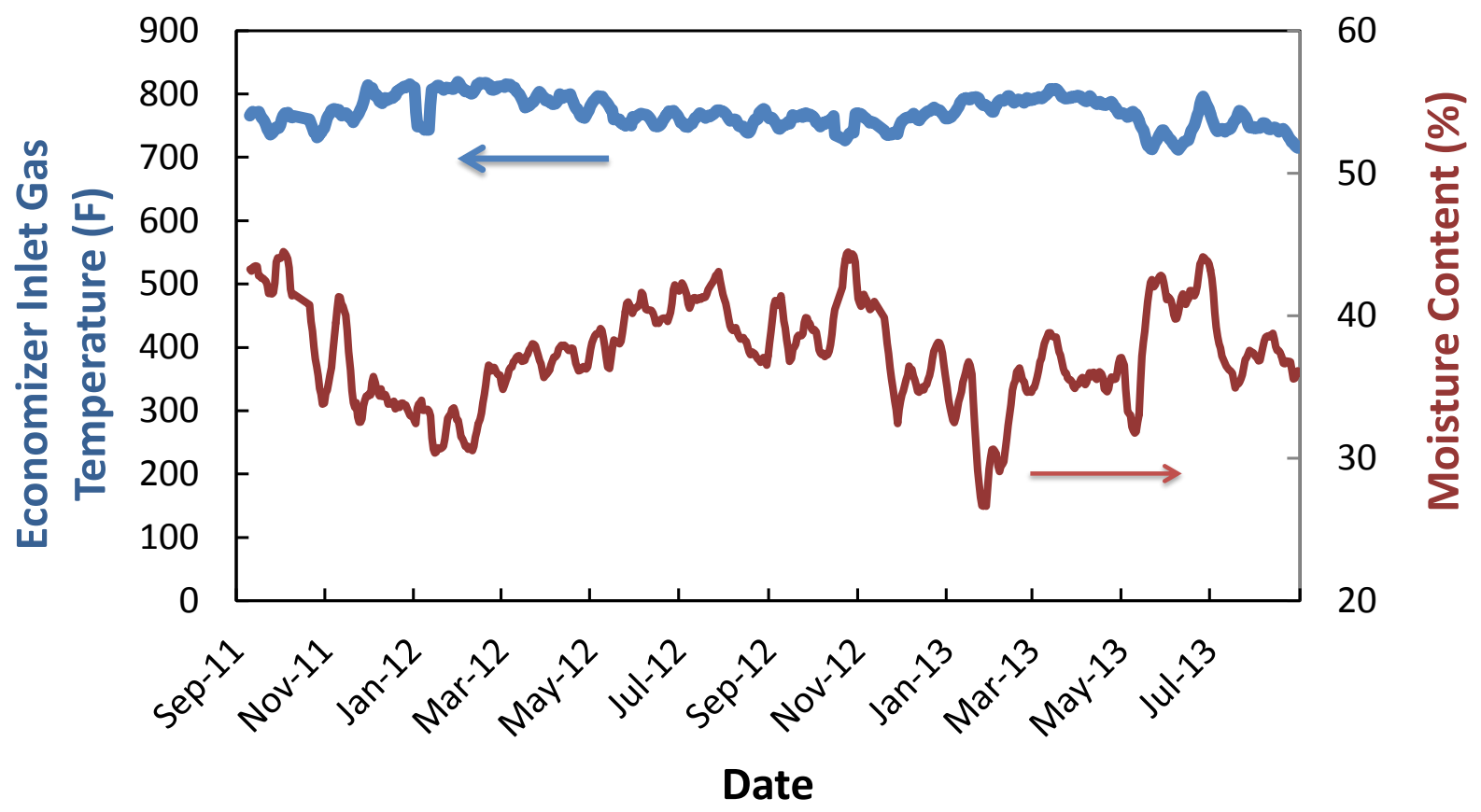

Figure A- 42. Changes of economizer inlet gas temperature and moisture content with time for Mill A

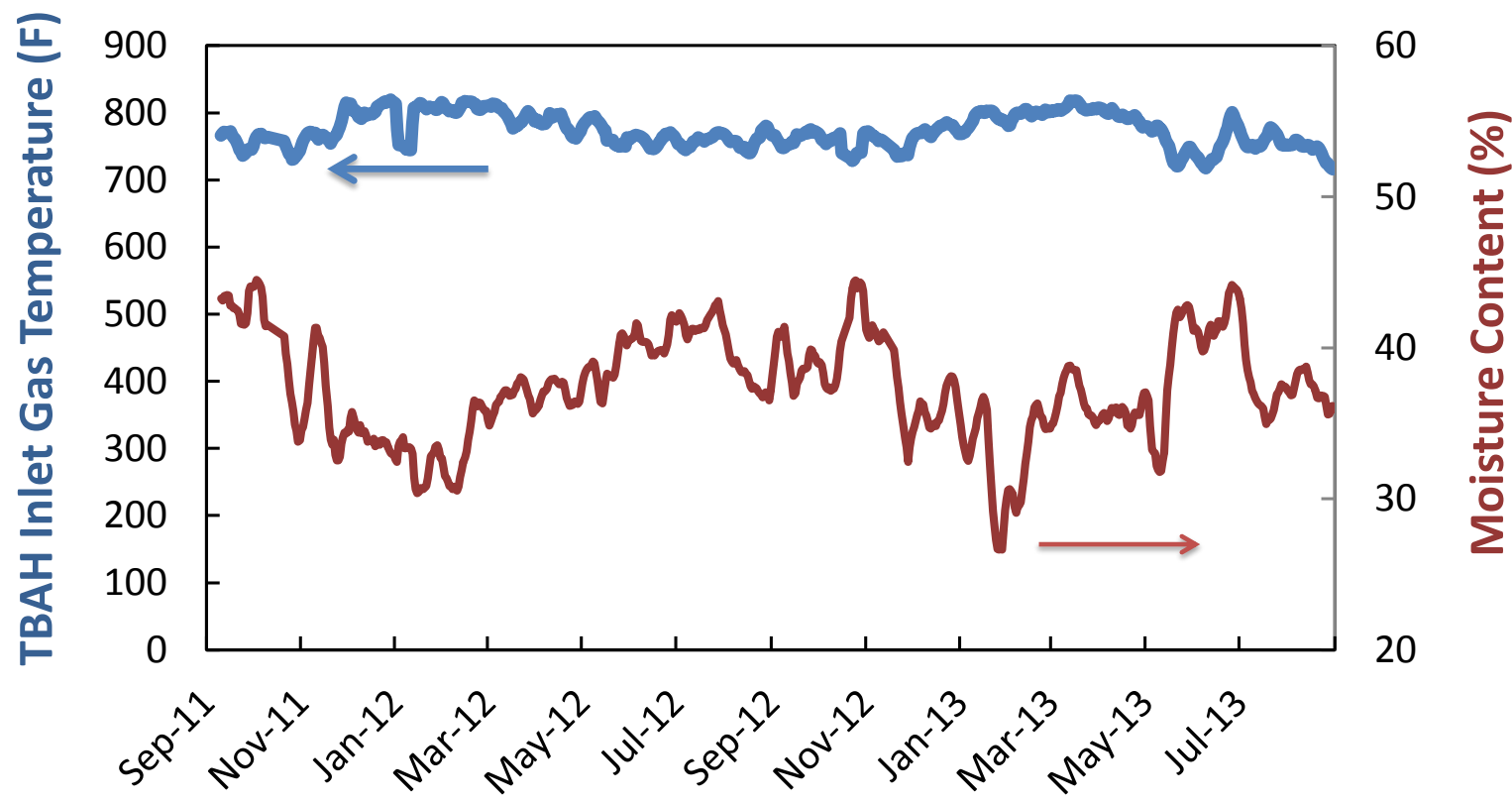

\section{Date}

Figure A- 43. Changes of tubular air heater inlet gas temperature and moisture content with time for Mill A 


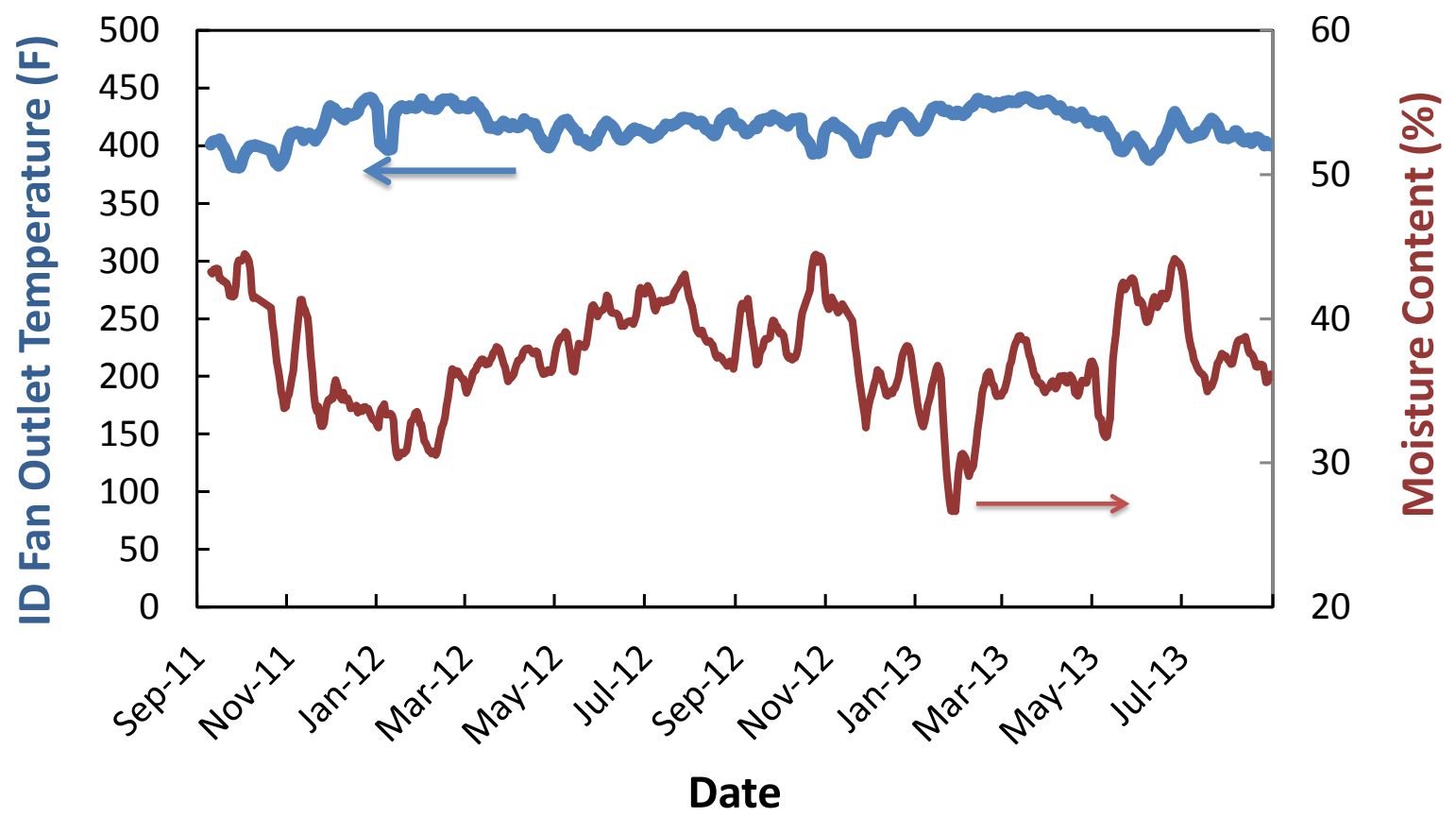

Figure A- 44. Changes of ID fan outlet temperature and moisture content with time for Mill A

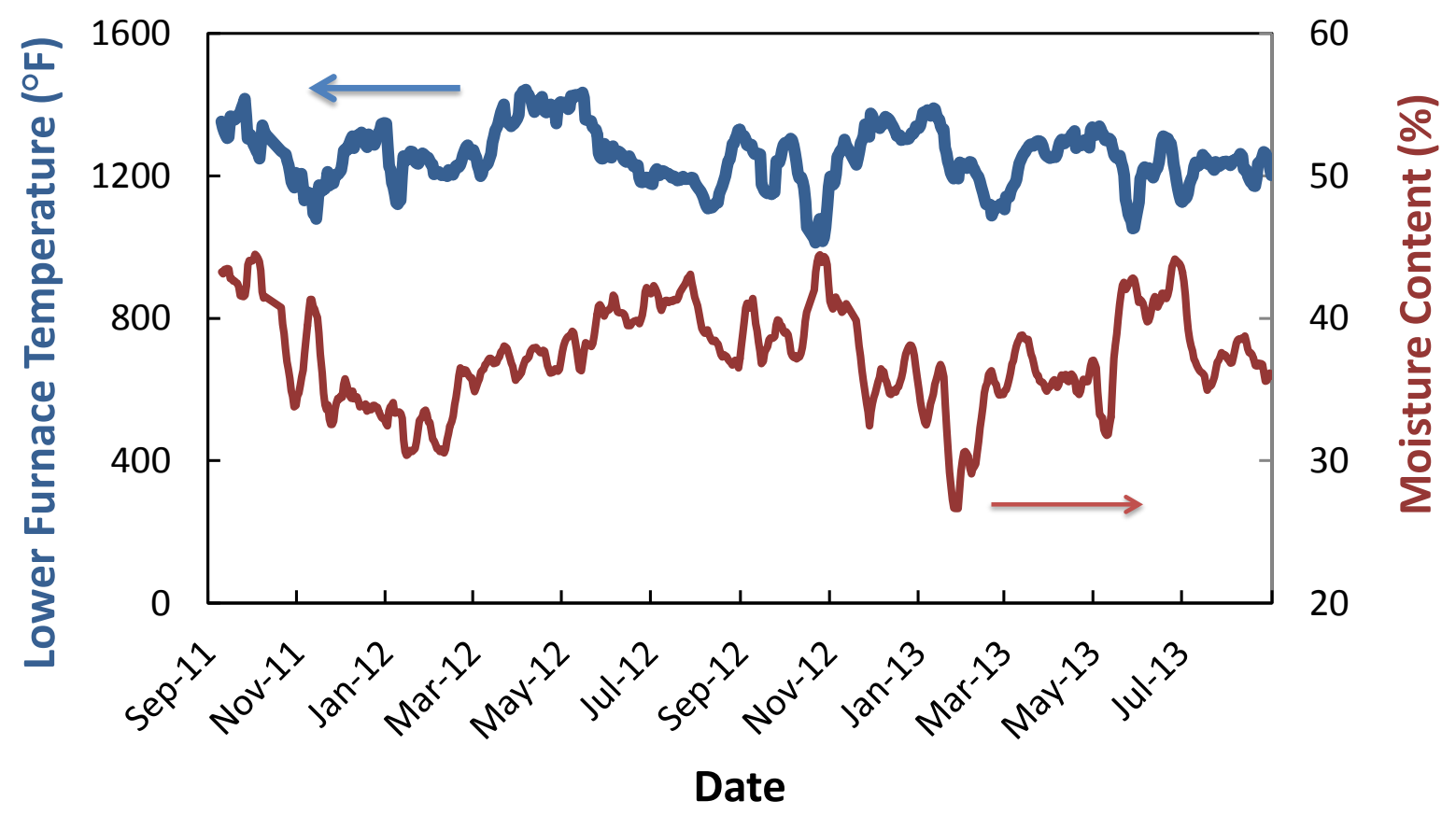

Figure A- 45. Changes of lower furnace temperature and moisture content with time for Mill A 


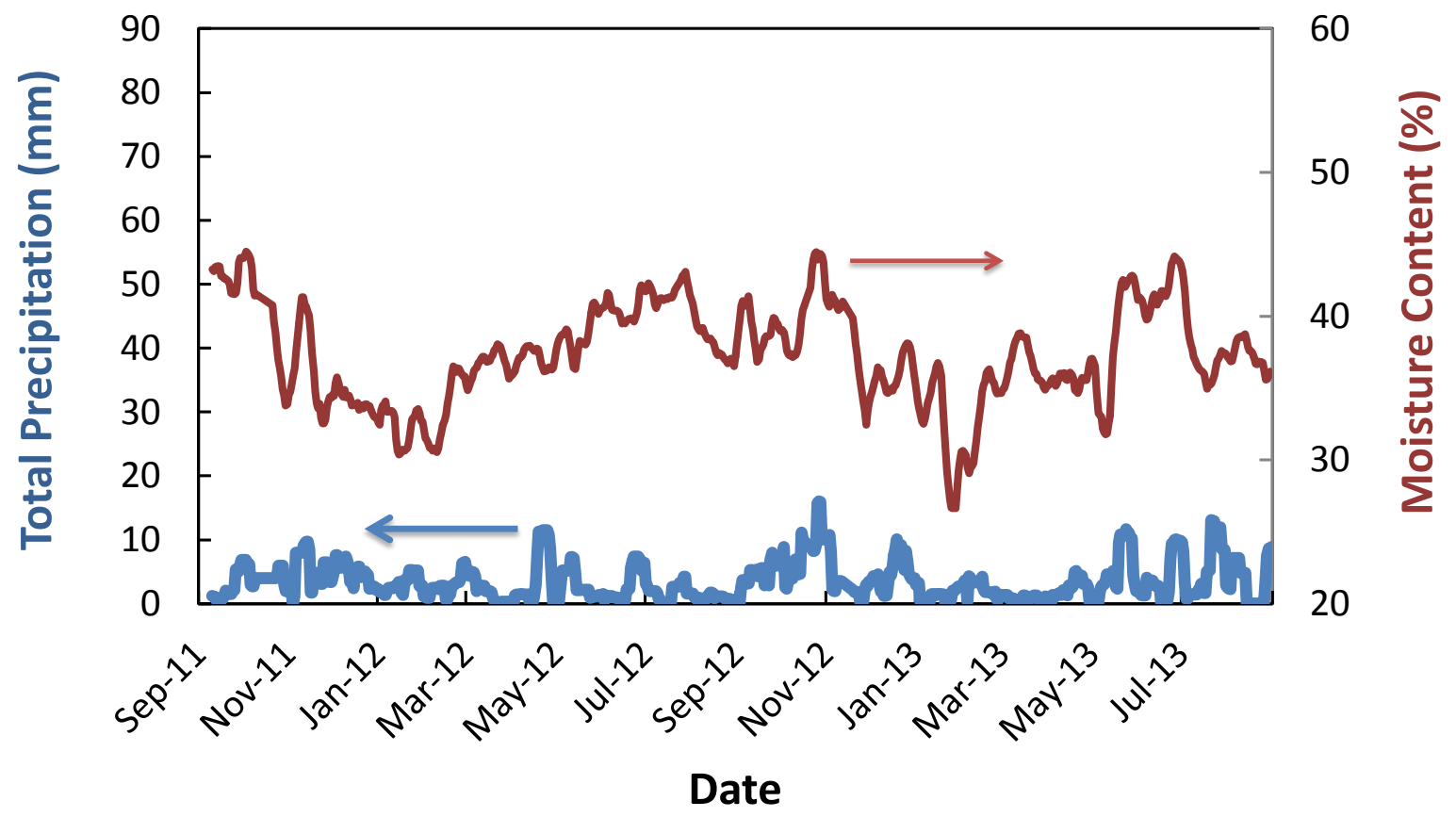

Figure A- 46. Total precipitation and changes of moisture content with time for Mill A

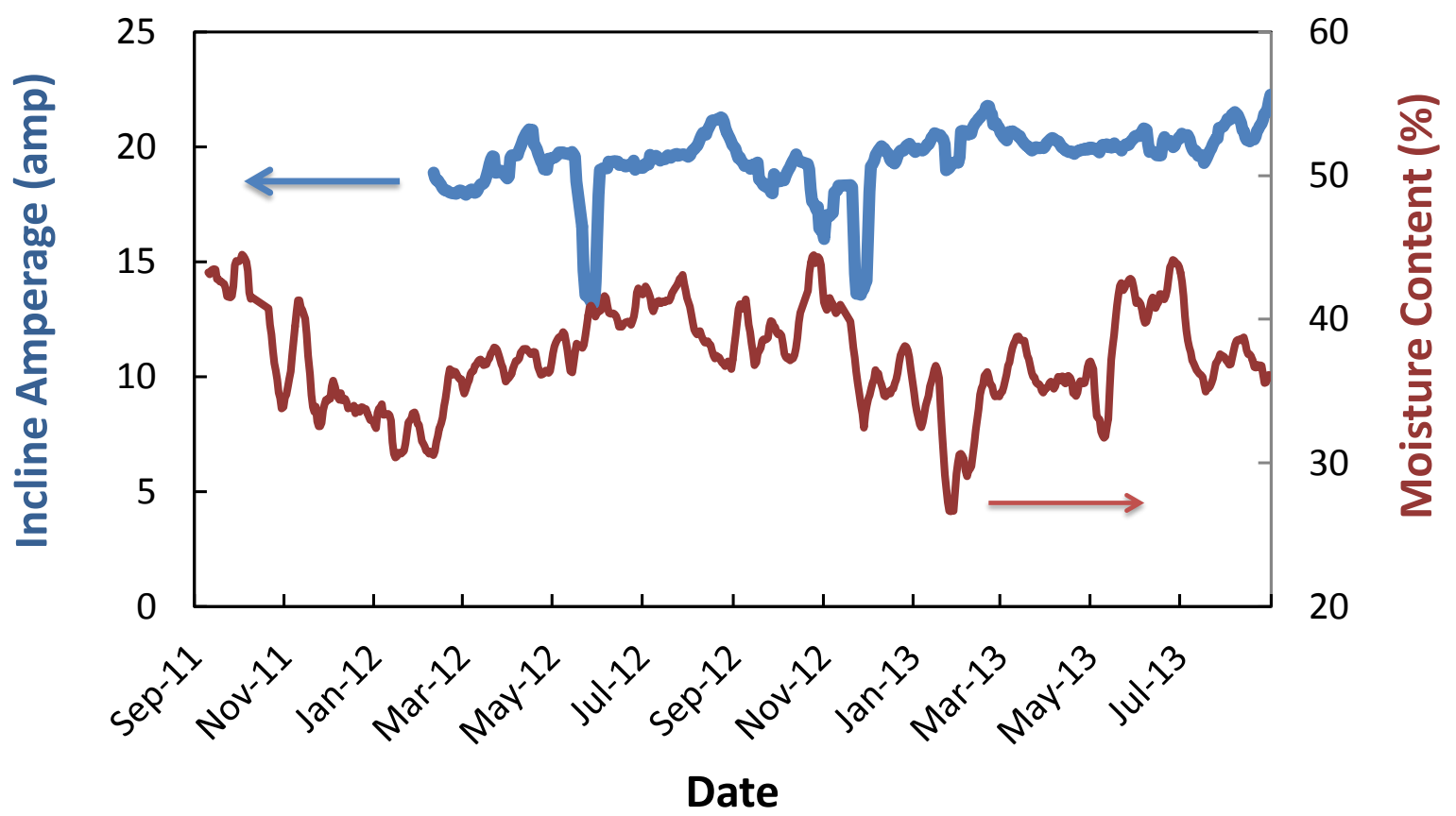

Figure A- 47. Changes of incline amperage and moisture content with time for Mill A 


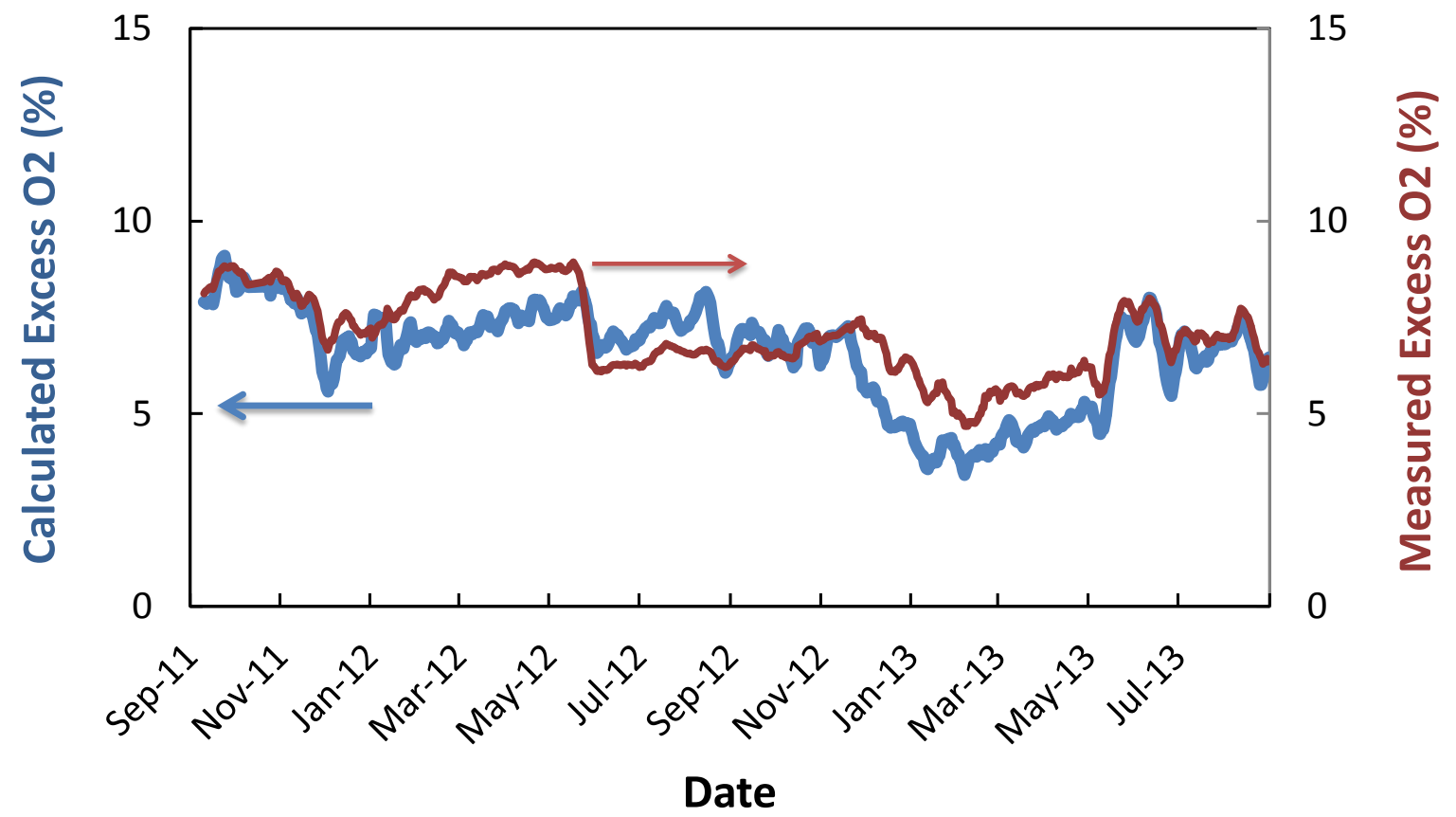

Figure A- 48. Verification of calculations by comparisong measured and calculated excess $\mathbf{O}_{2}$ 